
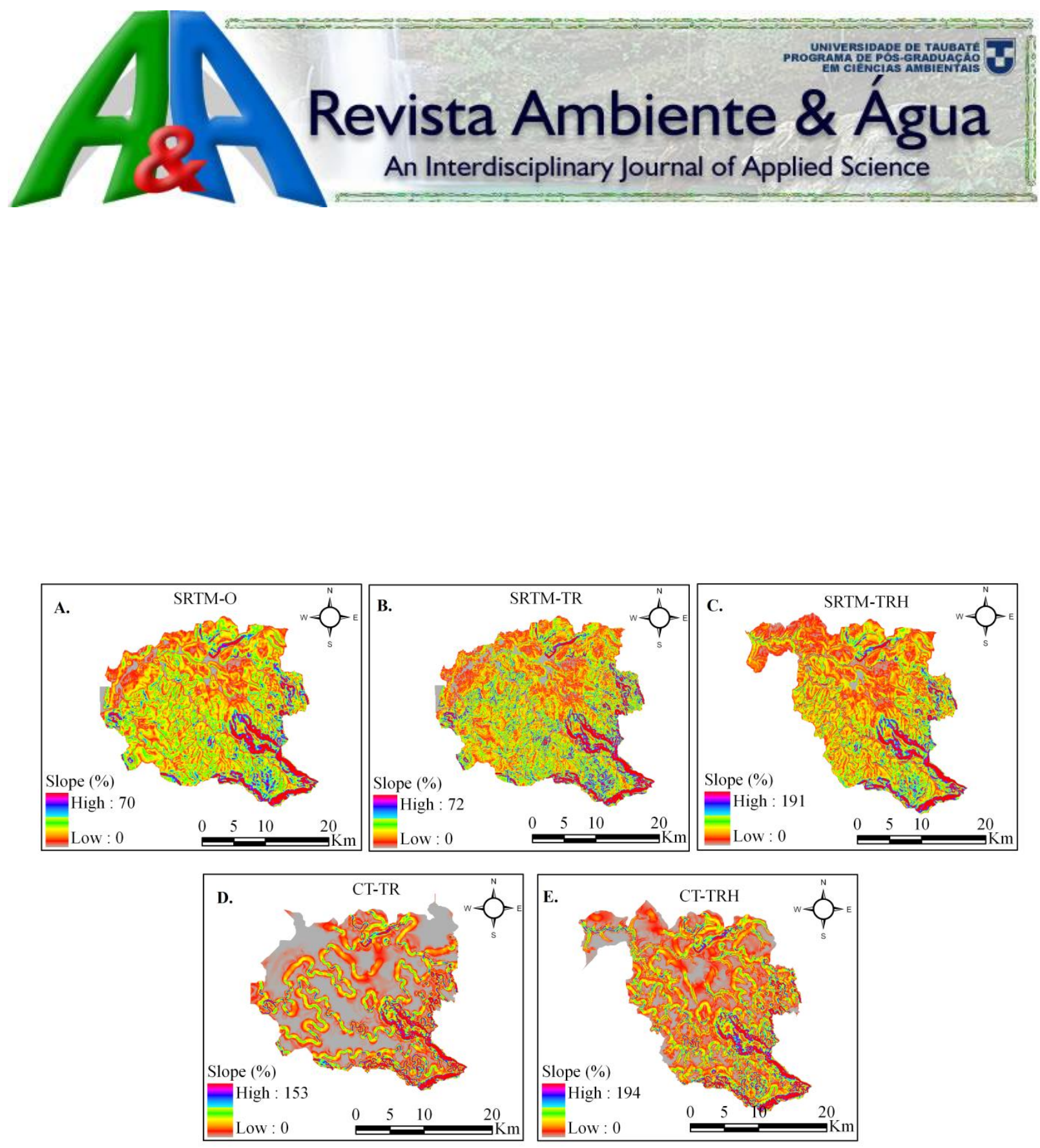

ISSN = 1980-993X (Online) 


\section{EDITORIAL BOARD}

\section{Editors}

Getulio Teixeira Batista (Emeritus Editor) Universidade de Taubaté - UNITAU, BR

Nelson Wellausen Dias (Editor-in-Chief), Fundação Instituto Brasileiro de Geografia e Estatística - IBGE, BR

Ana Aparecida da Silva Almeida

Marcelo dos Santos Targa

Andrea Giuseppe Capodaglio

Arianna Callegari

Antonio Teixeira de Matos

Apostol Tiberiu

Claudia M. dos S. Cordovil

Dar Roberts

Giordano Urbini

Gustaf Olsson

Hélio Nobile Diniz

Ignacio Morell Evangelista

János Fehér

Julio Cesar Pascale Palhares

Luis Antonio Merino

Maria Cristina Collivignarelli

Massimo Raboni

Petr Hlavínek

Richarde Marques da Silva

Stefan Stanko

Teresa Maria Reyna

Yosio Edemir Shimabukuro

Zhongliang Liu Beijing

Text Editor

Reference Editor

Peer-Reviewing Process

System Analyst

Secretary and Communication

\section{Associate Editors}

Universidade de Taubaté (UNITAU), BR

Universidade de Taubaté (UNITAU), BR

\section{Editorial Commission}

University of Pavia, ITALY

Università degli Studi di Pavia, ITALY

Universidade Federal de Viçosa (UFV), BR

University Politechnica of Bucharest, Romênia

Centro de estudos de Engenharia Rural (CEER), Lisboa, Portugal

University of California, Santa Barbara, United States

University of Insubria, Varese, Italy

Lund University, Lund, Sweden

Inst. Geológico, Sec. do Meio Amb. do Est. de SP (IG/SMA), BR

University Jaume I- Pesticides and Water Research Institute, Spain

Debrecen University, Hungary

Embrapa Pecuária Sudeste, CPPSE, São Carlos, SP, BR

Institute of Regional Medicine, National University of the Northeast, Corrientes, Argentina

University of Pavia, Depart. of Civil Engineering and Architecture, Italy

LIUC - University "Cattaneo", School of Industrial Engineering, Italy

Brno University of Technology República Tcheca

Universidade Federal da Paraíba (UFPB), BR

Slovak Technical University in Bratislava Slovak, Eslováquia

Universidad Nacional de Córdoba, Argentina

Instituto Nacional de Pesquisas Espaciais (INPE), BR

University of Technology, China

Theodore D`Alessio, FL, USA, Maria Cristina Bean, FL, USA

Liliane Castro, Bibliotecária - CRB/8-6748, Taubaté, BR

Marcelo Siqueira Targa, UNITAU, BR

Tiago dos Santos Agostinho, UNITAU, BR

Luciana Gomes de Oliveira, UNITAU, BR

\section{Library catalog entry by Liliane Castro CRB/8-6748}

Revista Ambiente \& Água - An Interdisciplinary Journal of Applied Science / Instituto de Pesquisas Ambientais em Bacias Hidrográficas. Taubaté. v. 14, n.1 (2006) - Taubaté: IPABHi, 2019.

Quadrimestral (2006 - 2013), Trimestral (2014 - 2016), Bimestral (2017), Publicação Contínua a partir de Janeiro de 2018.

Resumo em português e inglês.

ISSN 1980-993X

1. Ciências ambientais. 2. Recursos hídricos. I. Instituto de Pesquisas Ambientais em Bacias Hidrográficas.

CDD - 333.705

CDU - (03)556.18 


\section{TABLE OF CONTENTS}

\section{COVER:}

The figure shows the resulting morphometric characterization of Peixe river watershed derived from different digital elevation models generated from five elevation data sources (three from SRTM 90-meter resolution data and two from 1:100.000 scale topographic maps). Results indicated that SRTM-O, SRTMTR, and CT-TR provided the incorrect generation of hydrography in the region of the São Franciscana Depression (flat region), observed by the diversion of main river and generation of the mouth in another basin, causing significant errors in the determination of the morphometric characteristics of the basin, mainly in the drainage area and length of the main river. On the other hand, SRTM-TRH and CT-TRH presented excellent performance and are indicated for on-site study.

Source: FICHER, K. N. et al. Assessment of digital elevation models to obtain morphometric characteristics in relief transition region. Rev. Ambient. Água, Taubaté, vol. 14 n. 1, p. 1-14, 2019. doi:10.4136/ambi-agua.2280

\section{ARTICLES}

Validation of rainfall data estimated by GPM satellite on Southern Amazon region

doi:10.4136/ambi-agua.2249

01

Luiz Octavio Fabricio dos Santos; Carlos Alexandre Santos Querino;

Juliane Kayse Albuquerque da Silva Querino; Altemar Lopes Pedreira Junior;

Aryanne Resende de MeloMoura; Nadja Gomes Machado; Marcelo Sacardi Biudes

Histopathological and hematological biomarkers in tambaqui Colossoma macropomum (Cuvier, 1816) from an environmental protection area of Maranhão, Brazil

02 doi:10.4136/ambi-agua.2266

Jonatas da Silva Castro; Camilla Fernanda Lima Sodré; Caroline Bogéa Souza;

Débora Batista Pinheiro Sousa; Raimunda Nonata Fortes Carvalho Neta

Defining environmental conservation levels considering anthropic activity in the Uberaba River Basin protected area

03 doi:10.4136/ambi-agua.2279

Allita Rezende dos Santos; Renato Carneiro Fernandes da Silva; Leonardo Campos de Assis; Frederico Fábio Mauad

Physico-chemical variability and heavy metal pollution of surface sediment in a non-channeled section of Dilúvio Stream (Southern Brazil) and the influence of channeled section in sediment pollution

doi:10.4136/ambi-agua.2285

Pedro Alexandre Sodrzeieski; Leonardo Capeleto de Andrade; Tales Tiecher;

Flávio Anastácio de Oliveira Camargo

Losses of soil, water, organic carbon and nutrients caused by water erosion in different crops and natural savannah in the northern Amazon

05 doi:10.4136/ambi-agua.2126

Fernando Gomes de Souza; Valdinar Ferreira Melo; Wellington Farias Araújo;

Thiago Henrique de Castro Araújo

Using the pollutant load concept to assess water quality in an urban river: the case of Carahá River (Lages, Brazil)

06 doi:10.4136/ambi-agua.2252

Jessica Quinatto; Natan Liz De Nale Zambelli; Diego Hoefling Souza; Sílvio Luís Rafaeli Neto; Josiane Teresinha Cardoso; Everton Skoronski 
Baker's yeast- $\mathrm{MnO}_{2}$ composites as biosorbent for Malachite green: An ecofriendly approach for dye removal from aqueous solution

Bruna Assis Paim dos Santos; Aline Silva Cossolin; Hélen Cristina Oliveira dos Reis; Ketinny Camargo de Castro; Evanleide Rodrigues da Silva; Gabriele de Menezes Pereira; Paulo Teixeira de Sousa Junior; Evandro Luiz Dall'Oglio; Leonardo Gomes de Vasconcelos; Eduardo Beraldo de Morais

Wastewater treatment using adsorption process in column for agricultural purposes

08 doi:10.4136/ambi-agua.2178

Flávia Rhuana Pereira Sales; Reynaldo Borges Galvão Serra; Gesivaldo Jesus Alves de Figueirêdo; Paulo Henrique Almeida da Hora; Antonio Cícero de Sousa

Quantification study of Azithromycin drugs in soil, by the infrared technique with Fourier Transform (IFTR)

09 doi:10.4136/ambi-agua.2268

Amanda Carvalho Miranda; Rogerio Bonette Klepa; Thiago Michel Brito de Farias; José Carlos Curvelo Santana

\section{Assessment of digital elevation models to obtain morphometric characteristics in relief transition region}

Kevin Nunes Ficher; Donizete dos Reis Pereira; Josiane SilvaOliveira; André Quintão de Almeida; Eduardo Morgan Uliana

Spatial-temporal analysis of the surface water quality of the Pará River Basin through statistical techniques

11 doi:10.4136/ambi-agua.2322

Josiani Cordova de Oliveira; Kelly Prado Maia; Nara Linhares Borges de Castro;

Sílvia Maria Alves Corrêa Oliveira

High concentrations of toxic metals in water consumed by the Maxakali indigenous community in Brazil

Eliseu Miranda de Assis; Maicon Junior dos Santos Souza; Márcia Cristina da Silva Faria;

Jairo Lisboa Rodrigues; Anderson Garcez; Cleide Aparecida Bomfeti;Nêmora Tregnago Barcellos

Canonical analysis of climatic factors associated with the quality characteristics of drinking water of a city in São Paulo State

13 doi:10.4136/ambi-agua.2219

Sérgio Augusto Rodrigues; Paulo André de Oliveira; Ricardo Ghantous Cervi; Lilian Cristina Trevizan; Carlos Roberto Padovani

Potentially toxic metals in lotic systems with aptitude for aquaculture at the watershed Mantaro River, Peru

María Custodio; Fernán Cosme Chanamé Zapata; Danny Julio Cruz Flores; Wilfredo Bulege Gutiérrez

Sewage sludge compost in zoysia grass sod production 


\begin{tabular}{|} 
Ambiente \& Água - An Interdisciplinary Journal of Applied Science \\
ISSN 1980-993X - doi:10.4136/1980-993X \\
www.ambi-agua.net \\
E-mail: ambi.agua@gmail.com
\end{tabular}

\title{
Validation of rainfall data estimated by GPM satellite on Southern Amazon region
}

\author{
ARTICLES doi:10.4136/ambi-agua.2249 \\ Received: 04 Mar. 2018; Accepted: 01 Nov. 2018
}

\begin{abstract}
Luiz Octavio Fabricio dos Santos ${ }^{1}$; Carlos Alexandre Santos Querino ${ }^{2 *}$; Juliane Kayse Albuquerque da Silva Querino ${ }^{2}$; Altemar Lopes Pedreira Junior ${ }^{1 D}$; Aryanne Resende de Melo Moura1 ${ }^{1 D}$; Nadja Gomes Machado ${ }^{3}$; Marcelo Sacardi Biudes 4

\author{
${ }^{1}$ Universidade Federal do Amazonas (UFAM), Humaitá, Amazonas, Brasil \\ Instituto de Educação, Agricultura e Ambiente (IEAA). E-mail: luiz_octavio19@outlook.com, \\ merklein3@hotmail.com, aryanneresende.mm@gmail.com \\ ${ }^{2}$ Universidade Federal do Amazonas (UFAM), Humaitá, Amazonas, Brasil \\ Instituto de Educação, Agricultura e Ambiente (IEAA). Programa de Pós-graduação em Ciências Ambientais. \\ E-mail: carlosquerino@ufam.edu.br,julianekayse@hotmail.com \\ ${ }^{3}$ Instituto Federal de Educação, Ciência e Tecnologia de Mato Grosso (IFMT), Cuiabá, MT, Brasil \\ Departamento de Ensino. Programa de Pós-Graduação em Física Ambiental (PPGFA). \\ E-mail: nadja.machado@blv.ifmt.edu.br \\ ${ }^{4}$ Universidade Federal de Mato Grosso (UFMT), Cuiabá, MT, Brasil \\ Instituto de Física. Programa de Pós-Graduação em Física Ambiental (PPGFA). E-mail: marcelo@ fisica.ufmt.br \\ *Corresponding author
}

\begin{abstract}
Rainfall is a meteorological variable of great importance for hydric balance and for weather studies. Rainfall estimation, carried out by satellites, has increased the climatological dataset related to precipitation. However, the accuracy of these data is questionable. This paper aimed to validate the estimates done by the Global Precipitation Measurement (GPM) satellite for the mesoregion of Southern Amazonas State, Brazil. The surface data were collected by the National Water Agency - ANA and National Institute of Meteorology - INMET, and is available at both institutions' websites. The satellite precipitation data were accessed directly from the NASA webpage. Statistical analysis of Pearson correlation was used, as well as the Willmott's "d" index and errors from the MAE (Mean Absolute Error) and RMSE (Root Mean Square Error). The GPM satellite satisfactorily estimated the precipitation, once it had correlations above $73 \%$ and high Willmott coefficients (between 0.86 and 0.97). The MAE and RMSE showed values that varied from $36.50 \mathrm{~mm}$ to $72.49 \mathrm{~mm}$ and $13.81 \mathrm{~mm}$ to $71.76 \mathrm{~mm}$, respectively. Seasonal rain variations are represented accordingly. In some cases, either an underestimation or an overestimation of the rain data was observed. In the yearly totals, a high rate of similarity between the estimated and measured values was observed. We concluded that the GPM-based multi-satellite precipitation estimates can be used, even though they are not $100 \%$ reliable. However, adjustments in calibration for the region are necessary and recommended.
\end{abstract}

Keywords: remote sensing, statistical analysis, weather monitoring. 


\section{Validação dos dados de precipitação estimados pelo satélite GPM na região sul do Amazonas}

\section{RESUMO}

A precipitação é a variável meteorológica de maior importância para o balanço hídrico e estudo do clima. As estimativas de precipitação feitas por satélites têm contribuído para aumentar o conjunto de dados climatológicos relacionados a chuva. Entretanto, o nível de confiança destes dados é questionável. O objetivo deste artigo foi validar os dados estimados pelo satélite Global Precipitation Measurement (GPM) para a mesorregião Sul do Estado do Amazonas, Brasil. Os dados de superfície foram coletados da Agência Nacional de Águas (ANA) e do Instituto Nacional de Meteorologia (INMET), disponibilizados no site de ambas as instituições. Os dados estimados foram acessados diretamente no site da NASA. Foi utilizada análise estatística de correlação de Pearson, índice "d" de Willmott, e erros Erro Médio Absoluto (MAE) e Erro Médio Quadrático da Raiz (RMSE). O Satélite GPM estimou de maneira satisfatória a precipitação, pois obteve correlações superiores a 73\% e altos coeficiente de Wilmott (entre 0.86 a 0.97). O MAE e RMSE apresentaram valores que variaram de $(36.50 \mathrm{~mm}$ a $72.49 \mathrm{~mm})$ e $(13.81 \mathrm{~mm}$ a $71.76 \mathrm{~mm})$, respectivamente. As variações sazonais da chuva foram bem representadas. Em alguns casos, foi observada subestimação ou superestimação dos dados de chuva. Nos totais anuais, observou-se uma alta taxa de similaridade entre os valores estimados e medidos. Conclui-se que as estimativas do GPM podem ser utilizadas, mas não com 100\% de confiabilidade. Dessa maneira, é necessário que haja uma calibração para a região local.

Palavras-chave: análise estatística, monitoramento climático, sensoriamento remoto.

\section{INTRODUCTION}

Amazonas is one of the states with the lower indexes of deforested area in the Legal Amazon region. However, the Southern Amazonas region has been consolidating as a new expansion area for agriculture and cattle raising and, consequently, has the largest deforested area in the state (Macedo and Teixeira, 2009). Deforestation provokes microclimatic changes that may cause alterations in the functioning of the Amazon rainforest dynamics. These changes cause a gradual process of savanization due to alterations in the hydrologic cycle of this ecosystem (Marengo and Betts, 2011).

The hydrological cycle in a certain region is directly related with its topography, geology, physical mechanisms and the climate, of which precipitation (Ppt) is the most important phenomenon. Ppt is considered as a preponderant system that modifies environmental dynamics and is a variant of environmental balance and natural processes. (Girão and Corrêa, 2004). Thus, characterizing Ppt over a region enables better planning for agricultural practices, soil structure conservation, construction (drainage channels and dams), weather forecasting and the use of hydric resources (Reis, 2014).

To monitor rainfall, it is necessary to use specific tools (pluviometers) to measure it in loco. However, the lack of Ppt data in the Southern Amazonas region generates a demand for the use of alternative measures such as, for instance, the use of remote sensing by satellites. This information is extremely important for regions with high rainfall rates, since they may contribute to rainfall data collection and analysis.

Remote sensing is a powerful tool because it offers a wide range of information. Thus, it is possible to monitor energy partition and space-time distribution on a regional scale. In general, rainfall estimates by remote sensing occur using sensors that are attached to the satellite, such as Global Precipitation Measurement (GPM). GPM is projected to unify and 
improve rainfall estimates from microwave sensors. The GPM satellite was built to replace the Tropical Rainfall Measurement Mission (TRMM), with the aim of providing a new generation of remote observations of rain and snow (Hou et al., 2014).

Recently studies have compared the performances of the TRMM and GPM satellites. In both cases, the Ppt estimates have shown quality, even at a regional or global scale. However, the GPM satellite has performed better, because it has advanced technology when compared with the TRMM (Liu, 2016; Prakash et al., 2018).

Fusions of the rainfall measurement method using rain gauges with the estimates provided by satellites enable the validation of estimated satellite data (GPM) and mitigate the consequences of environmental disasters. This study therefore sought to evaluate and validate rainfall estimates from the GPM satellite in the Southern Amazonas region, compared with the measured data collected at the ground stations.

\section{MATERIALS AND METHODS}

\subsection{Study area}

The municipalities of Humaitá (HT; $7.30^{\circ} \mathrm{S}, 63.01^{\circ} \mathrm{W}$ and $\left.58 \mathrm{~m}\right)$, Boca do Acre (BA; $8.45^{\circ} \mathrm{S}, 67.23^{\circ} \mathrm{W}$ and $116 \mathrm{~m}$ ), Manicoré (MN; $5.48^{\circ} \mathrm{S}, 61.18^{\circ} \mathrm{W}$, and $45 \mathrm{~m}$ ), Apuí (AP; $7.11^{\circ} \mathrm{S}, 59.53^{\circ} \mathrm{W}$ and $135 \mathrm{~m}$ ) and Lábrea (LB; $7.15^{\circ} \mathrm{S}, 64.47^{\circ} \mathrm{W}$ and $75 \mathrm{~m}$ ) are located in the Northern region of Brazil, in the South of the Amazonas State (Figure 1). This region covers an area of modifications between the ecosystems of dense forests and natural fields mainly composed of grasses and low mesophilic surrounding forests, high evergreen forests, palm trees, Brazilian nut trees and others (Pavão et al., 2016).

The climate in the study area, according to Köppen's classification, is rainy tropical, in other words, a short dry season (June through August) and a long rainy season (October through March) with no hydric deficit. The annual average rainfall is of $2500 \mathrm{~mm}$ and the average temperature is of $25^{\circ} \mathrm{C}$ (Vidotto et al., 2007).
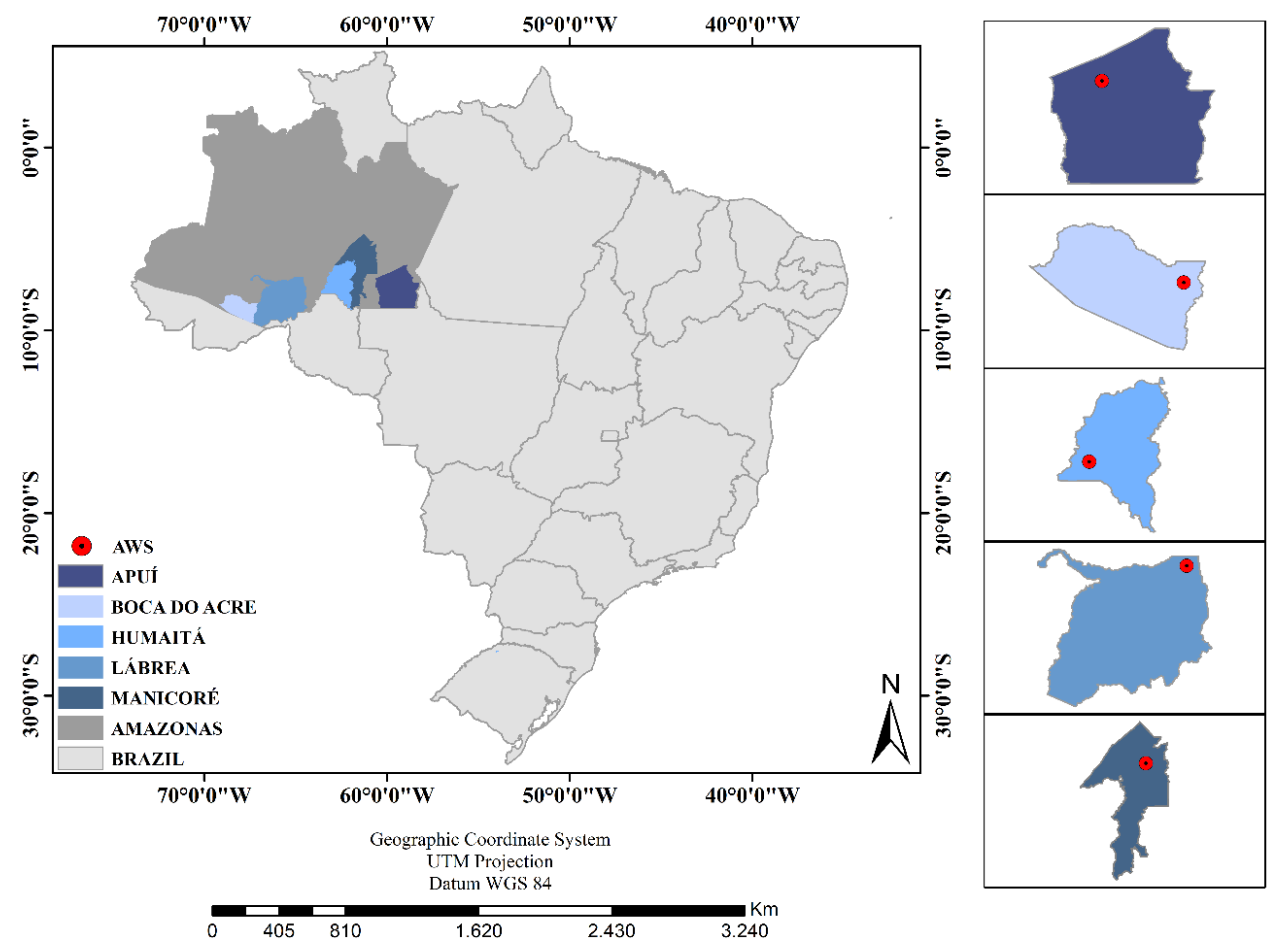

Figure 1. Location of the municipalities of Apuí (AP), Boca do Acre (BA), Humaitá (HT), Lábrea (LB), Manicoré (MN) and Automatic Weather Station (AWS), in Southern Amazonas State, Brazil. 


\subsection{Data}

In this study, we have used data from the GPM_3IMERGM v04 final run. In this algorithm, the IMERG shows data latency of 2 months after the observation period, allowing correction and a better estimate process. Afterwards, the data collected and estimated by Global Precipitation Mission (GPM) are available in the National Aeronautics and Space Administration (NASA) website (https://giovanni.gsfc.nasa.gov/). We have used data for the period of 2015 and 2016 covering the Southern Amazonas region. At the surface, we have used the records from rainfall measurement stations of the Agência Nacional de Águas - ANA (National Water Agency) (http://hidroweb.ana.gov.br/default.asp) and the meteorological stations of the Instituto Nacional de Meteorologia - INMET (National Meteorology Institute) which are deployed in the study area.

The Ppt estimates were taken considering the same coordinates of each surface station as a GPM central point of grid, which covers an area of $10 \times 10 \mathrm{~km}$. We highlight that according to the World Meteorological Organization (WMO), report n. 544, the horizontal radius of a weather station would not exceed $250 \mathrm{~km}$, or $300 \mathrm{~km}$ in sparsely populated regions (WMO, 2003), fitting perfectly with the observed area of a GPM satellite.

\subsection{Statistical analysis}

The data were processed on the basis of yearly and monthly averages. The relation between the measured values and the estimated ones was made through the Pearson " $r$ " correlation index, the analysis of accuracy through Willmott " $d$ " index (Equation 1), which links the distance of the estimated values in comparison with the observed ones, and its values vary between 0, for no matching, and 1, for perfect matching (Machado et al., 2015). The Root Mean Square Error - RMSE (Equation 2) was also analyzed, indicating that the model presents failures in the comparison between the estimated and the measured values, and the Mean Absolute Error - MAE (Equation 3), which indicates the absolute mean distance (deviation) between the estimated and measured values. In both errors, the values must be close to zero (Machado et al., 2015).

$$
\begin{aligned}
& d=1-\left[\frac{\sum\left(P_{i}-O_{i}\right)^{2}}{\sum\left(\left|P_{i}-O\right|+\left|O_{i}-O\right|\right)^{2}}\right] \\
& R M S E=\sqrt{\frac{\sum\left(P_{i}-O_{i}\right)^{2}}{n}} \\
& M A E=\sum \frac{\left|P_{i}-O_{i}\right|}{n}
\end{aligned}
$$

Where $P_{1}$ are estimated values, $O_{i}$ are observed values, $O$ the average of the observed values, and $n$ indicates the total number of samples.

\section{RESULTS AND DISCUSSION}

The municipalities of HT and AP had the lowest errors and the highest "r" values, respectively (Table 1). A Ppt underestimation by the GPM was observed. However, in general, the GPM adequately estimated the monthly and yearly rainfall values with correlations above $73 \%$. The municipality of Lábrea presented a higher $M A E$ and a lower correlation. BA had the highest RMSE and MN had a good correlation.

The " $r$ " coefficient correlation varied between 0.74 and 0.95 , and the Willmott index of concordance was between 0.83 and 0.97 among the analyzed municipalities. It was observed that the existing differences between the derivative data from GPM satellite and those from the 
meteorological stations can be considered as a result of the distinction of scale among them. The pluviometer presents a specific estimate, whereas the satellite represents a mean estimate in the analyzed pixel, which, together with the characteristics of each region, may cause different correlations in distinct areas (Almeida et al., 2015), once IMERG can present systematic differences due to surface type and precipitation rates (Liu, 2016). Another explanation is the fact that there is no predisposition from these estimative models to systematically over - or underestimate the rainfall measurements (Collischonn, 2006). A study comparing the monthly integration of multisatellite retrievals for the GPM has also observed positive and negatives differences over land regions (Liu, 2016). The author also has noticed that difference is more significant in regions near the ITCZ.

GPM errors, whether too high or too low, are related to the nature of the analyzed event. The estimative correlation therefore can be strongly affected by examined areas which are close to the measuring stations where no Ppt was recorded. On the other hand, in the observed cells that are distant from the rainfall measuring stations, the events of higher intensity are minimized due to the smooth essence of the data interpolation by the inverse of the distance towards the square. Therefore, the Ppt series approximates the most consistent average measured values (Almeida et al., 2015; Collischonn, 2006). Similar results have been found in a study carried out in India, where monthly variations of mean rainy days and heavy rain events showed good agreement to based-gauge observations (Prakash et al., 2018).

Table 1. Statistical indicators of the relation between the mean rainfall and the estimated for the municipalities of Apuí (AP), Boca do Acre (BA), Humaitá (HT), Lábrea (LB) and Manicoré (MN) in Southern Amazonas State, Brazil. MAE: Mean Absolute Error. RMSE: Root Mean Square Error. "r": Pearson correlation index. "d": Willmott index. *, p < 0.05; **, p < 0.01; ***, p < 0.001 .

\begin{tabular}{ccccc}
\hline City & MAE & RMSE & “d” & "r" \\
\hline AP & 36.50 & 13.81 & 0.97 & $0.95^{* * *}$ \\
BA & 56.92 & 71.76 & 0.91 & $0.85^{* * *}$ \\
HT & 49.34 & 19.73 & 0.91 & $0.86^{* * *}$ \\
LB & 72.49 & 23.42 & 0.84 & $0.74 * *$ \\
MN & 41.47 & 17.44 & 0.83 & $0.86^{* * *}$ \\
\hline
\end{tabular}

The GPM, in general, underestimated the rainfall records (Table 2). The highest underestimation was observed in the municipality of HT (16\%) and the lowest in MN (2\%). In BA, an overestimation of $12 \%$ was observed. In the wet season, in HT, the highest difference $(15 \%)$ of underestimation was observed and the lowest value was observed in AP (3\%). In the dry season, the satellite also inclined to underestimate in the municipality of LB with a dissimilar difference (262\%). In the municipality of MN, there was an overestimation (41\%). A study conducted in India to detect heavy rainfall event frequency by using IMERG and compare it with gauge-based observations, showed great results (Prakash et al., 2016). This lowest underestimation can be explained by the high frequency of rain events during the wet season (Pedreira Junior et al., 2018), while the discrepancies during the dry season are consequences of convective and stratiform rain reduction, which are more evident in the rainy season.

In the dry season, the reduction of the processes of precipitation formation that are associated with factors such as climatic conditions and regional particularities may result an error reading by the satellite, overestimating or strongly underestimating rainfall measures (Anjos et al., 2016). Further, these errors may be tied to the low temporal resolution of the satellite images that may undermine the capture of the measurements and the cloud brightness temperature (Pscheidt et al., 2008). 
Table 2. Annual and season variability of the measured and estimated rainfall for the municipalities of Apuí (AP), Boca do Acre (BA), Humaitá (HT), Lábrea (LB) and Manicoré (MN), in the Southern Amazonas State, Brazil. WS: Wet Season; DS: Dry Season.

\begin{tabular}{ccccccccccc}
\hline \multirow{2}{*}{ Municipalities } & \multicolumn{3}{c}{ Measured $(\mathbf{m m})$} & \multicolumn{3}{c}{ Estimated $(\mathbf{m m})$} & \multicolumn{3}{c}{ Differences $(\mathbf{m m})$} \\
\cline { 2 - 10 } & Annual & WS & DS & Annual & WS & DS & Annual & WS & DS \\
\hline AP & 1936 & 1782 & 154 & 1822 & 1725 & 96 & -114 & -57 & -58 \\
BA & 1946 & 1820 & 126 & 2200 & 2112 & 88 & 254 & 293 & -38 \\
HT & 2105 & 2024 & 81 & 1822 & 1761 & 61 & -283 & -263 & -20 \\
LB & 2132 & 1896 & 237 & 2056 & 1991 & 66 & -76 & 95 & -171 \\
MN & 2417 & 2297 & 119 & 2358 & 2156 & 202 & -59 & -141 & 82 \\
\hline
\end{tabular}

In the period of 2015 and 2016, the satellite yearly average was $2052 \mathrm{~mm}_{\text {year }}{ }^{-1}$, while the surface average was $2109 \mathrm{~mm}^{\text {year }}{ }^{-1}$ (Figure 2). The best estimate results are the ones for the municipality of MN and the worst performance was observed in the municipality of HT. The yearly mean spatial variability of precipitation estimated by the GPM satellite in the years of 2015 and 2016 were concentrated in the Northern part of Southern Amazonas State (Figure 3). In 2015, a set with rainfall values varying between 98 and $250 \mathrm{~mm} \mathrm{month}^{-1}$ was observed in this region. In average terms, the estimated values correspond greatly to values measured by the gauge-based values, both in temporal and spatial distribution. In 2016, the spatial variability of rainfall had a more homogeneous character all over the region, with values from 115 to $250 \mathrm{~mm} \mathrm{month}^{-1}$.

These values are associated with the meteorological systems that operate in this region, such as the South Atlantic Convergence Zone (ZCAS), the South American Monsoonal System (SMAS), the Intertropical Convergence Zone (ZCIT), the Instability Lines (LI), the Bolivian High Pressures (AB) and front systems (cold fronts) (Rickenbach, 2004; Vera et al., 2006).

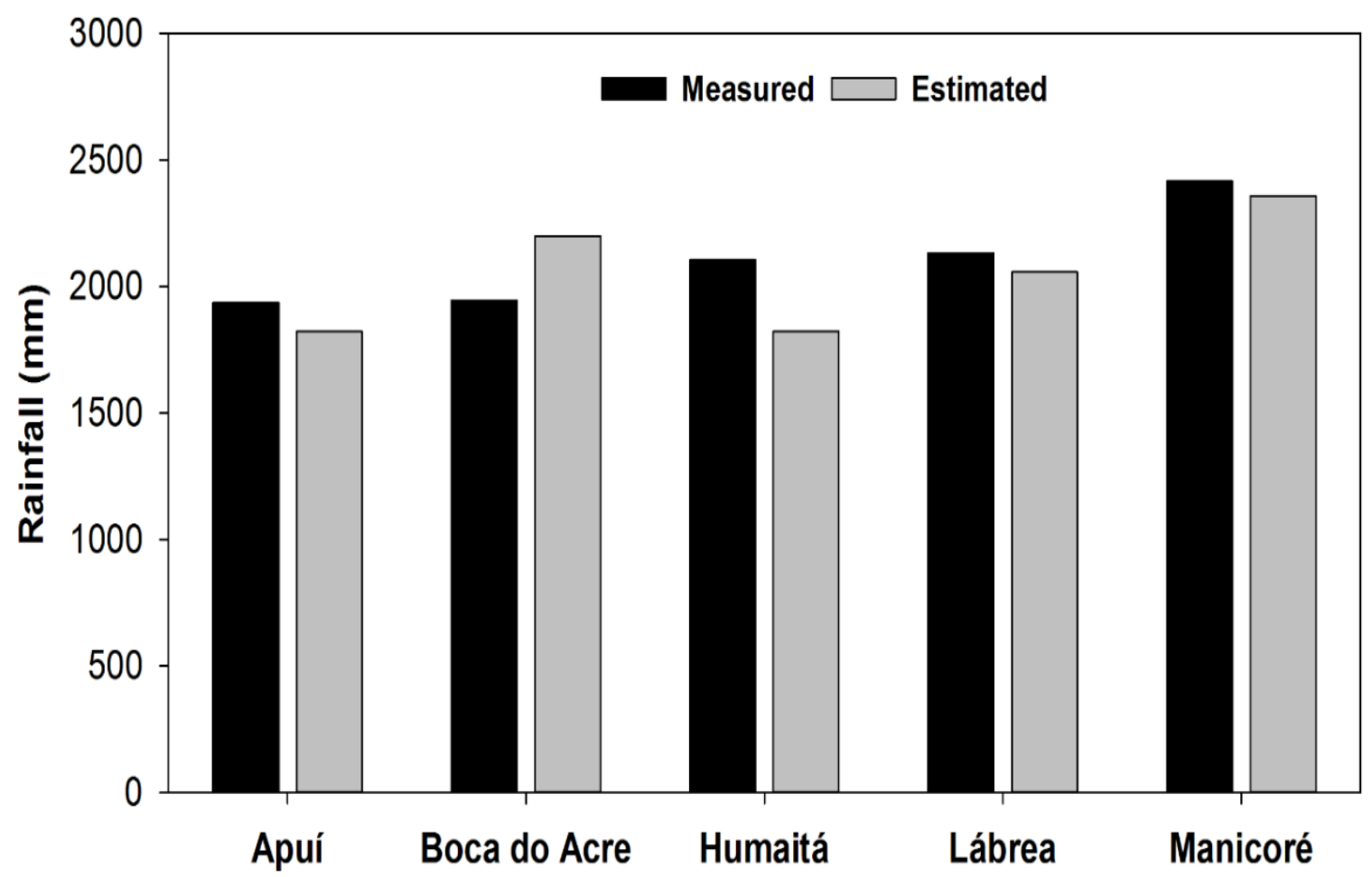

Figure 2. Yearly rainfall estimated by the GPM and measured by the based-gauge in the municipalities of the Southern Amazonas State (Brazil). 


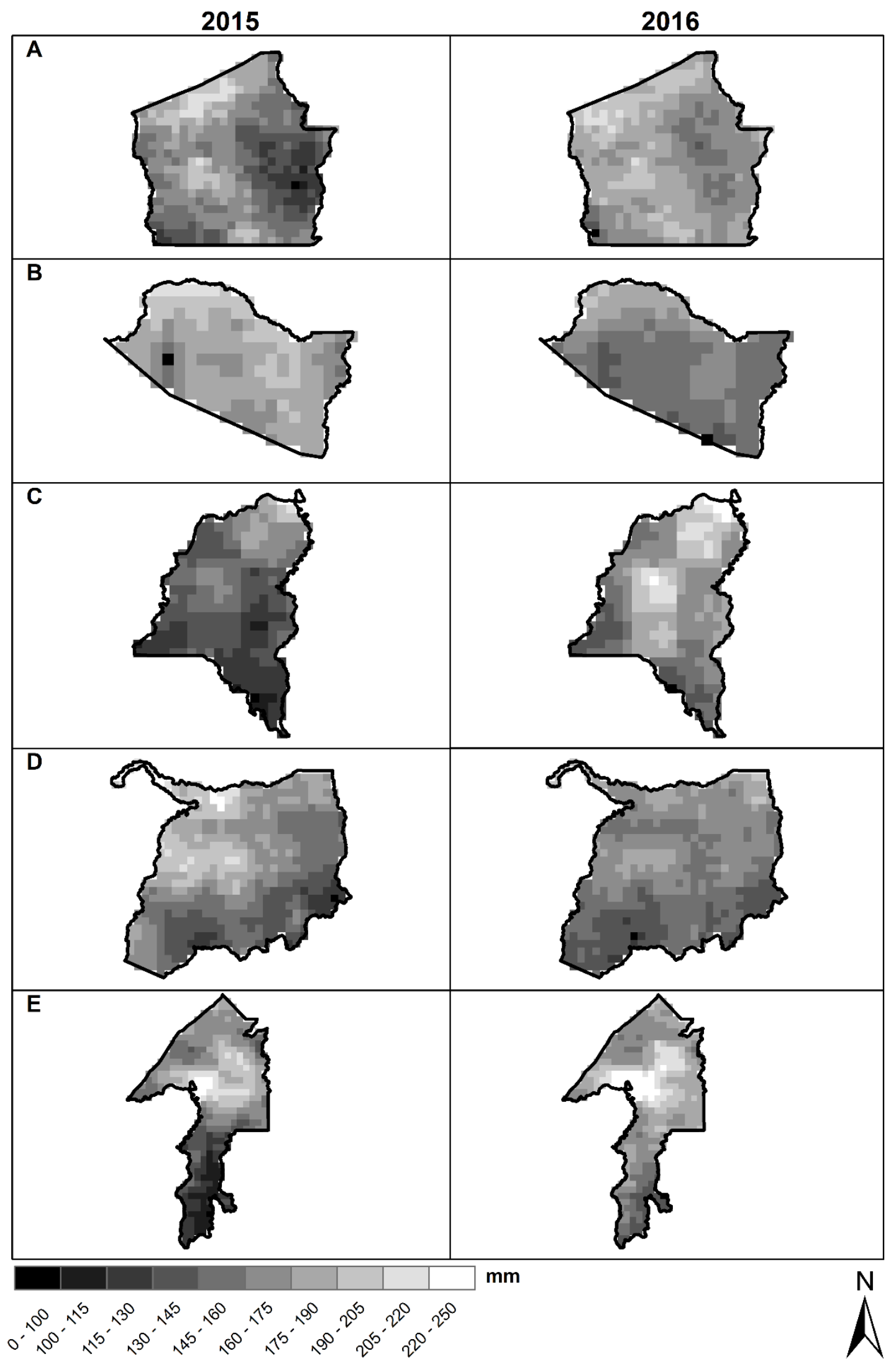

Figure 3. Yearly mean spatial variability of estimated rainfall by the GPM satellite in the Southern Amazonas State in 2015 and 2016. A: Apuí, B: Boca do Acre, C: Humaitá, D: Lábrea, E: Manicoré. 


\section{CONCLUSION}

The rainfall estimates provided by the GPM are consistent and can satisfactorily reflect precipitation occurrences in Southern Amazonas State (Brazil). The statistical indicators show that there is a rainfall correlation between these two methods with its multiple $r$ presenting a descriptive value in the quality of the obtained adjustment.

Seasonal variations of the rain are represented accordingly. In some cases, either an underestimation or an overestimation of the rain data was observed. In the yearly totals, a high rate of similarity between the estimated and measured values was observed.

Finally, this paper highlights that the GPM estimates can be used, even though they are not $100 \%$ reliable. Thus, studies that may generate adjustment equations for better estimates are expected in the future.

\section{ACKNOWLEDGEMENTS}

We appreciate the support given by the Programa Institucional de Bolsas de Iniciação Científica - IC (Institutional Program of Scientific Initiation Scholarship) induced demand PIBMULT - multidisciplinary - UFAM, Project Number PIB-E / 0437/2017 for the concession of PIBIC Scientific Initiation for the first author. This study's authors are also thankful to the Instituto Nacional de Meteorologia - INMET, the Agencia Nacional de Aguas - ANA and the National Aeronautics and Space Administration - NASA for its data availability.

\section{REFERENCES}

ALMEIDA, C. T. C.; OLIVEIRA JUNIOR, J. F.; GOIS, G.; CAVALCANTI, A. S. Avaliação das Estimativas de Precipitação do Produto 3B43-TRMM do Estado do Amazonas. Revista Floresta e Ambiente, v. 22, p. 279-286, 2015. https://doi.org/10.1590/21798087.112114

ANJOS, R. S.; NÓBREGA, R. S.; ARAÚJO, F. E.; ROCHA FILHO, G. B. R. Spatial distribution of rain types in Pernambuco with the usage of Remote Sensing. Journal of Hyperspectral Remote Sensing, v. 6, n. 3, p. 154-163, 2016. http://dx.doi.org/10.5935/2237-2202.20160016

COLLISCHONN, B. Uso de precipitação estimada pelo satélite TRMM em modelo hidrológico distribuído. 2006. Dissertação (Mestrado em recursos hídricos e saneamento ambiental) - Universidade Federal do Rio Grande do Sul, Porto Alegre, 2006.

GIRÃO, O.; CORRÊA, A. C. B. A contribuição da geomorfologia para o planejamento da ocupação de novas áreas. Revista de Geografia, v. 21, n. 2, 2004.

HOU, Y. A.; KAKAR, R. K.; NEECK, S.; AZARBARZIN, A. A.; KUMMEROW, C. D.; KOJIMA, M. et al. The Global Precipitation Measurement Mission. American Meteorological Society, 95, p. 701- 722, 2014. https://doi.org/10.1175/BAMS-D-1300164.1

LIU, Z. Comparison of Integrated Multisatellite Retrievals for GPM (IMERG) and TRMM Multisatellite Precipitation Analysis (TMPA) Monthly Precipitation Products: Initial Results. American Meteorological Society, v. 17, p. 777-790, 2016. https://doi.org/10.1175/JHM-D-15-0068.1 
MACEDO, A. M.; TEIXEIRA, W. Sul do Amazonas, nova fronteira agropecuária? O caso do município de Humaitá. In: SIMPÓSIO BRASILEIRO DE SENSORIAMENTO REMOTO, 14., 2009. Anais... São José dos Campos, 2009.

MACHADO, N. G.; MEIRELLES, T.; DANELICHEN, V. H. M.; QUERINO, C. A. S.; BIUDES, M. S. Estimation of Rainfall by Neural Network Over a Neotropical Region. Revista Brasileira de Climatologia, v. 17, p. $44 \quad$ - 54, 2015. http://dx.doi.org/10.5380/abclima.v17i0.40799

MARENGO, J. A.; BETTS, R. Riscos das mudanças climáticas no Brasil. Análise conjunta Brasil-Reino Unido sobre os impactos das mudanças climáticas e do desmatamento na Amazônia. São Paulo: CCST-INPE; 2011.

PAVÃO, V. M.; QUERINO, C. A. S.; BENEDITTI, C. A.; PAVÃO, L. L.; QUERINO, J. K. A. S.; MACHADO, N. G. et al. Variação espacial e temporal do saldo de radiação superficial em uma área do sul do Amazonas, Brasil. RA'E GA - O Espaco Geografico em Analise, v. 37, p. 333-352, 2016. http://dx.doi.org/10.5380/raega.v37i0.42469

PEDREIRA JUNIOR, A. L.; QUERINO, C. A. S.; QUERINO, J. K. A. S.; SANTOS, L. O. F.; MOURA, A. R. M.; MACHADO, N. G. et al. Variabilidade horária e intensidade sazonal da precipitação no município de Humaitá - AM. Revista Brasileira de Climatologia, v. 22, p. 463-475, 2018. http://dx.doi.org/10.5380/abclima.v22i0.58089

PRAKASH, S.; MITRA, A. K.; AGHAKOUCHAK, A.; LIU, Z.; NOROUZI, H.; PAI, D. S. A preliminary assessment of GPM-based multi-satellite precipitation estimates over a monsoon dominated region. Journal of Hydrology. v. 556, p. 865-876, 2018. https://doi.org/10.1016/j.jhydrol.2016.01.029

PRAKASH, S.; MITRA, A. K.; PAI, D. S; AGHAKOUCHAK, A. From TRMM to GPM: How well can heavy rainfall be detected from space. Advances in Water Resources. v. 88, p. $1-7,2016$.

PSCHEIDT, I. BENETI, C.; CALVETTI, L. Validação das estimativas de chuva por satélite para o estado do Paraná. In: CONGRESSO BRASILEIRO DE METEOROLOGIA, 15. São Paulo, 2008. Anais... Rio de Janeiro: SBMET, 2008.

REIS, J. B. C. Monitoramento e alerta de inundação no município de itajubá (MG) através de modelos matemáticos. 2014, Dissertação (Mestrado em Meio Ambiente e Recursos Hídricos) - Universidade Federal de Itajubá, Itajubá, 2014.

RICKENBACH, T. M. Nocturnal cloud systems and the diurnal variation of clouds and rainfall in Southwestern Amazonia. Monthly Weather Review, v. 132, p. 1201-1219, 2004. https://doi.org/10.1175/1520-0493(2004)132\%3C1201:NCSATD\%3E2.0.CO;2

VERA, C.; HIGGINS, W.; AMADOR, J.; AMBRIZZI, T.; GARREAUD, R.; GOCHIS, D. et al. Towards a unified view of the American Monsoon System. Journal Climate 19, 4977500, 2006. https://doi.org/10.1175/JCLI3896.1

VIDOTTO, E.; PESSENDA, L.C. R.; RIBEIRO, A. S.; FREITAS, H. A.; BENDASSOLLI, J. A. Dinâmica do ecótono floresta-campo no sul do estado do Amazonas no Holoceno, através de estudos isotópicos e fitossociológicos. Acta Amazônica, v. 37, n. 3, p. 385400, 2007.

WORLD METEOROLOGICAL ORGANIZATION - WMO. Manual on the Global Observing System. Geneva, 2003. 50 p. 


\begin{tabular}{|c} 
Ambiente \& Água - An Interdisciplinary Journal of Applied Science \\
ISSN 1980-993X - doi:10.4136/1980-993X \\
www.ambi-agua.net \\
E-mail: ambi.agua@gmail.com
\end{tabular}

\title{
Histopathological and hematological biomarkers in tambaqui Colossoma macropomum (Cuvier, 1816) from an environmental protection area of Maranhão, Brazil
}

\author{
ARTICLES doi:10.4136/ambi-agua.2266
}

Received: 04 Apr. 2018; Accepted: 23 Oct. 2018

\author{
Jonatas da Silva Castro ${ }^{1 *(D)}$; Camilla Fernanda Lima Sodré ${ }^{(D)}$; \\ Caroline Bogéa Souza ${ }^{2}$; ; Débora Batista Pinheiro Sousa ${ }^{3}$; \\ Raimunda Nonata Fortes Carvalho Neta ${ }^{2}$ iD

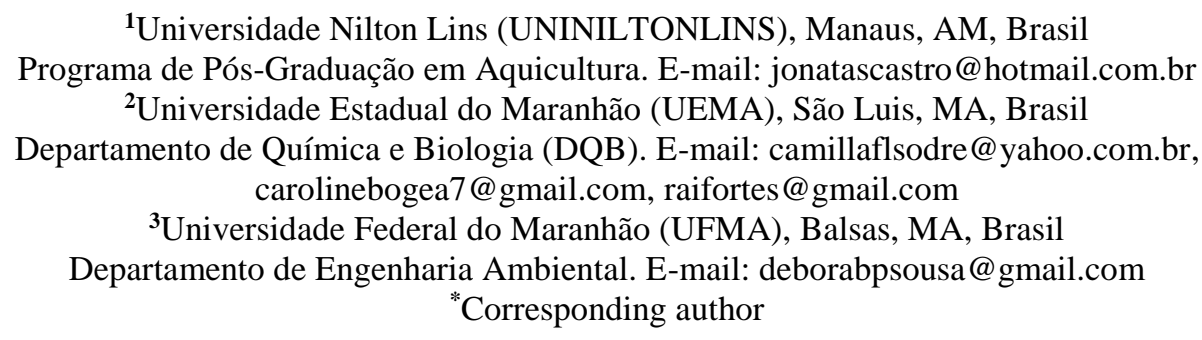

\section{ABSTRACT}

This study analyzed histopathological (gill lesions) and hematological (erythrocyte abnormalities) changes in tambaqui (Colossoma macropomum) in order to evaluate the water quality of fish farms in the Environmental Protection Area (EPA) of Maracanã, Maranhão, Brazil. Specimens of tambaqui were captured in two areas of EPA: A1) Serena Lagoon, and A2) River Ambude, in two seasonal periods, rainy and dry. For the hematological analyses, slides were made from the blood smear collected from the branchial arch of the fish. In the laboratory, the gills of each specimen were fixed in 10\% formalin and maintained in $70 \%$ alcohol until the usual histological technique. The branchial changes were more frequent during the dry season in both areas. In the fish collection in A2, the following changes were noted: mucosal cells $(78 \%)$, lamellar fusion $(90 \%)$, lamellar disorganization (100\%), lamellar narrowing (100\%), and epithelial displacement (96\%). In the fish collection in A1, the main lesions were: aneurysm (88\%), dilation of the capillaries (82\%), rupture of the capillaries (60\%). In addition, nuclear alterations, such as binucleate cells (BC), cells with an evaginated nucleus (CEN) and cells with a lobulated carved nucleus (CLCN), were observed in the fish from both areas. The frequency of abnormalities was higher in the fish from A2 (74\%) when compared to the fish from A1 (26\%). In conclusion, we found that these alterations proved to be sensitive biomarkers capable of differentiating water quality and fish health status in the two systems in the Maracanã EPA.

Keywords: aquatic monitoring, gill lesions, water quality. 


\section{Biomarcadores histopatológicos e hematológicos em tambaqui Colossoma macropomum (Cuvier, 1816) de uma área de proteção ambiental do Maranhão, Brasil}

\section{RESUMO}

Objetivou-se neste estudo analisar as alterações histopatológicas (lesões branquiais) e hematológicas (anormalidades eritrocíticas) em tambaqui (Colossoma macropomum), para avaliação da qualidade de água de pisciculturas da Área de Proteção Ambiental (APA) do Maracanã, Maranhão, Brasil. Exemplares de tambaqui foram capturados em duas áreas da APA: A1) Lagoa Serena; A2) Rio Ambude, em dois períodos sazonais (chuvoso e seco). Para as análises hematológicas foram confeccionadas lâminas a partir do esfregaço de sangue coletado no arco branquial dos peixes. No laboratório as brânquias de cada espécime foram fixadas em formol a $10 \%$ e mantido em álcool a $70 \%$ até a execução da técnica histológica usual. As alterações braquiais foram mais frequentes no período de estiagem nas duas áreas analisadas. Em peixes coletados em A2, as seguintes alterações foram observadas: células mucosas (78\%), fusão lamelar (90\%), desorganização lamelar (100\%), estreitamento lamelar (100\%), deslocamento do epitélio (96\%). Em peixes coletados em A1, as principais lesões foram: aneurisma (88\%), dilatação dos capilares (82\%), rompimento dos capilares (60\%). Além disso, nos peixes de ambas as áreas foram observadas alterações nucleares, como células binucleadas (BC), células com núcleo evaginado (CEN) e células com núcleo entalhado lobulado (CLCN). A frequência de anormalidades foi maior nos peixes de A2 (74\%) quando comparada com os exemplares de A1 (26\%). Em conclusão, consideramos que essas alterações se mostraram biomarcadores sensíveis capazes de diferenciar a qualidade de água e o estado de sanidade dos peixes em dois sistemas aquáticos na APA do Maracanã.

Palavras-chave: lesões branquiais, monitoramento aquático, qualidade de água.

\section{INTRODUCTION}

The monitoring aquatic environments is an important and necessary process in the management of natural resources, since it offers the opportunity to diagnose the possible impacts caused by anthropic action. This process contributes with basic information to evaluate the presence of chemical contaminants and thus better comprehend their performance in the physiology of aquatic organisms. This knowledge is fundamental in order to generate policies relating to the management of aquatic systems (Brito et al., 2012).

Fish are used in aquaculture as a food source; however, because of their potential to accumulate pollutants present in the water column, and because of biomagnification by the trophic chain, they represent an important route of contamination for human populations (Oliveira Ribeiro et al., 2006). The different kinds of pollutants present in water and sediments can cause diverse modifications in different biological levels (cellular, tissue and systemic). Thus, these changes are considered as good indicators of the damage that both, organic and inorganic contaminants can cause in fish (Sousa et al., 2013).

Several methodologies have been applied in the assessment of the conditions of aquatic environments, such as biomarkers in fish. These analyses allow the identification of initial biological changes caused by the organisms' exposure to contaminants and may be useful to support monitoring and environmental management actions (Amaral et al., 2006). Among the advantages of applying this methodology, Sousa et al. (2013) highlight the speed, the low cost and the easy interpretation of results.

Tambaqui (Colossoma macropomum) is one of the species grown in Maracanã the EPA, 
standing out for its high economic and ecological value, because the species is cultivated in tanks and captured frequently in the rivers of the region. In addition, this species is considered a bioindicator due to the ease of handling and maintenance in the laboratory and has been used to evaluate the quality of aquatic environments (Fortes Carvalho Neta et al., 2015). A study carried out by Castro et al. (2014) revealed that the use of biomarkers in fish is efficient in support of public bodies' decisions, in order to carry out monitoring actions in these environments.

The EPA of Maracanã is located near the industrial district of a large city, São LuísMaranhão/Brazil, and suffers from pollution from the nearby industrial facilities. In addition, despite the requirement of the law that created the protected area, there is still no environmental management plan. In this sense, studies using biomarkers in fish from different aquatic environments, especially with rivers and with cultivation systems practiced in the region, can provide subsidies for biomonitoring that must be performed and can integrate the environmental management plan.

The objective of this study was to analyze the morphological (gill lesion) and hematological (erythrocyte abnormalities) biomarkers to evaluate the water quality of fish farms and the health condition of tambaqui of the Environmental Protection Area of Maracanã, São Luís, MA, Brazil.

\section{MATERIAL AND METHODS}

\subsection{Sample collection}

The capture of tambaqui was approved by the Ethics Committee of the State University of Maranhão (protocol number 21/2013) and complied with the guidelines of the Brazilian College of Animal Experimentation (COBEA; http://www.cobea.org.br). Forty specimens were collected at two collection points with gill nets: A1 = Serena Lagoon $(n=20)$; $A 2=$ Ambude River ( $n=20$ ), during the dry season of 2012 (October/November) and rainy season (April/May) of 2013.The first capture point is characterized as a semi-intensive fish farming system, presenting poor management of the animals, geographical coordinates $2^{\circ} 38^{\prime} 2.99^{\prime \prime} \mathrm{S} \mathrm{/}$ $44^{\circ} 17^{\prime} 55.58^{\prime \prime} \mathrm{W}$. The second capture site is characterized as being the source of the Ambude River, highly impacted by anthropic action, geographic coordinates $2^{\circ} 37^{\prime} 45.01^{\prime \prime} \mathrm{S} /$ $44^{\circ} 17^{\prime} 44.87^{\prime \prime} \mathrm{W}$ from the EPA of Maracanã (Figure 1). The animals were placed into plastic bags and kept in iceboxes to be transported to the Laboratory of Biomarkers in Aquatic Organisms (LabBOAq) of the State University of Maranhão, where biometric data regarding Total Length (TL), Standard Length (SL) in $\mathrm{cm}$ and Total Weight (WT) in g was determined. The sexual determination of the fish was according to the macroscopic evaluation of the gonads (Vazzoler, 1981).

\subsection{Physico-chemical parameters and water analyses}

Simultaneously to the fish catch, the physico-chemical parameters of the water such aspH, temperature, dissolved oxygen, turbidity and levels of ammonia, and nitrites were measured using a multiparameter probe (SX751 - SANXIN). Water samples were collected in triplicate from the Serena Lagoon (A1) and the Ambude River (A2) in order to determine the contaminant levels. The samples were analyzed for metals such as copper $(\mathrm{Cu})$, iron $(\mathrm{Fe})$, lead $(\mathrm{Pb})$, manganese $(\mathrm{Mn})$ and zinc $(\mathrm{Zn})$. The concentrations of metals in the water were determined in the Soil Laboratory of the UEMA, using Inductively Coupled Plasma Emission Spectrometry (ICP-Varian 720-ES). For the validation of the employed method, Standard Reference Material, 1640 Trace Elements in Water, U.S Department of Commerce, National Institute of Standards and Technology, Gaithersburg MD 20899 was used.The results were reported in milligrams 
$(\mathrm{mg} / \mathrm{L})$. Blanks and certified reference materials were used to ensure the quality of analyses. The measurements were performed in triplicate.

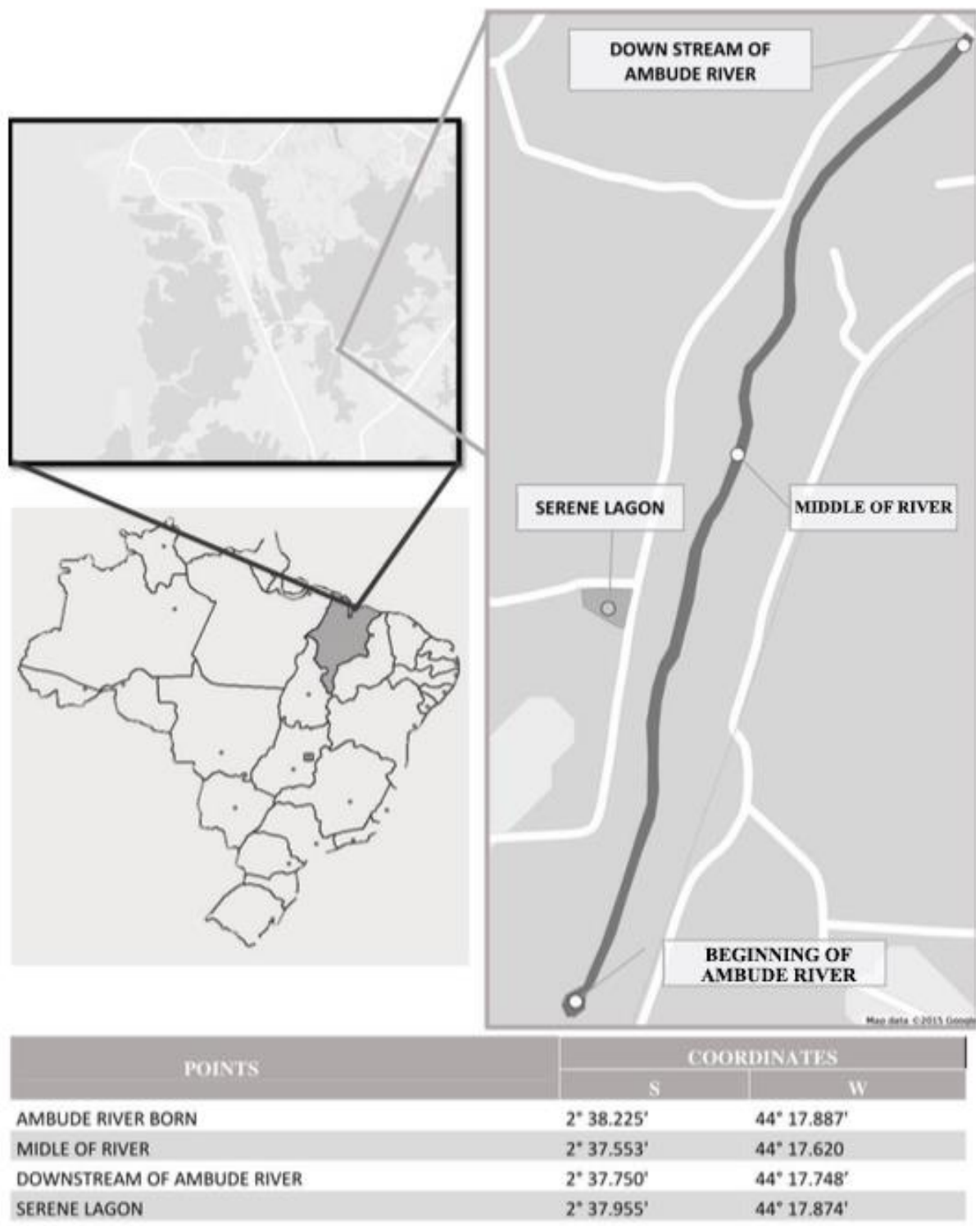

Figure 1. Capture region of specimens C. macropomum at EPA of Maracanã. Sites: Ambude River and Serena Lagoon.

\subsection{Hematological analyses}

Blood collection via the gill area was performed in the field. The fish were put in a vat of water and anesthetized with eugenol $(10 \mathrm{mg} / \mathrm{L})$, followed by blood collection using a heparinized syringe. The fish were then placed in plastic bags, put in boxes with ice and transported to the Laboratory of Biomarkers in Aquatic Organisms of the State University of Maranhão.

Genotoxic analyses were carried out from a blood smear obtained from a part of the blood of the branchial vessels. One drop of blood from each fish was dripped onto a microscopic slide in order to perform the smear. Subsequently, the slides were fixed in absolute ethanol during 30 minutes. After drying, the slides were stained in $10 \%$ Giemsa diluted in phosphate buffer, pH 6.8. Twenty slides were prepared from each fish and 2000 cells were analyzed for each slide, respectively. 


\subsection{Histopathological analyses}

The first branchial arch of each fish was removed and fixed in $10 \%$ formaldehyde. The gill samples were then dehydrated in increasing series of alcohol, deparaffinized in xylene, and included in paraffin. Cross sections of approximately $5 \mu \mathrm{m}$ thick were cut using a microtome (Leica RM2265). All observations of branchial lesions were made with a Zeiss light microscope (Carl Zeiss AG, Germany), equipped for the acquisition of images taken with the AxioCam camera (Zeiss, Jena, Germany). The histopathological changes were observed and photomicrographed. They were ordered according to the severity degree of the lesions, according to the scale - I (small injury), II (moderate injury), and III (severe injury), as suggested by Bernet et al. (1999).

\subsection{Data analyses}

The data were expressed by mean and standard deviation from the mean. The data were tested for their normality using the Shapiro-Wilk test. Subsequently, the number of gill and cell changes with micronucleus and morphological abnormalities between the areas were compared using the Student's t-test $(\mathrm{p}<0.05)$. The statistical analyses described were performed using the R Software (R Development Core Team 2016).

\section{RESULTS AND DISCUSSION}

The results of the physicochemical analyses of water are listed in Table 1 . The results of ammonia, temperature, $\mathrm{pH}$, dissolved oxygen, turbidity, and nitrite in each capture area are in accordance with the values recommended by CONAMA - Resolution $N^{\circ} 430 / 2011$. The metal concentrations $(\mathrm{Cu}, \mathrm{Fe}, \mathrm{Pb}, \mathrm{Mg}$ ) (Table 1) showed values higher than the acceptable limits (Class 2 waters - which can be used for aquaculture and fishing) defined by the Brazilian standard for some metals (CONAMA 357/2005 and 430/2011) in the A2 site.

Table 1. Abiotic data and transition metals values collected at the two capture sites of tambaqui at EPA of Maracanã, São Luís-MA.

\begin{tabular}{lccccc}
\hline Parameters & \multicolumn{3}{c}{ Dry season } & \multicolumn{3}{c}{ Rainy season } \\
\hline & A1 & A2 & A1 & A2 & ${ }^{a}$ Recommended values \\
\hline Ammonia $(m g ~ L)$ & 0.5 & 0.25 & 0.4 & 0.21 & $\leq 3.7 \mathrm{mg} / \mathrm{L}^{\mathrm{b}}$ \\
Turbidity $(\mathrm{mg} \mathrm{L})$ & 23.5 & 17 & 22 & 18 & $<100 \mathrm{UNT}$ \\
Dissolved $\mathrm{O}_{2}\left(\mathrm{mg} \mathrm{L}^{-1}\right)$ & 11 & 9 & 11.4 & 8.8 & $>5 \mathrm{mg} / \mathrm{L}^{\mathrm{b}}$ \\
$\mathrm{pH}$ & 7.5 & 7,3 & 7.3 & 7 & $6.5-8.0^{\mathrm{b}}$ \\
Temperature $\left({ }^{\circ} \mathrm{C}\right)$ & 30 & 29.8 & 29.6 & 29.2 & $28-32^{\circ} \mathrm{C}^{\mathrm{b}}$ \\
Copper $\left(\mathrm{mg} \mathrm{L}^{-1}\right)$ & $\mathrm{ND}$ & 0.0160 & $\mathrm{ND}$ & 0.0159 & $\leq 0.009^{\mathrm{b}}$ \\
Iron $\left(\mathrm{mg} \mathrm{L}^{-1}\right)$ & $\mathrm{ND}$ & 2.59 & $\mathrm{ND}$ & 2.55 & $\leq 0.3^{\mathrm{b}}$ \\
Lead $\left(\mathrm{mg} \mathrm{L}^{-1}\right)$ & $\mathrm{ND}$ & 0.0317 & $\mathrm{ND}$ & 0.0314 & $\leq 0.01^{\mathrm{b}}$ \\
Manganese $\left(\mathrm{mg} \mathrm{L}^{-1}\right)$ & $\mathrm{ND}$ & 0.210 & $\mathrm{ND}$ & 0.320 & $\leq 0.1^{\mathrm{b}}$ \\
Zinc $\left(\mathrm{mg} \mathrm{L}^{-1}\right)$ & $\mathrm{ND}$ & 0.195 & $\mathrm{ND}$ & 0.210 & $\leq 0.18^{\mathrm{b}}$ \\
\hline
\end{tabular}

$\mathrm{mg}=$ milligrams; $\mathrm{L}=$ liters; ${ }^{\mathrm{b}}$ Recommended values are based on Resolution Number 357 of the Brazilian National Environmental Council (CONAMA, 2005; 2011); $\mathrm{ND}=$ not detected.

In the present study, higher values of ammonia, $\mathrm{pH}$, and turbidity were observed in the Serena Lagoon, probably due to the lack of water circulation and the excessive use of animal food in the environment, since this is a fish pond. According to Mercante et al. (2008), the increase in $\mathrm{pH}$ in the environment is associated with the increase of ammonia. In cultivation ponds, the main sources of incorporated nitrogen compounds occur through feed, animal food, 
and fertilizers used in the nurseries which contain nitrogen, mainly in the form of ammonia and nitrate. The excess of these elements in the cultivation environment can delay the fish growth, besides being nutrients consumed by phytoplankton, causing the excessive growth of these algae, leading to eutrophication of the environment, hindering the penetration of light (Mercante et al., 2008).

The Ambude River showed the presence of all measured metals, with high values of $\mathrm{Cu}$, $\mathrm{Pb}$, and $\mathrm{Fe}$. These findings can be related to the anthropic activities carried out at this site caused by liquid residues and pollution originated from the absence of basic sanitation. The presence of housing and communities along the aquatic bodies, as well as the use of pesticide chemicals from agriculture, domestic and industrial effluents that are considered to be major sources of metals for aquatic environments (Moiseenko and Kudryavtseva, 2001).

The statistical analyses of the results of the biometric data for male and female tambaqui from the two sites of EPA of Maracanã are expressed in Table 2. The fish collected in Serena Lagoon had higher values of total weight, total length and standard length in relation to the specimens collected in Ambude River.

Table 2. Biometric data of male and female fish collected at Serena Lagoon (A1) and Ambude River (A2), EPA of Maracanã, São Luís-MA.

\begin{tabular}{lcccc}
\hline \multicolumn{5}{c}{ Average \pm Standard deviation } \\
\hline Parameters & \multicolumn{2}{c}{ Serena Lagoon } & \multicolumn{2}{c}{ Ambude River } \\
\hline \multicolumn{4}{c}{ (Dry Season) } & \multicolumn{2}{c}{ (Rainy Season) } \\
\hline TL $(\mathrm{cm})$ & Females & Males & Females & Males \\
SL $(\mathrm{cm})$ & $27,5 \pm 2,36$ & $32,4 \pm 3,33$ & $23,4 \pm 4,8$ & $20,4 \pm 4,4$ \\
TW $(\mathrm{cm})$ & $646,5 \pm 112,33$ & $568,9 \pm 165,93$ & $330,4 \pm 51,40$ & $230,2 \pm 51,7$ \\
\hline
\end{tabular}

The biometric data of the analyzed specimens confirm that there is some alteration in the fish tanks and in the EPA of Maracanã's rivers. The data obtained for the fish in A2 presented lower values of total length (TL), standard length (SL) and total weight (TW) in relation to the specimens collected in the A1. These results entrench the influence of potentially contaminated environments on the zootechnical performance of these animals. The presence of transition metals such as iron, copper, zinc, and cobalt in aquatic environments are considered essential elements of biological processes; however, concentrations above the required level of these elements lead to organic dysfunctions including lack of appetite, reduced growth and stress (Gharedaashi et al., 2013).

Nuclear morphological changes (NC) and micronuclei were found in erythrocytes of $C$. macropomum at both sampling sites, but did not present seasonal differences between the areas $(\mathrm{p}>0,05)$. However, the highest values were found in the dry period. The main types of NC were: binucleate cell (BC), cell with an evaginated nucleus (CEN) and cell with a lobed grooved core (CLGC) (Figure 2). The abnormalities were more frequent in the Ambude River (74\%) than in the Serena Lagoon (26\%).

The hematological changes showed that fish from both areas suffer some kind of environmental impact related to substances probably derived from the leaching process of agrochemicals from the farming systems in the region or from industrial activities carried out in the vicinity of the EPA of Maracanã. According to Souza and Fontanelli (2006), the abnormalities found in fish erythrocytes may be related to cytotoxicity processes, influences on cell division and genotoxicity or mutagenicity. The morphological changes found in fish erythrocytes may appear as a consequence of the effect of chemical, toxic, genotoxic, mutagenic 
and carcinogenic contaminants to which fish are exposed in a contaminated environment (Palhares e Grisolia, 2002). According to Fenech (2000), these abnormalities are related to errors occurring during mitosis or meiosis, with cell death processes (necrosis and apoptosis), as well as genotoxicity and mutagenicity.

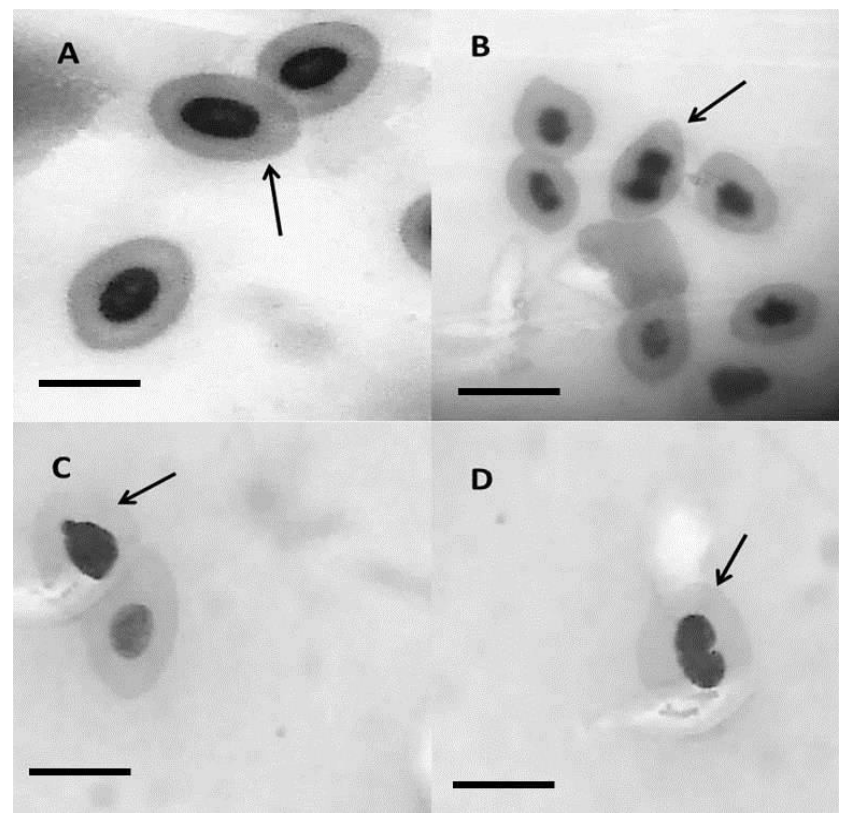

Figure 2. Photomicrography of C. macropomum erythrocytes collected at Serena Lagoon, APA of Maracanã. A) Erythrocytes showing normal cells (arrow); B) Erythrocytes showing a binucleated cell (arrow); C) Erythrocytes showing a cell with an evaginated nucleus (arrow); D) Erythrocytes showing a lobed grooved cell. Giemsa 100x.

The histopathological analyses performed on the fish gills collected from both regions of EPA of Maracanã showed the following morphological changes: mucosal cells, lamellar fusion, lamellar disorganization, lamellar narrowing, epithelial displacement, aneurysm, capillary dilatation and capillary rupture. The fish captured from the Ambude River had a higher percentage of branchial lesions in both seasons, rainy and dry (Figure 3).

In general, the analyses performed on the fish gills presented lesions of different severity levels (Bernet et al., 1999). The fish from the Ambude River presented the highest percentage of branchial alterations; this factor could be related to the leaching process of the pollutants, which are carried by the rain to the rivers. Castro et al. (2014) when analyzing the H. malabaricus species collected in the same region, identified lesions similar to those found in this study.The authors suggest the hypothesis that such lesions were caused by the release of rural and industrial effluents in the aquatic bodies of this region. Fortes Carvalho Neta et al. (2015) affirm that pollution in this region has intensified in recent years, both by the agropastoral systems and by the large industries installed around this Environmental Protection Area, causing serious problems in the aquatic environment, such as the decrease of dissolved oxygen, temperature oscillation, lack of nutrients and also the eutrophication of these environments. Our results are in agreement with the data found by Fortes Carvalho Neta et al. (2015) and Castro et al. (2014) and indicate that all these problems can cause stress to the fish and cause changes in their morphological structures, such as the severe branchial lesions found in the specimens analyzed in the Ambude River.

\section{IPABH}



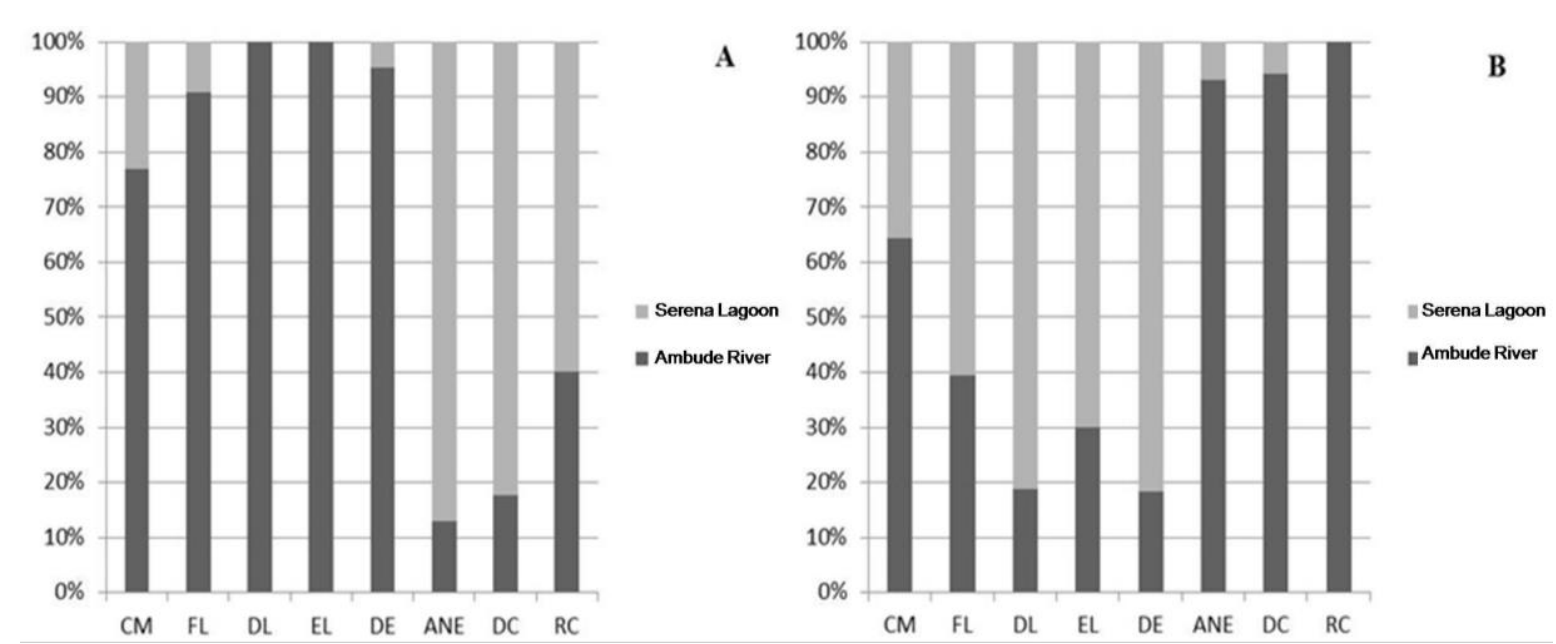

Figure 3. (A) Percentage of the branchial lesions found in the fish from the Ambude River and the Serena Lagoon in the dry season; (B) Percentage of the branchial lesions found in the fish from the Ambude River and the Serena Lagoon in the rainy season. CM (mucous cells); FL (lamellar melting); DL (lamellar clutter); EL (lamellar narrowing); DE (displacement of the epithelium); ANE (aneurysm); DC (dilation of capillaries); RC (capillary rupture).

Studies performed by Nogueira et al. (2008), using the species Pimelodus maculatus captured in the Furnas-MG reservoir (Brazil), identified the following lesions: aneurysm, cell proliferation in the secondary lamella and branchial filament, epithelial displacement in the branchial filament, hypertrophy, blood congestion in the marginal bloodstream and lamellar fusion; these injuries are related to the development of agricultural activities that are being carried out near the reservoir banks, contributing to an increase in the entrance of fertilizers and raw sewage in several areas. These data are similar to those obtained for the fish in the present study. Nevertheless, the biomarkers we used are effective in indicating the effect of pollutants, but they are not specific. This suggests that studies on other biomarkers and additional chemical analyzes on water and sediment should be undertaken in the region to support a biomonitoring program for the Environmental Protection Area.

\section{CONCLUSIONS}

The frequency of gill changes and nuclear alterations in tambaqui erythrocytes was higher in A2 than in A1, indicating that fish from the river are under more intense stress due to pollution from the industrial zone located near the EPA of Maracanã. However, the fish farming systems are also presenting responses that indicate stress, probably due to inappropriate management practices in the fish farms in the Environmental Protection Area. The biomarkers evaluated indicated that the health of fish from the EPA of Maracanã may be affected; in addition, the quality of the fish produced in the fish farming systems of the region needs to be monitored.

\section{ACKNOWLEDGEMENTS}

We would like to thank the Foundation for Scientific Research and Development of Maranhão (FAPEMA) for granting the scholarship to the first author, the Group of Research in Ecotoxicology and Monitoring of Aquatic Environments (GPEMAAq) of the State University of Maranhão, and the staff of the Laboratory of Biomarkers in Aquatic Organisms (LABOAq) for all the support. 


\section{REFERENCES}

AMARAL, A.; SOTO, M.; CUNHA, R.; MARIGÓMEZ, I. \& RODRIGUES, A. Bioavailability and cellular effects of metals on Lumbricus terrestris in habiting volcanic soils. Environmental Pollution, v. 142, p. 103-108, 2006. https://doi.org/10.1016/j.envpol.2005.09.011

BERNET, D.; SCHIMIDT, H.; MEIER, W.; BURKHRADT-HOLM, WHALI, T. Histopatology in fish: proposal for a protocol to assess aquatic pollution. Journal Fishery Diseases, n. 22, p. 25-34, 1999. https://doi.org/10.1046/j.1365-2761.1999.00134.x

BRITO, I. A.; FREIRE, C. A.; YAMAMOTO, F. Y.; ASSIS, H. C. S.; SOUZA-BASTOS, L. R.; CESTARI, M. M. et al. Monitoring water quality in reservoirs for human supply through multi-biomarker evaluation in tropical fish. Journal of Environmental Monitoring, v. 14, p. 615-625, 2012. http://dx.doi.org/10.1039/C2EM10461J

CASTRO, J. S.; SILVA, J. S.; FREITAS, L. C.; CARVALHO-NETA, R. N. F. Biomarcadores histopatológicos na espécie Hoplias malabaricus(Pisces, Osteichthyes, Erythrinidae) em uma Unidade de Conservação de São Luís (MA). Arquivo Brasileiro de Medicina Veterinária e Zootecnia, v. 66, n. 6, p. 1687-1694, 2014. https://doi.org/10.1590/16787414

CONSELHO NACIONAL DO MEIO AMBIENTE CONAMA. Resolução $n^{\circ} 357$. Diário Oficial [da] União: seção 1, Brasília, DF, p. 1-23, 17 mar. 2005.

CONSELHO NACIONAL DO MEIO AMBIENTE CONAMA. Resolução $n^{\circ}$ 430. Diário Oficial [da] União: seção 1, Brasília, DF, n. 92, p. 89, 16 maio 2011.FENECH, M. The in vitro micronucleus technique. Mutation Research, v. 455, p. 81- 95, 2000. https://doi.org/10.1016/S0027-5107(00)00065-8

FORTES CARVALHO-NETA, R. N.; PINHEIRO-SOUSA, D. B.; DE MACÊDO SOBRINHO, I. C.; HORTON, E. Y.; ALMEIDA, Z. S.; TCHAICKA, L. et al. Genotoxic and hematological parameters in Colossoma macropomum (Pisces, Serrasalmidae) as biomarkers for environmental impact assessment in a protected area in northeastern Brazil. Environmental Science Pollution Research, v. 22, n. 20, p. 15994-16003, 2015. https://doi.org/10.1007/s11356-015-4748-4

GHAREDAASHI, E.; NEKOUBIN, H.; IMANPOOR, M. R.; TAGHIZADEH, V. Effect of copper sulfate on the survival and growth performance of Caspian Sea kutum, Rutilus frisii kutum. SpringerPlus, v. 2, p. 1- 5, 2013. https://doi.org/10.1186/2193-1801-2-498

MERCANTE, C. T. J.; ESTEVES, K. E.; PEREIRA, J. S.; OSTI, J. S. Limnologia na aquicultura: estudo de caso em pesqueiros. São Paulo: Instituto de Pesca, 2008. 15 p.

MOISEENKO, T. I.; KUDRYAVTSEVA, L. P. Trace metal accumulation and fish pathologies in areas affected by mining and metallurgical enterprises in the Kola region, Russia. Environmental Pollution, v. 114, p. 285-297, 2001. https://doi.org/10.1016/S02697491(00)00197-4

NOGUEIRA, D. J.; CASTRO, S. C.; RIGOLIN-SÁ, O. Utilização das brânquias de Astyanax altiparanae (Garutti \& Britski, 2000) (Teleostei, Characidae) como biomarcador de poluição ambiental no reservatório UHE Furnas-MG. Revista Brasileira de Zoociências, v. 11, p. 227-232, 2008.

\section{IPABH}

Rev. Ambient. Água vol. 14 n. 1, e2266 - Taubaté 2019 
OLIVEIRA RIBEIRO, C. A.; FILIPAK NETO, F.; MELA, M.; SILVA, P. H.; RANDI, M. A. F.; RABITTO, I. S. et al. Hematological findings in neotropical sh Hoplias malabaricus exposed to subchronic and dietary doses of methylmercury, inorganic lead, and tributyltin chloride. Environmental Research, v. 101, n. 1, p. 74- 80, 2006. https://doi.org/10.1016/j.envres.2005.11.005

PALHARES, D.; GRISOLIA, C. K. Comparison between the micronucleus frequencies of Kidney and gill erythrocytes in tilapia fish, following mitomycin C treatment. Genetics and Molecular Biology, v. 25, n. 3, p. 281- 284, 2002. http://dx.doi.org/10.1590/S141547572002000300005

SOUZA, T. S.; FONTANELLI, C. S. Micronucleus test and observation of nuclear alterations in erythrocytes of Nile tilapia exposed to waters affected by refinery effluents. Mutation Research, v. 605, p. 87- 93, 2006. https://doi.org/10.1016/j.mrgentox.2006.02.010

SOUSA, D. B. P.; ALMEIDA, Z. S.; FORTES CARVALHO NETA, R. N. Biomarcadores histológicos em duas espécies de bagres estuarinos da Costa Maranhense, Brasil. Arquivo Brasileiro de Medicina Veterinária e Zootecnia, v. 65, p. 369-376, 2013

VAZZOLER, A. E. A. de M. Manual de métodos para estudos biológicos de populações de peixes: reprodução e crescimento. Brasília: CNPq-Programa Nacional de Zoologia, 1981. $108 \mathrm{p}$. 


\begin{tabular}{|} 
Ambiente \& Água - An Interdisciplinary Journal of Applied Science \\
ISSN 1980-993X - doi:10.4136/1980-993X \\
www.ambi-agua.net \\
E-mail: ambi.agua@gmail.com
\end{tabular}

\title{
Defining environmental conservation levels considering anthropic activity in the Uberaba River Basin protected area
}

\author{
ARTICLES doi:10.4136/ambi-agua.2279
}

Received: 15 May 2018; Accepted: 01 Nov. 2018

\author{
Allita Rezende dos Santos ${ }^{1 *}$; Renato Carneiro Fernandes da Silva ${ }^{2}$; \\ Leonardo Campos de Assis ${ }^{2}$; Frederico Fábio Mauad ${ }^{1}$ (D) \\ ${ }^{1}$ Escola de Engenharia de São Carlos da Universidade de São Paulo (EESC-USP), São Carlos, SP, Brasil \\ Centro de Recursos Hídricos e Estudos Ambientais (CRHEA). E-mail: allita.santos@gmail.com, \\ mauadffm@sc.usp.br \\ ${ }^{2}$ Universidade de Uberaba (UNIUBE), Uberaba, MG, Brasil \\ Laboratório de Geoprocessamento.E-mail: renato.carneirofs@hotmail.com, leonardo.assis@uniube.br \\ *Corresponding author
}

\begin{abstract}
Environmental conservation of river basins in general is essential for water quality and ecological maintenance, especially in spring areas. Despite being characterized as a Conservation Unit (CU) of Sustainable Use (SU), the Uberaba River Basin highlands are highly influenced by anthropic activities. The aim of this study was to determine different levels of conservation required to maintain environmental quality. The Multicriteria evaluation method was used as follows: i) applied fuzzy membership functions to standardization of the continuous data values or reclassified when categorical criteria; (ii) established criteria ranking through the pairwise relative importance comparison approach by the Analytical Hierarchy Process (AHP) method and; (iii) performed Weighted Linear Combination (WLC). The selected criteria were maps of the: land cover obtained by supervised classification of a satellite image, with $94 \%$ of Kappa Index of Agreement (KIA); soil types, slope; distances from rivers, roads; railways and urban limits. A main outcome of the criteria evaluated is a map of continuous data values expressing distinct levels of environmental conservation requirements. The highest values that express the need for conservation occurred near the ridgetop, corresponding to forest land cover, high slope and hydromorphic soils. The lowest values were observed in the peri-urban areas, in more stable soil and soil cover with a higher degree of occupation. It is concluded that the resulting map can assist in decision-making regarding proper management of the area, to achieve sustainability in the application of occupation policies.
\end{abstract}

Keywords: environmental degradation, multicriteria, weights comparison.

\section{Definição dos níveis de conservação ambiental considerando a ocupação antrópica na área protegida da bacia hidrográfica do rio Uberaba}

\section{RESUMO}

A conservação ambiental das bacias hidrográficas em geral é essencial para a qualidade da água e manutenção ecológica, especialmente nas áreas de nascentes. Apesar de se caracterizar como uma Unidade de Conservação de Uso Sustentável, as terras altas da bacia do rio Uberaba 
são altamente influenciadas por atividades antrópicas. O objetivo deste estudo foi determinar diferentes níveis de conservação necessários para a manutenção da qualidade ambiental. Utilizou-se o método Avaliação Multicritérios segundo os passos: i) aplicação de funções de pertinência fuzzy para padronização dos valores de dados contínuos ou reclassificação quando critérios categóricos; ii) hierarquização dos critérios por comparação da importância relativa a partir do método Processo Analítico Hierárquico e; iii) realização da Combinação Linear Ponderada. Os critérios selecionados foram mapas de: cobertura do solo obtido por classificação supervisionada de imagem de satélite, com 94\% de índice estatístico Kappa, tipos de solo, declividade, distâncias a partir dos rios, estradas, ferrovia e limites urbanos. Um dos principais resultados dos critérios avaliados é um mapa de valores de dados contínuos que expressam níveis distintos de requisitos de conservação ambiental. Os maiores valores que expressam a necessidade de conservação ocorreram próximos ao divisor de águas, correspondendo a vegetação nativa, alta declividade e solos hidromórficos. Os menores valores foram observados nas áreas periurbanas, em solos mais estáveis e cobertura do solo com maior grau de ocupação. Conclui-se que o mapa resultante pode auxiliar na tomada de decisão quanto ao manejo adequado da área, visando a sustentabilidade na aplicação de políticas de ocupação.

Palavras-chave: comparação pareada, degradação ambiental, multicritérios.

\section{INTRODUCTION}

Human activities generate a set of impacts on aquatic ecosystems as a result of population, industry and world economy growth (Tundisi et al., 2003). This deterioration is related to growth and agricultural diversification, as well as the increase in urbanization and intensification of activities in the basin. The excessive use of the soil and water, deforestation and non-sustainable management, may be relate to water level decline, toxic contamination, eutrophication, acidification and material increase in suspension inside the water bodies. (Tundisi, 2005). This information reflects some of the complex interactions that are present in the environment.

The natural environment as a complex system must be analyzed under a multivariate perspective. In addition, sustainable management of natural resources also depends on the environmental conservation state of a river basin (Tundisi and Matsumura-Tundisi, 2014), since each unit has physical, ecological, economic and hydrological characteristics. In this sense, the studies related to environmental conservation should include, in addition to bio-geophysical characteristics of a system, other factors such as the influence of human activities on aquatic environments (Mishra and Rai, 2016). From this, the concept of environmental conservation approached in this study includes the main set of factors that promote, among other impacts, soil erosion. These factors are vegetative cover, slope, soil cover and soil types, allied to water bodies and road systems (Zhang et al., 2010; Vettorazzi and Valente, 2016).

The integrated vision can promote a good understanding of the negative impacts occurring in water bodies, considering the distinct nature of the factors that influence the environment. Thus, upon assigning values to the criteria of an environmental assessment, the alternatives that optimize the decision are prioritized (Franco et al., 2013). The criteria are standardized by fuzzy pertinence function, hierarchized by comparison in pairs and weighted according to the study purpose, in order to support the decision-making process of a Multi-criteria Evaluation (MCE) (Eastman, 2012; Franco et al., 2013; Montgomery et al., 2016).

Some studies with methodology similar to this identified priority areas for forest restoration (Vettorazzi and Valente, 2016), and for environmental conservation in relation to the erosion risk (Zhang et al., 2010), or evaluating suitable areas for agriculture (Montgomery et al., 2016); but studies considering the delimitation of protected areas by environmental 
legislation, e.g., conservation units for sustainable use in Brazil, should also be discussed and compared, including with other countries.

Considering the above, the environmental assessments with interleaved goals can be studied from tools such as Geographic Information Systems (GIS). Thus, the objective of this study is the definition of environmental conservation areas through suitability levels of natural fragility, considering anthropic occupation in the Environmental Protection Area (EPA) of the Uberaba River Basin (URB). In this way, the present study can contribute to sustainable management by public agencies and to decision making applied in spatial analysis for environmental conservation studies.

\section{MATERIALS AND METHODS}

\subsection{Study area}

The study area corresponds to the EPA of the Uberaba River Basin (EPA-URB) (Figure 1). It is in South America and the southern part of Brazil, Minas Gerais state and Uberaba city. With a population estimated at almost 330 thousand in the year 2017 (IBGE, 2017), the city is one of eight major cities of the state, and from a geo-economics standpoint has highly strategic viability due to its location approximately $500 \mathrm{~km}$ from the main capitals, in the center of one of the country's most important consumer markets (Uberaba, 2012).
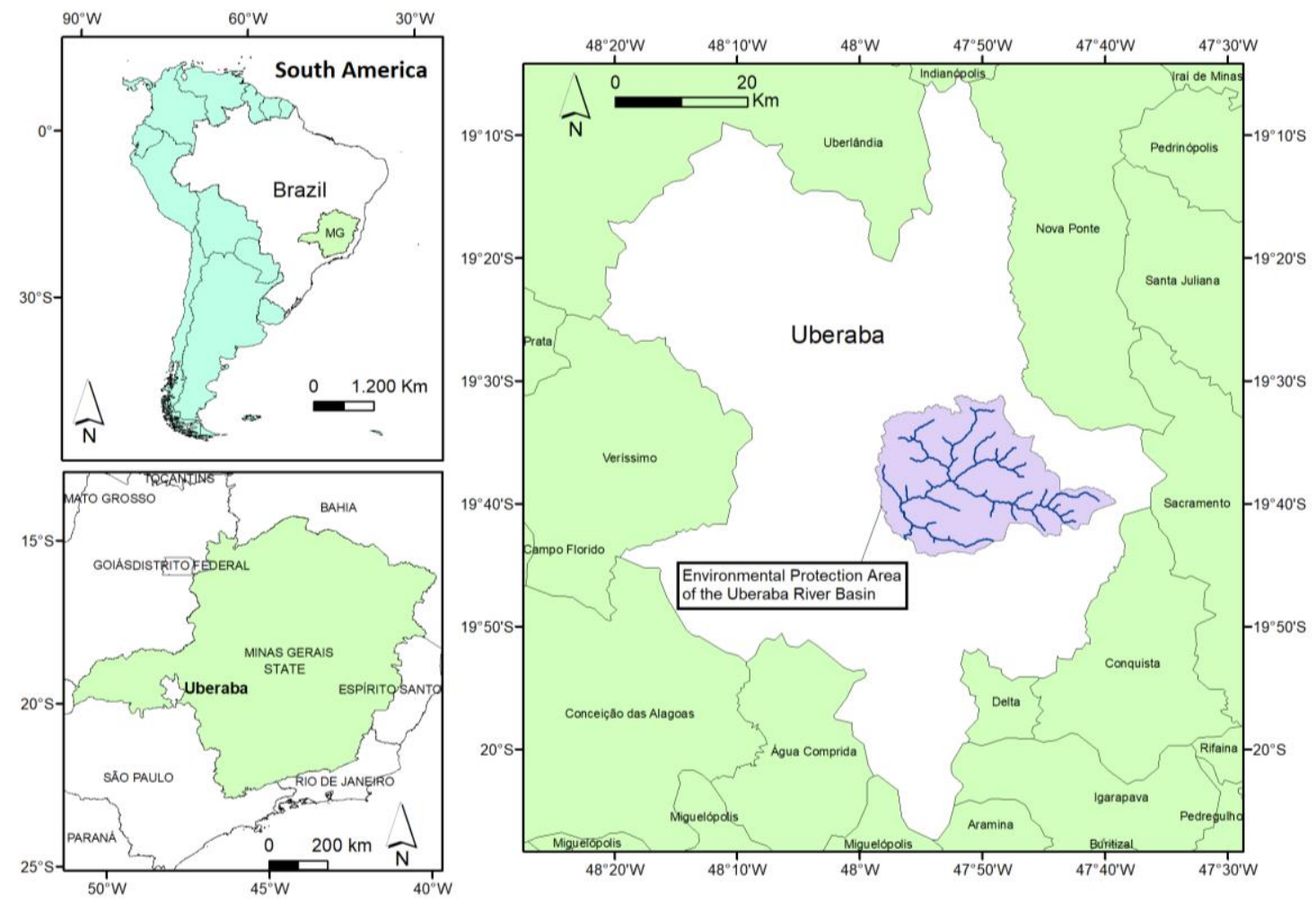

Figure 1. Geographic location of the EPA-URB.

The Uberaba River is part of the river basins Grande, Paraná and Plate (the second largest drainage basin in South America). It is valuable as a natural resource and for the supply of ecosystem services, especially in the economic aspects of agricultural activities and it is also the city's main water supply source (Uberaba, 2012). According to the Köppen climate classification, the rainfall regime is Aw, with rainy summer (October-March) and dry winter (May-September) and the average annual temperature in region is between $20^{\circ} \mathrm{C}$ and $22^{\circ} \mathrm{C}$ (Ribeiro et al., 2012).

\section{IPABH}


The EPA-URB (Figure 1) delimits the region of springs' protection and water recharge, located upstream of the city's water catchment point, with an area of approximately $530 \mathrm{~km}^{2}$, including $8 \%$ of urbanization (Uberaba, 2012). It was created by State Law Number 12.183 in 1999 and established limits and specific objectives through Municipal Law Number 9.892 in 2006 (Ribeiro et al., 2012).

The creation text of the EPA-URB includes reports about the emerging lithostratigraphic units throughout the CU influence area, as well as a comprehensive description of fossils discovered in these localities (Ribeiro, 2014). The soils present medium textures, with variations from clay to sandy soils, according to the Brazilian Soils Classification are classed as latosol of different fertility degrees, with dark-red latosol and dystrophic purple latosol predominating (Cruz et al., 2003).

\subsection{Conservation scenario by Multi-criteria Evaluation}

The proposed methodology involves the creation of an environmental conservation scenario with multicriteria evaluation tool support from IDRISI Selva software, adopting the necessary restrictions and factors (Miranda, 2010; Zhang et al., 2013; Costa et al., 2016; Valente et al., 2017). The main steps of the proposed multi-criteria evaluation are: factor standardization, hierarchy and aptitude map elaboration.

The only restriction used was the study area delimitation (binary image), as indicated in the law wording. It starts in the water catchment point for public supply and extends up to the divider limits of waters (ridgetop) in the upstream region. The drainage network, surface area and slope detection were extracted from the relief information of the Digital Elevation Model (DEM), obtained in the year 2015 by Advanced Spaceborne Thermal Emission and Reflection Radiometer (ASTER) and provided by the United States Geological Survey (USGS), in $30 \mathrm{~m}$ resolution (Costa et al., 2016).

\subsubsection{Factors standardization}

The factors have different data types (categorical or continuous) and therefore need to be standardized by means of reclassification or fuzzy logic application. Table 1 shows the factors according to the data type and corresponding standardization.

Table 1. Factors, data type and corresponding standardization factors.

\begin{tabular}{ccc}
\hline Factors & Data Type & Standardization Type \\
\hline Cover & Categorical & Reclassification \\
Soil & Categorical & Reclassification \\
Slope & Continuous & Fuzzy logic \\
DFRI & Continuous & Fuzzy logic \\
DFRO & Continuous & Fuzzy logic \\
DFRA & Continuous & Fuzzy logic \\
DFUL & Continuous & Fuzzy logic \\
\hline
\end{tabular}

Legend: DFRI $=$ Distance from rivers, DFRO $=$ Distance from roads, DFRA $=$ Distance from railway, DFUL $=$ Distance from urban limits.

This stage of the decision-making consists of the transformation of values of the original data into degrees of relevance ( 0 to 255 ), notably by means of fuzzy logic functions for continuous data, in this case the sigmoid monotonic function that determines the gradual change at the border among the phenomena, varying according to the adequacy levels in an interval (Miranda, 2010; Eastman, 2012; Zhang et al., 2013; Costa et al., 2016). 
The roads, railway and part of the urban limits belonging to the study area were scanned in cartographic scale of 1:15,000, on an GIS environmental. The conservation goals near the anthropic occupations are at higher disturbance, therefore, the distance of these areas increases the biodiversity protection level (Costa et al., 2016). Also included in the impact factors set considered important is the slope and distances from rivers, in a decreasing manner. This is because the higher the slope and the rivers' proximity, the greater must be the weight in relation to environmental conservation (Zhang et al., 2013)

The categorical type criteria are composed of classes, making it impossible the direct application of the fuzzy pertinence function. In this case, standardization occurs by operation of image value reclassification (0 to 255) (Oliveira et al., 2014). The relative importance of all factors was indicated and compensation was made among them, on account of their ecological function and the degradation processes arising from anthropic occupation with the literature support (Cruz et al., 2003). These were discussed by four technical specialists (Miranda, 2010; Eastman, 2012) in the areas of: environmental management; agricultural, civil and environmental engineering and their experience with sedimentometry, hydrology and geoprocessing.

The ecological function of the categorical data factors was considered, e.g., the role of native vegetation in controlling the input of sediments in water bodies and springs, especially when it comes to riparian forest, in addition to improving the local ecosystem by biological interactions (vegetation-soil-water) (Tundisi and Matsumura-Tundisi, 2014), and the role of hydromorphic soils in the water table recharge, and soils considered little anthropized or that suffered moderate weathering (Lepsch, 1993; EMBRAPA, 2013).

The degradation processes arising from anthropic occupation was considered, e.g., the critical changes of natural vegetation and the development of activities that negatively impact the environment (Zhang et al., 2013; Calijuri et al., 2015; Costa et al., 2016).

\subsubsection{Soil cover standardization}

Notably, the soil cover map was prepared based on the images' supervised classification procedure, using the Maximum Likelihood algorithm and accuracy was assured by the KIA statistical index (Poznanovic et al., 2014; Calijuri et al., 2015; Varga et al., 2015; Mishra and Rai, 2016). The image used was from Landsat 8 , in the bands of the Operational Land Imager (OLI) sensor, dated September 03rd 2017, provided by the Division of Image Generation (DGI) of the National Institute for Space Research (Instituto Nacional de Pesquisas Espaciais - INPE).

The classes of soil cover in the region and the respective standardization values, are:

(i) Anthropized area - value 0; basically in urban limits and exposed soil. The lowest standardization value, corresponding to critical changes of natural vegetation (Zhang et al., 2013; Costa et al., 2016);

(ii) agricultural area - value 80; the predominant agriculture under study is sugarcane, maize, soy and horticulture;

(iii) pastures - value 150; the pastures make the soil have a higher density than that which has not been cultivated, cattle-breeding leads to soil trampling and wear, where the management type can directly influence the soil compaction process, potentiating susceptibility to erosion (Uberaba, 2012), possibly responsible for the sedimentation formed and deposited in the riverbeds. A pasture without proper management can be a serious environmental problem, reflected in the case of degraded pastures (Dias-Filho, 2014). A study conducted in all of the Uberaba River Basin, by Valera et al. (2016), reported that since 1964 the landscape has changed significantly, and the native vegetation cover has been removed, being replaced by managed pastures used for livestock production; 
(iv) native vegetation - value 255; experts in ecology and nature conservation consider the vegetation as the most important criterion in the case of protected areas (Zhang et al., 2013). The plant cover is important in reducing erosion (Tundisi et al., 2003), determines the soil vulnerability, as well as the quali-quantitative increase of water, where the surface porosity and moisture absorption originated in the root system, depletes the water content in the soil by increasing the infiltration rate in the soil matrix (Biswas, 1976; Lepsch, 1993).

\subsubsection{Soil-type standardization}

The soil types (Table 2) map was obtained from Geoprocessing Laboratory database of the Uberaba University (UNIUBE). According to the Brazilian Soils Classification, the standardization values are laid down as follows:

Table 2. The EPA-URB soil types and respective standardization values.

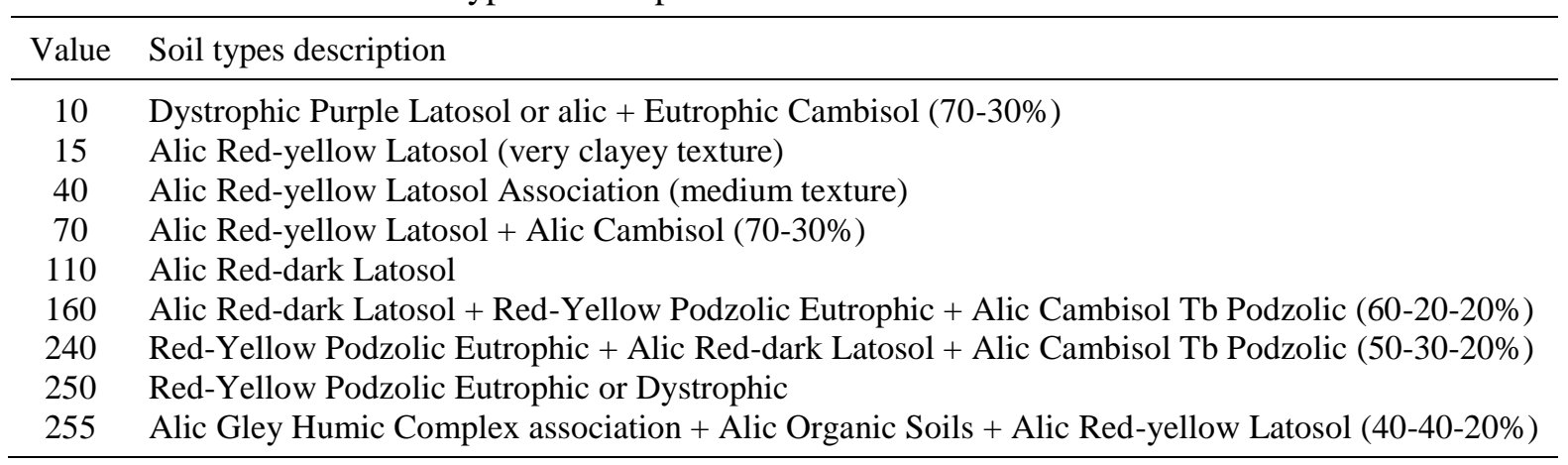

Source: Adapted from Cruz et al. (2003).

The standardization values were identified according to the main physical factors of soils and respective natural conservation characteristics together with the vulnerability (Costa et al., 2016; Vettorazzi and Valente, 2016). Scientific literature support was used for the texture, temperature/heat, aeration, infiltration capacity, water retention and structure (Lepsch, 1993). The properties considered as having influence on soil fragility are the flow, soluble salts, nutrient movement and oxygen in the soil, evapotranspiration, including the effects of dryness on the soil-plant-water system, and finally, reductions in sediment transport according to spacetime variability of soil properties (Scott, 2000).

The Latosol-type soil wase classified with low conservation values. It is considered an old soil that is stable and has been subjected to intense weathering. It is deep and most of the time impoverished in nutrients necessary to plants, under sparse vegetation (Lepsch, 1993).

The Podzolic-type soil was identified with high standardization values. It is from humid climate forest regions, with a well-developed profile, moderately impacted by weathering (EMBRAPA, 2013). It are in a shallower depth, and in situations of more rugged relief are found natural vegetation such as forests of broadleaf trees, and is considered very susceptible to water erosion (Lepsch, 1993).

The hydromorphic soils were standardized with the highest values. The Alic Humic Gley soil type is that which develops with the influence of high groundwater acting as areas of water table recharge, and the characteristics are dark, almost black, very soft and porous (Lepsch, 1993; EMBRAPA, 2013). In these regions, depressions are found that support the outcropping of groundwater, giving rise to some of the diffuse springs of Uberaba River, and in the surroundings are found differentiated geomorphological conformations where the "covoais" occur, which are clay mounds spread and colonized by small trees and shrubs (Uberaba, 2012). 


\subsection{Hierarchization of the factors}

The Analytical Hierarchy Process, widely cited in the specialized technique literature, was adopted (Oliveira et al., 2014) to compare the factors in pairs and then assign weights to each one (Miranda, 2010; Eastman, 2012; Costa et al., 2016; Valente et al., 2017). At the end of the comparison, the inconsistency in the process is verified through the Consistency Ratio (CR) (Saaty, 1987; Miranda, 2010). Once a tolerance value below 0.1 is obtained, it is possible to finalize the comparison and calculate the weights of each factor to be used in the MCE (Miranda, 2010; Vettorazzi and Valente, 2016).

\subsection{Aptitude map}

As a result, a map of aptitude to environmental conservation was obtained through the creation of a Weighted Linear Combination scenario (Miranda, 2010; Eastman, 2012; Costa et al., 2016; Valente et al., 2017). In this phase, the multiplication of each factor occurs (each pixel on the map) by its weight, then the sum of the results (Sartori et al., 2012).

\section{RESULTS AND DISCUSSION}

The EPA-URB soil cover map (Figure 2) demonstrated that the predominant activity is pasture, corresponding to $170 \mathrm{~km}^{2}$ and $34 \%$ of the study area. Candido et al. (2010), made the field recognition of the Uberaba River Basin vulnerability. The authors pioneered works with parameters of environmental degradation to group the methodologies found in spatial analysis and observed an extensive pasture area in the north of the basin (EPA-URB). Valera et al. (2016) conducted a field campaign to collect soil samples in the basin of the Uberaba River, aiming to verify the interference of soil use and occupation in the qualitative analysis of the samples. The study of Valera et al. (2016) also identify pasture as a predominant activity in the northern part of the Uberaba River Basin, showing that spatial analysis demonstrated in the present study and in the study of Candido et al. (2010) was satisfactory when compared to the field sampling.

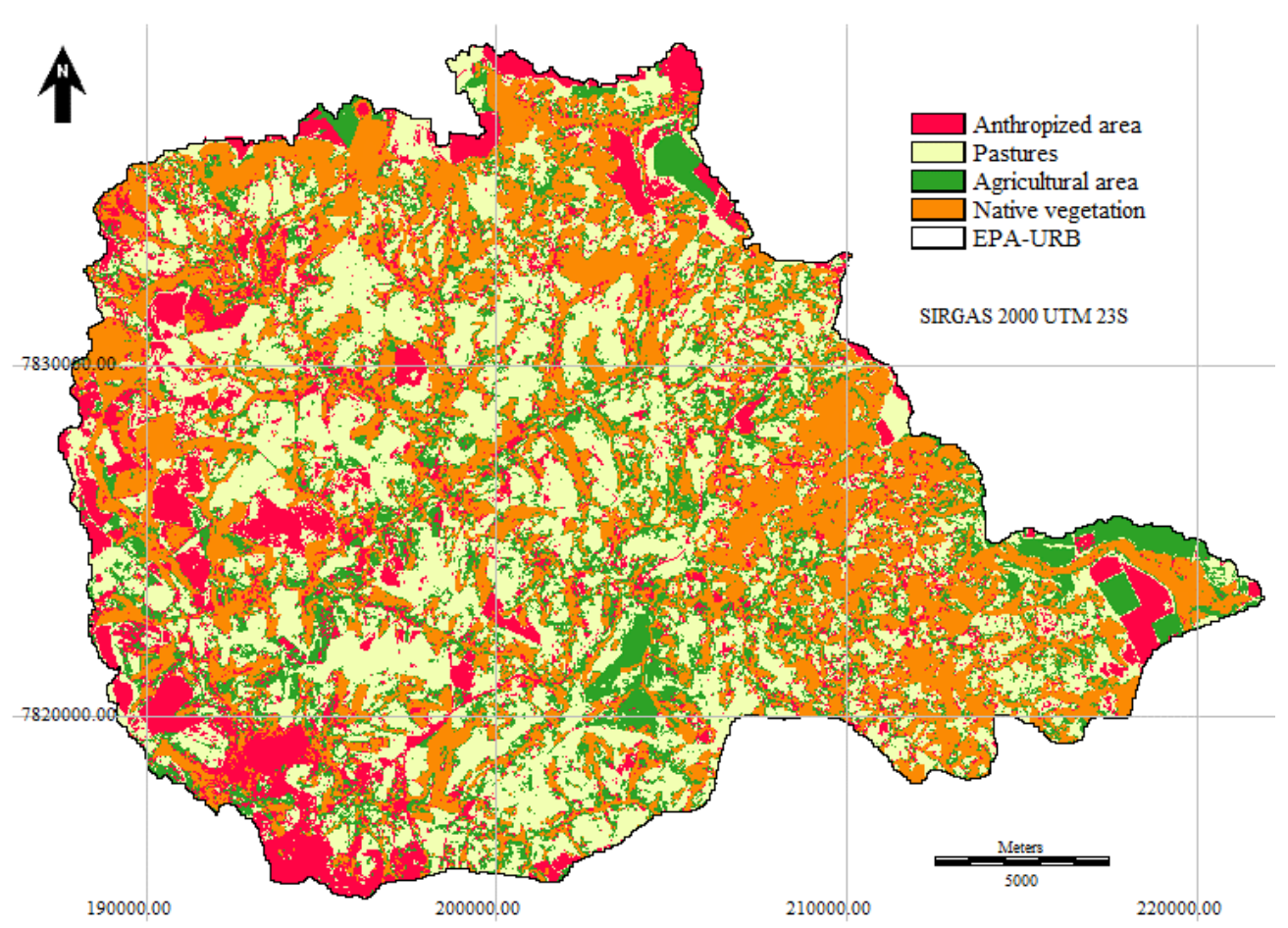

Figure 2. Land cover map of the EPA-URB, prepared based on the images supervised classification procedure. 
A study was carried out in a river basin located in Central-Eastern region of São Paulo state (Brazil) approximately $1,700 \mathrm{~km}^{2}$ in size, that is a strategic water source (Vettorazzi and Valente, 2016). The authors used the supervised classification to obtain the soil cover of the region and found that the human intervention was responsible for forest deforestation in parts. The predominant activities that occupy the region are pasture and sugarcane, occupying respectively $43 \%$ and $28 \%$ of the basin. In the present study, environmental changes were identified by pasture, agricultural (sugarcane), anthropized area and native vegetation, respectively, with 34\%, 18\%, 18\% and 30\% (approximately 94\% of thematic accuracy). The area studied by Vettorazzi and Valente (2016), is larger than that of the present study; however, the similarity found in both studies demonstrates that pasture and agriculture activities are responsible for deforestation in regions of the two states, among other activities. In addition, the classification technique used in both was the same, demonstrating it to be efficient for different regions.

The native vegetation areas which are still preserved (Figure 2) are arranged in scattered fragments, but the surroundings are taken by agriculture and anthropized area (exposed soil, probably in preparation for cultivation). This also was verified before, according Candido et al. (2010), by means of a typical example of soil use conflict in which the sugarcane crop advances to the spring areas of the Uberaba River (EPA-URB). Given this, the increase of the environmental changes caused by human occupation can occur if adequate management does not oversee land use. This condition reflects the need to apply decisive strategies to ensure the conservation of the area with the establishment of environmental policies aimed at the control of anthropic occupation, based on updated Management Plans (Brasil, 2000).

Table 3 shows that slope, soil types, soil cover and road distances were the most important factors for the results obtained in the environmental conservation map (Figure 3), with a 3\% inconsistency in the comparison process through the RC. Vettorazzi and Valente (2016) studied forest restoration for water conservation using the Analytical Hierarchy Process. In the elaboration of the influence factors, the following variables were incorporated: i) the incorrect association of land use, soil type and relief in land use adequacy factor; ii) soil type intrinsic characteristics in erodibility factor; and iii) factor of proximity to roads. These factors obtained high weights in the hierarchical process. Although the variables were incorporated in the factors elaborated by Vettorazzi and Valente (2016) and considered separately in the present study, both results obtained high weights for the slope, soil types, soil cover and roads distances. The associations among these criteria are fundamental to establish the susceptibility of erosive processes (Lepsch, 1993; Scott, 2000; Uberaba, 2012; Zhang et al., 2013), for environmental conservation and forest restoration, aiming at improving the quality and availability of water.

Table 3. Pared comparison of the factors and the respective weights obtained in the AHP.

\begin{tabular}{lcccccccc}
\hline Criteria & Cover & Soil & Slope & DFRI & DFRO & DFRA & DFUL & Weights \\
\hline Cover & 1 & & & & & & & 0,1946 \\
Soil & $1 / 3$ & 1 & & & & & & 0,1764 \\
Slope & $1 / 3$ & 1 & 1 & & & & & 0,2186 \\
DFRI & $1 / 5$ & $1 / 3$ & $1 / 3$ & 1 & & & & 0,0635 \\
DFRO & $1 / 3$ & $1 / 3$ & 3 & 5 & 1 & & & 0,1553 \\
DFRA & $1 / 5$ & $1 / 5$ & $1 / 3$ & 1 & $1 / 3$ & 1 & & 0,0451 \\
DFUL & $1 / 5$ & $1 / 5$ & $1 / 5$ & $1 / 5$ & $1 / 3$ & $1 / 3$ & 1 & 0,1465 \\
\hline
\end{tabular}

Legend: DFRI $=$ Distance from rivers, DFRO $=$ Distance from roads, DFRA $=$ Distance from railway, DFUL $=$ Distance from urban limits. 
Zhang et al. (2013) used a participatory process of environmental zoning in the study of protected areas in China. The authors observed that the Analytical Hierarchy Process resulted in greater weight factor for the isolated class of vegetation and environmental conservation targets. Similarly, in the present study the variable native vegetation is incorporated in the soil cover factor with the highest standardized importance in ratio to the other classes of soil cover. This demonstrates that the delimitation of the protected areas is a determinant factor for native vegetation conservation.

The area covered by native vegetation found in this study does not exceed $30 \%$ of the total area, which may influence the decline of the river water level in dry periods (Tundisi, 2005; Zhang et al., 2013; Calijuri et al., 2015;), and consequently affect the water supply of the municipality. The low river flow (water stress) promotes the need of system activation of transposition of another river in the region, and this increases the costs for the population (CODAU, 2017). The processes of environmental degradation that affect the availability and water quality of the water bodies are due to changes in vegetation and to the region's physical characteristics.

The environmental conservation map (Figure 3) shows the highest levels of environmental conservation priority in the region have been identified in the areas of springs and hydromorphic soils, where the "covoais" are located, which have great ecological importance for the hydrological cycle of the region (Uberaba, 2012). Therefore, it is recommended that the priority areas for conservation be incorporated in the Water Producer Program to provide technical support and payment for environmental services (ANA, 2012). Thus, the rural producers are encouraged to invest in conservation practices of water, soil and vegetation.

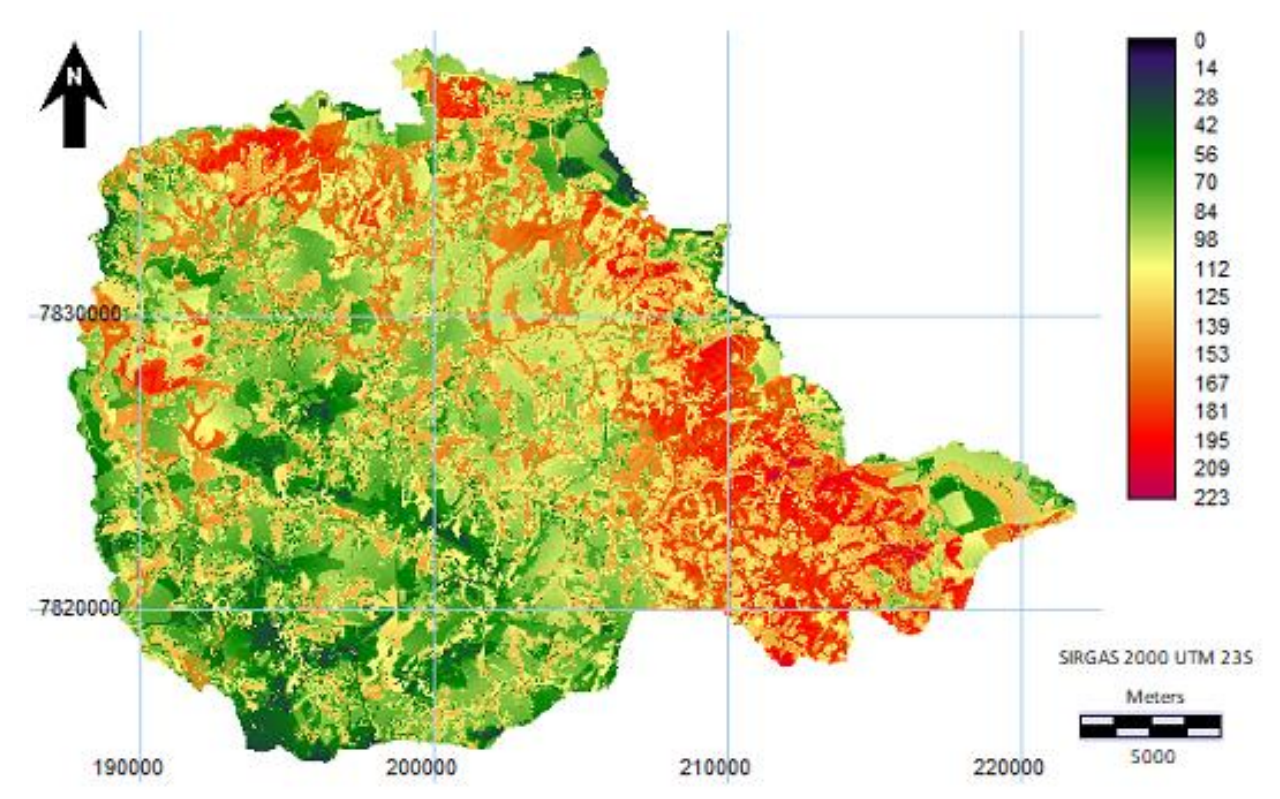

Figure 3. Environmental conservation levels of the EPA-URB, by MCE method.

The maximum value of conservation priority found was 223, probably due to the compensation among the established criteria. In general, the best results of conservation adequacy were found in the proximity of the higher values of relief, slope, occupation by native vegetation and presence of hydromorphic soils. In the study by Ioana-Toroimac et al. (2017), priority rivers were identified for hydromorphological restoration in Romania based on multicriteria evaluation. The factors were designed to recognize human pressures, channel changes and fluvial functionality. In the present study, the values resulted from low- to medium levels of conservation in general, even in the regions closer to the water bodies. Therefore, the factors elaborated by Ioana-Toroimac et al. (2017), if adapted to the factors considered in the present 
study, can present considerable levels of environmental conservation near the water bodies. This is a suggestion for future works.

Areas with high slopes are located in the northern regions. This leads to the potential of surface runoff generated by heavy rains, favoring the formation of trench erosions at some points (Lepsch, 1993; Scott, 2000; Uberaba, 2012; Zhang et al., 2013). Candido et al. (2010), in a study in the same basin as the present study observed that the anthropic occupation reached areas protected by law. The authors identified a moderate to severe level of environmental degradation in EPA-URB, evidencing signs of exhaustion of natural resources. The study of Candido et al. (2010) and the present study suggest that soil degradation should be continuously monitored by evaluating environmental conservation and anthropic occupation.

\section{CONCLUSIONS}

In this study, a map was developed containing the environmental conservation levels considering environmental factors and their changes due to human activities in the EPA-URB. Areas with higher priority were identified in plots of native vegetation, floodplains, hydromorphic soils, water recharge sites, high slopes, "covais" and springs. These are areas of extreme importance for the maintenance of water resources and their conservation is a priority for local demand for water supply.

It is concluded that the established criteria, the standardization and the obtaining of weights for the multi-criteria evaluation, allowed a consistent analysis in relation to the levels of priority to environmental conservation. In addition, the generated map can help in decision making for the adequate management of the region's sustainability, by the managers in the management plan elaboration.

The proposed methodology (multi-criteria evaluation) can be applied if specialists are available, both in the technical area of hydrology, sedimentometry and environmental management, as well as in the treatment of spatial information. This tool is used to elaborate adequate maps and to identify critical areas and zoning.

\section{REFERENCES}

AGÊNCIA NACIONAL DE ÁGUAS - ANA (Brasil). Manual operativo do programa produtor de água. 2. ed. Brasília, 2012. 92p.

BISWAS, A. K. Water Resources: Environmental Planning, Management, and Development.New York: McGraw-Hill, 1976. 737p.

BRASIL. Lei $n^{\circ}$ 9.985, de 18 de julho de 2000. Regulamenta o art. 225, $\S 1^{\circ}$, incisos I, II, III e VII da Constituição Federal, institui o Sistema Nacional de Unidades de Conservação da Natureza e dá outras providências. Diário Oficial [da] União: seção 1, Brasília, DF, jul. 2000 .

CALIJURI, M. L.; CASTRO, J. de S.; COSTA, L. S.; ASSEMANY, P. P.; ALVES, J. E. M. Impact of land use/land cover changes on water quality and hydrological behavior of an agricultural subwatershed. Environmental Earth Sciences, v. 74, n. 6, p. 5373-5382, 2015. https://doi.org/10.1007/s12665-015-4550-0

CANDIDO, H. G.; GALBIATTI, J. A.; PISSARRA, T. C. T.; MARTINS FILHO, M. V. Degradação ambiental da bacia hidrográfica do rio Uberaba: uma abordagem metodológica. Engenharia Agrícola, Jaboticabal, v. 30, n. 1, p. 179-192, fev. 2010. http://dx.doi.org/10.1590/S0100-69162010000100019 
CENTRO OPERACIONAL DE DESENVOLVIMENTO E SANEAMENTO DE UBERABA - CODAU. Abastecimento Rio Uberaba. 2017. Available in: http://www.codau.com.br/noticiaDetalhe.php?codigo=5000040. Access on: 20 Feb. 2018.

COSTA, T. de O.; ASSIS, L. R. de; CALIJURI, M. L.; ASSEMANY, P. P.; LIMA, G. S. Defining Priority Zones for Conservation and Ecotourism in a Protected Area. Revista Árvore, v. 40, n. 5, p. 769-779, 2016. http://dx.doi.org/10.1590/010067622016000500001

CRUZ, L. B. S.; PATERNIANI, J. E. S.; CARVALHO, R. M. B. Caracterização e manejo sustentável do solo na bacia do Rio Uberaba (MG). Caminhos de Geografia, v. 4, n. 9, p. 31-49, 2003.

DIAS-FILHO, M. B. Diagnóstico das Pastagens no Brasil. Belém, PA: Embrapa Amazônia Oriental, 2014. 37p.

EASTMAN, J. R. IDRISI Selva Manual. 17. ed. Worcester: IDRISI Production, 2012. 322p.

EMPRESA BRASILEIRA DE PESQUISA AGROPECUÁRIA - EMBRAPA. Sistema brasileiro de classificação de solos. 3. ed. Brasília, DF: Embrapa Informação Tecnológica, 2013. 342p.

FRANCO, R. A. M.; HERNANDEZ, F. B. T.; MORAES, J. F. L. DE. O uso da análise multicritério para a definição de áreas prioritárias a restauração de Área de Preservação Permanente (APP), no noroeste paulista. In: SIMPÓSIO BRASILEIRO DE SENSORIAMENTO REMOTO, 16., abril 2013, Foz do Iguaçu, PR. Anais [...]. São José dos Campos: INPE, 2013. p. 3366-3373.

INSTITUTO BRASILEIRO DE GEOGRAFIA E ESTATÍSTICA - IBGE. Censo demográfico: Panorama - População (Uberaba). 2017. Available in: http://cidades.ibge.gov.br/xtras/perfil.php?codmun=317010. Access on: 20 Feb. 2018.

IOANA-TOROIMAC, G.; ZAHARIA, L.; MINEA, G.; MOROȘANU, G.A. Using a multicriteria analysis to identify rivers with hydromorphological restoration priority: Braided rivers in the south-eastern Subcarpathians (Romania). Science of The Total $\begin{array}{llllll}\text { Environment, } & \text { v. } & 599-600, & \text { p. } & 700-709,\end{array}$ https://doi.org/10.1016/j.scitotenv.2017.04.209

LEPSCH, I. F. Solos: formação e conservação. 5. ed. São Paulo: Prisma, 1993. 157p.

MIRANDA, J. I. Fundamentos de sistemas de informações geográficas. 2. ed. Brasília: Embrapa Informação Tecnológica, 2010. 433p.

MISHRA, V. N.; RAI, P. K. A remote sensing aided multi-layer perceptron-Markov chain analysis for land use and land cover change prediction in Patna district (Bihar), India. Arabian Journal of Geosciences, v. 9, n. 4, p. 249, 2016. https://doi.org/10.1007/s12517-015-2138-3

MONTGOMERY, B.; DRAGIĆEVIĆ, S.; DUJMOVIĆ, J.; SCHMIDT, M. A GIS-based Logic Scoring of Preference method for evaluation of land capability and suitability for agriculture. Computers and Electronics in Agriculture, v. 124, p. 340-353, 2016. https://doi.org/10.1016/j.compag.2016.04.013 
OLIVEIRA, F. B. de; OLIVEIRA, C. H. R. de; LIMA, J. S. de S.; MIRANDA, M. R.; RIBEIRO FILHO, R. B.; TURBAY, E. R. M. G. et al. Definição de áreas prioritárias ao uso público no parque estadual da Cachoeira da Fumaça - ES, utilizando geoprocessamento. Revista Árvore, v. 38, n. 6, p. 1027-1036, 2014. http://dx.doi.org/10.1590/S010067622014000600007

POZNANOVIC, A. J.; FALACIOSO, M. J.; MACLEAN, A. L.; SMITH. A. M. S; EVANS, J. S. An Accuracy Assessment of Tree Detection Algorithms in Juniper Woodlands. Photogrammetric Engineering \& Remote Sensing, v. 80, n. 5, p. 627-637, 2014. https://doi.org/10.14358/PERS.80.7.627

RIBEIRO, L. C. B.; TREVISOL, A.; CARVALHO, I. de S.; MACEDO NETO, F.; MARTINS, L. A. et al. Geoparque Uberaba - Terra dos Dinossauros do Brasil (MG): proposta. Uberaba, MG: CPRM, 2012. p. 583-616.

RIBEIRO, L. C. B. Geoparque Uberaba - Terra dos Dinossauros do Brasil. 2014. 124p. Thesis (Doctorate in Sciences, Geology) - Instituto de Geociências, Universidade Federal de Rio de Janeiro, Rio de Janeiro, 2014.

SAATY, R. W. The Analytic Hierarchy Process: What It Is and How It Is Used. Mathematical Modelling, v. 9, n. 3, p. 161-176, 1987. https://doi.org/10.1016/0270-0255(87)90473-8

SARTORI, A. A. da C.; SILVA, R. F. B. da; ZIMBACK, C. R. L. Weighted linear combination of a GIS environment in the definition of priority areas for connectivity among forest fragments. Revista Árvore, v. 36, n. 6, p. 1079-1090, dez. 2012. http://dx.doi.org/10.1590/S0100-67622012000600009

SCOTT, H. D. Soil Physics: Agricultural and Environmental Applications. 1. ed. Iowa: Iowa State University Press, 2000. 421p.

TUNDISI, J. G. Água no século XXI: enfrentando a escassez. 2. ed. São Carlos: Rima, 2005. $256 \mathrm{p}$.

TUNDISI, J. G.; MATSUMURA-TUNDISI, T. The ecology of UHE Carlos Botelho (LoboBroa Reservoir) and its watershed, São Paulo, Brazil. Freshwater Reviews, Washington, v. 6, n. 2, p. 75-91, 2014. https://doi.org/10.1608/FRJ-6.2.727

TUNDISI, J. G.; MATSUMURA-TUNDISI, T.; RODRIGUES, S. L. Gerenciamento e Recuperação das Bacias Hidrográficas dos Rios Itaquerí e do Lobo e da UHE Carlos Botelho (Lobo-Broa). São Carlos: IEE/IIEGA, 2003. 55p.

UBERABA. Secretaria de Meio Ambiente e Turismo. Plano de manejo emergencial: área de proteção ambiental municipal do rio Uberaba. Uberaba: Centro Operacional de Desenvolvimento e Saneamento de Uberaba, 2012. 153p.

VALENTE, R. A.; PETEAN, F. C. de S.; VETTORAZZI, C. A. Multicriteria Decision Analysis for Prioritizing Areas for Forest Restoration. CERNE, v. 23, n. 1, p. 53-60, 2017. http://dx.doi.org/10.1590/01047760201723012258

VALERA, C. A.; VALLE JUNIOR, R. F.; VARANDAS, S. G. P.; SANCHES FERNANDES, L. F.; PACHECO, F. A. L. The role of environmental land use conflicts in soil fertility: A study on the Uberaba River basin, Brazil. Science of The Total Environmental, v. 562, p. 463-473, 2016. https://doi.org/10.1016/j.scitotenv.2016.04.046 
VARGA, K.; SZABÓ, S.; SZABÓ, G.; DÉVAI, G.; TÓTHMÉRÉSZ, B. Improved land cover mapping using aerial photographs and satellite images. Open Geoscience, v. 7, p. 15-26, 2015. https://doi.org/10.1515/geo-2015-0002

VETTORAZZI, C. A.; VALENTE, R. A. Priority areas for forest restoration aiming at the conservation of water resources. Ecological Engineering, v. 94, p. 255-267, 2016. https://doi.org/10.1016/j.ecoleng.2016.05.069

ZHANG, Z.; SHERMAN, R.; YANG, Z.; WU, R. WENLI, W. YIN, M. YANG, G.; OU, X. Integrating a participatory process with a GIS-based multi-criteria decision analysis for protected area zoning in China. Journal for Nature Conservation, v. 21, n. 4, p. 225240, 2013. https://doi.org/10.1016/j.jnc.2012.12.006

ZHANG, X.; WU, B.; LING, F.; ZENG, Y.; YAN, N.; YUAN, C. Identification of priority areas for controlling soil erosion. CATENA, v. 83, n. 1, p. 76-86, 15 out. 2010. https://doi.org/10.1016/j.catena.2010.06.012 


Ambiente \& Água - An Interdisciplinary Journal of Applied Science
ISSN 1980-993X - doi:10.4136/1980-993X
www.ambi-agua.net
E-mail: ambi.agua@gmail.com

\title{
Physico-chemical variability and heavy metal pollution of surface sediment in a non-channeled section of Dilúvio Stream (Southern Brazil) and the influence of channeled section in sediment pollution
}

\author{
ARTICLES doi:10.4136/ambi-agua.2285 \\ Received: 01 Jun. 2018; Accepted: 01 Nov. 2018
}

\author{
Pedro Alexandre Sodrzeieski ${ }^{\text {iD }}$ Leonardo Capeleto de Andrade*iD; \\ Tales Tiecher $\mathbb{D}^{\circ}$; Flávio Anastácio de Oliveira Camargo $(\mathbb{D}$ \\ Universidade Federal do Rio Grande do Sul (UFRGS), Porto Alegre, RS, Brasil \\ Departamento de Solos (DS).E-mail: pedroasod@gmail.com, eng.capeleto@gmail.com, \\ tales.tiecher@gmail.com, fcamargo@ufrgs.br \\ *Corresponding author
}

\begin{abstract}
Dilúvio Stream flows through an area with a great population density in Porto Alegre, Southern Brazil. The anthropogenic influence in the surroundings impacted negatively the quality of the sediments of Dilúvio Stream and Lake Guaíba. This study evaluated the physicochemical variability of surface sediments in a non-channeled section of Dilúvio Stream. Additionally, we compared the concentration of several heavy metals in this section with data from previous studies in the margins of Lake Guaíba near the outflow of Dilúvio Stream in order to evaluate the impact of urbanization on sediment pollution. The $\mathrm{pH}$, bulk density, particle-size distribution, electrical conductivity, organic carbon, assimilable phosphorus, total nitrogen, mineralogical composition (X-ray diffractogram) and pseudo total concentration of several metals ( $\mathrm{Fe}, \mathrm{Al}, \mathrm{Ca}, \mathrm{Mg}, \mathrm{Na}, \mathrm{K}, \mathrm{Mn}, \mathrm{Ba}, \mathrm{Zn}, \mathrm{V}, \mathrm{As}, \mathrm{Pb}, \mathrm{Cu}, \mathrm{Cr}, \mathrm{Co}, \mathrm{Ni}, \mathrm{Cd}, \mathrm{Mo}$, and $\mathrm{Se}$ ) were evaluated. The results showed that the sediments in the non-channeled section of Dilúvio Stream are predominantly sandy, with heavy metal contents below the quality reference values. Quartz and feldspar predominated in all sites. The concentration of $\mathrm{Zn}, \mathrm{Pb}, \mathrm{Cu}, \mathrm{Cr}$, and $\mathrm{Ni}$ were lower than that observed in the margins of Lake Guaíba near the outflow of Dilúvio Stream, possibly due to pollution input throughout the channeled section. The Dilúvio Stream shows indications of an anthropogenic influence in the heavy metals concentration through the channeled area.
\end{abstract}

Keywords: metals, sediment contamination, urban pollution.

\section{Variabilidade físico-química e poluição por metais pesados em trecho não canalizado do Arroio Dilúvio (RS) e a influência do trecho canalizado na poluição dos sedimentos}

\section{RESUMO}

O Arroio Dilúvio percorre uma área com grande densidade populacional em Porto Alegre, sul do Brasil. A influência antrópica no entorno impacta negativamente na qualidade dos sedimentos do Arroio Dilúvio e do Lago Guaíba. O objetivo do trabalho foi avaliar a variabilidade físico-química em sedimentos superficiais do Arroio Dilúvio. Adicionalmente, 
comparou-se a concentração de vários metais na seção com estudos prévios das margens do Lago Guaíba, próximo à foz do Dilúvio, para avaliar o impacto da urbanização na poluição dos sedimentos por metais pesados. Avaliou-se $\mathrm{pH}$, densidade aparente, granulometria, condutividade elétrica, carbono orgânico, fósforo assimilável, nitrogênio total, composição mineralógica (difratometria de raio X) e concentração pseudo total diversos metais ( $\mathrm{Fe}, \mathrm{Al}, \mathrm{Ca}$, $\mathrm{Mg}, \mathrm{Na}, \mathrm{K}, \mathrm{Mn}, \mathrm{Ba}, \mathrm{Zn}, \mathrm{V}, \mathrm{As}, \mathrm{Pb}, \mathrm{Cu}, \mathrm{Cr}, \mathrm{Co}, \mathrm{Ni}, \mathrm{Cd}$, Mo e Se). Os resultados demonstram que os sedimentos são predominantemente arenosos, com níveis de poluição por metais pesados abaixo dos valores de referência de qualidade. Quartzo e feldspato predominaram em todos os pontos. A concentração de $\mathrm{Zn}, \mathrm{Pb}, \mathrm{Cu}, \mathrm{Cr}$ e Ni foram menores do que as observadas nas margens do Lago Guaíba próximos a foz do Dilúvio, possivelmente devido à presença de fontes de poluição na área canalizada. O Arroio Dilúvio mostra indicações de influência antrópica na concentração de metais pesados através da área canalizada.

Palavras-chave: contaminação de sedimentos, metais, poluição urbana.

\section{INTRODUCTION}

Anthropogenic activities are a major source of contaminants and heavy metal pollution (Zhang et al., 2016). Sediments can act as a reservoir of pollutants or interact directly with the environment, thus being an important indicator of the effects caused by pollution and human activities. Water bodies and sediments suffer impacts from many sources such as industrial activities, traffic, urban areas, agriculture, and can carry pollutants to other sites (Jartun et al., 2008; Sharley et al., 2016; Zhang et al., 2016).

Impermeable urban surfaces lead to serious problems such as an increase in runoff, flood risks, and lower water percolation, which results in drainage water directly into the rivers and lakes (Pigneret et al., 2016). Materials accumulated on impermeable surfaces are easily eroded during heavy rainfall and can be transported by suspension through the urban environment along with the pollutants which are at risk of being removed in the process (Jartun et al., 2008). Many sediments are formed in the roads, buildings areas, and are possibly linked to heavy metals and hydrocarbons, being easily transported by rainwater (Jartun et al., 2008; Pigneret et al., 2016).

Heavy metals are very common pollutants in urban areas, having global importance due to their risk to human and environment health, because of their persistence, bioavailability and toxicity (Pigneret et al., 2016; Sharley et al., 2016). Heavy metals in sediments are a common problem in urbanized areas marked by rapid population growth, industrial activities, and roads; having the tendency to increase diffuse sources of sediment pollution along with the increase of urban area in a drainage basin (Jartun et al., 2008; Sharley et al., 2016).

Erosion and siltation are also processes that may interfere with the sediment pollution and the impact along the channeled area. These processes take part with an imbalance between the water and sediment, occasioning problems in water and sediment quality and the diminution of the channel; alterations caused by human activities could influence these processes and alter their intensity (Yuan et al., 2018).

Dilúvio Stream is a small urban river located in Porto Alegre City, the capital of the State of Rio Grande do Sul in Brazil, with sources in the park Saint-Hilaire, in Viamão City (the neighboring city) and the outflow in Lake Guaíba, which is the main source of water supply for Porto Alegre City. Dilúvio's sub-basin, part of the Lake Guaíba drainage basin, is densely populated with about 446,000 inhabitants, suffering many effects from the disordered population growth and rapid industrialization in Porto Alegre, and lack of investments in basic sanitation (Mog et al., 2014). In addition, this region has large waterproofed areas and buildings in its surroundings, as well as the channeling and rectification of the stream with the 
construction of Ipiranga Avenue (one of the busiest in the city) in a large section (almost $12 \mathrm{~km}$ ) of its course.

The surrounding anthropic influence negatively impacts the sediment quality of Dilúvio Stream and Lake Guaíba. The environmental impacts occur mainly in the channeled part of the stream, with lower anthropic impact, where information of physico-chemical characteristics is lacking. Thus, the aim of this study was to evaluate the physico-chemical variability of surface sediments in a non-channeled section of Dilúvio Stream. Additionally, we compared the concentration of several metals in this section with data from previous studies carried out in the margins of Lake Guaíba near the outflow of Dilúvio Stream in order to evaluate the impact of urbanization on sediment pollution by heavy metals.

\section{MATERIALS AND METHODS}

\subsection{Study area}

Porto Alegre has a humid subtropical climate ("Cfa" in Köppen-Geiger classification). The annual climate means are $19^{\circ} \mathrm{C}$ for air temperature, $76 \%$ for air humidity and $1,324 \mathrm{~mm}$ of precipitation (Menegat et al., 2006). The sub-basin of Dilúvio Stream has $83.74 \mathrm{~km}^{2}$, flowing through $17.6 \mathrm{~km}$, with approximately $10.5 \mathrm{~km}$ channeled (Menegat et al., 2006; Mog et al., 2014), and sinuosity of 1.08, indicating the presence of a more-linear channel. Due to periodic floods that were displacing the citizens and curtailing development in the affected regions, it was decided between the mid-1930's and 1980's (Mog et al., 2014) that the stream would be transposed and channeled. However, even in 1913, some modification had taken place in the study's area, transposing it to the current place and filling the old bed flow (Ferlini, 1913).

Although it was transposed between 1912 and 1913, this non-channeled section located approximately 4 meters from the Dilúvio's source, is the closest to pristine characteristics. In this area, there is still the presence of ciliary forest and vegetation in the surroundings, almost as a forest reserve. Near the sources of Dilúvio Stream, there are modifications such as dams and irregular occupations, which cause pollution with the release of untreated sewage and wastes directly into the stream. Downstream of the channeled area there are a high number of buildings, waterproof areas, and high population density.

The study section is embraced by a riparian forest with almost $300 \mathrm{~m}$ on the right margin (Santana Hill) and $30 \mathrm{~m}$ on the left margin (Agricultural Science College - UFRGS) many roots and branches can be found across the river bed that may cause obstruction of the local water flux and form punctual deposition sites. This section has a riparian forest according to current Brazilian environmental legislation (Brasil, 2012). Thus, the study section is possibly only slightly impacted by its surroundings and retains many aspects of the natural conditions of Dilúvio Stream.

The section between the sources and the Agronomy neighborhood (Porto Alegre City) are marked by irregular occupations. The lack of sanitation and the sewage discharges directly into the water bodies cause the traces of pollution that can be noticed before even entering the channeled area (Mog et al., 2014).

\subsection{Sediment sampling}

Composite samples of surface sediment were collected (in May 2016) with a scoop-shaped sampler (crafted with PVC pipes) in the layer from $0-5 \mathrm{~cm}$. Three subsamples were collected per site, being mixed to form the composite sample, and making laboratory triplicates of the sample for analysis. The samples were collected at an underwater depth of approximately 0.51.0 meters in the seven sites (Figure 1) of Dilúvio Stream in the portion located in the area of the Agronomy College of Universidade Federal do Rio Grande do Sul (UFRGS), Porto Alegre. 


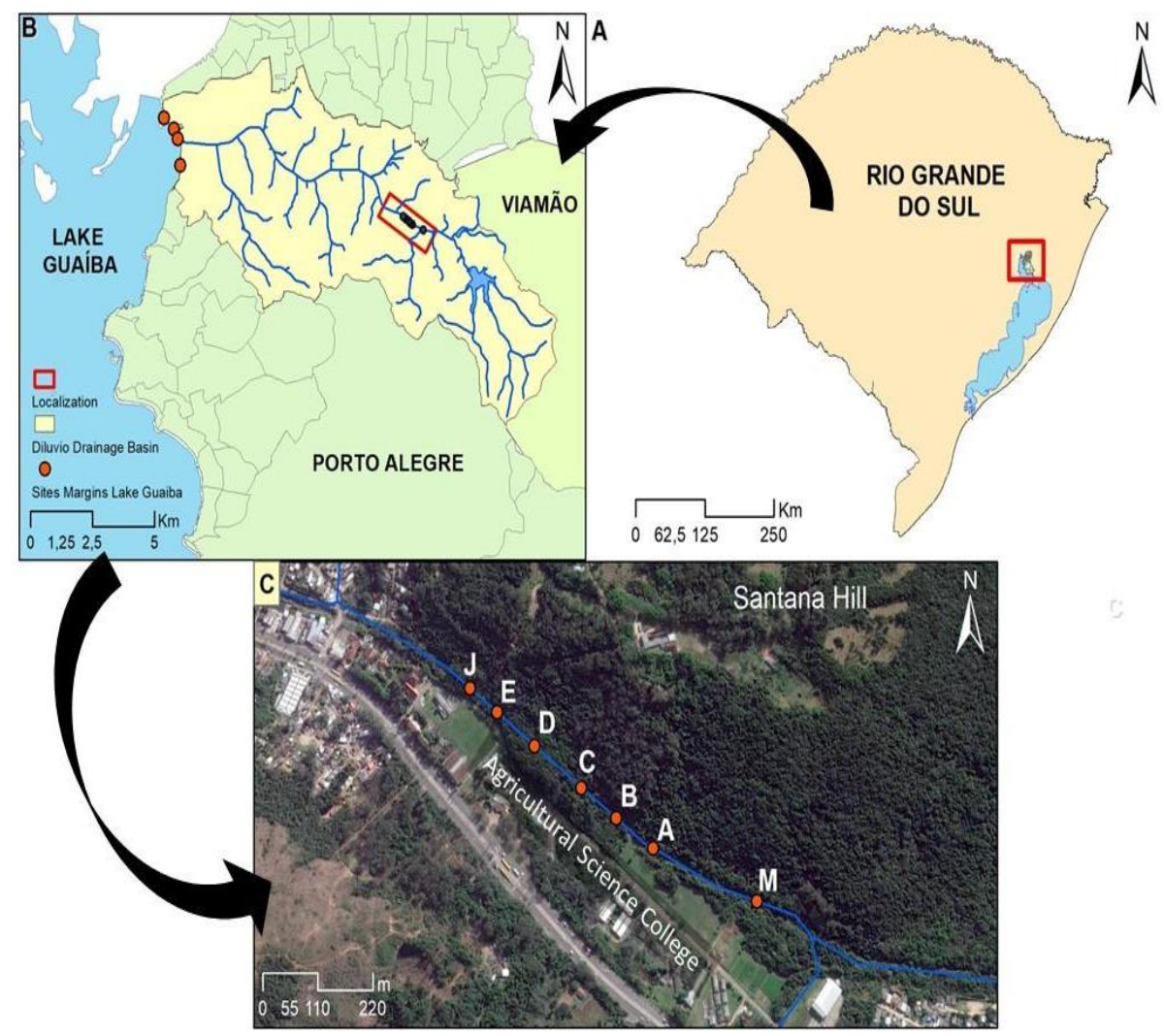

Figure 1. Location of the sites in a non-channelized section of the Dilúvio Stream.

\subsection{Sample preparation}

The samples were immediately taken to the laboratory, oven dried $\left(50^{\circ} \mathrm{C}\right)$ and sieved (2 mm) according to CONAMA Resolution No. 454 (Conama, 2012) which provides the methodology and reference values for sediment studies in Brazil. Samples in natural condition were maintained under refrigeration as counterproofs.

\subsection{Physico-chemical analysis}

The following analyses were evalueted: $\mathrm{pH}$ in $\mathrm{CaCl}_{2}$ (ratio 1:2.5; v/v), bulk density (Ds) and particle size (pipette; $70 \mathrm{~g}$ per repetition); electrical conductivity (EC; sediment/deionized water in proportion 1:5); total organic carbon (TOC; Walkley-Black; 3.5 g per repetition), assimilable phosphorus (P; Melich-1; $3.0 \mathrm{~mL}$ of sediment per repetition); Total Kjeldahl Nitrogen (TKN; 0.5 g per repetition); and pseudo-total elements, by acid digestion using 1 gram per sample according to EPA-3050B (USEPA, 1996) - Iron (Fe), Aluminum (Al), Calcium (Ca), Magnesium (Mg), Sodium (Na), Potassium (K), Manganese ( $\mathrm{Mn}$ ), Barium (Ba), Zinc (Zn), Vanadium (V), Arsenic (As), Lead (Pb), Cooper (Cu), Chrome(Cr), Cobalt (Co), Nickel (Ni), Cadmium (Cd), Molybdenum (Mo), and Selenium (Se).

All analyzes were performed in triplicates. The concentration of elements in the extracts (EPA-3050B analysis) was analyzed by Inductively Coupled Plasma Optical Emission Spectrometer (ICP-OES; PerkinElmer ${ }^{\circledR}$ Optima $^{\mathrm{TM}}$ 8300) using internal standards for control and verification of procedures (with a recovery between 81 and $105 \%$ to $\mathrm{Zn}, \mathrm{Pb}, \mathrm{Cu}, \mathrm{Cr}$ and $\mathrm{Ni}$ and Limits of Detection (LD) of: $\mathrm{Zn}-2.0 ; \mathrm{Pb}-2.0 ; \mathrm{Cu}-0.6 ; \mathrm{Cr}-0.4 ; \mathrm{Ni}-0.4 ; \mathrm{Cd}-0.2 \mathrm{ug} / \mathrm{g}$.). The X-ray diffractograms (XRD) were made into powder (Bruker ${ }^{\circledR} \mathrm{D} 2$-phaser), with $\mathrm{CuK} \alpha$ radiation $[\lambda=1.54 \AA]$, pitch $=0.020^{\circ}$ and amplitude from 4 to $70^{\circ} 2 \theta$. Halite $(\mathrm{H})$ was used as an internal marker at $0.282 \mathrm{~nm}$ to characterize the samples. Identification of minerals was performed according to Brindley and Brown (1980). 


\subsection{Statistical analysis}

The results were submitted to analysis of variance (ANOVA) and, when significant, means were compared by the Tukey test, at a 95\% confidence level $(p<0.05)$. All graphs and statistical analyzes were performed using the software Statistica ${ }^{\circledR} v 13$.

Moreover, the comparison of metal concentrations between the evaluated section of the Dilúvio Stream (AD) and two "before" (Ga) and two "after" (Gd) sites closest to the outflow (De Andrade et al., 2018) was performed by comparing the data with box-plot and submitting to statistical analysis of Kruskal-Wallis at 5\% significance in completely randomized analyses with different numbers of repetitions.

\subsection{Standardization}

Standardization by $\mathrm{Al}$ was performed by dividing the concentrations of metal by the $\mathrm{Al}$ concentration in each sample, then analyzing the coefficient of variation of the sites. The $\mathrm{Al}$ was chosen because it is one of the most common metals in the earth's crust and easily found in high concentrations in soils and sediments. This standardization compensates the different particle sizes, due to the major metal concentrations in small particle sizes.

\section{RESULTS AND DISCUSSION}

\subsection{Variation of physico-chemical properties of sediments in short distances in the non channeled section of Dilúvio Stream}

The surface sediments of the non-channeled section Dilúvio Stream showed high variation in some metals (from $31 \%$ to $199 \%$ ). However, after Al standardization, the physico-chemical variability greatly decreases from 7 to $31 \%$ between the evaluated sites (Table 1). The particle size was predominantly ( $>50 \%)$ composed of coarse sand $(0$ to $2 \varphi)$ with substantial proportions of gravel, except at site $\mathrm{D}$ where the lowest values for this variable were observed and the large accumulation of finer fractions (Table 1).

Smaller particles have a higher tendency to resuspension and move to longer distances in the stream (Sangster et al., 2015). Site D is probably a deposition site, because it is located after a curve, favoring the deposition of finer particles.

However, the high clay and silt variation coefficients disappear when these two granulometric fractions are summed up (Table 1) and low levels of these compounds may have influenced the high coefficient of variation, occurring in a similar fashion as the fine sand. In contrast, the gravel content presents more pronounced variations in its pattern, despite having a coefficient of variation below the other variables.

For pseudo total metals, there was no difference between the evaluated sites. However, Mn and $\mathrm{Ba}$ tended to present larger values upstream and $\mathrm{V}$ downstream. Most of the pseudo total metals present high (>50\%) coefficients of variation (relative to all sites) and some cases like Mn (151\%) and Ba (199\%), which differ from the other metals (Table 1).

The coefficient of variation $(<30 \%)$ decreased when compared by Al standardization. Thus, particle size variations and/or total organic carbon (TOC) increased the levels at some sites. These physico-chemical changes affect the variability of the metal contents when not analyzed by a standardization of Al. Therefore, it could be inferred that there is low variability in the physical-chemistry of Dilúvio Stream sediments at short distances in the non-channeled section. 
Table 1. Particle size (\%), bulk density (Ds), electrical conductivity (EC), $\mathrm{pH}\left(\mathrm{CaCl}_{2}\right)$, and Total Organic Carbon (TOC) and pseudo total levels of calcium, magnesium, manganese, sodium, vanadium, barium, and cobalt in the sediments of Dilúvio Stream in the study's area.

\begin{tabular}{|c|c|c|c|c|c|c|c|c|c|c|c|}
\hline Site & & $\mathbf{M}$ & $\mathbf{A}$ & B & C & D & $\mathbf{E}$ & $\mathbf{J}$ & CV\% & m \pm s.e. & CV\%/Al \\
\hline Gravel & $\%$ & $31 \mathrm{bc}^{*}$ & $42.8^{\mathrm{a}}$ & $43.9^{\mathrm{a}}$ & $23.3^{c}$ & $7.8^{d}$ & $32.9^{b}$ & $36.4^{\mathrm{ab}}$ & 39 & $31.2 \pm 2.7$ & - \\
\hline Coarse sand & $\%$ & $655^{b c}$ & $54.1^{\mathrm{d}}$ & $55.0^{\mathrm{d}}$ & $73.2^{b}$ & $85.9^{\mathrm{a}}$ & $65.8^{\mathrm{bc}}$ & $62.0^{\mathrm{cd}}$ & 16 & $65.9 \pm 2.3$ & - \\
\hline Fine sand & $\%$ & $2.8^{\mathrm{bc}}$ & $2.6^{\mathrm{bcd}}$ & $0.5^{\mathrm{e}}$ & $3.1^{\mathrm{b}}$ & $5.2^{\mathrm{a}}$ & $0.9^{\mathrm{de}}$ & $1.2^{\mathrm{cde}}$ & 69 & $2.3 \pm 0.4$ & - \\
\hline Silt & $\%$ & $0.1^{\mathrm{c}}$ & $0.2^{\mathrm{c}}$ & $0.4^{\mathrm{ab}}$ & $0.2^{b c}$ & $0.7^{\mathrm{a}}$ & $0.2^{\mathrm{bc}}$ & $0.2^{b c}$ & 71 & $0.3 \pm 0.0$ & - \\
\hline Clay & $\%$ & $0.5^{\mathrm{a}}$ & $0.4^{\mathrm{ab}}$ & $0.1^{\mathrm{cd}}$ & $0.3^{\mathrm{bcd}}$ & $0.3^{\mathrm{abc}}$ & $0.1^{\mathrm{d}}$ & $0.2^{\mathrm{bcd}}$ & 54 & $0.3 \pm 0.0$ & - \\
\hline Clay + Silt & $\%$ & $0.6^{\mathrm{b}}$ & $0.5^{b}$ & $0.6^{\mathrm{b}}$ & $0.5^{\mathrm{b}}$ & $1.0^{\mathrm{a}}$ & $0.4^{\mathrm{b}}$ & $0.4^{\mathrm{b}}$ & 40.0 & $0.6 \pm 0.1$ & - \\
\hline Ds & $\mathrm{g} \mathrm{cm}^{-3}$ & $1.52^{\mathrm{bc}}$ & $1.53^{\mathrm{b}}$ & $1.51^{\mathrm{c}}$ & $1.56^{\mathrm{a}}$ & $1.56^{\mathrm{a}}$ & $1.53^{\mathrm{b}}$ & $1.56^{\mathrm{a}}$ & 1 & $1.5 \pm 0.0$ & - \\
\hline EC & $\mu \mathrm{S} \mathrm{cm}-1$ & $62.2^{\mathrm{ab}}$ & $63.7^{\mathrm{ab}}$ & $63.5^{\mathrm{ab}}$ & $64.3^{\mathrm{ab}}$ & $67.0^{\mathrm{a}}$ & $57.8^{\mathrm{b}}$ & $59.4^{\mathrm{b}}$ & 6 & $63 \pm 0.8$ & - \\
\hline pH & $\left(\mathrm{CaCl}_{2}\right)$ & $6.6^{\mathrm{a}}$ & $6.6^{\mathrm{a}}$ & $6.5^{\mathrm{ab}}$ & $6.4^{\mathrm{c}}$ & $6.3^{c}$ & $6.6^{\mathrm{a}}$ & $6.4^{b c}$ & 2 & $6.5 \pm 0.0$ & - \\
\hline TOC & $\mathrm{g} \mathrm{kg}^{-1}$ & $1.1^{\mathrm{a}}$ & $0.8^{\mathrm{b}}$ & $0.9^{b}$ & $0.8^{b}$ & $1.0^{\mathrm{ab}}$ & $0.1^{\mathrm{c}}$ & $0.1^{\mathrm{c}}$ & 62 & $0.7 \pm 0.1$ & - \\
\hline $\mathbf{C a}$ & $\mathrm{mg} \mathrm{kg}^{-1}$ & $248^{a}$ & $278^{a}$ & $242^{a}$ & $266^{a}$ & $293^{a}$ & $329^{a}$ & $286^{a}$ & 44 & $278.0 \pm 9.0$ & 11 \\
\hline Mg & $\mathrm{mg} \mathrm{kg}^{-1}$ & $188^{a}$ & $214^{\mathrm{a}}$ & $213^{\mathrm{a}}$ & $260^{a}$ & $322^{a}$ & $249^{a}$ & $325^{a}$ & 31 & $253.0 \pm 15.4$ & 18 \\
\hline Mn & $\mathrm{mg} \mathrm{kg}^{-1}$ & $181^{a}$ & $154^{\mathrm{ab}}$ & $108^{b c}$ & $116^{b c}$ & $96^{c}$ & $125^{a b c}$ & $144^{a b c}$ & 151 & $132.0 \pm 7.2$ & 24 \\
\hline $\mathrm{Na}$ & $\mathrm{mg} \mathrm{kg}^{-1}$ & $54^{\mathrm{a}}$ & $65^{a}$ & $69^{a}$ & $80^{a}$ & $69^{a}$ & $80^{a}$ & $73^{a}$ & 64 & $70.0 \pm 3.0$ & 16 \\
\hline $\mathbf{V}$ & $\mathrm{mg} \mathrm{kg}^{-1}$ & $7^{b}$ & $6^{b}$ & $7^{\mathrm{b}}$ & $10^{\mathrm{ab}}$ & $9^{a b}$ & $12^{\mathrm{a}}$ & $8^{b}$ & 32 & $8.3 \pm 0.5$ & 26 \\
\hline $\mathbf{B a}$ & $\mathrm{mg} \mathrm{kg}^{-1}$ & $13^{\mathrm{ab}}$ & $17^{\mathrm{a}}$ & $12^{a b}$ & $11^{\mathrm{ab}}$ & $13^{\mathrm{ab}}$ & $10^{\mathrm{b}}$ & $11^{\mathrm{ab}}$ & 199 & $12.5 \pm 0.7$ & 20 \\
\hline Co & $\mathrm{mg} \mathrm{kg}^{-1}$ & $2^{a}$ & $2^{a}$ & $2^{a}$ & $2^{\mathrm{a}}$ & $2^{\mathrm{a}}$ & $2^{\mathrm{a}}$ & $2^{\mathrm{a}}$ & 40 & $1.7 \pm 0.1$ & 11 \\
\hline Al & $\mathrm{mg} \mathrm{kg}^{-1}$ & $1846^{\mathrm{a}}$ & $1856^{a}$ & $1607^{a}$ & $1795^{\mathrm{a}}$ & $2204^{a}$ & $1823^{a}$ & $1831^{\mathrm{a}}$ & 16 & $1852.0 \pm 1.0$ & - \\
\hline Coordinates & & $\begin{array}{c}-30.07227 \\
-51.1351\end{array}$ & $\begin{array}{l}-30.07173 \\
-51.13673\end{array}$ & $\begin{array}{c}-30.07122,- \\
51.13743\end{array}$ & $\begin{array}{c}-30.07075,- \\
51.13812\end{array}$ & $\begin{array}{l}-30.06996 \\
-51.13897\end{array}$ & $\begin{array}{c}-30.06963,- \\
51.13973\end{array}$ & $\begin{array}{c}-30.0694,- \\
51.1405\end{array}$ & - & - & - \\
\hline $\begin{array}{c}\text { Distance } \\
\text { from site } M\end{array}$ & meters & 0 & 170 & 257 & 340 & 463 & 546 & 625 & - & - & - \\
\hline
\end{tabular}

* Statistical difference is referred by exponential letters. Averages followed by the same letter do not differ statistically from each other. Tukey Test was applied at the 5\% probability level. Phi $(\varphi)$ : Krumbein particle size scale. Gravel: -1 to $-2 \varphi$; coarse sand: 0 to $2 \varphi$; fine sand: 3 to $4 \varphi$; silt: 5 to $8 \varphi$; clay: $\varphi>$ 9. Densities, $\mathrm{EC}, \mathrm{pH}$, and TOC in the fraction $<2 \mathrm{~mm}$. CV\% - coefficient of variation. $\mathrm{m} \pm$ se - mean \pm standard error $\mathrm{m} \pm \mathrm{se}-\mathrm{mean} \pm \mathrm{standard}$ error; /Al metal standardized by Aluminum; As, Cd, Mo, and Se were not detected. 
The bulk density of the sediment had an spread ranging from 1.51 to $1.56 \mathrm{~g} \mathrm{~cm}^{-1}$ (Table 1) with higher values in the downstream sites $(\mathrm{C}, \mathrm{D}$, and $\mathrm{J})$ and smaller in the upstream (site $\mathrm{B}$ ). There was a high correlation of bulk density with gravel content $(r=-0.72)$. The electrical conductivity (EC) of the surface sediment ranged from 58 to $67 \mu \mathrm{S} \mathrm{cm}^{-1}$ (Table 1), showing a high correlation with TOC $(\mathrm{r}=0.81 ; p<0.05)$ and clay plus silt $(\mathrm{r}=0.82 ; p<0.05)$. The $\mathrm{pH}$ had low variation, ranging between 6.3 and 6.6 (Table 1). None of these variables had a correlation with the accumulated distance.

The TOC showed a variation around 10 times with the highest values found in the upstream points (M, A, B, C, and D) and the lowest values in sites E and J. The TOC had a high correlation with the accumulated distance $(\mathrm{r}=-0.81 ; p<0.05)$, evidencing a decrease in the contents along the watercourse, and with clay $(\mathrm{r}=0.76 ; p<0.05)$, so, places with higher clay content tend to have higher TOC due to an adsorption effect between clay and organic matter. Overall, the pseudo total metal (Table 1) concentration was low. Some metals were present at non-detectable levels (e.g. As, Cd, Mo, and Se). However, significant values of $\mathrm{V}, \mathrm{Cr}$, and $\mathrm{Fe}$ were found at site E. A high correlation with the accumulated distance was found for $\mathrm{Mg}(\mathrm{r}=0.84 ; p<0.05)$, $\mathrm{Na}(\mathrm{r}=0.76 ; p<0.05)$, and $\mathrm{Ni}(\mathrm{r}=0.91 ; p<0.05)$, although there was no difference between the evaluated sites.

X-ray diffraction (Figure 2) indicated similar mineralogical compositions among all evaluated sites. There were very low mineral intensity reflections from the micas group in the vicinity of $1.0 \mathrm{~nm}$ and kaolinite $(\mathrm{Kt})$ in most of the samples. The primary minerals quartz $(\mathrm{Qz})$ and feldspar $(\mathrm{Ft})$ predominated in all samples analyzed.

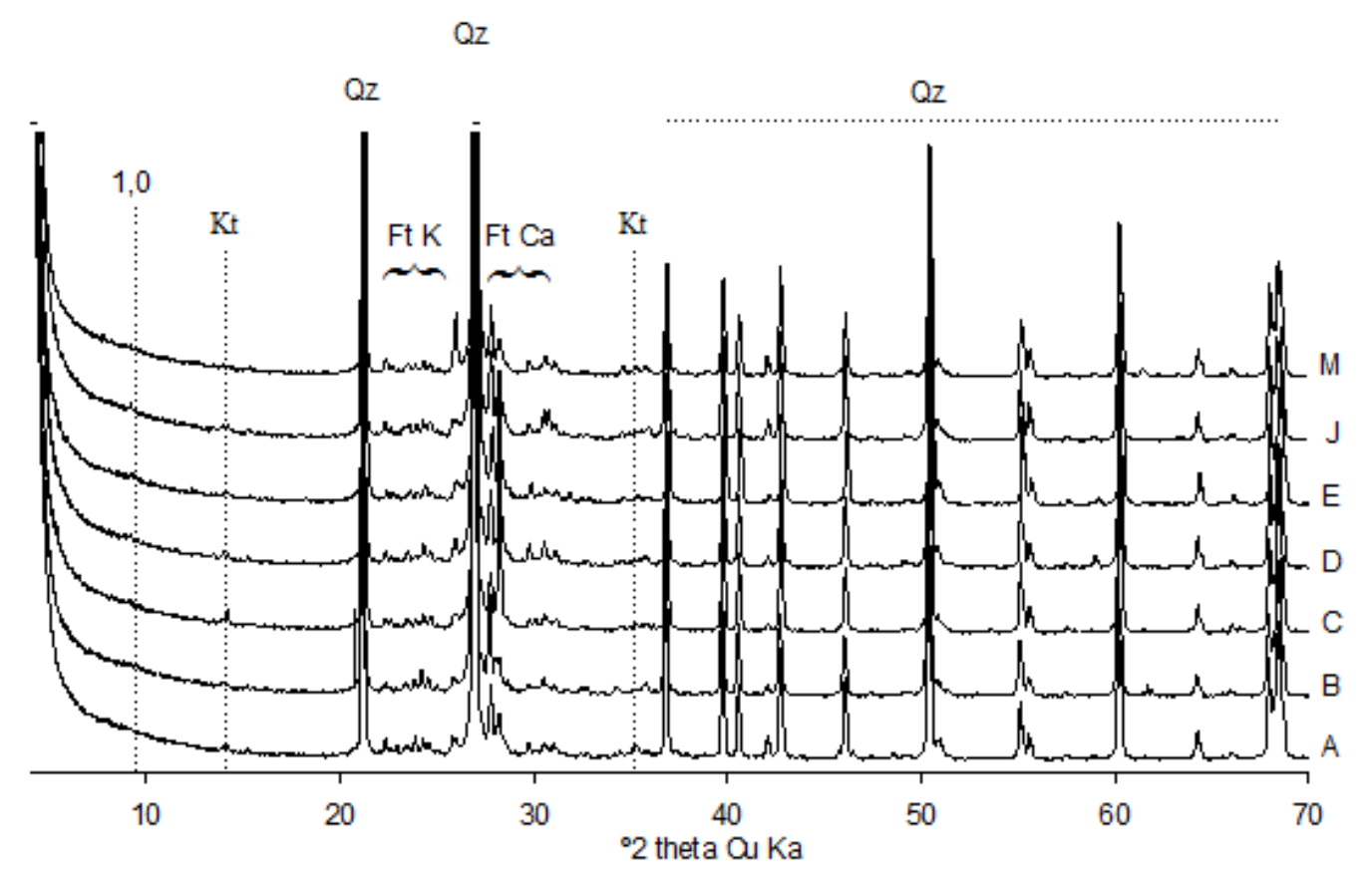

Figure 2. X-ray diffractograms (XRD) of fine sediments in the Dilúvio Stream in the study's area. Minerals 2:1, clay vermiculite and/or smectite $(1.58 \mathrm{~nm}) ;(0.10 \mathrm{~nm})$; potassium feldspar (Ft K) and calcium (Ft Ca) (0.404-0.402 $\mathrm{nm}$ and 0.321-0.299); quartz $(\mathrm{Qz})(0.334 \mathrm{~nm})$ and kaolinite $(\mathrm{Kt})$.

\subsection{Influence of the channeled section of Dilúvio Stream on sediment metal concentration}

Comparing the section of Dilúvio Stream in the study's area (AD) with the sites in the margins of Lake Guaíba, there was difference between the site upstream of the Dilúvio's outflow (Ga) in all analyzed metals, except for $\mathrm{K}$. Al and $\mathrm{K}$ had lower levels in the section upstream of the outflow (Ga) and $\mathrm{Cr}$ had lower values in the non-channeled section (Figure 3). Sites upstream $(\mathrm{Ga})$ and downstream $(\mathrm{Gd})$ shows that the non-channeled section has levels of 
metals similar to $\mathrm{Ga}$ and both were higher than $\mathrm{Gd}$. Thus, the main pollution source of this environment is located in the channeled section of Dilúvio Stream, along with the Ipiranga Avenue. However, the values of the pseudo total metals when compared to the quality reference values of CONAMA Resolution $\mathrm{N}^{\mathrm{o}} .454$ (Conama, 2012), indicate that the metal concentrations were below the reference values for Level I. Fine sediment can complex metals affecting their availability ( $\mathrm{Yu}$ et al., 2012), but CONAMA Resolution $\mathrm{N}^{\circ} .454$ (Conama, 2012) does not consider particle size as a factor for determination of guidelines values, meaning that even if the concentrations are lower than the guiding value, that does not mean that there is no pollution in the sediment.

Ipiranga Avenue has an intense traffic of vehicles, as well as a strong presence of buildings and waterproofed areas in its surroundings. These issues increase the deposition and contamination rates of road dust that flow to surface water bodies by runoff carrying metals such as $\mathrm{Zn}, \mathrm{Pb}, \mathrm{Cu}, \mathrm{Cr}$, and $\mathrm{Ni}$ (Sharley et al., 2016; Zhang et al., 2016). Nevertheless, $\mathrm{Cr}$ is also associated with atmospheric deposition near industrial areas (Sharley et al., 2016), with an historical use in leather and footwear industries in the Lake Guaíba drainage basin (De Andrade et al., 2018).

In a study evaluating the sediment sources in Dilúvio's drainage basin stream, Poleto et al. (2009) found that $46 \%$ of the suspended sediment comes on average from paved roads, $23 \%$ from unpaved roads, and $31 \%$ from the stream channel itself (channel bank). Since the majority of the sediments come from roads (paved or unpaved), it is possible to infer that the lower modification of the surroundings of the section of Dilúvio Stream in the non-channeled area could influence the minor levels of metals and TOC presented in the canal when compared to other locals like $\mathrm{Ga}$ and $\mathrm{Gd}$.

All the levels of pseudo total metals standardized by Al showed statistical differences among $\mathrm{AD}, \mathrm{Ga}$ and $\mathrm{Gd}$ sites (except $\mathrm{K}$ ). The site $\mathrm{AD}$ (non-channeled section of Dilúvio Stream) had lower levels $(p<0.05)$ when compared to sites $\mathrm{Ga}$ and $\mathrm{Gd}$ (in Lake Guaíba margins). Ga and $\mathrm{Gd}$ differed only for $\mathrm{Cr}(p<0.05)$ and $\mathrm{Ni}(p<0.1)$, with the highest values found in Ga. The environmental changes and anthropogenic influence on the surroundings of the channeled section may not appear clearly in the surface sediment standardized with Al for several reasons, such as its high sand content; the metal's enrichment by the increasing of clay plus silt and carbon; and the possibility of pollution being accumulated elsewhere downstream from Lake Guaíba. Pollution by the channeled section did not have a visible influence on heavy metal values in the sediments of $\mathrm{Gd}$ compared to $\mathrm{Ga}$ when standardized by Al (Figure 4). The difference in the proportion of fine sediments between the points may be one of the causes of the variation in concentrations between the three areas. 

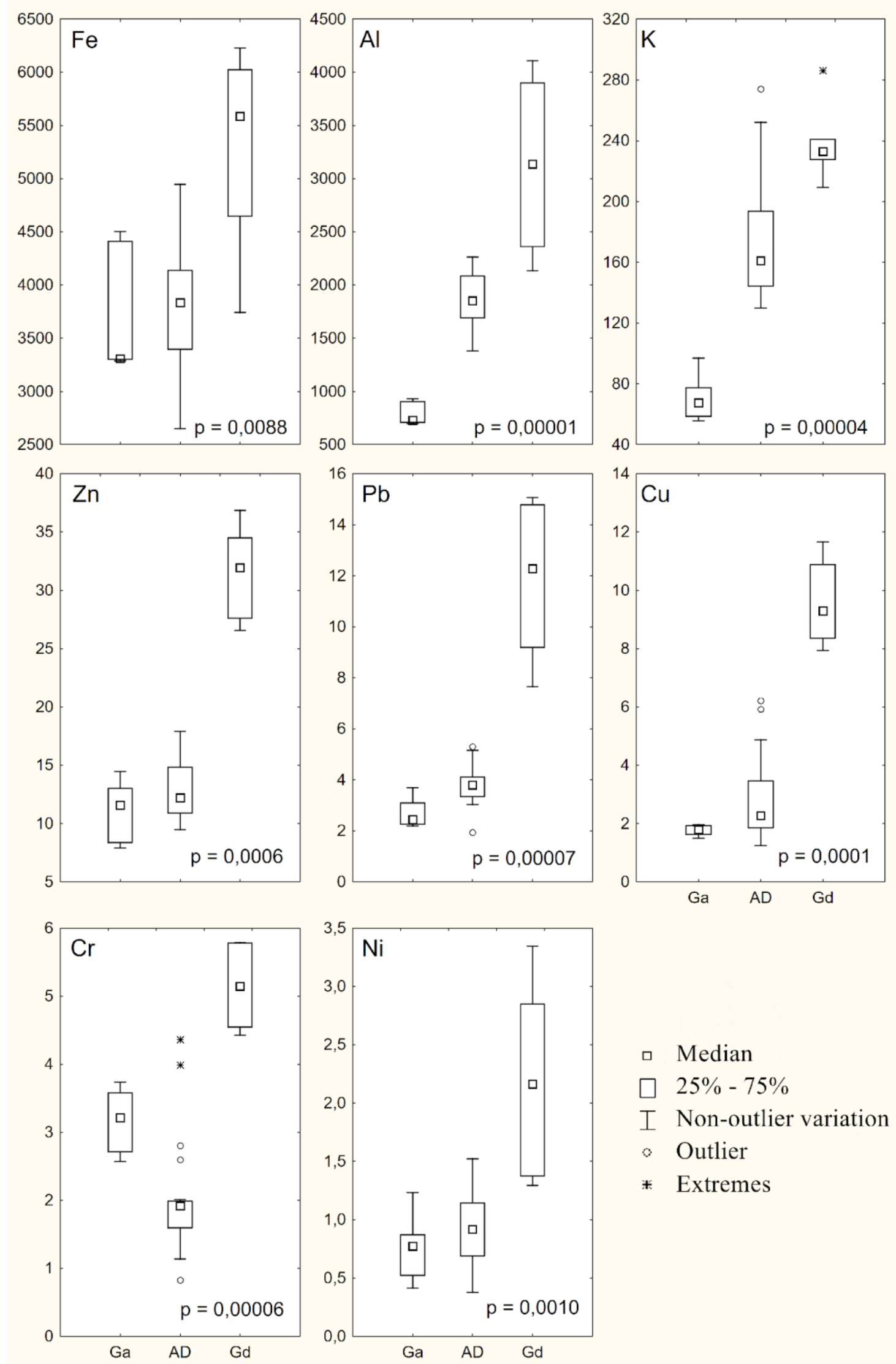

Median

$\square 25 \%-75 \%$

I Non-outlier variation

- Outlier

* Extremes

Figure 3. Pseudo Total element values $\left(\mathrm{mg} \mathrm{kg}^{-1}\right)$ in sediments of Dilúvio Stream in the study's area $(\mathrm{AD})$ and sites in Lake Guaíba margins Upstream $(\mathrm{Ga})$ and Downstream $(\mathrm{Gd})$ of the Dilúvio's outflow. Kruskal-Wallis test at 5\% probability. 

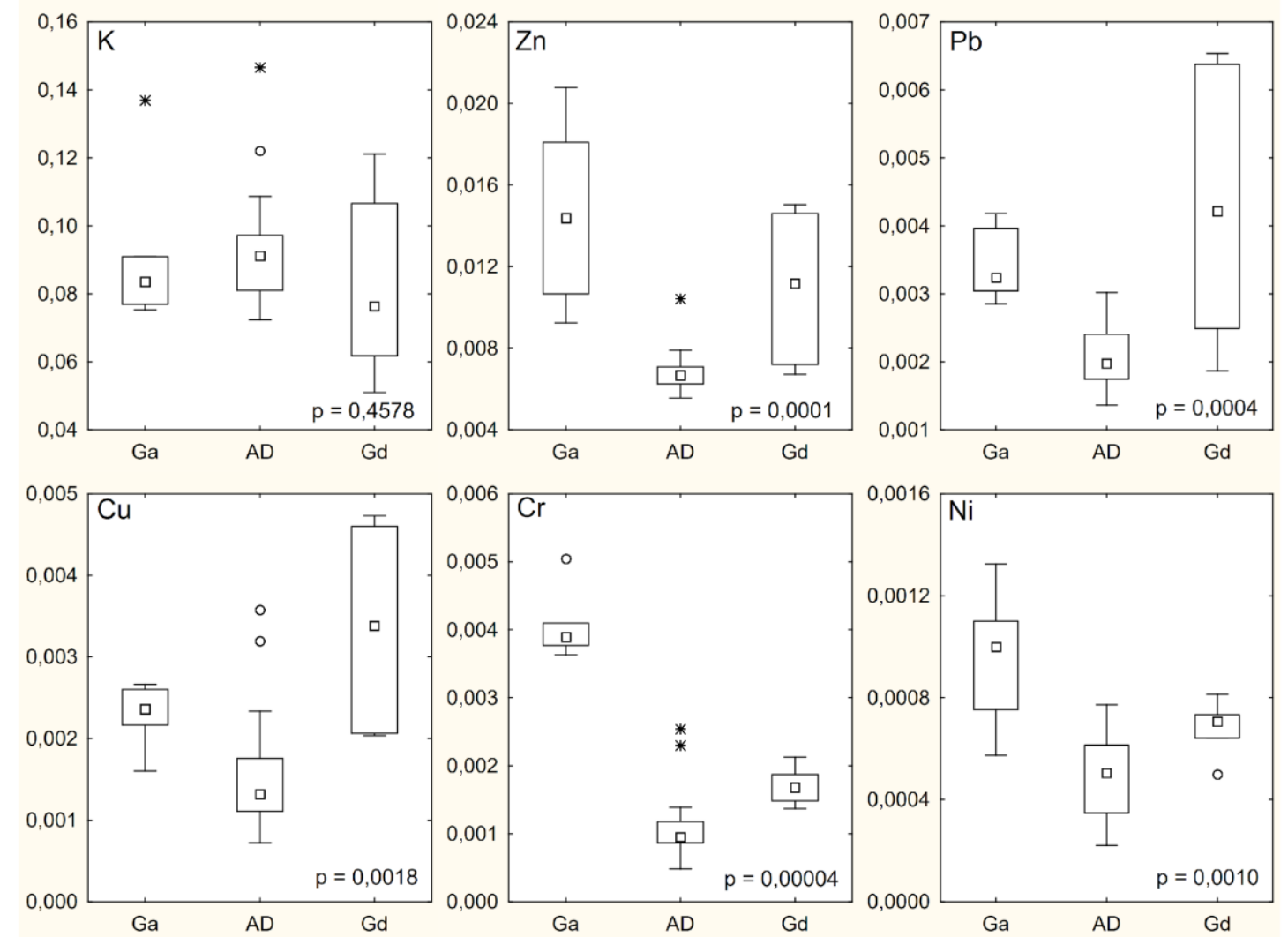

Figure 4. Pseudo Total element values $\left(\mathrm{mg} \mathrm{kg}^{-1}\right)$ standardized by $\mathrm{Al}$ in sediments of the Dilúvio Stream in the study's area (AD) and the in the sites Upstream $(\mathrm{Ga})$ and Downstream (Gd) of the Dilúvio's outflow. Kruskal-Wallis test at 5\% probability.

Soares et al. (2004) also found higher concentrations of $\mathrm{Fe}, \mathrm{Al}, \mathrm{K}, \mathrm{Zn}, \mathrm{Pb}, \mathrm{Cu}, \mathrm{Cr}, \mathrm{Ni}, \mathrm{Ca}$, $\mathrm{Mg}, \mathrm{Mn}$ and $\mathrm{Na}$ in Salso Stream (a stream from Porto Alegre City) when compared to Dilúvio Stream. The Geoaccumulation Index, based on average values and geochemical data of basement rocks of the local drainage basin, showed that the sediments presented low contamination $(\mathrm{Cr}, \mathrm{Cu}, \mathrm{Ni}, \mathrm{Pb}, \mathrm{Zn})$, although one of the indicators showed considerably high pollution with $\mathrm{Cu}, \mathrm{Ni}$ and $\mathrm{Zn}$ (Soares et al., 2004). The higher metal levels showed in the study are probably due to the higher levels of TOC found in the bed sediment (8.10-9.98\%), despite the similar sources (marginal vegetation, phytoplankton, and anthropogenic sources such as domestic effluents) and similar particle-size distribution (Upstream sites) in comparison with Dilúvio Stream. Because the metal concentrations in the AD showed lower values than in the Salso Stream, it could be expected, at least, an equal to lower anthropic influence in the section of the study of Dilúvio Stream, presenting that this section could be possibly used as a good parameter for pollution comparison with other sections of Dilúvio Stream.

Anthropogenic sources such as waste, urban sediments, traffic and domestic and industrial effluents can contribute to higher concentrations of heavy metals (Pinto et al., 2009). Nearby vegetation and phytoplankton can generate higher concentrations of organic matter that by natural reactions could maintain a higher level of heavy metals complexed in bed sediments or solubilized in water (Soares et al., 2004; Pinto et al., 2009).

Metal enrichment by fine sediment could be a factor affecting the concentration of heavy metals in the sites of Dilúvio Stream and Lake Guaíba. However, part of these sediments may come from the suspended sediment of Dilúvio Stream, having heavy metals adsorbed or not, and accumulating downstream. Azevedo et al. (2016) attribute some of the imbalance of sediment deposition in the tidal inlet of São Luís, Maranhão, Brazil to alterations, such as the 
construction of roads and the development of the nearby urban area in the river basins. The urban development in Dilúvio's drainage basin may have been misbalanced due to these alterations, as some evidence is found through the channeled area, like the accumulation of sediment and the reduction of the channel that occurs in the periodic dredging of the sediment.

Channelization results in gradual degradation impacting the biotic and abiotic components of the system, which may lead to a high and fluctuating concentration of contaminants and nutrients (Pandey et al., 2018). A previous study in Lake Guaíba (De Andrade et al., 2018) shows that the main source of punctual sediment pollution in the margins of the Lake Guaíba comes from urban streams, such as Dilúvio. Therefore, in the channeled area there is possibly an important input of pollution from anthropogenic sources in the surroundings.

The area suffers from many different and diffuse types of pollution, as it has many sources with highly varied composition, such as the traffic, building and road deterioration, untreated domestic sewage, pluvial sewage, siltation and heavy metal enrichment by fine sediment. Further studies are needed to better understand the variations and the specific sources of heavy metals in Dilúvio's drainage basin.

\section{CONCLUSIONS}

The concentration of metals in the surface sediment of the non-channeled section of the Dilúvio Stream presented a high coefficient of variation, but this variation decreased when standardization by $\mathrm{Al}$ was applied. The concentration of heavy metals in the non-channeled section of Dilúvio Stream was similar to the site in the margins of Lake Guaíba before the outflow of Dilúvio Stream and smaller than both points in the margins of Lake Guaíba when compared with the Al standardization. The Dilúvio Stream channeled area possibly suffers anthropogenic influence through diffuse pollution sources and the imbalance of sediment deposition, especially in the outflow, that may be causing metal enrichment by fine sediments.

The improvement of the environmental conditions in the Dilúvio Stream should be targeted by local government policies in order to mitigate the pollution of Dilúvio Stream and Lake Guaíba, improving the quality of life, environment and local population. To achieve this goal, the government should apply a management plan to the whole basin and focus not only on the stream itself.

\section{REFERENCES}

AZEVEDO, J. W. de J.; CASTRO, A. C. L. de; SANTOS, M. C. F. V. dos. Siltation rate and main anthropic impacts on sedimentation of the São Luís tidal inlet - State of Maranhão, Brazil. Brazilian Journal of Oceanography, v. 64, n. 1, p. 9-18, 2016. http://dx.doi.org/10.1590/S1679-87592016092106401

BRASIL. Lei No 12.651, de 25 de maio de 2012. Dispõe sobre a proteção da vegetação nativa. Diário Oficial [da] União: seção 1, Brasília, DF, 28 maio 2012.

BRINDLEY, G. W.; BROWN G. Crystal Structures of Clay Minerals and their X-ray Identification. London: Mineralogical Society of Great Britain and Ireland, 1980. v. 5, 495 p. http://dx.doi.org/10.1180/mono-5

CONSELHO NACIONAL DO MEIO AMBIENTE - CONAMA. Resolução n 454, de 01 de novembro de 2012. Diário oficial [da] União: seção 1, Brasília, DF, p. 66, 08 Nov. 2012.

De ANDRADE, L. C.; TIECHER, T.; OLIVEIRA, J. S. de; ANDREAZZA, R.; INDA, A. V.; CAMARGO, F. A. de O. Sediment pollution in margins of the Lake Guaíba, Southern Brazil. Environmental Monitoring and Assessment, v. 190, n. 1, 2018. http://dx.doi.org/10.1007/s10661-017-6365-9 
FERLINI, J. Relatório da Escola de Engenharia de Porto Alegre. Porto Alegre: Instituto de Agronomia e Veterinária, 1913. 71 p.

JARTUN, M.; OTTESEN, R. T.; STEINNES, E.; VOLDEN, T. Runoff of particle bound pollutants from urban impervious surfaces studied by analysis of sediments from stormwater traps. Science of the Total Environment, v. 396, n. 2-3, p. 147-163, 2008. http://dx.doi.org/10.1016/j.scitotenv.2008.02.002

MENEGAT, R.; PORTO, M. L.; CARRARO, C. C.; FERNANDES, L. A. D. (Eds.). Atlas Ambiental de Porto Alegre. 3. ed. Porto Alegre: Editora da Universidade/UFRGS, 2006. $256 \mathrm{p}$.

MOG, W.; ÁVILA, H.; LÍVIA, C.; PICCININI, S. Morphological analysis of urban spaces in river basins: analyzing the surroundings of Dilúvio River in Porto Alegre. Cadernos Metrópole, v. 16, n. 31, p. 221-239, 2014. http://dx.doi.org/10.1590/2236-9996.20143110

PANDEY, L. K.; LAVOIE, I.; MORIN, S.; PARK, J.; LYU, J.; CHOI, S. et al. River water quality assessment based on a multi-descriptor approach including chemistry, diatom assemblage structure, and non-taxonomical diatom metrics. Ecological Indicators, v. 84, p. 140-151, 2018. http://dx.doi.org/10.1016/j.ecolind.2017.07.043

PIGNERET, M.; MERMILLOD-BLONDIN, F.; VOLATIER, L.; ROMESTAING, C.; MAIRE, E. et al. Urban pollution of sediments: Impact on the physiology and burrowing activity of tubificid worms and consequences on biogeochemical processes. Science of The Total Environment, v. 568, p. 196-207, 2016. http://dx.doi.org/10.1016/j.scitotenv.2016.05.174

PINTO, A. G. N.; HORBE, A. M. C.; SILVA, M. do S. R. da; MIRANDA, S. A. F.; PASCOALOTO, D.; SANTOS, H. M. da C. Efeitos da ação antrópica sobre a hidrogeoquímica do rio Negro na orla de Manaus/AM. Acta Amazônica, v. 39, n. 3, p. 627-638, 2009. http://dx.doi.org/10.1590/S0044-59672009000300018

POLETO, C.; MERTEN, G. H.; MINELLA, J. P. The identification of sediment sources in a small urban watershed in southern Brazil: An application of sediment fingerprinting.

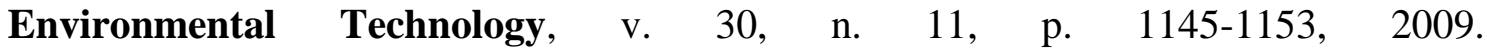
http://dx.doi.org/10.1080/09593330903112154

SANGSTER, J. L.; OKE, H.; ZHANG, Y.; BARTELT-HUNT, S. L. The effect of particle size on sorption of estrogens, androgens and progestagens in aquatic sediment. Journal of $\begin{array}{llllll}\text { Hazardous } & \text { Materials, } & \text { v. 299, } & \text { p. }\end{array}$ http://dx.doi.org/10.1016/j.jhazmat.2015.05.046

SHARLEY, D. J.; SHARP, S. M.; BOURGUES, S.; PETTIGROVE, V. J. Detecting long-term temporal trends in sediment-bound trace metals from urbanised catchments. $\begin{array}{llllll}\text { Environmental Pollution, } & \text { v. 219, p. }\end{array}$ http://dx.doi.org/10.1016/j.envpol.2016.06.072

SOARES, M. C. C.; MIZUSAKI, A. M. P.; GUERRA, T.; VIGNOL, M. L. Análise Geoquímica dos Sedimentos de Fundo do Arroio do Salso, Porto Alegre - RS - Brasil. Pesquisas em Geociências, v. 31, n. 1, p. 39-50, 2004.

UNITED STATES. Environmental Protection Agency - USEPA. Method 3050B: acid digestion of sediments, sludges, and soils. Revision 2. Washington, DC, 1996. 
YU, T.; ZHANG, Y.; ZHANG, Y. Distribution and bioavailability of heavy metals in different particle-size fractions of sediments in Taihu Lake, China. Chemical Speciation and $\begin{array}{lllllll}\text { Bioavailability, } & \text { v. } 24, \quad \text { n. } 4, & \text { p. } & 205-215,\end{array}$ http://dx.doi.org/10.3184/095422912X13488240379124

YUAN, X.; TIAN, F.; WANG, X.; LIU, Y.; CHEN, M. Small-scale sediment scouring and siltation laws in the evolution trends of fluvial facies in the Ningxia Plain Reaches of the Yellow River (NPRYR). Quaternary International, v. 476, p. 14-25, 2018. http://dx.doi.org/10.1016/j.quaint.2018.03.034

ZHANG, Z.; WANG, J. J.; ALI, A.; DELAUNE, R. D. Heavy metals and metalloid contamination in Louisiana Lake Pontchartrain Estuary along I-10 Bridge. Transportation Research Part D: Transport and Environment, v. 44, p. 66-77, 2016. http://dx.doi.org/10.1016/j.trd.2016.02.014 


Ambiente \& Água - An Interdisciplinary Journal of Applied Science
ISSN 1980-993X - doi:10.4136/1980-993X
www.ambi-agua.net
E-mail: ambi.agua@gmail.com

\title{
Losses of soil, water, organic carbon and nutrients caused by water erosion in different crops and natural savannah in the northern Amazon
}

\author{
ARTICLES doi:10.4136/ambi-agua.2126 \\ Received: 24 Apr. 2017; Accepted: 01 Nov. 2018 \\ Fernando Gomes de Souza ${ }^{1 *(D)}$; Valdinar Ferreira Melo ${ }^{2}$; \\ Wellington Farias Araújo ${ }^{2}$; Thiago Henrique de Castro Araújo ${ }^{3}$ \\ ${ }^{1}$ Instituto Federal de Educação, Ciência e Tecnologia de Rondônia (IFRO), Colorado do Oeste, RO, Brasil \\ E-mail: fernando.souza@ifro.edu.br \\ ${ }^{2}$ Universidade Federal de Roraima (UFRR), Boa Vista, RR, Brasil \\ Departamento de Solos e Engenharia Agrícola (DSEA). E-mail: valdinar@yahoo.com.br, \\ wellington.araujo@ufrr.br \\ ${ }^{3}$ Universidade Federal de Roraima (UFRR), Boa Vista, RR, Brasil \\ Centro de Ciências Agrárias. E-mail: thiagohenriaraujo@gmail.com \\ "Corresponding author
}

\begin{abstract}
Currently in Brazil, the main form of erosion is caused by the impact of raindrops on the soil surface, triggering the process of water erosion and causing serious damage to agricultural areas. This study evaluated losses of soil, water, organic carbon and nutrients in different cultures, bare soil and savanna under natural rain. The experimental design was completely randomized with five treatments (bare soil - BS, cowpea bean - $\mathrm{CB}$, Brachiaria brizantha - BB, corn - $\mathrm{CO}$ and natural savanna - SN) with three replications; The treatment of bare soil (BS), followed by the treatment cultivated with cowpea bean (CB) showed higher losses of soil, water, organic carbon and nutrients; The highest losses of soil, water, organic carbon and nutrients in the treatment of bare soil (BS) occurred during the period of greatest erosivity; but for treatments $\mathrm{CB}, \mathrm{BB}$ and $\mathrm{CO}$, the highest losses occurred during the establishment of the crop, in view of the lower soil cover. Soils cultivated with Brachiaria brizantha - BB, corn - CO and in the Natural Savana - SN area were more efficient in reducing soil and water losses during all months evaluated. Plant cover produced by the $(\mathrm{SN})$ treatment and by the $(\mathrm{BB})$ and $(\mathrm{CO})$ treatments acted to reduce the harmful effects of erosion, minimizing losses of nutrients and organic carbon. The soil should be well protected during periods when rainfall presents the highest values of erosivity index.
\end{abstract}

Keywords: losses due to erosion, Roraima, soil degradation, soil management.

\section{Perdas de solo, água, carbono orgânico e nutrientes por erosão hídrica em diferentes cultivos e savana natural no norte da Amazônia}

\section{RESUMO}

Atualmente no Brasil a principal forma de erosão é causada pelo impacto das gotas de chuva na superfície do solo, desencadeando o processo de erosão hídrica e causando sérios danos às áreas agrícolas. Este trabalho foi realizado com o objetivo de avaliar perdas de solo, 
água, nutrientes e carbono orgânico em diferentes culturas, solo descoberto e savana, sob chuva natural. $\mathrm{O}$ delineamento experimental foi inteiramente casualizado com cinco tratamentos (solo descoberto - SD, feijão-caupi - FC, Braquiária brizantha - BB, milho - MI e savana natural $\mathrm{SN}$ ) com três repetições; O tratamento do solo descoberto (SD), seguido do tratamento com feijão-caupi (FC) apresentou maiores perdas de solo, água, nutrientes e carbono orgânico; As maiores perdas de solo, água, nutrientes e carbono orgânico no tratamento do solo descoberto (SD) ocorreram durante o período de maior erosividade, mas para os tratamentos FC, BB e MI ocorreram durante o estabelecimento da cultura, tendo em vista a menor cobertura do solo; Solos cultivados com Brachiaria brizantha - BB, Milho - MI e a área com Savana Natural $\mathrm{SN}$, foram mais eficientes na redução das perdas de solo e água, durante todos os meses avaliados. A Cobertura vegetal proporcionada pelo tratamento $(\mathrm{SN})$ e pelos tratamentos $(\mathrm{BB})$ e (MI) atuaram na redução dos efeitos danosos da erosão, minimizando as perdas de nutrientes e carbono orgânico; O solo deve estar bem protegido durante os períodos em que a chuva apresente os maiores valores do índice de erosividade.

Palavras-chave: degradação do solo, manejo do solo, perdas por erosão, Roraima.

\section{INTRODUCTION}

Water erosion is a physical phenomenon that includes the phases of soil disintegration, transport and deposition, promoted by the action of natural agents such as impact of rainfall and surface runoff (Dechen et al., 2015). It is the main degradation process of agricultural soils by anthropic interference. Water erosion is influenced by the characteristics and distribution of rainfall, soil type, topography, soil cover and management, and by conservationist practices supporting agricultural production (Bertol et al., 2007; Panagos et al., 2015).

Soil erosion is a complex phenomenon, involving the infiltration of water into the soil, the storage of part of the precipitated water and runoff. According to Silva et al. (2005b) and Telles et al. (2013), erosion has contributed to the impoverishment and reduction of the sustainability of agroecosystems by causing the loss of soil, water, nutrients and organic carbon. Besides causing the degradation of agricultural areas, water erosion results in economic, social and environmental damages that can be minimized with the adoption of soil conservation practices important in the control of erosion (Rabelo and Griebeler, 2012).

The best way to avoid damage caused by erosion is by the maintenance or recovery of the physical, chemical and biological conditions of the soil, and by establishing criteria for land use and management, in order not to compromise the land's productive capacity, aiming to increase the availability of water, nutrients and the soil's biological activity, creating adequate growing conditions for plants (Cunha et al., 2017). Soil cover provided by natural vegetation, crops or by the remains of cultures is fundamental to reducing soil, water and nutrient losses due to water erosion (Pires et al., 2006; Panachuki et al., 2011; Volk and Cogo; 2014). Soil cover also acts to reduce the impact force of rainfall, soil disruption, surface sealing and flood velocity, so any change in vegetation cover will directly affect the runoff rate (Zhou et al., 2002; Silva et al., 2005a; Leite et al., 2009; Pugliesi et al., 2011; Cardoso et al., 2012).

In Roraima state, the soil's diversity is a reflection of climatic factors and biotic and landscape characteristics, marked by a reduction of precipitation that occurs in the central area of the State (Melo et al., 2010). Some soils here show cohesion characteristics with severe laminar erosion (Benedetti et al., 2011), features found mainly in the savan nah area, which are areas formed by extensive planed surfaces covered by shrub, grassy-woody and herbaceous vegetation (Feitosa et al., 2016).

Assessing water erosion in the cultivation of Acacia mangium in the savanna area of the State of Roraima, Barros et al. (2009) observed that during the period evaluated, denser acacia 
vegetal cover was the main factor in reducing water erosion. Barbosa and Fearnside (2000), analyzing soil erosion by rainwater in two land uses (primary forest and forest-derived pasture) between August and February 1992 in the region of Apiaú, Roraima, observed that the rate of erosion in pastures $\left(1,128 \mathrm{~kg} \mathrm{ha}^{-1}\right.$ year $\left.^{-1}\right)$, was 7.5 times higher than in the adjacent forest $\left(150 \mathrm{~kg} \mathrm{ha}^{-1}\right.$ year $\left.^{-1}\right)$. This causes the successive degradation of soil fertility and suggests that pastures derived from forests in the Amazon are unsustainable land-use systems for the region. This work evaluated soil, water, nutrient and organic carbon losses in Brachiaria brizantha, cowpea bean (Vigna unguiculata), corn (Zea mays), bare soil and natural savanna.

\section{MATERIALS AND METHODS}

\subsection{Localization and Characterization of the study area}

The experiment was conducted at the experimental unit of the Center of Agricultural Sciences (CCA), the Cauamé Campus of the Federal University of Roraima (UFRR), Boa Vista - RR, geographical reference coordinates $2^{\circ} 52^{\prime} 16^{\prime \prime} \mathrm{N}$ and $60^{\circ} 42^{\prime} 47^{\prime \prime} \mathrm{W}$.

The soil of the experimental unit was classified as a Dystrophic Yellow Latosol (Xantic Hapludox, Soil Taxanomy) (Embrapa, 2013), soil with low natural fertility, originated from pre-weathered clayey-sandy sediments of the Boa Vista formation (Benedetti et al., 2011), positioned in flat relief at a mean altitude of $80 \mathrm{~m}$ (Table 1).

Table 1. Soil chemical analysis of the experimental area at Campus do Cauamé at UFRR.

\begin{tabular}{|c|c|c|c|c|c|c|c|c|c|c|c|c|c|}
\hline \multirow{3}{*}{ Depth } & \multirow{3}{*}{$\mathrm{pH}$} & \multicolumn{8}{|c|}{ Sortive Complex } & \multirow{2}{*}{$\mathrm{V}$} & \multirow{2}{*}{$\mathrm{m}$} & \multirow{2}{*}{$\mathrm{P}$} & \multirow{2}{*}{$\mathrm{C}$} \\
\hline & & $\mathrm{Ca}^{2+}$ & $\mathrm{Mg}^{2+}$ & $\mathrm{K}^{+}$ & $\mathrm{Al}^{3+}$ & $\mathrm{H}^{+}+\mathrm{Al}^{3+}$ & S & $\mathrm{CECe}$ & $\mathrm{CECt}$ & & & & \\
\hline & & \multicolumn{8}{|c|}{$\mathrm{cmol}_{\mathrm{c}} \mathrm{dm}^{-3}$} & \multicolumn{2}{|c|}{$\%$} & $\mathrm{mg} \mathrm{dm}^{-3}$ & $\mathrm{~g} \mathrm{dm}^{-3}$ \\
\hline $0-15$ & 5.18 & 081 & 0.25 & 0.02 & 1.60 & 2.26 & 1.08 & 2.68 & 3.34 & 32.34 & 59.70 & 5.05 & 10.01 \\
\hline $15-30$ & 4.21 & 3.38 & 0.10 & 0.01 & 2.40 & 3.65 & 3.49 & 5.89 & 7.14 & 48.88 & 40.75 & 3.89 & 6.19 \\
\hline
\end{tabular}

pH: in water; S: sum of bases; CECe: Effective CEC; CECt: total CEC; V: base saturation; m: Al saturation; P: available phosphorus, and C: organic carbon.

The dystrophic yellow latosols that occupy $22 \%$ of the Roraima state are soils of low natural fertility, with physical problems when dry (they are hard or cohesive), obstructing root development, and have low values of exchangeable cations, with $\mathrm{Al}^{+3}$ dominating the exchange complex, as well as low levels of organic matter and available phosphorus (P) (Melo et al., 2010). The cultivation of grains in the state of Roraima is being developed in these soils, with a great increase of soybean and corn. The climatic characterization of the region according to the Köppen classification is type AW, tropical rainy, hot and humid, with annual average rainfall of $1.600 \mathrm{~mm}$, with dry period from October to March (Araújo et al., 2001).

\subsection{Measuring precipitation}

Rainfall precipitation was recorded daily, through the automatic meteorological station installed approximately $200 \mathrm{~m}$ from the experimental area. The experiment considered rainfall events separately if an event was separated by at least $6 \mathrm{~h}$ from another event, with maximum rain of $1.0 \mathrm{~mm}$. Rains were considered erosive if they were equal to or greater than $10.0 \mathrm{~mm}$, or equal to or greater than $6.0 \mathrm{~mm}$ in a period of less than 15 minutes, according to the criteria proposed by Wischmeier and Smith (1978), with modifications suggested by Carvalho et al. (1989). The duration of the rains was measured periodically at intervals of 24 hours, and was obtained using a rain gauge installed in the automatic station, considering the contact time from the beginning to the end of the precipitation (in hours or minutes). 
The monthly erosion rate and average rainfall was expressed by the $\mathrm{EI}_{30}$ index (Wischmeier and Smith, 1958) in the International System of Units - MJ mm ha ${ }^{-1} \mathrm{~h}^{-1}$ (Foster et al., 1981), obtained by the product of the total kinetic energy of rainfall (E - MJ ha-1) and the maximum intensity in 30 minutes $\left(\mathrm{I}_{30}-\mathrm{mm} \mathrm{h}^{-1}\right)$, according to Wischmeier and Smith (1958), and grouped by months. The kinetic energy of the rains was determined by Equation 1 of Wischmeier and Smith (1958), adjusted to the International System of Units by Foster et al. (1981).

$$
E c=0.119+0.0873 \log I p
$$

Where EC - is the kinetic energy, $\mathrm{MJ} \mathrm{ha}^{-1} \mathrm{~mm}^{-1}$ and Ip is the precipitation intensity $\left(\mathrm{mm} \mathrm{h}^{-1}\right)$.

The total kinetic energy of the individual erosive rain was obtained by the sum of the kinetic energy of each segment of the rain, while the maximum intensity in thirty minutes was obtained according to Equation 2, proposed by Carvalho et al. (1989):

$I_{30}=\frac{\left(\sum_{i=1}^{n} i_{n i} x t_{n i}\right)}{30}$

Where: $\mathrm{I}_{30}$ - is the rain intensity in 30 consecutive minutes $\left(\mathrm{mm} \mathrm{h}^{-1}\right)$; In - is the value for rain intensity of order $\mathrm{n}\left(\mathrm{mm} \mathrm{h}^{-1}\right)$, occurring within 30 minutes; Tn - is the period of occurrence of rain intensity of order $n$, occurring within 30 minutes.

After obtaining the maximum intensity within thirty minutes, the values were applied in Equation 3 to calculate the erosivity index $\left(\mathrm{EI}_{30}\right)$ of each precipitation. In turn, the monthly $\mathrm{EI}_{30}$ was obtained by the sum of the $\mathrm{EI}_{30}$ of each erosive precipitation that occurred in that month.

$E I_{30}=E C_{t} \times I_{30}$

Where: $\mathrm{EI}_{30}$ - is the erosion index of individual erosive rain, $\mathrm{MJ} \mathrm{mm} \mathrm{ha}^{-1} \mathrm{~h}^{-1}$ and $\mathrm{I}_{30}$ - is the maximum rainfall intensity in the period of 30 consecutive minutes, $\mathrm{mm} \mathrm{h}^{-1}$.

\subsection{Facilities of the experimental area}

The experimental design chosen was completely structured with five treatments (bare soil - BS, cowpea bean planting - CB, Brachiaria brizantha - BB, corn planting - CO and savanna - SN) and three replicates per treatment with collections over time. This experiment was carried out on a slope of $2 \%$ in blocks, positioned at the center of the experimental area, with dimensions of $2.0 \times 18.0 \mathrm{~m}\left(36 \mathrm{~m}^{2}\right)$ and spacing of $1.0 \mathrm{~m}$. The courts were flanked with galvanized zinc leaves $0.30 \mathrm{~m}$ high, imbedded $0.10 \mathrm{~m}$ in the ground to block the entrance and exit of the eroded material. At the lower ends of each block, $0.30 \mathrm{~m}$ wide galvanized steel plates were drilled into the ground, leaving $0.20 \mathrm{~m}$ above the surface.

PVC collector pipes $(100 \emptyset \mathrm{mm})$ were installed, coupled to the collecting tube and interconnected to two storage tanks with $200 \mathrm{~L}$ capacity each, whose function was the accumulation of water and sediments (Figure 1). The first interconnected tank served for water storage. At the end of each pipe exiting the block geo bags were placed to retain the sediments and release water and fine sediments (silt and clay). At the exit end of the first tank, a $25 \mathrm{~mm}$ PVC pipe connected it to the second tank with 10 sections of equal-flow outlets. Only one was used for collection in the second tank and the other was discarded, since it's function was simply to avoid overflow in the case of high precipitation. In the second tank, the water values obtained were multiplied by 10 for the final calculation of the losses that occurred, which added with the values of the first tank. 


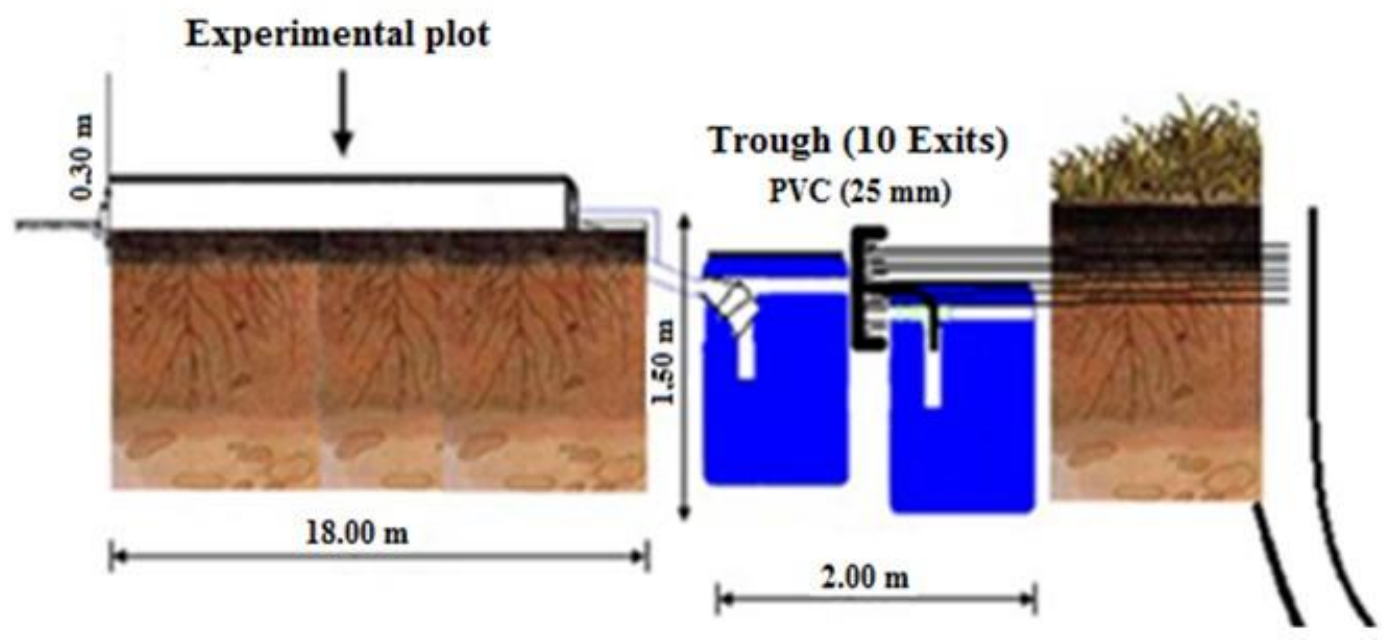

Figure 1. Representation of the experimental area with PVC collecting pipes, coupled to the collecting trough and interconnected to $200 \mathrm{~L}$ tanks.

The frequency of collection of soil for the quantification of losses of soil, water, organic carbon and nutrients ranged from one to two per day, depending on the occurence of each rain considered to have erosive potential. Rainfall characteristics were analyzed based on the records obtained each day at the automatic meteorological station installed near the experimental area, taking into account rainfall intensity and the kinetic energy of raindrops on the soil. This made it possible to calculate the erosive potential of each rain, expressed by the EI30 value (Bertoni and Lombardi Neto 2012).

After installing the collector blocks, conventional soil preparation was carried out with manual soil rotation by hoe and hoeing in all experimental plots, in addition to the plantings in the experimental area with the following treatments: 1- Brachiaria brizantha (BB); 2 - corn cultivation (CO); 3 - cowpea bean (CB); 4 - bare soil (BS) and 5 - natural savanna (SN).

The cultivated plots were fertilized according to the recommendations for each crop. For corn and brachiaria, fertilizer was applied in the proportion of $110 \mathrm{~kg} \mathrm{ha}^{-1}$ of $\mathrm{N}$, divided into two applications: the first 15 days after emergence, in the amount of $50 \mathrm{~kg} \mathrm{ha}^{-1}$ of $\mathrm{N}$; the second 35 days after emergence, with $60 \mathrm{~kg} \mathrm{ha}^{-1}$, in addition to $120 \mathrm{~kg} \mathrm{ha}^{-1}$ of $\mathrm{P}_{2} \mathrm{O}_{5}$ and $60 \mathrm{~kg} \mathrm{ha}^{-1}$ of $\mathrm{K}_{2} \mathrm{O}$ at planting. For cowpea, $80 \mathrm{~kg} \mathrm{ha}^{-1}$ of $\mathrm{P}_{2} \mathrm{O}_{5}$ and $60 \mathrm{~kg} \mathrm{ha}^{-1}$ of $\mathrm{K}_{2} \mathrm{O}$ were added to the soil, and the seeds were inoculated with strain BR 3267. At 90 days before planting, all experimental plots and treatments (BS and $\mathrm{SN}$ ) were corrected with dolomitic limestone according to liming recommendation for experimental area, equivalent to $2000 \mathrm{~kg} \mathrm{ha}^{-1}$. The fertilizers were applied to the soil, aiming to standardize the application in the planting area.

\subsection{Determination of soil and water losses}

Soil losses were determined by the direct method during the crop cycle, during the months of higher precipitation in the year of 2013, based on rainfall data from previous years.

Surface runoff, along with the sediments transported from the experimental plots, occurred through PVC pipes $(100 \mathrm{~mm})$ to a collection structure positioned at the lower-slope end of the experimental area. In this structure, the transported sediments were retained in the previously weighed filter (geotextile blanket), which allowed the collection of the coarsest soil particles transported (Silva et al., 2005a).

Considering that the blanket did not retain all the diameters of suspended soil particles in the runoff, at each data collection the volume of water in the storage drum was homogenized and an aliquot was taken to determine the amount of suspended soil that had passed by the filter. In this way the suspended material collected in a $500 \mathrm{ml}$ glass beaker were placed to dry in a forced circulation oven at $105^{\circ} \mathrm{C}$ until the water was totally evaporated. The acquired mass was 
later added to the mass of soil retained in the filter to total the loss of soil. The height of the water column drained to the collection tanks was measured using a one-meter long millimeter ruler placed in the center of each tank. The water volume of the tank was determined according to the height of the water slide and the diameter of each tank.

\subsection{Determination of nutrient and organic carbon losses}

Nutrient losses were determined during the rainy season with the highest precipitation in 2013, based on rainfall data from previous years. For each determination of the soil losses in the plots, soil samples were taken for quantification of organic $\mathrm{P}, \mathrm{K}, \mathrm{Ca}, \mathrm{Mg}$ and $\mathrm{C}$ (C-org) in the sediments. Thus, the amounts transported per area of each element were obtained through the chemical analyses of the dry sediments of each plot and the suspended material.

The total exchangeable contents of cations $\left(\mathrm{Ca}^{2+} \mathrm{e} \mathrm{Mg}^{2+}\right)$ were extracted in $\mathrm{KCl} 1 \mathrm{~mol} \mathrm{~L}^{-1}$ and titrated with EDTA (Embrapa, 2011). Phosphorus (P) and potassium (K) were extracted by Mehlich $^{-1}\left(\mathrm{H}_{2} \mathrm{SO}_{4} 0.0125 \mathrm{~mol} \mathrm{~L}^{-1}+\mathrm{HCl} 0.05 \mathrm{~mol} \mathrm{L^{-1 }}\right), \mathrm{P}$ being visible by UV spectrophotometry and $\mathrm{K}^{+}$by flame photometry (Embrapa 2011). C-org was determined by the modified Walkley and Black method (Yeomans and Bremner, 1988), based on the oxidation of organic matter by dichromate of potassium, with diphenylamine being used as an indicator (Embrapa, 2011).

\subsection{Statistical analysis}

The results obtained from losses of soil, water, nutrients and organic carbon in each replicate were submitted to analysis of variance (ANOVA), through the statistical program SISVAR (Ferreira, 2008), and were compared to the Tukey test at the 5\% probability level $(\mathrm{p}<0.05)$.

\section{RESULTS AND DISCUSSION}

\subsection{Loss of soil and water by surface runoff}

During the evaluation in June, the highest losses occurred in the treatment of bare soil (BS), with $302.61 \mathrm{~kg} \mathrm{ha}^{-1}$ month $^{-1}$ (Table 2). This was because BS did not present any type of cover, which allows the detachment and transport of soil after particle spattering caused by the impact of raindrops; these results are in agreement with those obtained by Bertol et al. (2007), Barros et al. (2009) and Panachuki et al. (2011). Another factor observed was the treatment of cowpea bean (CB) with $149.01 \mathrm{~kg} \mathrm{ha}^{-1}$ month $^{-1}$, which showed significant differences when compared to other treatments, a fact that may be related to the specific behavior of types of ground cover, or even spacing in relation to the structure of the plant during its initial vegetative cycle, thus providing greater soil losses in relation to the treatments of BB with $12.74 \mathrm{~kg} \mathrm{ha}^{-1}$ month $^{-1}$, CO with $81.52 \mathrm{~kg} \mathrm{ha}^{-1}$ month $^{-1}$ and SN with $8.07 \mathrm{~kg} \mathrm{ha}^{-1}$ month $^{-1}$ (Table 2). According to Cardoso et al. (2012), the groundcover plants' strains influence these losses; therefore, it is expected that a species with a high coverage index and biomass productivity will provide higher protection to the soil, reducing the impact of the raindrops on it as well as the surface runoff. Castro et al. (2011) and Cardoso et al. (2013) state that the crop coverage index is directly related to the development of plant and that should protect the soil from the beginning of the crop cycle. They recommend reduced spacing when the objective is rapid coverage of soil and phytomass production. In this way, the erosion rates can be reduced by increasing the ground cover. The presence of vegetation helps water retention in the soil and reduces the speed of the runoff (Lima et al., 2013), since the cover is a major factor on the dissipation of the kinetic energy of the raindrops (Guth, 2010). 
Table 2. Soil losses $\left(\mathrm{kg} \mathrm{ha}^{-1}\right)$ for treatments using bare soil (BS), plantation of cowpea bean (CB), planting with Brachiaria brizantha (BB), corn (CO) and savanna).

\begin{tabular}{|c|c|c|c|c|c|}
\hline & June & July & August & & \\
\hline Treatment & \multicolumn{3}{|c|}{ Soil Losses $\left(\mathrm{kg} \mathrm{ha}^{-1}\right.$ month $\left.^{-1}\right)$} & Total & Average \\
\hline BS & $302.61 \mathrm{a}$ & $301.92 \mathrm{a}$ & $460.74 \mathrm{a}$ & $1,065.27$ & 355.09 \\
\hline $\mathrm{CB}$ & $149.01 \mathrm{~b}$ & $99.80 \mathrm{~b}$ & $59.55 \mathrm{~b}$ & 308.36 & 102.79 \\
\hline BB & $12.74 \mathrm{c}$ & $0.00 \mathrm{c}$ & $0.00 \mathrm{~b}$ & 12.74 & 4.25 \\
\hline $\mathrm{CO}$ & $81.52 \mathrm{bc}$ & $5.83 \mathrm{c}$ & $44.91 \mathrm{~b}$ & 132.26 & 44.09 \\
\hline $\mathrm{SN}$ & $8.07 \mathrm{c}$ & $3.30 \mathrm{c}$ & $11.00 \mathrm{~b}$ & 22.37 & 7.46 \\
\hline $\mathrm{CV}(\%)$ & 28.34 & 139.55 & 72.57 & & \\
\hline Precipitation of erosive rainfall $(\mathrm{mm})$ & 86.8 & 107.4 & 177.8 & 372 & 124 \\
\hline $\mathrm{EI}_{30}\left(\mathrm{MJ} \mathrm{mm}^{-1} \mathrm{ha}^{-1} \mathrm{~h}^{-1}\right)$ & 976.63 & 1476.62 & 2305.65 & 4758.90 & 1586.30 \\
\hline Kinetic Energy $\left(\mathrm{MJ} \mathrm{mm}{ }^{-1}\right.$ month $\left.^{-1}\right)$ & 0.63076 & 0.94562 & 1.22993 & 2.80630 & 0.93543 \\
\hline
\end{tabular}

The values followed by the same letter in the columns do not differ according to the Tukey test at $0.05 \%$ probability.

When soil losses were evaluated during July, it was observed that the treatments BS, CB, $\mathrm{BB}, \mathrm{CO}$ and $\mathrm{SN}$ followed the same statistical trend of the previous month, but with lower losses. This may be related to the occurrence of low intensity rains, in addition to a scenario of better crop development presented during the month of July. Santos et al. (2010), evaluating the intense rains related to water erosion, found that the aspects that interfere the most with soil erosion are intensity, duration, frequency and erosivity. As other works highlight, rainfall erosivity is considered one of the most important factors to estimate soil losses (Shamshad et al., 2008).

During the evaluation in August, it was observed that the highest soil losses occurred in the treatment of BS with $460.74 \mathrm{~kg} \mathrm{ha}^{-1}$ month $^{-1}$, while the other treatments $\mathrm{CB}, \mathrm{BB}, \mathrm{CO}$ and SN did not show significant differences ( 0.05 scored on Tukey test). The high value of soil losses for the BS treatment is related to heavy rainfalls during the period and to the high degree of superficial surface sealing due to the absence of groundcover plants within the respective treatments. The results are in agreement with the studies of Bertol et al. (2007), which demonstrate that conventional preparation of less-protected soils provides a greater rate of decrease of infiltration reflex of superficial ground sealing. In this same context, other studies confirm the results obtained, where they affirm that after several months of rainfall, the soil is more saturated and the water infiltration rate decreases, with increased surface runoff, and high losses of soil and water (Carvalho et al., 2012; Oliveira et al., 2013).

The BB, SN and CO treatments have been shown to better protect the soil when compared to the $\mathrm{BS}$ and $\mathrm{CB}$ treatments, as they promoted greater soil coverage due to the greater green biomass and enhanced root development. In this regard, the results observed corroborate the studies of Soane et al. (2012) and Lima et al. (2013), which found that erosion rates can be reduced with the increase of groundcover plants, since the presence of vegetation aids the retention of water and reduces the speed of surface runoff. Cover is fundamental to the dissipation of the kinetic energy of raindrops (Guth, 2010).

The erosivity index data $\left(\mathrm{EI}_{30}\right)$ of evaluated months (Table 2$)$ was obtained by method proposed by Wischmeier and Smith (1958), which is recognized world-wide as the R factor of USLE, and recommended for use in several regions worldwide, including in Brazil (North: Barros et al., 2009; South: Bertol et al., 2007; Cogo et al., 2003; Guadagnin et al., 2005; Marioti et al., 2013; Oliveira et al., 2015; Southeast: Cardoso et al., 2012; Dias et al., 2013; Pires et al., 2006; Silva et al., 2005a Midlewest: Leite et al., 2009; Panachuki et al., 2011; and Northeast: Albuquerque et al., 1998). 
Regarding the total of water losses that occurred during the month of June, it was observed that the studied BS, CB and BB treatments did not differ statistically among themselves, using the Tukey test at a 0.05 probability. Irregular distribution and low rainfall can explain the low values of water losses (Table 3).

During July, due to the increased rainfall regime, it was possible to diagnose higher water losses in the treatment of BS, with $253.92 \mathrm{~m}^{3} \mathrm{ha}^{-1} \mathrm{month}^{-1}$ (Table 3), statistically superior to the other treatments under study. Similar results were obtained by Panachuki et al. (2011) and Marioti et al. (2013). It was also observed that the CB treatment of $134.47 \mathrm{~m}^{3} \mathrm{ha}^{-1} \mathrm{month}^{-1}$ presented higher water losses when compared to treatments of $\mathrm{BB}, \mathrm{CO}$, and $\mathrm{SN}$ (Table 3).

Table 3. Water losses $\left(\mathrm{m}^{3} \mathrm{ha}^{-1}\right)$ for treatments, bare soil (BS), cowpea (CB), Brachiaria brizantha (BB), corn (CO) and savanna (SN).

\begin{tabular}{lccccc}
\hline \multicolumn{1}{c}{ June } & July & August & & \\
\hline Treatment & Water losses $\left(\mathrm{m}^{3} \mathrm{ha}^{-1}\right.$ & month $\left.^{-1}\right)$ & Total & Average \\
\hline BS & $69.32 \mathrm{a}$ & $253.92 \mathrm{a}$ & $599.43 \mathrm{a}$ & 922.67 & 307.56 \\
$\mathrm{CB}$ & $57.89 \mathrm{a}$ & $134.47 \mathrm{~b}$ & $284.70 \mathrm{~b}$ & 477.06 & 159.02 \\
$\mathrm{BB}$ & $47.47 \mathrm{ab}$ & $0.39 \mathrm{~d}$ & $0.00 \mathrm{~d}$ & 47.86 & 15.95 \\
$\mathrm{CO}$ & $15.52 \mathrm{c}$ & $20.65 \mathrm{~d}$ & $88.86 \mathrm{~cd}$ & 125.03 & 41.68 \\
$\mathrm{SN}$ & $24.44 \mathrm{bc}$ & $49.70 \mathrm{c}$ & $217.79 \mathrm{bc}$ & 291.93 & 97.31 \\
$\mathrm{CV}(\%)$ & 21.60 & 9.10 & 22.10 & & \\
\hline Precipitation of erosive rainfall $(\mathrm{mm})$ & 86.8 & 107.4 & 177.8 & 372 & 124 \\
EI $_{30}\left(\mathrm{MJ} \mathrm{mm}\right.$ ma $\left.^{-1} \mathrm{~h}^{-1}\right)$ & 976.63 & 1476.62 & 2305.65 & 4758.90 & 1586.30 \\
Kinetic Energy $\left(\mathrm{MJ} \mathrm{mm}^{-1}\right.$ month $\left.^{-1}\right)$ & 0.63076 & 0.94562 & 1.22993 & 2.80630 & 0.93543 \\
\hline
\end{tabular}

The values followed by the same letter in the columns do not differ according to the Tukey test at $0.05 \%$ probability.

In the month of August, the BS treatment of $599.43 \mathrm{~m}^{3} \mathrm{ha}^{-1}$ month $^{-1}$ presented higher water losses, followed by CB treatments of $284.70 \mathrm{~m}^{3} \mathrm{ha}^{-1}$ month $^{-1}$ and $\mathrm{SN}$ of $217.79 \mathrm{~m}^{3} \mathrm{ha}^{-1} \mathrm{month}^{-1}$. The other treatments under study followed the same trend of July, where the $\mathrm{BB}$ and $\mathrm{CO}$ treatments did not present significant differences (Table 3).

By establishing a comparative analysis between soil and water losses within all treatments during the three-month evaluation period and based on the total precipitation of collected erosive rains, it was possible to verify that the $\mathrm{BB}, \mathrm{CO}$ and $\mathrm{SN}$ treatments were more effective in reducing soil and water losses in all evaluated months (Table 2 and 3). For the BB treatment, this fact is attributed to the root system of the grasses being of the fasciculated type, acting as an important restructuring agent of the raindrops, according to the results obtained by Cardoso et al. (2012). The occurrence of lower sediment losses in the BB and CO treatments can be explained by the fact that both crops present more protectionist features due to the greater ground coverage and faster development that delays the beginning of the surface runoff. These results are in accordance with those obtained by Marioti et al. (2013). For the SN treatment, the flow was softened due to the presence of existing natural vegetation, something that directly contributed to the protection against the impact of rain drops. In this condition the soil presented a greater infiltration capacity and has a lower runoff rate. Similar results were found by Barros et al. (2009) working in Oxisol and Ultisol of Roraima savanna. According to Cabanêz et al. (2011), surface runoff only begins when the soil exceeds its water infiltration capacity and is directly related to the intensity of the precipitation.

After data analysis of the precipitation of erosive rains, with soil $\left(\mathrm{kg} \mathrm{ha}^{-1}\right)$ and water losses $\left(\mathrm{m}^{3} \mathrm{ha}^{-1}\right)$, it was observed that the losses remained high in the BS treatment, while the other treatments showed some variations; e.g., the BB treatment reduced groundcover (Table 2 and 
3). It was observed that the precipitation which occurred during the month of August generated a larger flood volume, promoting significant soil drag in all treatments except for the BB treatment, where the flood was attenuated by the vegetation coverage.

\subsection{Loss of nutrient and organic carbon in sediments by flash flood}

After the evaluations carried out in June, it was observed that for the $\mathrm{Ca}^{2+}$ nutrient the greatest losses occurred in HR treatment with $0.206 \mathrm{~kg} \mathrm{ha}^{-1}$, differing statistically from the other treatments (Table 4). The lowest losses of these nutrients occurred in the BB treatment, with $0.013 \mathrm{~kg} \mathrm{ha}^{-1}$ and SN with $0.004 \mathrm{~kg} \mathrm{ha}^{-1}$, probably due to the presence of foliar cover to minimize nutrient losses in the sediments of the flood, which was also observed by other authors like Barros et al. (2009), Ekholm and Lehtoranta (2012) and Sousa et al. (2012), where nutrient losses can occur associated with transport by the flow or adsorbed by the sediments carried on the flood.

Table 4. Nutrient loss and organic carbon $\left(\mathrm{kg} \mathrm{ha}^{-1}\right)$ values for treatments, bare soil (BS), cowpea bean $(\mathrm{CB})$, Brachiaria brizantha $(\mathrm{BB})$, corn $(\mathrm{CO})$ and savanna $(\mathrm{SN})$.

\begin{tabular}{|c|c|c|c|c|c|c|c|}
\hline \multirow{3}{*}{ Treatment } & \multirow{3}{*}{$\begin{array}{c}\mathbf{E I}_{\mathbf{3 0}} \\
\left(\mathbf{M J} \mathbf{~ m m}^{-\mathbf{1}} \mathbf{h a}^{-\mathbf{1}} \mathbf{h}^{-\mathbf{1}}\right) \\
976.63\end{array}$} & \multirow{2}{*}{\multicolumn{2}{|c|}{$\begin{array}{l}\text { Kinetic energy } \\
\text { (MJ mm-1 month) }\end{array}$}} & \multicolumn{4}{|c|}{$\begin{array}{c}\text { Loss of nutrient and organic carbon in } \\
\text { sediments by flash flood }\end{array}$} \\
\hline & & & & \multicolumn{4}{|c|}{ June (kg ha $\left.{ }^{-1}\right)$} \\
\hline & & 0.63076 & $\mathrm{Ca}^{2+}$ & $\mathrm{Mg}^{2+}$ & $\mathrm{P}$ & $\mathrm{K}^{+}$ & $\mathrm{CO}$ \\
\hline BS & & & $0.103 b$ & $0.270 \mathrm{a}$ & $0.018 \mathrm{c}$ & $0.003 \mathrm{ab}$ & $1.678 \mathrm{a}$ \\
\hline CB & & & $0,206 \mathrm{a}$ & $0.161 \mathrm{~b}$ & $0.248 \mathrm{a}$ & $0.004 \mathrm{a}$ & $0.626 \mathrm{~b}$ \\
\hline BB & & & $0.013 \mathrm{c}$ & $0.010 \mathrm{~d}$ & $0.092 \mathrm{~b}$ & $0.000 \mathrm{c}$ & $0.082 \mathrm{~b}$ \\
\hline $\mathrm{CO}$ & & & $0.114 b$ & $0.092 \mathrm{c}$ & $0.051 \mathrm{bc}$ & $0.001 \mathrm{bc}$ & $0.463 \mathrm{~b}$ \\
\hline $\mathbf{S N}$ & & & $0.004 \mathrm{c}$ & $0.003 \mathrm{~d}$ & $0.002 \mathrm{c}$ & $0.000 \mathrm{c}$ & $0.034 \mathrm{~b}$ \\
\hline Average & & & 0.088 & 0.107 & 0.107 & 0.0016 & 0.577 \\
\hline CV $(\%)$ & & & 25.80 & 17.86 & 28.90 & 36.51 & 37.39 \\
\hline Treatment & $\begin{array}{c}\text { EI30 } \\
\left(\mathbf{M J} \mathbf{m m}^{-1} \mathbf{h a}^{-1} \mathbf{h}^{-1}\right)\end{array}$ & \multicolumn{2}{|c|}{$\begin{array}{l}\text { Kinetic energy } \\
\text { (MJ } \mathbf{~ m m}^{-1} \text { month) }\end{array}$} & \multicolumn{4}{|c|}{ July (kg ha' $\left.{ }^{-1}\right)$} \\
\hline & 1.476 .62 & 0.94562 & $\mathrm{Ca}^{2+}$ & $\mathrm{Mg}^{2+}$ & $\mathrm{P}$ & $\mathrm{K}^{+}$ & $\mathrm{CO}$ \\
\hline BS & & & $0.098 \mathrm{a}$ & $0.076 \mathrm{ab}$ & $0.013 \mathrm{~b}$ & $0.002 \mathrm{ab}$ & $0.860 \mathrm{a}$ \\
\hline CB & & & $0.154 \mathrm{a}$ & $0.116 \mathrm{a}$ & $0.185 \mathrm{a}$ & $0.006 \mathrm{a}$ & $0.566 \mathrm{~b}$ \\
\hline BB & & & $0.000 \mathrm{~b}$ & $0.000 \mathrm{c}$ & $0.000 \mathrm{c}$ & $0.000 \mathrm{c}$ & $0.000 \mathrm{c}$ \\
\hline $\mathrm{CO}$ & & & $0.005 \mathrm{~b}$ & $0.006 \mathrm{bc}$ & $0.006 \mathrm{bc}$ & $0.0004 \mathrm{c}$ & $0.028 \mathrm{c}$ \\
\hline $\mathbf{S N}$ & & & $0.003 \mathrm{~b}$ & $0.003 \mathrm{c}$ & $0.003 \mathrm{c}$ & $0.0001 \mathrm{c}$ & $0.012 \mathrm{c}$ \\
\hline Average & & & 0.052 & 0.040 & 0.065 & 0.0017 & 0.293 \\
\hline CV (\%) & & & 62.00 & 63.04 & 7.18 & 69.15 & 30.34 \\
\hline Treatment & 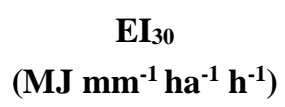 & \multicolumn{2}{|c|}{$\begin{array}{c}\text { Kinetic energy } \\
\text { (MJ mm } \text { month }^{-1} \text { mont }\end{array}$} & \multicolumn{4}{|c|}{ August (kg ha-1) } \\
\hline & 2.305 .65 & 1.22993 & $\mathrm{Ca}^{2+}$ & $\mathrm{Mg}^{2+}$ & $\mathrm{P}$ & $\mathrm{K}^{+}$ & $\mathrm{CO}$ \\
\hline BS & & & $0.143 \mathrm{a}$ & $0.155 \mathrm{a}$ & $0.049 \mathrm{ab}$ & $0.003 \mathrm{a}$ & $1.875 \mathrm{a}$ \\
\hline CB & & & $0.085 \mathrm{ab}$ & $0.068 \mathrm{~b}$ & $0.171 \mathrm{a}$ & $0.004 \mathrm{a}$ & $0.225 \mathrm{~b}$ \\
\hline BB & & & $0.000 \mathrm{c}$ & $0.000 \mathrm{~b}$ & $0.000 \mathrm{c}$ & $0.000 \mathrm{~b}$ & $0.000 \mathrm{~b}$ \\
\hline $\mathrm{CO}$ & & & $0.025 \mathrm{bc}$ & $0.030 \mathrm{~b}$ & $0.035 \mathrm{ab}$ & $0.0014 \mathrm{ab}$ & $0.090 \mathrm{~b}$ \\
\hline $\mathbf{S N}$ & & & $0.007 \mathrm{c}$ & $0.006 \mathrm{~b}$ & $0.006 \mathrm{c}$ & $0.005 \mathrm{ab}$ & $0.068 \mathrm{~b}$ \\
\hline Average & & & 0.052 & 0.052 & 0.052 & 0.0027 & 0.452 \\
\hline $\mathrm{CV}(\%)$ & & & 45.99 & 57.99 & 108.80 & 66.90 & 24.17 \\
\hline
\end{tabular}

Values followed by the same letter in the columns do not differ significantly from each other, according to the Tukey test at $0.05 \%$ probability.

When $\mathrm{Mg}^{2+}$ losses were evaluated, the highest losses were observed in the treatment of BS with $0.270 \mathrm{~kg} \mathrm{ha}^{-1}$ followed by the treatment of $\mathrm{CB}$ with $0.161 \mathrm{~kg} \mathrm{ha}^{-1}$; similar results were 
obtained by (Dias et al., 2013). For the CB treatment, the growth of the plant during its vegetative cycle might have influenced the losses of nutrients in this system, considering studies evaluating cover plants in the control of water erosion done by Dias et al. (2013), which affirm that the speed at which a given plant covers the soil surface greatly influences the erosion process. This is due to the initial period of crop growth, when the soil surface is unprotected and more susceptible to erosion. In the same sense, Cardoso et al. (2012) state that the more intertwined the aerial part of the plants, the lower are the losses due to erosion.

The lower losses of $\mathrm{Mg}^{2+}$ followed the same trend of the $\mathrm{Ca}^{2+}$ nutrient, since the BB with $0.010 \mathrm{~kg} \mathrm{ha}^{-1}$ and SN with $0.003 \mathrm{~kg} \mathrm{ha}^{-1}$ treatments were the ones with the lowest losses of this nutrient. For the nutrient $\mathrm{P}$, the highest losses occurred in the treatment of $\mathrm{CB}$ with $0.248 \mathrm{~kg} \mathrm{ha}^{-1}$, followed by the BB treatment with $0.092 \mathrm{~kg} \mathrm{ha}^{-1}$ and $\mathrm{CO}$ with $0.051 \mathrm{~kg} \mathrm{ha}^{-1}$ (Table 4). $\mathrm{P}$ losses in the treatments follow the sequence of $\mathrm{CB}>\mathrm{BB}>\mathrm{CO}>\mathrm{SN}>\mathrm{BS}$. In regards to phosphorus loss, it can be said that it is mainly associated with small particles of the mineral fraction (clay) and organic matter, which are preferably transported by the surface runoff. The highest losses of $\mathrm{K}^{+}$were observed within the treatments with $0.004 \mathrm{~kg} \mathrm{ha}^{-1}$ and BS with $0.003 \mathrm{~kg} \mathrm{ha}^{-1}$. Studies have shown that $\mathrm{K}^{+}$, due to its lower retention by soil constituents, facilitates transport by water from the runoff, corroborating works by Silva et al. (2005a). Aguiar et al. (2006) found similar results and stated that, in general, high loss of $\mathrm{K}^{+}$may occur due to its high solubility, which facilitates transport by water. As with phosphorus, the loss of soil potassium by water erosion is more associated with sediment (Cogo et al., 2003).

After analyzing the organic carbon losses in June, it was observed that the losses were higher in the BS treatment, with $1.678 \mathrm{~kg} \mathrm{ha}^{-1}$; the other treatments $\mathrm{CB}, \mathrm{BB}, \mathrm{CO}$ and $\mathrm{SN}$ did not present significant differences (Table 4). The high organic carbon losses in BS is justified by studies demonstrating that colloidal fraction and organic matter are the first components to be removed by water erosion, due to its low density (Silva et al., 2005a).

When the $\mathrm{Ca}^{2+}$ losses were evaluated in the month of July, it was possible to observe that the highest losses occurred in the $\mathrm{CB}$ treatments, with $0.154 \mathrm{~kg} \mathrm{ha}^{-1}$, and $\mathrm{BS}$, with $0.098 \mathrm{~kg} \mathrm{ha}^{-1}$. Both treatments did not present significant differences. CO and SN did not present significant differences between them by the Tukey test at the 0.05 probability level. $\mathrm{Mg}^{2+}$ losses in the month of July followed the $\mathrm{Ca}^{2+}$ trend, with the highest losses occurring in the CB treatments, with $0.116 \mathrm{~kg} \mathrm{ha}^{-1}$, and BS, with $0.076 \mathrm{~kg} \mathrm{ha}^{-1}$. According to Cogo et al. (2003) and Sousa et al. (2012), soil calcium and magnesium are removed by the same process during water erosion, mainly adsorbed to its solid particles. Both $\mathrm{Ca}^{2+}$ and $\mathrm{Mg}^{2+}$ are easily leachable (Silva et al., 2005b; Cardoso et al., 2012). In view of the probable exposure to $\mathrm{Ca}^{2+}$ and $\mathrm{Mg}^{2+}$ losses, it is associated with the high soil losses that occurred in the treatments of BS and $\mathrm{CB}$ during the months evaluated.

For P losses, it was possible to observe that the results followed the same trend of the evaluations carried out in June, where it presented higher losses for the treatment of CB with $0.185 \mathrm{~kg} \mathrm{ha}^{-1}$; thus, the high content of this nutrient may be related to its natural selectivity, because $\mathrm{P}$ is associated mainly with smaller particles of the mineral fraction (clay) and organic matter, which are preferably transported by the surface runoff. For the nutrient $\mathrm{K}^{+}$, it was observed that the highest losses occurred in the $\mathrm{CB}$ treatment with $0.006 \mathrm{~kg} \mathrm{ha}^{-1}$ and BS with $0.002 \mathrm{~kg} \mathrm{ha}^{-1}$, but the treatments in $\mathrm{BB}, \mathrm{CO}$ and $\mathrm{SN}$ did not present significant differences between them. These results concerning the losses of $\mathrm{P}$ and $\mathrm{K}^{+}$, which occurred in July, can be justified based on other studies, which indicate that the application of fertilizers in crops over a long period of time tends to increase the concentration of P and K (Schick et al., 2000). This generates increase in the concentrations of these nutrients in both the water and the sediments present in flooding (Guadagnin et al., 2005). Another factor that may have contributed to these losses in the CB treatment may be related to the different behavior of the foliar cover types, 
adopted spacing or even in relation to the structure of the plant during its vegetative cycle, which resulted in higher soil losses in comparison to the BB, CO and SN treatments.

When the losses of organic carbon were analyzed in July, it was observed that the highest carbon losses occurred in the BS treatment with $0.860 \mathrm{~kg} \mathrm{ha}^{-1}$, followed by the CB treatment with $0.566 \mathrm{~kg} \mathrm{ha}^{-1}$, showing the same behavior of the month of June for both treatments. However, the BB, CO and SN treatments did not present significant differences between them. For the $\mathrm{BB}$ and $\mathrm{CO}$ treatments, the results may be justifiable considering that both treatments were already established and at the end of the cycle, providing greater leaf coverage in relation to the other treatments. These results corroborate those found by Ekholm and Lehtoranta (2012). Spohr et al. (2009) and Dechen et al. (2015), which state that a higher percentage of vegetation cover, soil surface roughness and crop evapotranspiration improve soil water infiltration rates and, consequently, lower the losses by runoff. However, the SN treatment can be justified based on Albuquerque et al. (2005), which highlight that soils under native vegetation are usually in a better aggregation state and have stable organic matter content.

The evaluations carried out in August show no significant differences in $\mathrm{Ca}^{2+}$ losses between the BS treatment with $0.143 \mathrm{~kg} \mathrm{ha}^{-1}$ and the CB treatment with $0.085 \mathrm{~kg} \mathrm{ha}^{-1}$. When the $\mathrm{Mg}^{2+}$ losses were considered, it was possible to observe that the highest losses occurred in the BS treatment with $0.155 \mathrm{~kg} \mathrm{ha}^{-1}$ followed by the $\mathrm{CB}, \mathrm{BB}, \mathrm{CO}$ and $\mathrm{SN}$ treatments, so that they did not present significant differences among themselves by the Tukey test at 0.05 probability. For the nutrient $\mathrm{P}$, it was observed that $\mathrm{CB}$ treatments with $0.171 \mathrm{~kg} \mathrm{ha}^{-1}$, BS with $0.049 \mathrm{~kg} \mathrm{ha}^{-1}$ and $\mathrm{CO}$ with $0.035 \mathrm{~kg} \mathrm{ha}^{-1}$ did not show significant differences between them. When the $\mathrm{K}^{+}$losses were evaluated, there were no differences between $\mathrm{BS}, \mathrm{CB}, \mathrm{BB}$ and $\mathrm{CO}$ treatments, with the exception of the BB treatment, a fact that may have occurred due to the respective treatment being at the end of the vegetative cycle, something which provided sufficient leaf cover to minimize losses of this nutrient.

When evaluating the losses of organic carbon during August, it was observed that the greatest losses occurred for the treatment of BS with $1.875 \mathrm{~kg} \mathrm{ha}^{-1}$; there was no significant difference in the other treatments of $\mathrm{CB}, \mathrm{BB}, \mathrm{CO}$ or $\mathrm{SN}$. These results are mainly attributed to the physical barrier provided by the groundcover plants, reducing the kinetic energy of sediment transport in the runoff, making it difficult to break the aggregates. In the case of bare soil, the effect was inverted due to the absence of protection of the vegetal cover, which obviously provided greater losses of organic carbon. The results evidenced the need to adopt conservation practices that reduce water erosion, maintaining the organic fraction of soil, since it is important in maintenance of soil structure, moisture retention and cation exchange capacity, among other attributes, according to Silva et al. (2005a), mainly in the savanna soils of northern Amazonia.

\section{CONCLUSIONS}

1. The treatment of bare soil (BS), followed by the cultivated cowpea bean (CB) treatment, showed higher losses of soil, water, nutrients and organic carbon.

2. The highest losses of soil, water, nutrients and organic carbon in the treatment of bare soil (BS) occurred during the period of greatest erosivity, but for treatments of $\mathrm{CB}, \mathrm{BB}$ and $\mathrm{CO}$ it occurred during the establishment of the crop, in view of the lower soil cover.

3. Soils cultivated with Brachiaria brizantha - BB, corn - CO and the area with Savana Natural - SN, were more efficient in reducing soil and water losses during all months evaluated.

4. The plant covering produced by the treatments $\mathrm{SN}, \mathrm{BB}$ and $\mathrm{CO}$ acted to reduce the harmful effects of erosion, minimizing the losses of nutrients and organic carbon, differently from what happened in the bare soil (BS) treatment.

\section{IPABH}




\section{ACKNOWLEDGMENTS}

The authors would like to thank CAPES (Coordination of Improvement of Higher Level Personnel) for the scholarship granted to the first author's Master Degree in the Graduate Program in Agronomy (POSAGRO/UFRR).

\section{REFERENCES}

AGUIAR, M. I.; MAIA, S. M. F.; OLIVEIRA, T. S.; MENDONÇA, E. S.; ARAÚJO FILHO, J. A. Perdas de solo, água e nutrientes em sistemas agroflorestais no município de Sobral, CE. Revista Ciência Agronômica, v. 37, p. 270-278, 2006.

ALBUQUERQUE, A. W. et al. Parâmetros erosividade da chuva e da enxurrada correlacionados com as perdas de solo de um solo Bruno Não Cálcico de Sumé - PB. Revista Brasileira de Ciência do Solo, v. 22, n. 4, p. 743-749, 1998. http://dx.doi.org/10.1590/S0100-06831998000400020

ALBUQUERQUE, J. A.; ARGENTON, J.; BAYER, C.; WILDNER, L. P.; KUNTZE, M. A. G. Relação de atributos do solo com a agregação de um Latossolo Vermelho sob sistemas de preparo e plantas de verão para cobertura do solo. Revista Brasileira de Ciência do Solo, Viçosa, v. 29, n. 3, p. 415-424, 2005. http://dx.doi.org/10.1590/S010006832005000300012

ARAÚJO, W. F.; ANDRADE JÚNIOR, A. S.; MEDEIROS, R. D.; SAMPAIO, R. A. Precipitação pluviométrica mensal provável em Boa Vista, Estado de Roraima, Brasil. Revista Brasileira de Engenharia Agrícola e Ambiental, v. 5, n. 3, p. 563-567, 2001.

BARBOSA, R. I.; FEARNSIDE, P. M. Erosão do Solo na Amazônia: estudo de caso na região do apiaú, Roraima, Brasil. Acta Amazônica. v. 30, n. 4, p. 601-613, 2000. http://dx.doi.org/10.1590/1809-43922000304613

BARROS, L. S.; VALE JUNIOR, J. F.; SCHAEFER, C. E. G. R.; MOURÃO JUNIOR, M. Perdas de solo e água em plantio de Acacia mangium wild e savana em Roraima, norte da Amazônia. Revista Brasileira de Ciência do Solo, v. 33, n. 2, p. 447-454, 2009. http://dx.doi.org/10.1590/S0100-06832009000200022

BENEDETTI, U. G.; VALE JUNIOR, J. F.; SCHAEFER, C. E. G. R.; MELO, V. F.; UCHÔA, S. C. P. Gênese, química e mineralogia de solos derivados de sedimentos pliopleitocênicos e de rochas vulcânicas básicas em Roraima, norte Amazônico. Revista Brasileira de Ciência do Solo, v. 35, n. 1, p. 299-312, 2011. http://dx.doi.org/10.1590/S010006832011000200002

BERTOL, I.; COGO, N. P.; SCHICK, J.; GUADAGNIN, J. C.; AMARAL, A. J. Aspectos financeiros relacionados às perdas de nutrientes por erosão hídrica em diferentes sistemas de manejo do solo. Revista Brasileira de Ciência do Solo, v. 31, n. 1, p. 133-142, 2007. http://dx.doi.org/10.1590/S0100-06832007000100014

BERTONI, J.; LOMBARDI NETO, F. Conservação do solo. 8. ed. São Paulo: Ícone, 2012.

CABANÊZ, P. A.; FERRARI, J. L.; PAULA, M. F.; CABANÊZ, P. A. Precipitação efetiva: uma perspectiva para os estudos em Agroecologia. Revista Verde, v. 6, n. 5, p. 15-24, 2011. 
CARDOSO, D. P.; SILVA, M. L. N.; CARVALHO, G. J.; FREITAS, D. A. F.; AVANZI, J. C. Plantas de cobertura no controle das perdas de solo, água e nutrientes por erosão hídrica. Revista Brasileira de Engenharia Agrícola e Ambiental, v. 16, n. 6, p. 632-638, 2012. http://dx.doi.org/10.1590/S1415-43662012000600007

CARDOSO, D. P.; CARVALHO, G. J. SILVA, M. L. N.; FREITAS, D. A. F.; AVANZI, J. C. Atributos fitotécnicos de plantas de cobertura para a proteção do solo. Revista Verde, v. 8, n. 1, p. 19-24, 2013.

CARVAlHO, M. A. R.; MIRANDA, J. H.; DUARTE, S. N; CARVAlHO, L. C. C. Escoamento superficial na interação: cobertura vegetal e práticas de controle de erosão. Engenharia Agrícola, v. 32, n. 6, p. 1116-1125, 2012. http://dx.doi.org/10.1590/S010069162012000600013

CARVALHO, M. P.; LOMBARDI NETO, F.; VASQUES FILHO, J.; CATANEO, A. İndices de erosividade da chuva correlacionada com as perdas de um Podzólico Vermelho-amarelo eutrófico textura argilosa/muito argilosa de Mococa (SP): Primeira aproximação do fator erodibilidade dos solos. Revista Brasileira de Ciência do Solo, v. 13, n. 2, p. 237-242, 1989.

CASTRO, N. E. A.; SILVA, M. L. N.; FREITAS, D. A. F.; CARVALO, G. J.; MARQUES, R. M.; GONTIJO NETO, G. F. Plantas de cobertura no controle da erosão hídrica sob chuvas naturais. Bioscience Journal, v. 27, n. 5, p. 775-785, 2011.

COGO, N. P.; LEVIEN, R.; SCHWARZ, R. A. Perdas de solo e água por erosão hídrica influenciadas por métodos de preparo, classes de declive e níveis de fertilidade do solo. Revista Brasileira de Ciência do Solo, v. 27, n. 4, p. 743-753, 2003. http://dx.doi.org/10.1590/S0100-06832003000400019

CUNHA, J. M.; GAIO, D. C.; CAMPOS, M. C. C.; SOARES, M. D. R; SILVA, D. M. P; LIMA, A. F. L. Atributos físicos e estoque de carbono do solo em áreas de Terra Preta Arqueológica da Amazônia. Revista Ambiente \& Água. v. 12, n. 2, p. 263-281, 2017.

DECHEN, S. C. F.; TElleS, T. S.; GUIMARAES, M. F.; MARIA, I. C. Perdas e custos associados à erosão hídrica em função de taxas de cobertura do solo. Bragantia, v. 74, n. 2, p. 224-233, 2015. http://dx.doi.org/10.1590/1678-4499.0363

DIAS, A. C.; SILVA, M. L. N.; FREITAS, D. A. F.; BATISTA, P. V. G.; CURI, N.; CARVALHO, G. J. Soil cover plants on water erosion control in the South of Minas Gerais. Ciência e Agrotecnologia, v. 37, n. 5, p. 410-418, 2013. http://dx.doi.org/10.1590/S1413-70542013000500004

EMPRESA BRASILEIRA DE PESQUISA AGROPECUÁRIA - EMBRAPA. Manual de métodos de análise de solos. 2. ed. Rio de Janeiro: Embrapa Solos, 2011. 225 p.

EMPRESA BRASILEIRA DE PESQUISA AGROPECUÁRIA - EMBRAPA. Centro Nacional de Pesquisa de Solos. Sistema brasileiro de classificação de solos. 3. ed. Rio de Janeiro: Embrapa Solos, 2013. 353p.

EKHOLM, P.; LEHTORANTA, J. Does control of soil erosion inhibit aquatic eutrophication? Journal of Environmental Management, v. 93, p. 140-146, 2012. http://dx.doi.org/10.1016/j.jenvman.2011.09.010 
FEITOSA, K. K. A.; VALE JÚNIOR, J. F.; SCHAEFER, E. G. R.; SOUSA, M. I. L. NASCIMENTO, P. P. R. R. Relações solo-vegetação em "ilhas" florestais e savanas adjacentes, no nordeste de Roraima. Ciências Florestal, v. 26, n. 1, p. 135-146, 2016. http://dx.doi.org/10.5902/1980509821098

FERREIRA, D. F. SISVAR: um programa para análises e ensino de estatística. Revista Symposium, v. 6, p. 36-41, 2008.

FOSTER, G. R.; MCCOOL, D. K.; RENARD, K. G.; MOLDEBHAUER, W. C. Conversion of the universal soil loss equation to SI units. Journal of Soil and Water Conservation, v. 36, n. 6, p. 355-359, 1981.

GUADAGNIN, J. C.; BERTOL, I.; CASSOL, P. C.; AMARAL, A. J. Perdas de solo, água e nitrogênio por erosão hídrica em diferentes sistemas de manejo. Revista Brasileira de Ciência do Solo, v. 29, n. 2, p. 277-286, 2005. http://dx.doi.org/10.1590/S010006832005000200013

GUTH, P. L. Perdas de solo e água por erosão hídrica em sistemas de culturas oleaginosas. 2010. 85p. Dissertação (Mestrado) - Universidade Federal de Santa Maria, Santa Maria, 2010.

LEITE, M. H. S.; COUTO, E. G.; AMORIM, S. S. A.; COSTA, E. L.; MARASCHIN, L. Perdas de solo e nutrientes num Latossolo Vermelho-Amarelo Ácrico Típico, com diferentes sistemas de preparo e sob chuva natural. Revista Brasileira de Ciência do Solo, v. 33, n. 3, p. 689-699, 2009. http://dx.doi.org/10.1590/S0100-06832009000300021

LIMA, G. C.; SILVA, M. L. N.; CURI, N.; SILVA, M. A.; OLIVEIRA, A. H.; AVANZI, J. C.; UMMUS, M. E. Avaliação da cobertura vegetal pelo índice de vegetação por diferença normalizada (IVDN). Revista Ambiente \& Água, v. 8, n. 2, p. 204-214, 2013. http://dx.doi.org/10.4136/ambi-agua.959

MARIOTI, J.; BERTOL, I.; RAMOS, J. C.; WERNER, R. S.; PADILHA, J.; BANDEIRA, D. H. Erosão hídrica em semeadura direta de milho e soja nas direções da pendente e em contorno ao declive, comparada ao solo sem cultivo e descoberto. Revista Brasileira de Ciência do Solo, v. 37, n. 5, p. 1361-1371, 2013. http://dx.doi.org/10.1590/S010006832013000500025

MELO, V. F.; SCHAEFER, C. E. G. R.; VALE JÚNIOR, J. F.; UCHÔA, S. C. P. Aspectos pedológicos e de manejo dos solos de Roraima. In: MELO, V. F.; BARBOSA, R. I, Roraima: homem, ambiente e ecologia. Boa vista: Femact, 2010, p. 391-408.

OLIVEIRA, A. H.; SILVA, M. L. N.; CURI, N.; AVANZI, J. C.; NETO, G. K.; ARAÚJO, E. F. Water erosion in soils under eucalyptus forest as affected by development stages and management systems. Ciência e Agrotecnologia, v. 37, n. 1, p. 159-169, 2013. http://dx.doi.org/10.1590/S1413-70542013000200007

OLIVEIRA, L. C.; BERTOL, I.; BARBOSA, F. T.; CAMPOS, M. L.; MECABÔ JUNIOR, J. Perdas de solo, água e nutrientes por erosão hídrica em uma estrada florestal na serra Catarinense. Ciência Florestal, v. 25, n. 3, p. 655-665, 2015. http://dx.doi.org/10.5902/1980509819616

PANACHUKI, E.; BERTOL, I.; SOBRINHO, T. A.; OLIVEIRA, P. T. S.; RODRIGUES, D. B. B. Perdas de solo e de água e infiltração de água em latossolo vermelho sob sistemas de manejo. Revista Brasileira de Ciência do Solo, v. 35, n. 5, p. 1777-1785, 2011. http://dx.doi.org/10.1590/S0100-06832011000500032 
PANAGOS, P.; BORRELli, P.; MEUSBURGER, K.; ALEWELL, C.; LUGATO, E.; MONTANARELLA, L. Estimating the soil erosion cover-management factor at the European scale. Land Use Policy, v. 48, p. 38-50, 2015. http://dx.doi.org/10.1016/j.landusepol.2015.05.021

PIRES, L. S.; SILVA, M. L. N.; CURI, N.; LEITE, F. P.; BRITO, L. F. Erosão hídrica pósplantio em florestas de eucalipto na região centro-leste de Minas Gerais. Pesquisa Agropecuária Brasileira, v. 41, n. 4, p. 678-695, 2006. http://dx.doi.org/10.1590/S0100204X2006000400021

PUGLIESI, A. C. V.; MARINHO, M. A.; MARQUES, J. F.; LUCARELLI, J. R. F. Valoração econômica do efeito da erosão em sistemas de manejo do solo empregando o método custo de reposição. Bragantia, v. 70, n. 1, p. 113-121, p. 2011. http://dx.doi.org/10.1590/S000687052011000100017

RABELO, M. W. O.; GRIEBELER, N. P. Determinação de incremento de altura de camalhão na integração terraço-estrada. Pesquisa Agropecuária Tropical, v. 42, n. 1, p. 49-55, 2012. http://dx.doi.org/10.1590/S1983-40632012000100007

SANTOS, G. G.; GRIEBELER, N. P.; OLIVEIRA, L. F. C. Chuvas intensas relacionadas à erosão hídrica. Revista Brasileira de Engenharia Agrícola e Ambiental, v. 14, n. 2, p. 115-123, 2010. http://dx.doi.org/10.1590/S1415-43662010000200001

SCHICK, J.; BERTOL, I.; BALBINOT JÚNIOR, A. A.; BATISTELA, O. Erosão hídrica em

Cambissolo Húmico Alumínico submetido a diferentes sistemas de preparo e cultivo do solo: II. perdas de nutrientes e carbono orgânico. Revista Brasileira de Ciência do Solo, v. 24, n. 2, 575 p. 437-447, 2000. http://dx.doi.org/10.1590/S0100-06832000000200019

SHAMSHAD, A.; AZHARI, M. N.; ISA, M. H.; WAN HUSSIN, W. M. A.; PARIDA, B. P. Development of an appropriate procedure for estimation of RUSLE EI30 index and preparation of erosivity maps for Pulau Penang in Peninsular Malaysia. Catena, v. 72, n. 3, p.423-432, 2008.

SILVA, A. M.; SILVA, M. L. N; CURI, N.; LIMA, J. M.; AVANZI, J. C.; FERREIRA, M. M. Perdas de solo, água, nutrientes e carbono orgânico em Cambissolo e Latossolo sob chuva natural. Pesquisa Agropecuária Brasileira, v. 40, n. 12, p. 1223-1230, 2005 b. http://dx.doi.org/10.1590/S0100-204X2005001200010

SILVA, D. D.; PRUSKI, F. F.; SCHAEFER, C. E. G. R. Efeito da cobertura nas perdas de solo em um Argissolo Vermelho-Amarelo utilizando simulador de chuva. Engenharia Agrícola, v. 25, n. 2, p. 409-419. 2005a.

SOANE, B. D.; BALL, B. C.; ARVIDSSON, J.; BASCH, G.; MORENO, F.; ROGERESTRADE, J. No-till in northern, western and south-western Europe: a review of problems and opportunities for crop production and the environment. Soil \& Tillage Research, v. 118, p. 66-87, 2012. http://dx.doi.org/10.1016/j.still.2011.10.015

SOUSA, G. B.; MARTINS FILHO, M. V.; MATIAS, S. S. R. Perdas de solo, matéria orgânica e nutrientes por erosão hídrica em uma vertente coberta com diferentes quantidades de palha de cana-de-açúcar em Guariba - SP. Engenharia Agrícola, v. 32, n. 3, p. 490-500, 2012. http://dx.doi.org/10.1590/S0100-69162012000300008 
SPOHR, R. B.; CARLESSO, R.; GALLÁRRETA, C. G.; PRÉCHAC, F. G.; PETILLO, M. G. Modelagem do escoamento superficial a partir das características físicas de alguns solos do Uruguai. Revista Ciência Rural, v. 39, n. 1, p. 74-81, 2009. http://dx.doi.org/10.1590/S0103-84782009000100012

TELLES, T. S.; DECHEN, S. C. F.; SOUZA, L. G. A.; GUIMARAES, M. F. Valuation and assessment of soil erosion costs. Scientia Agricola, v. 70, n. 3, p. 209-216, 2013. http://dx.doi.org/10.1590/S0103-90162013000300010

VOLK, L. B. S.; COGO N. P. Erosão hídrica, em três momentos da cultura do milho, influenciada por métodos de preparo do solo e semeadura. Revista Brasileira de Ciência do Solo, v. 38, p. 565-574, 2014. http://dx.doi.org/10.1590/S0100-06832014000200021

WISCHMEIER, W. H.; SMITH, D. D. Rainfall energy and its relationship to soil loss. Transaction American Geophysical Union, v. 39, p. 285-291, 1958. http://dx.doi.org/10.1029/TR039i002p00285

WISCHMEIER, W. H.; SMITH, D. D. Predicting rainfall erosion losses. A guide to conservation planning. Washington: USDA Agriculture, 1978. (Handbook, 537).

YEOMANS, J. C.; BREMNER, J. M. A rapid and precise method for routine determination of organic carbon in soil. Communication in Soil Science and Plant Analysis, v. 19, p.1467-1476, 1988.

ZHOU, G. Y.; MORRIS, J. D.; YAN, J. H.; YU, Z. Y.; PENG, S. L. Hydrological impacts of reforestation with eucalypts and indigenous species: a case study in Southern China. Forest Ecology and Management, v. 167, n. 1, p. 209-222, 2002. http://dx.doi.org/10.1016/S0378-1127(01)006946 


Ambiente \& Água - An Interdisciplinary Journal of Applied Science
ISSN 1980-993X - doi:10.4136/1980-993X
www.ambi-agua.net
E-mail: ambi.agua@gmail.com

\title{
Using the pollutant load concept to assess water quality in an urban river: the case of Carahá River (Lages, Brazil)
}

ARTICLES doi:10.4136/ambi-agua.2252

Received: 09 Mar. 2018; Accepted: 18 Oct. 2018

\author{
Jessica Quinatto ${ }^{\circledR}$; Natan Liz De Nale Zambelli ${ }^{\circledR}$; Diego Hoefling Souza ${ }^{(}$; \\ Sílvio Luís Rafaeli Neto ${ }^{\circledR}$; Josiane Teresinha Cardoso ${ }^{\circledR}$; Everton Skoronski* ${ }^{*}$ \\ Universidade do Estado de Santa Catarina (UDESC), Lages, SC, Brasil \\ Departamento de Engenharia Ambiental e Sanitária. E-mail: je.quinatto@gmail.com, \\ natanzambelli@hotmail.com, diego.hoefling@gmail.com, silvio.rafaeli@udesc.br, \\ josiane.cardoso@udesc.br, skoronski@cav.udesc.br \\ "Corresponding author
}

\begin{abstract}
The objective of this study was to evaluate the water quality of Carahá River in Lages (Brazil), using the concept of pollutant load and comparing the results with the water quality index. Thirteen points along the river were selected and eight collections were carried out over a period of 16 months. The parameters analysed were those required for the calculation of the water quality index (WQI). Flow measurements were also carried out, which enabled the calculation of the polluting load. The results showed that the WQI score ranges between 24.95 at the source and peaks at 40 at the outlet. The water classification, therefore, ranges from "very bad" to "bad". The calculation of the pollutant load showed a constant disposal of contaminants into the river, which demonstrates that the quality of the water is continuously degraded. This information could not be obtained by analysing only the WQI, which presented a nearly constant quality at point 4 and beyond. The use of the calculation of pollutant load for Carahá River is, therefore, a tool for assessment of pollution that can provide more appropriate information for the water resources management.
\end{abstract}

Keywords: flow, pollutant load, urban river, water quality index.

\section{Avaliação da qualidade da água de um rio urbano utilizando o conceito de carga de poluentes: o caso do Rio Carahá (Lages, Brazil)}

\section{RESUMO}

O objetivo deste trabalho foi avaliar a qualidade da água do Rio Carahá no município de Lages (Brasil), utilizando o conceito de carga de poluentes e comparar a representação dos resultados com aquela expressa por meio do índice de qualidade da água. Para este estudo foram selecionados 13 pontos ao longo da calha do rio e realizadas 8 coletas durante o período de 16 meses. As análises realizadas envolveram os parâmetros necessários para o cálculo do índice de qualidade da água (IQA). Foram ainda realizadas medições de vazão, o que possibilitaram a realização do cálculo da carga poluidora. Os resultados do IQA mostraram que a pontuação varia entre 24,95 para a nascente, chegando a 40 no exutório da bacia, classificando a água de "péssima" a "ruim". O cálculo da carga orgânica demonstrou uma adição constante de poluentes ao rio, o que demonstra que a qualidade da água é continuamente degradada. Esta informação 
não foi possível de ser obtida analisando-se somente o IQA, o qual apresentou uma qualidade praticamente constante a partir do ponto 4. Desta forma, para o rio Carahá, a utilização do cálculo da carga constitui-se em uma ferramenta de avaliação da poluição que pode trazer informações mais adequadas para a gestão de deste recurso hídrico.

Palavras-chave: carga poluidora, índice de qualidade da água, rio urbano, vazão.

\section{INTRODUCTION}

One of the most widely used tools for the assessment of water quality in rivers is the water quality index (WQI). This index was developed from a mathematical relationship that transforms the result of various analyses of physical, chemical and microbiological parameters into a single number. This simplifies the quality evaluation of the fresh waters (Maane-Messai et al., 2010). This index is widely accepted, as it plays an important role in the process of translation, as a tool used to communicate water quality (Bhatti and Latif, 2011). The use of the WQI in studies of water quality has been widely addressed over a long period. As an example of preliminary work, Egborge and Benka-Coker (1986) carried out their studies in the Warri River, Nigeria. More recent studies, such as the Hou et al. (2016) study of the Yellow River and Sun et al. (2016) of the Courtyard River, both in China, and Abdel-Satar et al. (2017) study of the Nile River in Egypt, highlight that WQI is still a useful tool for water quality assessment.

Although the use of the WQI has been widely accepted in investigations that involve the assessment of the water quality of rivers, one issue that needs to be raised is, to what extent will flow measurement affect the water quality evaluation? In this respect, an alternative way to evaluate the effects of pollution in rivers is the use of the concept of pollutants load. However, the concept of the load has traditionally been used for the design of effluent treatment systems and is not commonly used in studies on water quality in rivers. The volumetric organic load, for example, is a fundamental parameter for the design of biological reactors for treating sewage and industrial effluents (Metcalf and Eddy, 2013). For the monitoring of water resources, the use of more widespread pollutant load is related to the calculation of the mass of suspended solids transported by water. This measure is an important indicator of soil loss and also the basis for the design and control of dams (Richards, 1998). According to this author, the knowledge of a load of suspended solids has a greater significance when compared to the concentration of these species.

Many researchers have addressed this issue in a similar manner. The following studies are some examples of investigations that were carried out: Ntengwe (2006) studied the Kitwe Stream in Zambia. The author investigated the levels of pollution, physical chemistry, biochemistry and the load of $\mathrm{BOD}_{5}$, phosphorus, nitrate, sulphate and suspended solids. Zhang et al. (2012) studied the pollution of Lake Taihu in China. Parameters such as chemical oxygen demand (COD), ammonia, total nitrogen and total phosphorus were evaluated in terms of the pollutant load. Wang et al. (2013) used the concept of load to evaluate the runoff of pollutants due to various land uses and occupation in Chongqing in China. The application of the concept of the load was used to check which activity has more intensely influenced the pollution of waters in that locality. Recently, Brodie et al. (2017) studied strategies to prioritize investments in pollution control on the Great Barrier Reef in Australia. The authors used the concept of load to evaluate which watersheds had the greatest influence on the pollution of reefs and used it to improve the effectiveness of programs for environmental protection. Finally, Li et al. (2019) applied the pollutant load concept to study benzene series in an urban environment.

Based on these studies, we can observe that the pollutant load concept has been considered by many authors as a tool for evaluating the impact of pollution in rivers. In addition, the Carahá 
River in the municipality of Lages (Brazil) has not been studied, despite the investigations carried out by Antunes et al. (2014). A gap therefore exists in the literature which must be filled by additional research on the Carahá River, so as to obtain useful data for public policy and environmental management. In this context, the objective of this study was to compare the water quality index to the concept of the load in a specific river and evaluate which methodology provides more substantial information.

\section{MATERIALS AND METHODS}

\subsection{Sample collection location}

The study was conducted along the Carahá River, in the municipality of Lages, located in the south of Brazil. The watershed of the Carahá River is at an average altitude of $988.32 \mathrm{~m}$. It has a surface area of $30.17 \mathrm{~km}^{2}$, about $58 \%$ of which is an urban area. In the basin, there are approximately forty thousand buildings, with an estimated population of 120,000 inhabitants. The watershed is roughly circular in shape, although its Shape Factor equals 0.59 and its Circularity of 1.89 indicates otherwise. This explains why the main channel of the basin is quite extensive in relation to its area, from where these coefficients derive. Although the average slope of the basin equals $7 \%$, indicating a smoothly undulating relief, the Carahá River basin has mountainous relief at its headwaters (the total altimetric range of the basin is $240.00 \mathrm{~m}$ in a total length of $6.8 \mathrm{~km}$ ). The longest flow path of the watershed is $9.7 \mathrm{~km}$, with the average sinuosity of $1.66 \mathrm{~km} \mathrm{~km}^{-1}$, which makes this channel a little winding, especially in the reach where it is channelled. The watershed of the Carahá River, therefore, is prone to generate large volumes of surface runoff from intense rainfall, which commonly cause flood disasters. The urban predominance also explains the possibility of finding high rates of pollution in the drainage channels.

The samples were taken every two months over a period of 16 months. Thirteen sampling points were selected, distributed to represent the various sub-watersheds according to Otto Pfafstetter, resulting in an approximate distance of 500 meters from one point to another as shown in Figure 1.

\subsection{Analytical methods}

The samplings were carried out in accordance with the procedures recommended by the standard guidelines for the collection and preservation of samples (American Public Health Association, 2005). The assessment of water quality was carried out according to physical, chemical and microbiological parameters. The analytical determinations were conducted in accordance with the methodologies described in the "Standard Methods for the Examination of Water and Wastewater" - SM (American Public Health Association, 2005). The parameters analysed were: thermotolerant coliforms (Method SM 9222 (D), biochemical oxygen demand - BOD5 (SM 5210 Method B), phosphorus (Method SM 4500-P (B and C), nitrite (SM 4500NO2- B), Total Kjeldahl Nitrogen - TKN (SM 4500-Norg C), dissolved oxygen (SM 4500-G), pH (SM 4500-H+ B), total dissolved solids - TDS (SM 2540 C), total suspended solids - TSS (SM 2540 (D) and temperature (SM 2550). The concentration of nitrate was determined by the method DIN (Deutsches Institut für Normung) 38405-9 (Deutsches Institut für Normung, 1979). The determination of total solids was computed by adding up the measures of total dissolved and suspended solids. The total nitrogen (TN) was calculated as the sum of TKN, nitrate and nitrite. 


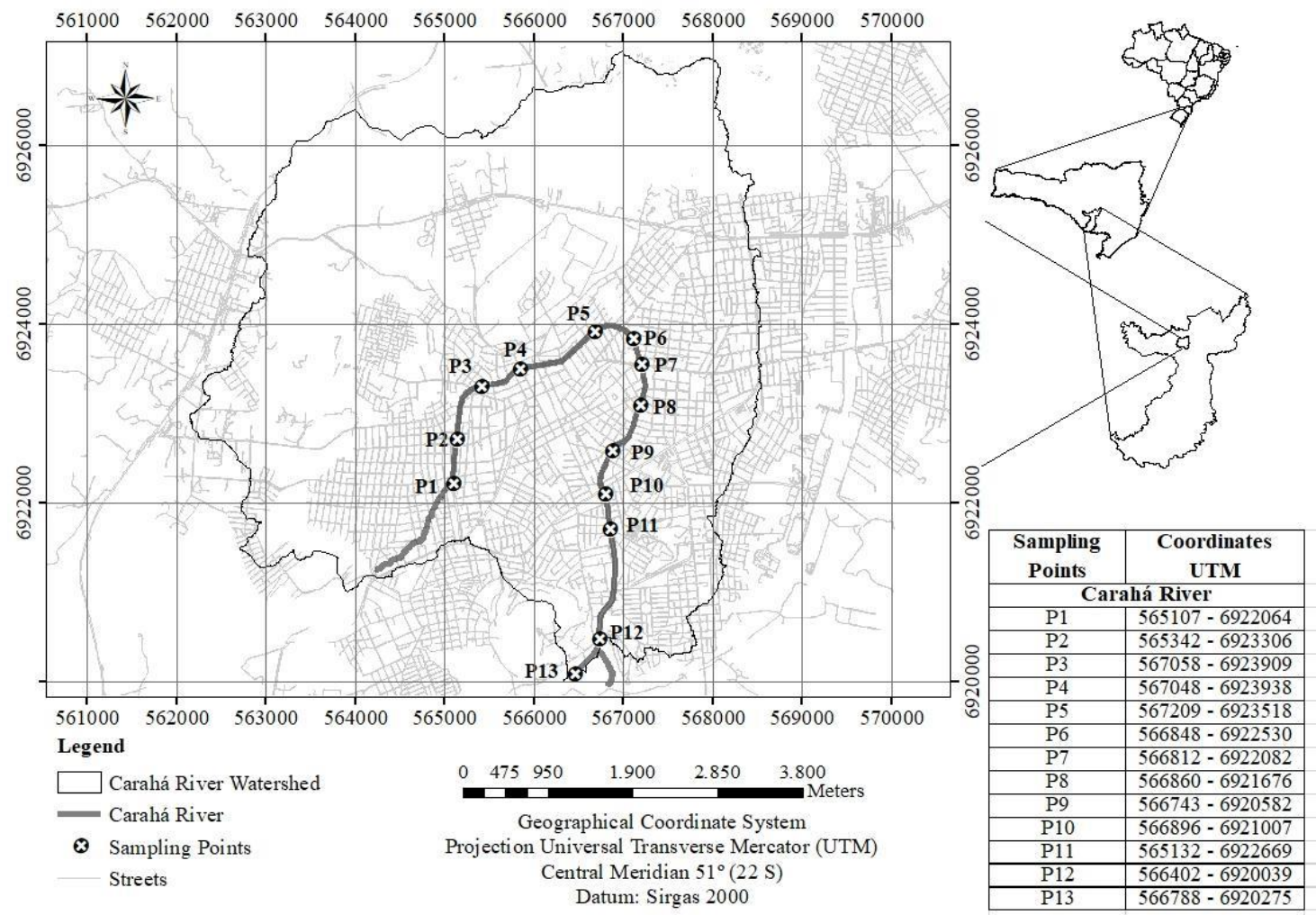

Figure 1. Map of Carahá River basin with the sampling points.

\subsection{Water quality index (WQI)}

The WQI was calculated by the weighted product of the scores attributed to each parameter of water quality mentioned above. The scores are assigned according to pre-established curves (Equation 1) (Ott, 1978).

$$
I Q A_{N S F}=\prod_{i=1}^{n} q_{i}^{w_{i}}
$$

Where:

IQA is the water quality index (ranging from 0 to 100);

$q_{i}$ is the score of parameter $i$, obtained by the specific curve;

$w_{i}$ : weight assigned to the parameter in function of its importance in quality (ranging from 0 to 1$)$.

The weights assigned to each parameter are the following (Ott, 1978): dissolved oxygen (0.17), thermotolerant coliforms $(0.15), \mathrm{pH}(0.12)$, biochemical oxygen demand $(0.10)$, phosphorus $(0.10)$, temperature $(0.10)$, total nitrogen $(0.10)$, turbidity $(0.08)$ and total solids (0.08). Ott (1978) suggests that the quality of water is expressed according to the following ranges of scores: very bad ( 0 to 25$)$, bad (26 to 50), medium (51 to 70), good (71 to 90 ) and excellent (91 to 100).

\subsection{Flow measurement and calculation of Load}

With regard to the flow measurement, this was performed in periods preceded by at least 72 hours with no precipitation. According to Padilha (2017), the time of concentration of the basin of the River Carahá is 4.73 hours. Considering the unitary hydrogram, the base time of the runoff in this basin corresponds to 39.6 hours, which implies that the measurements were 
performed approximately 32 hours after the end of runoff from rain effective. The measurements were carried out on three different days.

For this activity, a water flow meter (OTT Hydromet) was used at sampling points 1 to 12. First, the water velocity and depth was measured at many points along the margins. Then, the water flow was determined by multiplying the average velocity of the channel by the crosssectional area of flow. The measurement of the average velocity was performed at $60 \%$ below the water surface, according to guidelines suggested by Azevedo Netto et al. (1998).

The flow rate at point 13 was measured using an ADCP sensor (RiverRay), which communicates with WinRiver II software (Teledyne RD Instruments, 2016). The Q-boat 1800P (The Oceanscience Group, 2011) was used as a platform to drive the ADCP sensor in channel cross-section profiling.

Finally, after the determination of the concentration and flow data, it was possible to perform the calculation of pollutant load $F$ according to Equation 2.

$F=Q * C$

Where:

$F$ is the load $\left(\mathrm{g} \mathrm{h}^{-1}\right.$ or $\left.\mathrm{Kg} \mathrm{h}^{-1}\right)$

$Q$ is the flow rate $\left(\mathrm{L} \mathrm{h}^{-1}\right)$

$C$ is the concentration $\left(\mathrm{g} \mathrm{L}^{-1}\right.$ or $\left.\mathrm{Kg} \mathrm{L}^{-1}\right)$

\section{RESULTS AND DISCUSSION}

\subsection{Water quality index}

The results of the WQI showed that water quality at point 1 is classified as "very bad" and at points 2 to 13 as "bad" (Table 1). Overall, the scores were below 40, which shows that the land use and occupation on this watershed likely affect the water quality. Curiously, even the point at the source (Point 1) is strongly impacted mainly by domestic sewage disposal. As this point presents the lowest water flow, there is a minimal effect of dilution, and consequently the WQI was on average 24.89 , classifying the water at this point as "very bad". The municipality of Lages treats approximately $20 \%$ of all sewage, which may explain the predominance of water of "very poor" and "poor" quality. Among various types of environments and terrestrial landscapes, the urban rivers are the most used, occupied, modified, degraded, subjugated, and lastly, denied. In fact, there is a broad lack of environmental awareness from the society that inhabits its area. This is a problem which affects almost all developing countries.

Other authors studied several urban rivers and the obtained scores for the WQI are frequently similar. Souza et al. (2007), studied the Sal River in Sergipe, Brazil and classified its water as "very bad". Pontes et al. (2012) obtained a classification of "bad" to "good" for the Banguelo River, in the region of Contagem in Belo Horizonte, Brazil. In the study conducted by Sharma et al. (2014), the authors found that the Ganges River in Allahabad, India, was classified as "bad". Fia et al. (2015) studied the water body named "Ribeirão Vermelho" in Lavras, Brazil, and they obtained scores which classified it as "bad" to "medium".

Table 1 illustrates that WQI increases in the downstream direction from point 1 to 4 and it remains somewhat constant until the mouth. These results could probably be associated with the dilution effects along the river, and thus do not necessarily indicate an improvement of the water quality. This limitation is actually due to the WQI being calculated only by concentration measurements. This means that the impact of the water flow is not considered (Hoseinzadeh et al., 2015). 
Table 1. Average measurement results for parameters.

\begin{tabular}{|c|c|c|c|c|c|c|c|c|c|c|c|c|c|}
\hline \multirow{2}{*}{ Parameter } & \multicolumn{13}{|c|}{ Points } \\
\hline & 1 & 2 & 3 & 4 & 5 & 6 & 7 & 8 & 9 & 10 & 11 & 12 & 13 \\
\hline $\begin{array}{c}\mathrm{DO} \\
\left(\mathrm{mg} \mathrm{L}^{-1}\right)\end{array}$ & 3.08 & 2.80 & 3.61 & 3.59 & 4.09 & 3.86 & 4.04 & 3.92 & 4.14 & 4.46 & 4.39 & 3.37 & 3.35 \\
\hline $\begin{array}{c}\text { TC } \\
(\mathrm{CFU} / 100 \mathrm{~mL})\end{array}$ & $3.97 .10^{5}$ & $3.71 .10^{5}$ & $1.54 .10^{4}$ & $1.24 .10^{4}$ & $3.61 .10^{4}$ & $2.78 .10^{4}$ & $8.55 .10^{4}$ & $3.51 .10^{4}$ & $4.01 .10^{4}$ & $3.44 .10^{4}$ & $2.09 .10^{4}$ & $1.28 .10^{4}$ & $7.61 .10^{3}$ \\
\hline $\mathrm{pH}$ & 7.57 & 7.37 & 7.49 & 7.48 & 7.48 & 7.00 & 7.21 & 7.10 & 7.19 & 7.03 & 7.44 & 7.02 & 7.15 \\
\hline $\begin{array}{c}\mathrm{BOD}_{5} \\
\left(\mathrm{mg} \mathrm{L}^{-1}\right)\end{array}$ & 35.56 & 19.50 & 11.38 & 13.31 & 14.88 & 10.13 & 14.19 & 11.06 & 12.06 & 12.69 & 11.06 & 8.94 & 14.31 \\
\hline $\begin{array}{c}\mathrm{TP} \\
\left(\mathrm{mgP} \mathrm{L}^{-1}\right)\end{array}$ & 1.03 & 0.68 & 0.53 & 0.55 & 0.67 & 0.32 & 0.37 & 0.28 & 0.35 & 0.35 & 0.33 & 0.40 & 0.36 \\
\hline $\begin{array}{c}\mathrm{T} \\
\left({ }^{\circ} \mathrm{C}\right)\end{array}$ & 19.7 & 18.6 & 18.2 & 18.4 & 18.8 & 18.4 & 18.6 & 18.8 & 18.9 & 19.0 & 19.3 & 19.3 & 19.3 \\
\hline $\begin{array}{c}\mathrm{TN} \\
\left(\mathrm{mgN} \mathrm{L}^{-1}\right)\end{array}$ & 47.26 & 33.55 & 31.17 & 30.59 & 33.31 & 27.44 & 31.74 & 32.05 & 32.20 & 29.67 & 29.68 & 26.35 & 24.69 \\
\hline $\begin{array}{l}\text { Nitrate } \\
\left(\mathrm{mg} \mathrm{L}^{-1}\right)\end{array}$ & 4.55 & 2.93 & 4.15 & 4.10 & 4.58 & 3.43 & 3.98 & 6.16 & 5.21 & 3.73 & 3.78 & 4.11 & 4.29 \\
\hline $\begin{array}{l}\text { Nitrite } \\
\left(\mathrm{mg} \mathrm{L}^{-1}\right)\end{array}$ & 0.11 & 0.14 & 0.19 & 0.18 & 0.18 & 0.18 & 0.20 & 0.16 & 0.16 & 0.16 & 0.16 & 0.17 & 0.11 \\
\hline Turbidity (NTU) & 33 & 16 & 11 & 11 & 14 & 15 & 17 & 17 & 15 & 14 & 14 & 13 & 17 \\
\hline $\begin{array}{c}\mathrm{TS} \\
\left(\mathrm{mg} \mathrm{L}^{-1}\right)\end{array}$ & 319.16 & 216.60 & 178.67 & 185.29 & 192.79 & 164.62 & 162.17 & 162.68 & 160.67 & 169.12 & 239.92 & 139.27 & 164.83 \\
\hline WQI & 25 & 29 & 38 & 39 & 36 & 39 & 36 & 37 & 38 & 38 & 41 & 40 & 40 \\
\hline $\begin{array}{c}\text { Flow rate } \\
\qquad\left(\mathrm{L} \mathrm{s}^{-1}\right)\end{array}$ & 23.99 & 41.06 & 208.08 & 293.65 & 398.37 & 612.87 & 677.46 & 689.87 & 733.59 & 820.63 & 792.09 & 810.67 & 743.00 \\
\hline
\end{tabular}

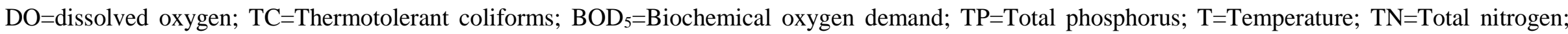
$\mathrm{TS}=$ Total solids. 


\subsection{Pollutant load}

Additionally, the pollutant load values were calculated with respect to some parameters such as BOD, phosphorus, TDS, TN, nitrite and nitrate. The concept of pollutant load involves the mass of a pollutant that is discharged into the water for a period of time (Metcalf and Eddy, 2013). The measurements of concentrations previously considered for WQI scores computing and the flow measurements were used to obtain the pollutant load values. The results are presented in Figure 2.

As can be seen in Figure 2A, the water flow increased gradually from nearly $24 \mathrm{~L} \mathrm{~s}^{-1}$ at the source and reached an average value of $743 \mathrm{~L} \mathrm{~s}^{-1}$ at the mouth, where it flowed towards Caveiras River.. Although the flows were measured on days which were not preceded by precipitation, a confidence interval that may reach $51.6 \%$ of average flow rate (point 11) was obtained, which demonstrates that the flow in the river is influenced by the discharge of raw sewage or even its disposal in urban drainage systems. The water flow showed insignificant variations from point 10 as this area has the lowest number of constructions in the watershed. These measurements of water flow allowed us to compute the pollutant load transported by the river. We observe from Figures $2 \mathrm{~B}$ to $\mathrm{F}$ that all the pollutant load values increase in the downstream direction, which certainly resulted from various contributions of sewage or wastewater along the river. With regard to the $\mathrm{BOD}_{5}$ (Figure 2B), the average pollutant load ranged between 3 to $39 \mathrm{Kg} \mathrm{h}^{-1}$ within the measurements. The municipality of Lages has a sewage treatment plant which partially receives all the sewage flow generated in the city (around 20\%). As a consequence, a large amount of the raw sewage is released into the Carahá River. Along with its extension, no recovery tendency was observed in the water quality due to the biological digestion (i.e. the $\mathrm{BOD}_{5}$ continuously increased to the mouth). This could be explained by the time of concentration in the River and the constant addition of organic pollutant load to the water.

Similarly, analysing the pollutant load of phosphorus and total nitrogen (Figures 2C and 2D), the values reached 1 and $80 \mathrm{Kg} \mathrm{h}^{-1}$, respectively. The control of the release of these nutrients into water bodies is of great concern to the basin management. The Caveiras River transports these nutrients to locations where there are dams built. In these places, the lentic ecosystem shows potential for eutrophication (Siziba, 2017). Therefore, knowledge of the phosphorus and nitrogen load permits the calculation of the mass of nutrients that will reach dams and thus assists in developing actions to control these releases. In this way, the measurement of pollutant load which is transported to the Caveiras River is more useful than the data based on concentration for Carahá River.

In addition, loads of nitrate and nitrite presented values equal to 11.48 and $0.30 \mathrm{Kg} \mathrm{h}^{-1}$ (Figures $2 \mathrm{E}$ and $2 \mathrm{~F}$ ), respectively, indicating that the sewage contamination is recent since these values are smaller than the load of the sum of organic nitrogen and total ammonia nitrogen (Von Sperling, 2005). Jani and Toor (2018) studied the Braden River, Manatee River, and Tampa Bay estuary in the United States of America, which is also mainly impacted by sewage disposal. The authors also concluded that organic nitrogen was the most common nitrogen form, ranging from 46 to $83 \%$. The inorganic nitrogen forms NOx accounted for $7 \%$. In addition, the authors discussed the effect of the dilution in the estuarine area by the tidal marine waters. The concentration of nitrogen decreased from freshwater to the estuarine ecosystem. In our study, we also observed a tendency for the nitrogen concentration decrease in the points close to the mouth, i.e. from point 10 (Table 1). As the Caveiras River is the water body used for freshwater abstraction, it is assumed to have a better water quality. Therefore, the dilution of the Carahá River in the mentioned points should occur. Alternatively, Li et al. (2019) carried out a study in the Xinjiang River, located in Southern China. The authors aimed to identify the sources and transformations of nitrate in the river. Many sources were identified, such as wastewater discharge and use of fertilizers. The concentration of nitrate was lower than 
$3.0 \mathrm{mg} \mathrm{L}^{-1}$, which was compatible with the values obtained in our study (Table 1). The authors used techniques based on nitrate isotopic signatures and were able to describe the nitrate transformations in the river. The results showed that $12 \%$ of the nitrate is removed by denitrification process in the river. Based on this result, the denitrification could be an effect which could explain the variation in the nitrate concentration in the sampling points close to the mouth of Carahá River. This observation corroborates with the load values for nitrate shown in Figure $2 \mathrm{~F}$. As the load is a parameter which is not influenced by the dilution effects, the decrease in nitrate load shown in Figure 2F must be due to denitrification.

A)
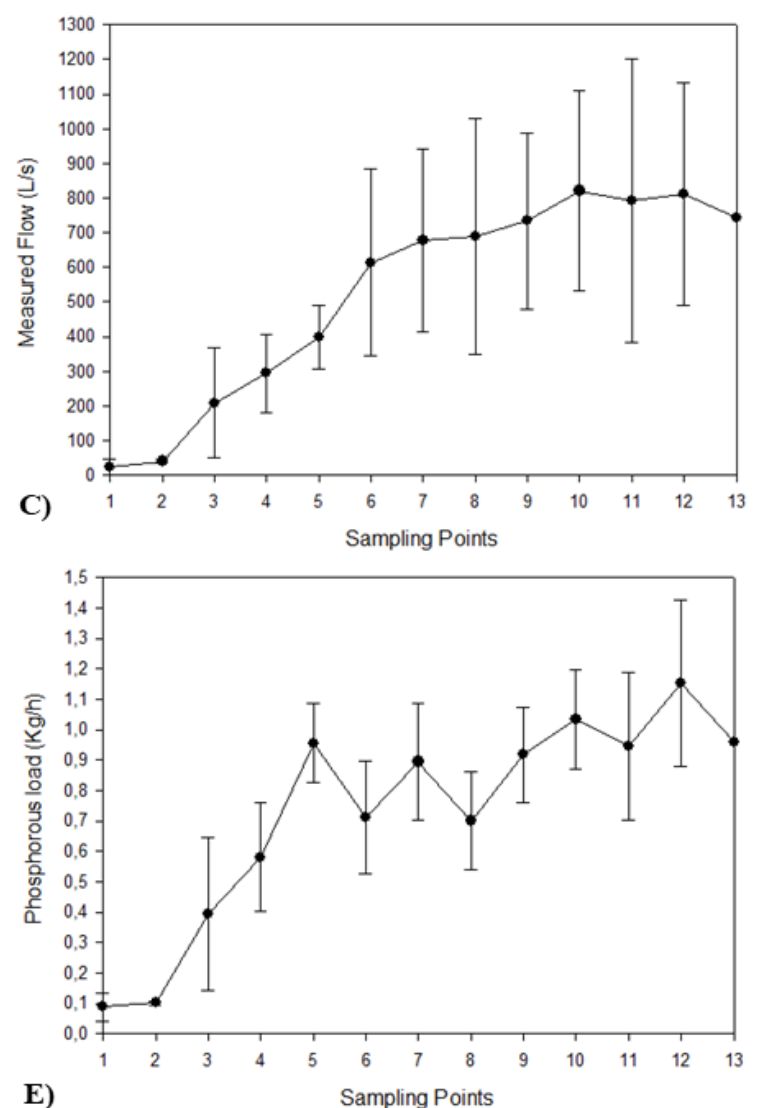

E)

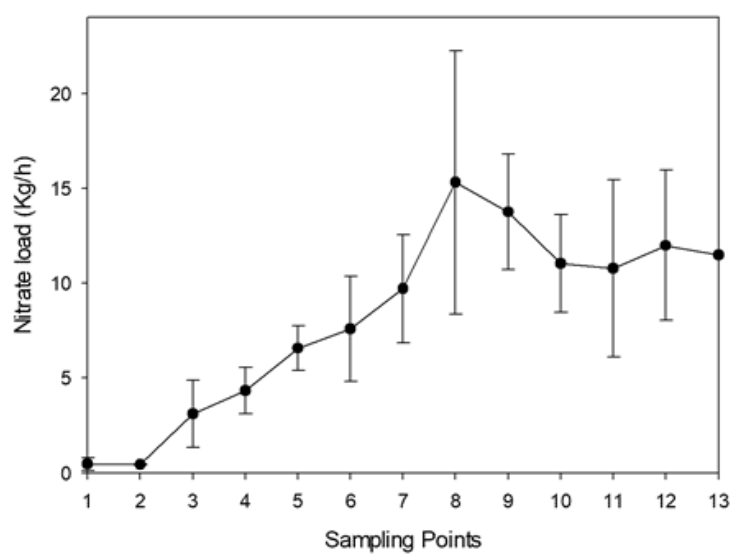

B)

D)
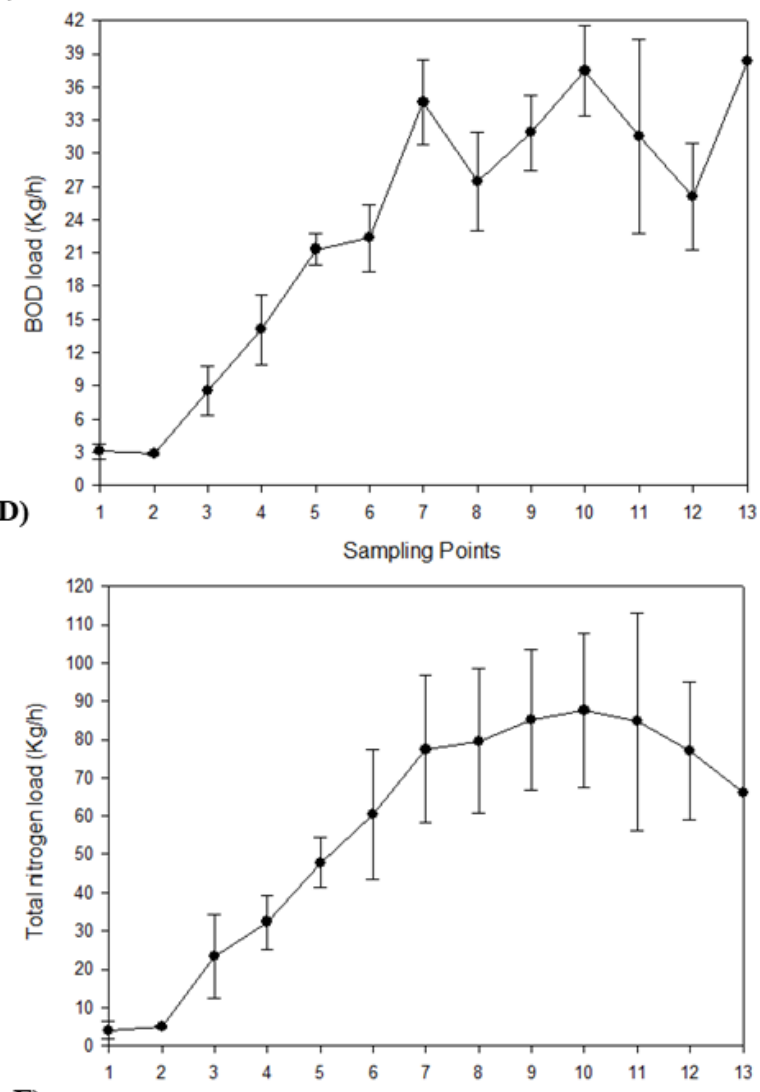

F)

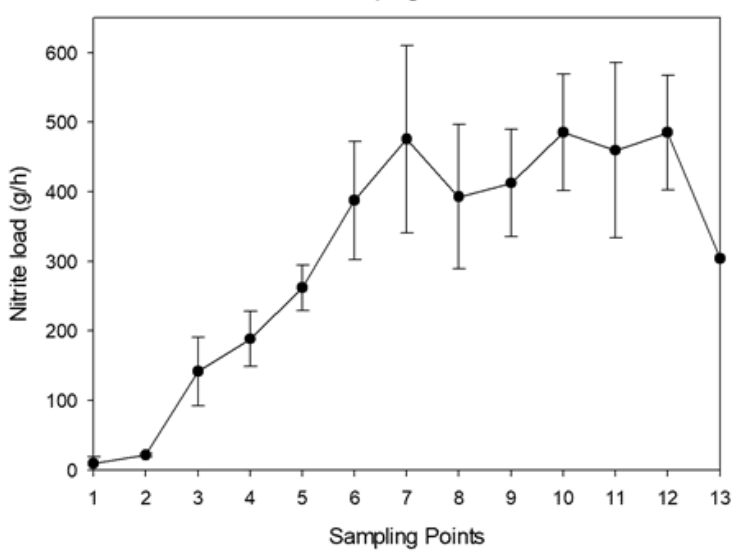

Figure 2. Flow measurements (A) and pollutant load for BOD (B), Phosphorous (C) and Total Kjeldahl Nitrogen (D).

Overall, it can be observed that there is an increase in the calculated load for the first sampling point in relation to the point at the mouth of the Carahá River. The concentration data 
presented in the form of WQI showed a constant behaviour of concentration from point 4 (Table 1), which creates the false impression that all points in the river have the same level of contamination. However, observing the data in Figure 2, it is possible to see an increase of up to 33 times, for instance, for the parameter nitrite. That is to say, the load transported $9.1 \mathrm{~g} \mathrm{~h}^{-1}$ of nitrite and the value reached $300 \mathrm{~g} \mathrm{~h}^{-1}$ at the mouth. From Figure 2, we can see more clearly the continuous increase in water contamination along the basin, in contrast to the results expressed by the water quality index. In other words, the use of concentration values and the consequent computing of WQI provided results that did not show the tendency of pollution increasing along the basin, which may generate misinformation about the impact on the water body.

\section{CONCLUSIONS}

The results obtained in this study showed that the monitoring of Carahá River by pollutant load concept is more representative of the environmental impacts once it is independent of the dilution effects. The river is increasingly impacted from the source to the outlet, which could be detected by the pollutant load values. On the other hand, the water quality index showed similar values and was not effective to express the progressive contamination in the watershed. The use of the calculation of load for Carahá River is, therefore, a tool for assessment of pollution that can provide more appropriate information for the management of this water resource.

\section{ACKNOWLEDGMENTS}

The authors would like to thank the Municipal Department for Environment from Lages/SC for the financial support for this project.

\section{REFERENCES}

ABDEL-SATAR, A. M.; ALI, M. H.; GOHER, M. E. Indices of water quality and metal pollution of Nile River, Egypt. The Egyptian Journal of Aquatic Research, v. 43, n. 1, p. 21-29, 2017. https://doi.org/10.1016/j.ejar.2016.12.006

AMERICAN PUBLIC HEALTH ASSOCIATION. Standard methods for the examination of water and wastewater. Washington, DC, 2005.

ANTUNES, C. M. M.; BITTENCOURT, S. C.; RECH, T. D. Qualidade das águas e percepção de moradores sobre um rio urbano. Revista Brasileira de Ciências Ambientais, v. 32, p. 76-87, 2014.

AZEVEDO NETTO, J. M. DE A.; FERNANDEZ, M. F. E.; ARAUJO, R. DE; ITO, A. E. Manual de Hidráulica. 8. ed. São Paulo: Blucher, 1998.

BHATTI, M. T.; LATIF, M. Assessment of water quality of a river using an indexing approach during the low flow season. Irrigation and Drainage, v. 60, n. 1, p. 103-114, 2011. https://doi.org/10.1002/ird.549

BRODIE, J. E.; LEWIS, S. E.; COLLIER, C. J.; WOOLDRIDGE, S.; BAINBRIDGE, Z. T.; WATERHOUSE, J. et al. Setting ecologically relevant targets for river pollutant loads to meet marine water quality requirements for the Great Barrier Reef, Australia: A preliminary methodology and analysis. Ocean \& Coastal Management, v. 143, p. 136147, 2017. https://doi.org/10.1016/j.ocecoaman.2016.09.028 
DEUTSCHES INSTITUT FÜR NORMUNG. DIN. 38405-9: German Standard Methods for Examination of Water, Waste Water And Sludge; Anions (group D), Determination of Nitrate Ion (d 9). Berlim, 1979.

EGBORGE, A. B. M.; BENKA-COKER, J. Water quality index: application in the Warri River, Nigeria. Environmental Pollution Series B, Chemical and Physical, v. 12, n. 1, p. 27 40, 1986. https://doi.org/10.1016/0143-148X(86)90004-2

FIA, R.; TADEU, H. C.; MENEZES, J. P. C. de; FIA, F. R. L.; OLIVEIRA, L. F. C. de. Qualidade da água de um ecossistema lótico urbano. Revista Brasileira de Recursos Hídricos, v. 20, n. 2, p. 267-275, 2015.

HOSEINZADEH, E.; KHORSANDI, H.; WEI, C.; ALIPOUR, M. Evaluation of Aydughmush river water quality using the national sanitation foundation water quality index (NSFWQI), river pollution index (RPI), and forestry water quality index (FWQI). Desalination and Water Treatment, v. 54, n. 11, p. 2994-3002, 2015. https://doi.org/10.1080/19443994.2014.913206

HOU, W.; SUN, S.; WANG, M.; LI, X.; ZHANG, N.; XIN, X. et al. Assessing water quality of five typical reservoirs in lower reaches of Yellow River, China: Using a water quality index method. Ecological indicators, v. 61, p. 309-316, 2016. https://doi.org/10.1016/j.ecolind.2015.09.030

JANI, J.; TOOR, G. S. Composition, sources, and bioavailability of nitrogen in a longitudinal gradient from freshwater to estuarine waters. Water Research, v. 137, p. 344-354, 2018. https://doi.org/10.1016/j.watres.2018.02.042

LI, C.; LI, S.; YUE, F.; LIU, J.; ZHONG, J.; YAN, Z. et al. Identification of sources and transformations of nitrate in the Xijiang River using nitrate isotopes and Bayesian model. Science of the Total Environment, v. 646, p. 801-810, 2019. https://doi.org/10.1016/j.scitotenv.2018.07.345

MAANE-MESSAI, S.; LAIGNEL, B.; MOTELAY-MASSEI, A.; MADANI, K.; CHIBANE, M. Spatial and temporal variability of water quality of an urbanized river in Algeria: The case of Soummam Wadi. Water Environment Research, v. 82, n. 8, p. 742-749, 2010. https://doi.org/10.2175/106143009X12465435982854

METCALF, L.; EDDY, H. P. Wastewater Engineering: Treatment and Resource Recovery. 5th ed. New York: McGraw-Hill Education, 2013.

NTENGWE, F. W. Pollutant loads and water quality in streams of heavily populated and industrialised towns. Physics and Chemistry of the Earth, Parts $\mathbf{A} / \mathbf{B} / \mathbf{C}$, v. 31, n. 1516, p. 832-839, 2006. https://doi.org/10.1016/j.pce.2006.08.025

OTT, W. R. Environmental indices: theory and practice. Ann Arbor: Ann Arbor Science Publishers, 1978.

PADILHA, V. L. Modelagem hidrológica orientada por eventos de inundação em Lages/SC. 2017. 174 p. Dissertação (Mestrado em Engenharia Ambiental) Universidade Federal de Santa Catarina, Santa Catarina, 2017.

PONTES, P. P.; MARQUES, A. R.; MARQUES, G. F. Efeito do uso e ocupação do solo na qualidade da água na micro-bacia do Córrego Banguelo-Contagem. Revista Ambiente \& Água, v. 7, n. 3, 2012. http://dx.doi.org/10.4136/ambi-agua.962 
RICHARDS, R. P. Estimation of pollutant loads in rivers and streams: A guidance document for NPS programs. Denver: USEPA, 1998. p. 108.

SHARMA, P.; MEHER, P. K.; KUMAR, A.; GAUTUM, Y. P.; MISHRA, K. P. Changes in water quality index of Ganges river at different locations in Allahabad. Sustainability of $\begin{array}{lllllll}\text { Water Quality and Ecology, } & \text { v. 3, p. 67-76, } 2014 .\end{array}$ https://doi.org/10.1016/j.swaqe.2014.10.002

SIZIBA, N. Effects of damming on the ecological condition of urban wastewater polluted $\begin{array}{llllll}\text { rivers. Ecological Engineering, v. 102, p. 234-239, } 2017 . & \end{array}$ https://doi.org/10.1016/j.ecoleng.2017.02.019

SOUZA, R. R. de.; COSTA, J. J.; SOUZA, R. M. e. Construção de modelo empírico para o monitoramento de recursos hídricos do Rio do Sal/Sergipe. Revista Brasileira de Ciências Ambientais, n. 8, p. 16-28, 2007.

SUN, W.; XIA, C.; XU, M.; GUO, J.; SUN, G. Application of modified water quality indices as indicators to assess the spatial and temporal trends of water quality in the Dongjiang $\begin{array}{llllll}\text { River. Ecological Indicators, } & \text { v. } & 66, \quad \text { p. } & 306-312,\end{array}$ https://doi.org/10.1016/j.ecolind.2016.01.054

THE OCEANSCIENCE GROUP. Q-BOAT 1800 User Guide. Cypress, 2011.

VON SPERLING, M. Introdução à qualidade das águas e ao tratamento de esgotos. Belo Horizonte: Editora UFMG, 1996.

WANG, S.; HE, Q.; AI, H.; WANG, Z.; ZHANG, Q. Pollutant concentrations and pollution loads in stormwater runoff from different land uses in Chongqing. Journal of Environmental Sciences, v. 25, n. 3, p. 502-510, 2013. http://dx.doi.org/10.1016/S10010742(11)61032-2

TELEDYNE RD INSTRUMENTS. Winriver II User Guide.Cypress, 2016.

ZHANG, R.; QIAN, X.; YUAN, X.; YE, R.; XIA, B.; WANG, Y. Simulation of water environmental capacity and pollution load reduction using QUAL2K for water environmental management. International journal of environmental research and $\begin{array}{lllllll}\text { public health, } & \text { v. } \quad 9, \quad \text { n. } & 12, & \text { p. 4504-4521, }\end{array}$ http://dx.doi.org/10.3390/ijerph91245041999. 


\begin{tabular}{|c} 
Ambiente \& Água - An Interdisciplinary Journal of Applied Science \\
ISSN 1980-993X - doi:10.4136/1980-993X \\
www.ambi-agua.net \\
E-mail: ambi.agua@gmail.com
\end{tabular}

\title{
Baker's yeast- $\mathrm{MnO}_{2}$ composites as biosorbent for Malachite green: An ecofriendly approach for dye removal from aqueous solution
}

\author{
ARTICLES doi:10.4136/ambi-agua.2254
}

Received: 13 Mar. 2018; Accepted: 01 Nov. 2018

\author{
Bruna Assis Paim dos Santos ${ }^{1}$; ; Aline Silva Cossolin ${ }^{1}$; \\ Hélen Cristina Oliveira dos Reis ${ }^{1}$; ; Ketinny Camargo de Castro ${ }^{1}(\mathbb{D}$; \\ Evanleide Rodrigues da Silva ${ }^{2}$; Gabriele de Menezes Pereira ${ }^{3}$; \\ Paulo Teixeira de Sousa Junior ${ }^{3}$; ; Evandro Luiz Dall'Oglio ${ }^{3}$ \\ Leonardo Gomes de Vasconcelos $^{3}$ iD ; Eduardo Beraldo de Morais ${ }^{1 * i D}$
}

\author{
${ }^{1}$ Universidade Federal de Mato Grosso (UFMT), Cuiabá, MT, Brasil \\ Departamento de Engenharia Sanitária e Ambiental (DESA). E-mail: bruna.santos_assis@ hotmail.com, \\ aline.cossolin@gmail.com, helenreis08@gmail.com, ketinnycamargo@gmail.com, \\ beraldo_morais@yahoo.com.br \\ ${ }^{2}$ Universidade Federal de Mato Grosso (UFMT), Cuiabá, MT, Brasil \\ Programa de Pós-Graduação em Recursos Hídricos (PPGRH). E-mail: evy_tha@ hotmail.com \\ ${ }^{3}$ Universidade Federal de Mato Grosso (UFMT), Cuiabá, MT, Brasil \\ Departamento de Química. E-mail: gabriele_menezzes@hotmail.com, pauloteixeiradesousa@gmail.com, \\ dalloglio.evandro@gmail.com, vasconceloslg@gmail.com \\ *Corresponding author
}

\begin{abstract}
In this study, baker's yeast- $\mathrm{MnO}_{2}$ composites, produced by direct oxidation of yeast with $\mathrm{KMnO}_{4}$ under acidic conditions, were used as biosorbent to remove the triphenylmethane dye Malachite green (MG) from an aqueous solution. Parameters that influence the adsorption process, such as $\mathrm{pH}$, contact time, temperature, initial dye concentration and biosorbent dosage, were evaluated in batch experiments. The optimum removal of $\mathrm{MG}$ was found to be $86.7 \mathrm{mg} \mathrm{g}^{-1}$ at $\mathrm{pH} 10,1.0 \mathrm{~g} \mathrm{~L}^{-1}$ of biomass dosage and $45^{\circ} \mathrm{C}$. The kinetic data of dye removal was better described by the pseudo-second-order model. The adsorption process followed the Langmuir isotherm model and the maximum biosorption capacity was estimated to be $243.9 \mathrm{mg} \mathrm{g}^{-1}$ (at $25^{\circ} \mathrm{C}$ ). The negative values of $\Delta G^{\circ}$ and the positive value of $\Delta H^{\circ}$ indicated that the $\mathrm{MG}$ biosorption onto yeast- $\mathrm{MnO}_{2}$ composites is spontaneous and endothermic. Fourier transform infrared spectroscopy (FTIR) indicated that the nano- $\mathrm{MnO}_{2}$ particles deposited on yeast- $\mathrm{MnO}_{2}$ composites surface facilitated the MG adsorption. It was concluded that baker's yeast- $\mathrm{MnO}_{2}$ composites have potential for application as adsorbent for removal of MG from aqueous solution.
\end{abstract}

Keywords: biosorption, isotherm and kinetic models, thermodynamic model. 


\section{Compósitos de $\mathrm{MnO}_{2}$-levedura de pão como biossorvente de verde Malaquita: uma abordagem ambientalmente amigável para a remoção de corante de solução aquosa}

\section{RESUMO}

Neste estudo, compósitos de $\mathrm{MnO}_{2}$-levedura de pão, produzidos pela oxidação direta da levedura com $\mathrm{KMnO}_{4}$ sob condições ácidas, foram usados como biossorvente para remover o corante trifenilmetano verde Malaquita (VM) de solução aquosa. Os parâmetros que influenciam o processo de adsorção tais como $\mathrm{pH}$, tempo de contato, temperatura, concentração inicial do corante e concentração do biossorvente foram avaliados em experimentos de bancada. As condições ótimas de descoloração foram observadas em pH 10 e concentração de biomassa igual a $1,0 \mathrm{~g} \mathrm{~L}^{-1}$. Os resultados de remoção do corante foram ajustados ao modelo cinético de pseudo segunda ordem. O processo de adsorção foi descrito pelo modelo isotérmico de Langmuir e a capacidade máxima de biossorção foi estimada em $243,9 \mathrm{mg} \mathrm{g}^{-1}$ (na temperatura de $25^{\circ} \mathrm{C}$ ). Os valores negativos de $\Delta G^{\circ}$ e valores positivos de $\Delta H^{\circ}$ indicaram que a biossorção do VM pelo compósito $\mathrm{MnO}_{2}$-levedura é espontâneo e endotérmico. A técnica de espectroscopia no infravermelho com transformada de Fourier indicou que nanopartículas de $\mathrm{MnO}_{2}$ depositadas na superfície do compósito $\mathrm{MnO}_{2}$-levedura facilitaram a adsorção do VM. Concluiu-se que o compósito $\mathrm{MnO}_{2}$-levedura de pão possui potencial para ser usado como adsorvente na remoção de VM de solução aquosa.

Palavras-chave: biossorção, modelos isotérmicos e cinéticos, modelo termodinâmico.

\section{INTRODUCTION}

Most dyes are synthetic chemicals widely used in textile, rubber, tanneries, paper, plastic, and paint industries for coloring purposes. It is estimated that there are more than 100,000 commercial dyes with a production of $7 \times 10^{5}-1 \times 10^{6} \mathrm{t}$ per year and approximately 280,000 $\mathrm{t}$ dyes are discharged together with industrial effluent annually worldwide (Fan et al., 2012). The presence of dyes in aquatic ecosystems is the cause of serious environmental and health concerns. The colored wastewaters do not only affect the transparency and aesthetics of natural water bodies, but also reduce photosynthesis by decreasing light penetration (Zhang et al., 2011). In addition, many dyes and their degradation products are potentially toxic, mutagenic and carcinogenic to living systems (Akar et al., 2015).

Some traditional chemical, physical and biological methods, such as coagulation, precipitation, ultrafiltration, electrolysis, color irradiation, ozonation and activated sludge have been employed for the treatment of dye-containing wastewater (Wu et al., 2011). However, there are disadvantages in all these methods, such as high cost, intensive energy requirements and formation of toxic by-products (secondary pollution) (Akar et al., 2009). On the other hand, biosorption technology utilizing different types of biomasses is an efficient and economic process to remove pollutants from wastewater. This is attributed to easy availability of some biosorbents, simplicity of design and operation and ability to treat wastewater with high concentration of pollutants (Castro et al., 2017). In the past decade, biosorbents including agroindustrial by-products (Akar et al., 2009), and biomass of algae (Khataee et al., 2013), filamentous fungi (Yang et al., 2011) and yeast (Castro et al., 2017) have been successfully applied to decolorize aqueous solutions and textile wastewater.

Baker's yeast (Saccharomyces cerevisiae) is an inexpensive and readily available source of biomass used to remove pollutants from wastewater. It has been used efficiently to remove radionuclides (Kedari et al., 2001), heavy metals (Xia et al., 2015) and textile dyes (Yu et al., 2009; Castro et al., 2017) with minimal or no impact to the environment. Biomass of $S$. 
cerevisiae can be produced cheaply using simple fermentation techniques or obtained as a waste from various industrial fermentation processes. Its dye-adsorptive ability is due to the chemical characteristics of its cell wall, which contains a high amount of polysaccharides, some proteins and other components. These biomacromolecules are sources of different functional groups such as amino, carboxyl, thiol, sulfhydryl and phosphate groups, which are responsible for dye adsorption (Fan et al., 2012). However, the amount of these functional groups on the biomass could be limited, and most biosorbents do not show a high sorption capacity for cationic dyes (Yu et al., 2009).

Since the adsorption of dyes takes place mainly on the biomass surface, current researches have focused on applying different chemical agents to modify the surface of biosorbents and to improve adsorption capacity. Yang et al. (2011) reported that modified biomass of Penicillium YW01with cetylpyridinium chloride significantly improved the adsorption of Acid Blue 25 dye from aqueous solution and phosphoric-phosphate buffer. Akar et al. (2015) showed that pretreatment of sugar-beet pulp with quaternary ammonium-salt is able to improve adsorption efficiency for Acid Red 1.

In this work, Malachite green (MG) dye was used as a model compound. MG is a cationic triphenylmethane dye also called Basic Green 4. It is extensively used in the pigment industry, having numerous applications in paper printing, textile industry, and in leather and cosmetics manufacturing. Furthermore, MG is also used as a topical antiparasitic and antiprotozoal agent in aquaculture (Chowdhury and Saha, 2010). However, it has been found that MG is environmentally persistent and causes carcinogenesis, mutagenesis, chromosomal fractures, teratogenicity and respiratory toxicity (Baek et al., 2010). Despite this, due to its availability and low cost, it is still widely used.

This study evaluated the capability of baker's yeast- $\mathrm{MnO}_{2}$ composites (yeast- $\mathrm{MnO}_{2}$ composites) to remove MG from an aqueous solution under different experimental conditions, such as initial $\mathrm{pH}$, contact time, temperature, dye concentration and biosorbent dosage. In order to obtain a better understanding of the biosorption mechanisms for future applications in real scale, the kinetics, isotherm and thermodynamics of dye removal were also studied. The preparation of yeast- $\mathrm{MnO}_{2}$ composites was first described by Xia et al. (2015) and involved the direct oxidation of baker's yeast biomass with $\mathrm{KMnO}_{4}$ under acidic conditions. This modification was first tested for $\mathrm{Cd}^{2+}$ removal and to the best of our knowledge, it has not been used yet for cationic dye removal from aqueous solutions.

\section{MATERIAL AND METHODS}

\subsection{Baker's yeast, reagents and preparation of yeast- $\mathrm{MnO}_{2}$ composites}

Baker's yeast was purchased from a commercial market. It was washed several times with ultra-pure water to remove dirt and soluble impurities, and then dried at $80^{\circ} \mathrm{C}$ for $48 \mathrm{~h}$. The powdered biomass was crushed and sieved to select particle fractions of less than $300 \mu \mathrm{m}$ using an ASTM Standard sieve and then stored in desiccators for further use.

Stock solution of MG (1000 mg/L) was prepared using ultra-pure water and was used to prepare the aqueous solutions used in biosorption experiments. MG was purchased from VETEC - Sigma-Aldrich, Brazil. All other chemicals used were of analytical grade.

To prepare the yeast- $\mathrm{MnO}_{2}$ composites, $20 \mathrm{~g}$ of baker's yeast was added to a $200 \mathrm{~mL} \mathrm{KMnO}_{4}(0.05 \mathrm{M})$ solution and the solution $\mathrm{pH}$ was adjusted to 2.0 , using $\mathrm{HCl}(0.1 \mathrm{M})$ (Xia et al., 2015). The mixture was then agitated on a rotary shaker at $300 \mathrm{rpm}$ for $30 \mathrm{~min}$. The suspension was centrifuged (3600 rpm, $15 \mathrm{~min}$ ) and biomass was washed repeatedly using ultrapure water several times to remove the residual $\mathrm{KMnO}_{4}$. Lastly, the biomass was dried at $80^{\circ} \mathrm{C}$ for $48 \mathrm{~h}$, sieved to select particle fractions of less than $300 \mu \mathrm{m}$ using an ASTM Standard sieve, and stored in desiccators for further use in biosorption tests.

\section{IPABH}

Rev. Ambient. Água vol. 14 n. 1, e2254 - Taubaté 2019 


\subsection{Batch biosorption experiments}

Experiments were conducted with $150 \mathrm{~mL}$ Erlenmeyer flasks containing a $50 \mathrm{~mL}$ aqueous solution of MG. Flasks were agitated on a rotary shaker at $120 \mathrm{rpm}$ and $25^{\circ} \mathrm{C}$. Because adsorption is directly influenced by physicochemical variables, variables such as different $\mathrm{pH}$ $(2,4,6,8$ and 10 , adjusted by the addition of $0.1 \mathrm{M} \mathrm{HCl}$ or $0.1 \mathrm{M} \mathrm{NaOH}$ solutions), initial dye concentration $\left(100,150,200,250,300\right.$ and $\left.350 \mathrm{mg} \mathrm{L}^{-1}\right)$, biosorbent dosage $(1.0,1.5,2.0$ and $3.0 \mathrm{~g}$ biomass $\left.\mathrm{L}^{-1}\right)$ and temperature $\left(25,35\right.$ and $\left.45^{\circ} \mathrm{C}\right)$ were evaluated. At the end of each equilibrium experiment, the biosorbent was removed from the suspension by centrifugation (3600 rpm, $15 \mathrm{~min}$ ) and the residual dye in the solution was measured quantitatively by a UVVis spectrophotometer (Hach DR6000) at $\lambda_{\max }=617 \mathrm{~nm}$. All biosorption experiments were performed in triplicate and the dye removal efficiency, R $(\%)$, and dye biosorption capacity $\left(q_{e}\right.$, $\mathrm{mg} \mathrm{g}^{-1}$ ) of biomass at the equilibrium were calculated according to Equations 1 and 2, respectively:

$$
\begin{aligned}
& R(\%)=\frac{C_{i}-C_{e}}{C_{i}} \times 100 \\
& q_{e}=\frac{\left(C_{i}-C_{e}\right)}{B}
\end{aligned}
$$

Where $C_{i}$ and $C_{e}$ are the initial and the equilibrium dye concentrations $\left(\mathrm{mg} \mathrm{L}^{-1}\right)$ and $B$ is the biosorbent concentration in solution $\left(\mathrm{g} \mathrm{L}^{-1}\right)$.

\subsection{FTIR analysis}

Fourier transform infrared spectroscopy (FTIR) analyses were performed on a Shimadzu Iraffinity-1 spectrophotometer (Model: IRAffinity-1; Catalogue Number: 206-73500-38; Serial Number: A21374902249S1; Brand: Shimadzu Corporation). FTIR was used to determine the functional groups on the yeast- $\mathrm{MnO}_{2}$ composites and their responsibility for MG adsorption. After adsorption of MG until equilibrium, the residual dye solution was centrifuged ( $3600 \mathrm{rpm}$, $15 \mathrm{~min}$ ), the supernatant was discarded and the residual biosorbent dried at $80^{\circ} \mathrm{C}$ for $48 \mathrm{~h}$ after being washed with ultra-pure water three times. The samples (1 mg biosorbent) were mixed with spectroscopically pure $\mathrm{KBr}(100 \mathrm{mg})$, and pellets were fixed in a sample holder. The qualitative analyses were carried out using the following parameters: Measured Mode (\% Transmittance), Apodization (Happ_Genzel), Number of Scans (200), Resolution (16), Range (400 a $4700 \mathrm{~cm}^{-1}$ ), Gain (1). The acquisitions of spectra were made using IRSolution software (Version 1.50). The background obtained from $\mathrm{KBr}$ disks was automatically subtracted from the sample disks spectra.

\section{RESULTS AND DISCUSSION}

\subsection{Effect of initial pH}

The $\mathrm{pH}$ is an important factor affecting the biosorption process since it influences the dye solubility and the ionizing functional groups of the biosorbent cell wall (Khataee et al., 2013). The $\mathrm{pH}$ also affects the structural stability of MG, and therefore its color intensity. Chen et al. (2014) observed color reduction when solution $\mathrm{pH}$ was more than 10 and lower than 2 . Consequently, in our study the initial $\mathrm{pH}$ ranges from 2 to10. Figure 1 illustrates the effect of different initial $\mathrm{pH}$ on the removal of $\mathrm{MG}$ by untreated baker's yeast and yeast- $\mathrm{MnO}_{2}$ composites at a dye concentration of $100 \mathrm{mg} \mathrm{L}^{-1}$ for $60 \mathrm{~min}, 25^{\circ} \mathrm{C}$ and $1.0 \mathrm{~g}$ biosorbent $\mathrm{L}^{-1}$. As the $\mathrm{pH}$ of the aqueous solution increased, the removal of MG by two biosorbents also increased. This effect is related to the deprotonation of different functional groups on the surface of the biomass with increasing $\mathrm{pH}$, which increases the net electronegativity of the biosorbent (Wu et al. 2011). Therefore, the electrostatic interactions between the negatively charged biosorbent 
and the positively charged MG dye cations lead to dye removal from the solution. Figure 1 also shows that MG removal efficiency of yeast- $\mathrm{MnO}_{2}$ composites was higher than the removal efficiency of untreated baker's yeast. This is explained by the destruction of yeast cell walls and the exposure of more functional groups during oxidation with $\mathrm{KMnO}_{4}$ and the nano- $\mathrm{MnO}_{2}$ particles that are deposited on yeast surface, which can facilitate the biosorption of dye (Xia et al., 2015). Since the greatest removal efficiency was observed at $\mathrm{pH} 10$, this $\mathrm{pH}$ was used in subsequent experiments.

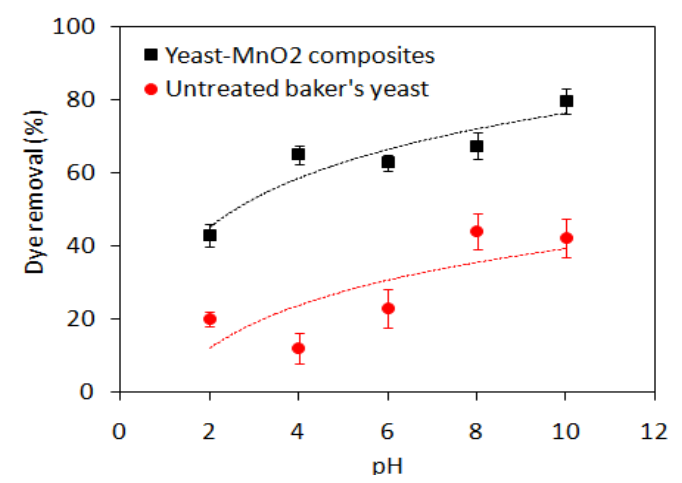

Figure 1. Effect of $\mathrm{pH}$ on the biosorption of MG by untreated baker's yeast and yeast- $\mathrm{MnO}_{2}$ composites (biosorbent dosage $=1.0 \mathrm{~g} \mathrm{~L}^{-1}$, dye concentration $=$ $100 \mathrm{mg} \mathrm{L}^{-1}$, contact time $=60 \mathrm{~min}$, temperature $=25^{\circ} \mathrm{C}$ ).

\subsection{Effect of contact time}

Considering the practical application, the ideal biosorption materials should be capable of rapidly adsorbing high concentrations of dyes from the wastewater and establishing equilibrium (Khataee et al., 2013). Therefore, the influence of the contact time on the MG biosorption capacity by yeast- $\mathrm{MnO}_{2}$ composites was tested at 25,35 and $45^{\circ} \mathrm{C}$ by varying the contact time between 10 and $120 \mathrm{~min}$. Figure 2 shows that for the given temperatures, a rapid biosorption of MG occurred at 10 min and was gradually slowed down until equilibrium, which was achieved at 50-60 min. Also, it can be seen that the equilibrium biosorption capacity of yeast- $\mathrm{MnO}_{2}$ composites increased from 86.5 to $95.7 \mathrm{mg} \mathrm{g}^{-1}$ when the temperature was increased from 25 to $45^{\circ} \mathrm{C}$. An increase in MG biosorption capacity of the biosorbent with temperature indicates that the biosorption of $\mathrm{MG}$ on yeast- $\mathrm{MnO}_{2}$ composites is kinetically controlled by an endothermic process.

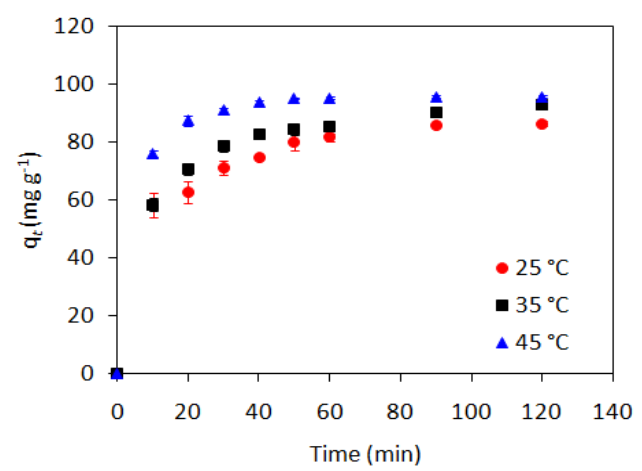

Figure 2. Effect of contact time on the biosorption of $\mathrm{MG}$ by yeast- $\mathrm{MnO}_{2}$ composites at different temperatures $(\mathrm{pH}$ $=10$, biosorbent dosage $=1.0 \mathrm{~g} \mathrm{~L}^{-1}$, dye concentration $=100 \mathrm{mg} \mathrm{L}^{-1}$ ). 


\subsection{Effect of biosorbent dosage}

Figure 3 illustrates the effect of biosorbent dosage on the biosorption of MG. As can be seen, the percentage of removal increased when the biomass dosage rose from 1.0 to $1.5 \mathrm{~g} \mathrm{~L}^{-1}$. A further increase in the biomass amount $\left(2.0\right.$ and $\left.3.0 \mathrm{~g} \mathrm{~L}^{-1}\right)$, however, caused no significant change in dye removal. On the order hand, the biosorption capacity decreased from 86.5 to $34.1 \mathrm{mg} \mathrm{g}^{-1}$ when the biomass dosage increased from 1.0 to $3.0 \mathrm{~g} \mathrm{~L}^{-1}$. The decrease in the biosorption capacity at higher yeast- $\mathrm{MnO}_{2}$ composite dosages can be attributed to the adsorption sites that remained unsaturated during the adsorption reaction, whereas the number of sites available for adsorption is increased by increasing the biosorbent dosage (Castro et al., 2017).

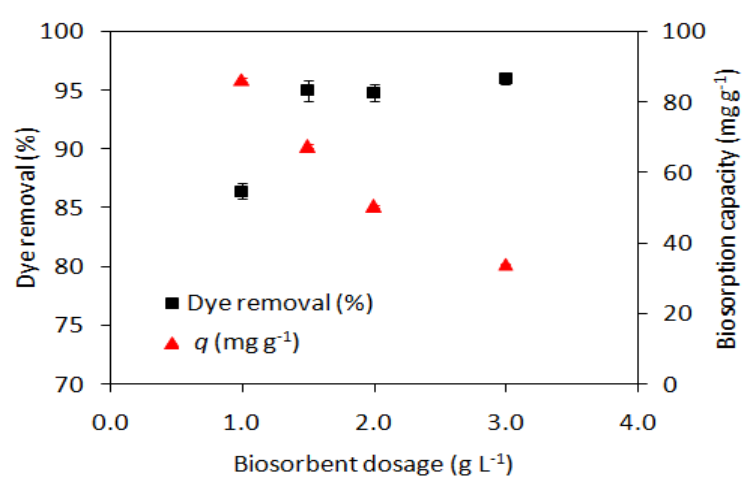

Figure 3. Effect of biosorbent dosage on the biosorption of $\mathrm{MG}$ by yeast- $\mathrm{MnO}_{2}$ composites (dye concentration $=100 \mathrm{mg} \mathrm{L}^{-1}$, contact time $=$ $120 \mathrm{~min}, \mathrm{pH}=10$, temperature $=25^{\circ} \mathrm{C}$ ).

\subsection{Effect of initial concentration of dye}

The initial concentration of dye provides an important driving force to overcome all mass transfer resistances of the dye between the aqueous and the solid phases (Khataee et al., 2013). In this study, MG biosorption capacity of the yeast- $\mathrm{MnO}_{2}$ composites was investigated using solutions of dye that ranged from 100 to $350 \mathrm{mg} \mathrm{L}^{-1}$ and temperature of $25^{\circ} \mathrm{C}$. The results in Figure 4 indicated that dye removal efficiency decreased with the increase in the initial dye concentration. On the other hand, biosorption capacity was increased and reached a maximum value of $214.1 \mathrm{mg} \mathrm{g}^{-1}$ at an MG initial concentration of $300 \mathrm{mg} \mathrm{L}^{-1}$. MG removal efficiency was higher at lower initial dye concentrations because all dye molecules may interact with the binding sites on the cell surface, while at higher dye concentrations, the binding sites on the biosorbent surface are saturated and no further biosorption occurs. A decrease in the biosorption capacity observed at a concentration of $350 \mathrm{mg} \mathrm{L}^{-1}$ when compared to concentration of $300 \mathrm{mg} \mathrm{L}^{-1}$ can be related to the repulsive forces between the dye molecules at the adjacent sites on the cell surface, which lead to a removal of some dye molecules from the surface (Castro et al., 2017).

\subsection{Biosorption kinetics}

Since sorption is a time-dependent process, the kinetic rate must be known for the design and evaluation of sorbents. In this study, kinetic studies of MG removal were conducted with a constant initial dye concentration $\left(100 \mathrm{mg} \mathrm{L}^{-1}\right), 1.0 \mathrm{~g}$ biosorbent $\mathrm{L}^{-1}$, at temperatures of 25,35 and $45^{\circ} \mathrm{C}$. The most-used kinetic models, including pseudo-first order, pseudo-second order and intraparticle diffusion, were applied to the experimental data from the MG biosorption experiments (Chowdhury and Saha, 2010). 


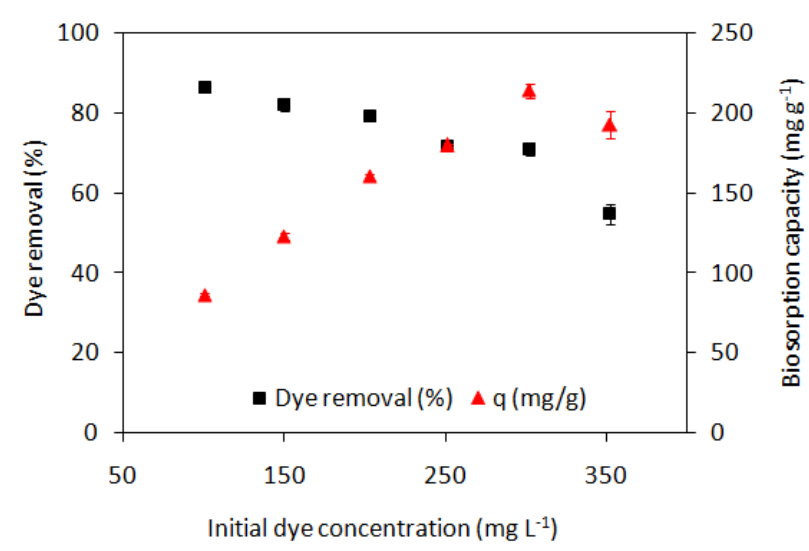

Figure 4. Effect of initial dye concentration on the biosorption of $\mathrm{MG}$ by yeast- $\mathrm{MnO}_{2}$ composites (biosorbent dosage $=1.0 \mathrm{~g}$ biomass $\mathrm{L}^{-1}$, dye concentration $=100 \mathrm{mg} \mathrm{L}^{-1}$, contact time $=120 \mathrm{~min}$, temperature $=25^{\circ} \mathrm{C}$ ).

The linear form of the pseudo-first order model is represented by Equation 3:

$\log \left(q_{e}-q_{t}\right)=\log q_{e}-\frac{K_{1}}{2.303} t$

Where $q_{e}$ and $q_{t}$ are the amounts of dye adsorbed by biosorbent $\left(\mathrm{mg} \mathrm{g}^{-1}\right)$ at equilibrium and at time $t$ ( $\mathrm{min})$, respectively, and $K_{1}$ is the pseudo-first order rate constant $\left(\mathrm{min}^{-1}\right)$. The values of $K_{1}$ and the predicted $q_{\mathrm{e}}$ were determined from the plot of $\log \left(q_{e}-q_{t}\right)$ against $t$.

The linear form of the pseudo-second order model can be expressed as in Equation 4:

$\frac{t}{q_{t}}=\frac{1}{K_{2} q_{e}^{2}}+\frac{1}{q_{e}} t$

Where $q_{e}$ and $q_{t}$ are the amounts of dye adsorbed by biosorbent $\left(\mathrm{mg} \mathrm{g}^{-1}\right)$ at the equilibrium and at time $t$ (min), respectively, and $K_{2}$ is the pseudo-second order rate constant $\left(\mathrm{g} \mathrm{mg}^{-1} \mathrm{~min}^{-1}\right)$. From the plot of $t / q_{t}$ against $t$, the model's parameters $K_{2}$ and $q_{\mathrm{e}}$ could be determined.

The intraparticle diffusion model allows for the identification of the diffusion mechanisms and can be represented by Equation 5:

$q_{t}=K_{i d} t^{0.5}+C$

Where $C$ is the intercept $\left(\mathrm{mg} \mathrm{g}^{-1}\right)$ and $K_{\text {id }}$ is the intraparticle diffusion rate constant ( $\mathrm{mg} \mathrm{g}^{-1} \min ^{-0.5}$ ). By plotting $q_{t}$ versus $t^{0.5}$, the values of $K_{\text {id }}$ and $C$ could be obtained. If the plot crosses the origin $(C=0)$, the adsorption process is controlled only by intraparticle diffusion.

The kinetic parameters for the MG biosorption for different temperatures are given in Table 1. Although the pseudo-first order model resulted in good fits $\left(R^{2}>0.964\right.$, Figure 5a and Table 1), the experimental $q_{e}$ values $\left(86.5,92.5\right.$ and $95.7 \mathrm{mg} \mathrm{g}^{-1}$ at 25,35 and $\left.45^{\circ} \mathrm{C}\right)$ did not agree with the calculated ones $\left(62.66,41.02\right.$ and $30.39 \mathrm{mg} \mathrm{g}^{-1}$ at 25,35 and $\left.45^{\circ} \mathrm{C}\right)$. The pseudosecond order model, on the order hand, resulted in the best fits $\left(R^{2}=0.999\right.$ for all temperatures studied, Figure 5b) and the biosorption capacities $\left(q_{2}\right)$ estimated were much closer to experimental $q_{e}$ values (Table 1). When increasing the temperature, the pseudo-second order

\section{IPABH}

Rev. Ambient. Água vol. 14 n. 1, e2254 - Taubaté 2019 
rate constant values changed from $1.32 \times 10^{-3}$ to $4.75 \times 10^{-3}\left(\mathrm{~g} \mathrm{mg}^{-1} \mathrm{~min}^{-1}\right)$. Similar results have been reported in the literature (Khataee et al., 2013; Wu et al., 2011). In the case of the intraparticle diffusion model, the biosorption results showed similar overall features of multilinear plots with two steps (Figure 5c). The first step is attributed to the external surface adsorption or instantaneous diffusion stage, during which a large amount of MG is rapidly adsorbed by the outer surface of the biosorbent. This is considered the fast step, demonstrated by the highest $K_{i d}$ constant values. The second step is the gradual biosorption stage controlled by intraparticle diffusion. As the plots did not cross the origin $(C \neq 0)$, they suggest that intraparticle diffusion is not the only operative mechanism and that the biosorption kinetics of $\mathrm{MG}$ on yeast- $\mathrm{MnO}_{2}$ composites was controlled by both surface and intraparticle diffusion processes.

Table 1. Kinetic parameters estimated by the pseudo first-order, pseudo second-order and intraparticle diffusion models for the $\mathrm{MG}$ biosorption on the yeast- $\mathrm{MnO}_{2}$ composites.

\begin{tabular}{lccc}
\hline Parameters & \multicolumn{3}{c}{ Temperature $\left({ }^{\circ} \mathrm{C}\right)$} \\
\hline & 25 & 35 & 45 \\
$q_{\text {experimental }}\left(\mathrm{mg} \mathrm{g}^{-1}\right)$ & 86.5 & 92.5 & 95.7 \\
Pseudo-first order model & & & \\
$K_{1}\left(\mathrm{~min}^{-1}\right)$ & $4.79 \times 10^{-2}$ & $3.15 \times 10^{-2}$ & $6.79 \times 10^{-2}$ \\
$q_{1}\left(\mathrm{mg} \mathrm{g}^{-1}\right)$ & 62.66 & 41.02 & 30.39 \\
$R^{2}$ & 0.964 & 0.981 & 0.969 \\
Pseudo-second order model & & & \\
$K_{2}\left(\mathrm{~g} \mathrm{mg}^{-1}\right.$ min $\left.^{-1}\right)$ & $1.32 \times 10^{-3}$ & $1.34 \times 10^{-3}$ & $4.75 \times 10^{-3}$ \\
$q_{2}\left(\mathrm{mg} \mathrm{g}^{-1}\right)$ & 92.61 & 98.04 & 98.04 \\
$R^{2}$ & 0.999 & 0.999 & 0.999 \\
Intraparticle diffusion model $_{\text {Step 1 }}$ & & & \\
$K_{\text {id }}\left(\mathrm{mg} \mathrm{g}^{-1} \mathrm{~min}^{-0.5}\right)$ & 5.517 & 7.858 & 5.589 \\
$C\left(\mathrm{mg} \mathrm{g}^{-1}\right)$ & 39.94 & 34.44 & 59.94 \\
$R^{2}$ & 0.973 & 0.986 & 0.941 \\
Step 2 & & & \\
$K_{\text {id }}\left(\mathrm{mg} \mathrm{g}^{-1} \mathrm{~min}^{-0.5}\right)$ & 1.702 & 2.256 & 0.150 \\
$C\left(\mathrm{mg} \mathrm{g}^{-1}\right)$ & 68.53 & 68.33 & 94.13 \\
$R^{2}$ & 0.928 & 0.990 & 0.960 \\
\hline
\end{tabular}

\subsection{Equilibrium isotherm}

The equilibrium biosorption isotherm is a prerequisite to understand how adsorbates interact with adsorbents and how they could be used in the design of sorption systems. In this study, the equilibrium experiments were carried out with different initial dye concentrations (100-350 mg L $\mathrm{L}^{-1}$ ), using $1.0 \mathrm{~g}$ biosorbent $\mathrm{L}^{-1}$ at $25^{\circ} \mathrm{C}$. The most widely used isotherm equations, including the Langmuir, Freundlich, and Dubinin and Radushkevich (D-R) models, were utilized (Chowdhury and Saha, 2010). 

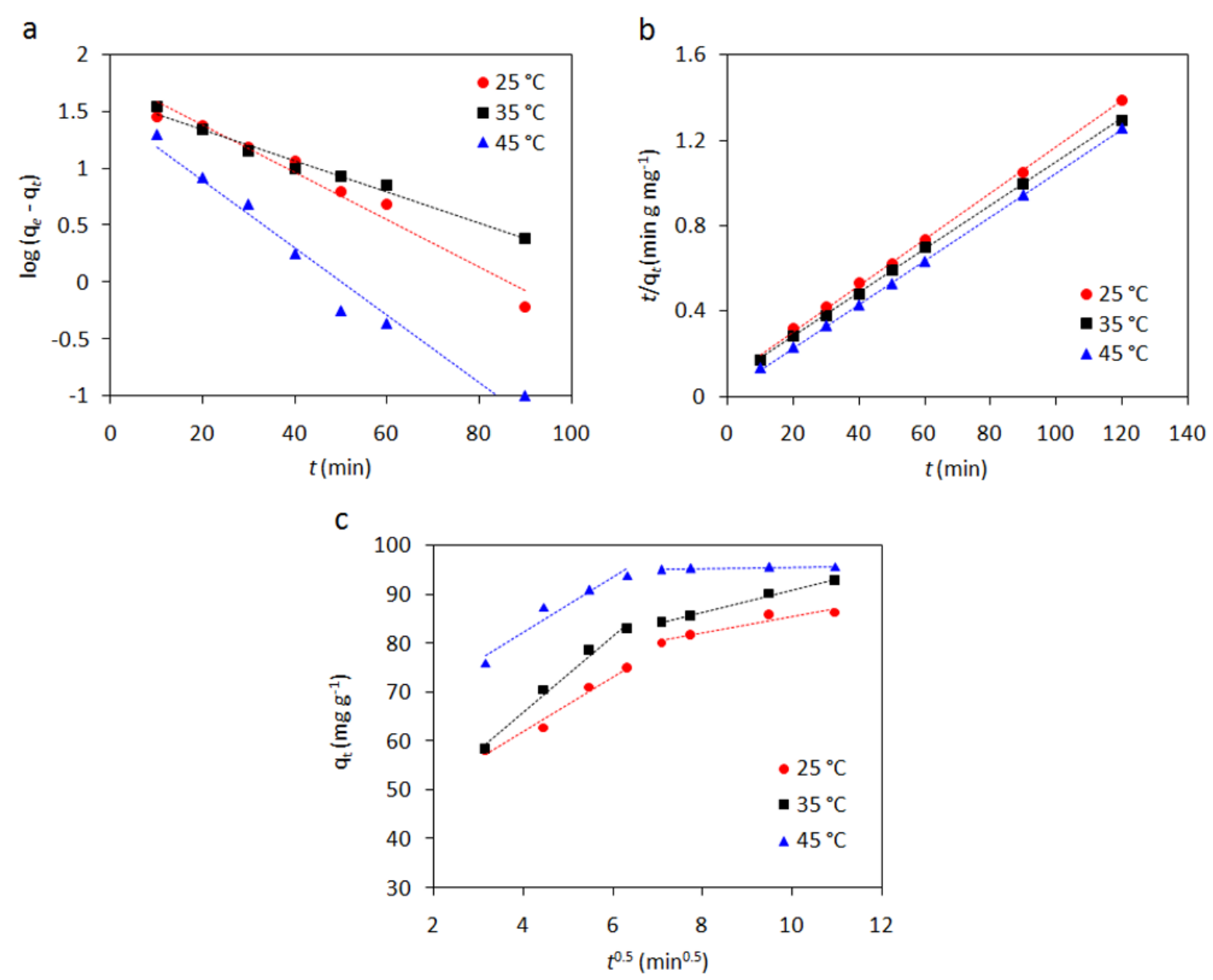

Figure 5. Plots for pseudo-first order (a), pseudo-second order (b) and intraparticle diffusion (c) models for the biosorption of $\mathrm{MG}$ onto yeast- $\mathrm{MnO}_{2}$ composites, at different temperatures.

The Langmuir isotherm model assumes monolayer coverage of adsorbate over a homogeneous adsorbent surface. Also, all the binding sites of the surface have equal energy of sorption. The linear form of the Langmuir equation can be given as in Equation 6:

$\frac{1}{q_{e}}=\frac{1}{q_{\max }}+\left(\frac{1}{q_{\max } K_{L}}\right) \frac{1}{C_{e}}$

where $q_{e}\left(\mathrm{mg} \mathrm{g}^{-1}\right)$ is the amount of dye adsorbed by the biosorbent at the equilibrium, $C_{e}$ $\left(\mathrm{mg} \mathrm{L}^{-1}\right)$ is the dye concentration in the solution at equilibrium, $q_{\max }\left(\mathrm{mg} \mathrm{g}^{-1}\right)$ is the maximum adsorption capacity, and $K_{L}\left(\mathrm{~L} \mathrm{mg}^{-1}\right)$ is the Langmuir constant related to free energy of adsorption. The plot of $1 / q_{e}$ versus $1 / C_{e}$ was employed to generate the values of $q_{\max }$ and $K_{L}$ (Figure 6a).

The Freundlich isotherm, on the order hand, is an empirical equation employed to describe heterogeneous adsorption surface and is given by Equation 7:

$\ln q_{e}=\ln K_{f}+\frac{1}{n} \ln C_{e}$

Where $K_{f}\left(\left(\mathrm{mg} \mathrm{g}^{-1}\right)\left(\mathrm{mg} \mathrm{L}^{-1}\right)^{-1 / n}\right)$ is the Freundlich constant related to the adsorption capacity of adsorbent and $n$ (dimensionless) is intensity of adsorption. $K_{f}$ and $n$ were calculated by plotting $\ln q_{e}$ and $\ln C_{e}$ (Figure 6b).

\section{IPABH}


The D-R model was used to estimate the mean free energy of biosorption. The linearized form of the D-R model is expressed by Equation 8:

$\ln q_{e}=\ln q_{m}-\beta \varepsilon^{2}$

Where $q_{e}\left(\mathrm{~mol} \mathrm{~g}^{-1}\right)$ is the amount of dye adsorbed on the biosorbent, $q_{m}\left(\mathrm{~mol} \mathrm{~g}^{-1}\right)$ is the maximum biosorption capacity, $\beta\left(\mathrm{mol}^{2} \mathrm{~kJ}^{-2}\right)$ is the constant related to the mean free energy of biosorption and $\varepsilon$ is the Polanyi potential. The values of $q_{m}$ and $\beta$ were determined from the linear plot of $\ln q_{e}$ versus $\varepsilon^{2}$ (Figure $6 \mathrm{c}$ ). The $\varepsilon$ value was calculated with Equation 9:

$$
\varepsilon=R T \ln \left(1+\frac{1}{C_{e}}\right)
$$

Where $R\left(8.314 \mathrm{~J} \mathrm{~mol}^{-1} \mathrm{~K}^{-1}\right)$ is the ideal gas constant and $T(\mathrm{~K})$ is the absolute temperature.

Using the activity coefficient $\beta$, it is possible to estimate the mean free energy of biosorption $\left(E, \mathrm{~kJ} \mathrm{~mol}^{-1}\right)$, according to Equation 10 :

$E=\frac{1}{\sqrt{2 \beta}}$

The $E$ value gives information about the mechanism involved in the biosorption. When $E$ value falls in the range from 8 to $16 \mathrm{~kJ} \mathrm{~mol}^{-1}$, the biosorption process is controlled by a chemical mechanism, while for $E<8 \mathrm{~kJ}$ mol, the biosorption process proceeds through a physical mechanism.
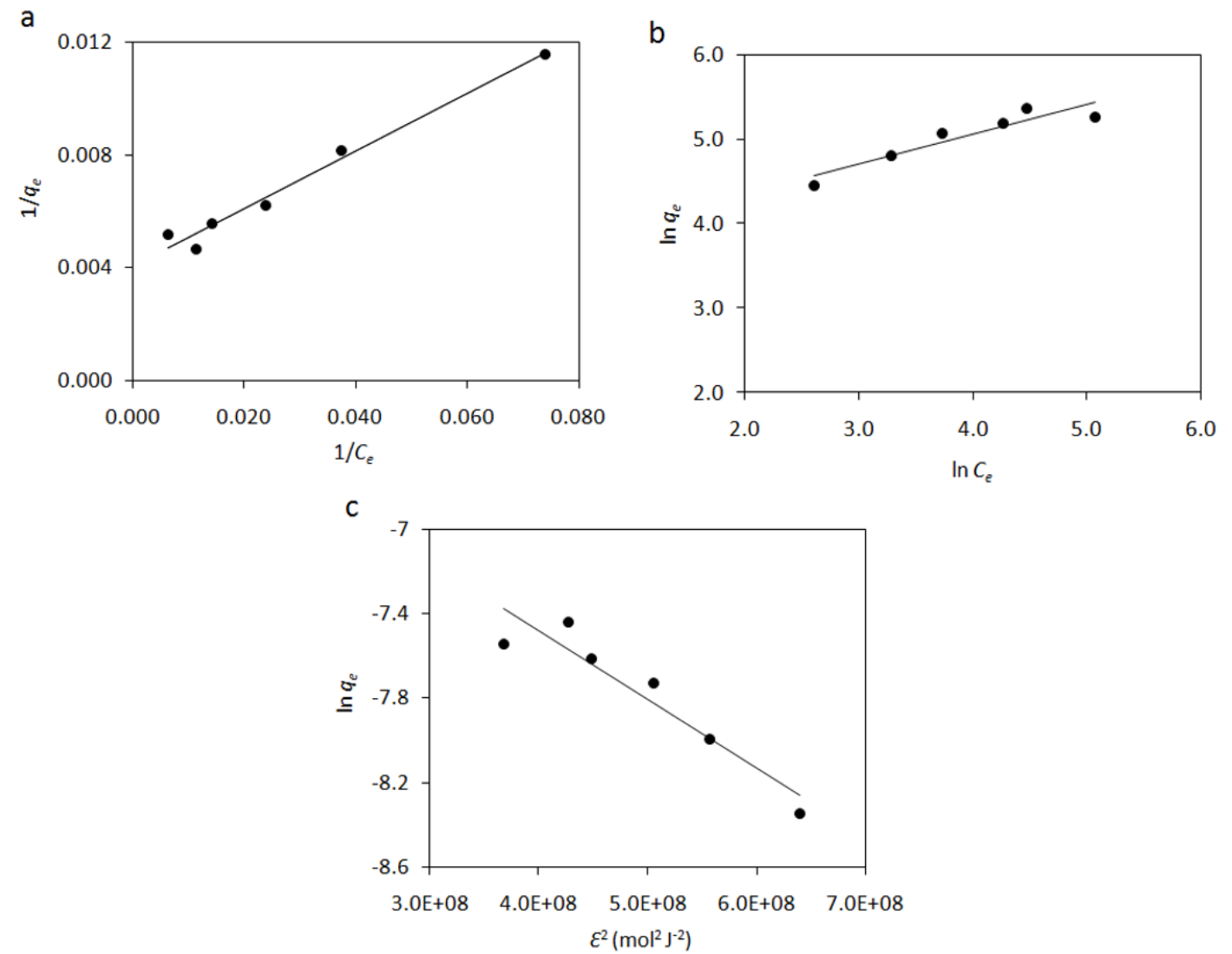

Figure 6. Plots for Langmuir (a), Freundlich (b) and D-R isotherms (c) for the biosorption of $\mathrm{MG}$ onto yeast- $\mathrm{MnO}_{2}$ composites. 
The parameters obtained from the isotherm models applied to the experimental data for MG biosorption onto yeast- $\mathrm{MnO}_{2}$ composites are listed in Table 2. The linear correlation coefficients $\left(R^{2}\right)$ show that the equilibrium data could be better interpreted by the Langmuir isotherm $\left(R^{2}=0.979\right)$ than by the Freundlich isotherm $\left(R^{2}=0.866\right)$. This suggests that the biosorption process of MG onto yeast- $\mathrm{MnO}_{2}$ composites assumes a monolayer adsorption, and the maximum biosorption capacity was $243.90 \mathrm{mg} \mathrm{g}^{-1}$. The maximum adsorption capacities of MG onto various adsorbents reported in the literature are listed in Table 3. The adsorption capacity of yeast- $\mathrm{MnO}_{2}$ composites obtained for $\mathrm{MG}$ in this investigation is higher than those of many corresponding adsorbent materials.

The free energy of MG biosorption was considered via D-R model. A relatively high correlation coefficient $\left(R^{2}=0.890\right)$ was found. As can be seen from Table 2 , the mean biosorption energy $(E)$ calculated was $12.91 \mathrm{~kJ} \mathrm{~mol}^{-1}$, which indicates that the biosorption process of $\mathrm{MG}$ onto yeast- $\mathrm{MnO}_{2}$ composites was considered to be a chemical adsorption.

Table 2. Biosorption isotherm constants for the biosorption of $\mathrm{MG}$ onto yeast- $\mathrm{MnO}_{2}$ composites.

\begin{tabular}{cccccc}
\hline \multicolumn{2}{c}{ Langmuir } & Freundlich & \multicolumn{2}{c}{$D-R$} \\
\hline$q_{\max }\left(\mathrm{mg} \mathrm{g}^{-1}\right)$ & 243.90 & $K_{\mathrm{F}}\left(\mathrm{mg} \mathrm{g}^{-1}\right)\left(\mathrm{mg} \mathrm{L}^{-1}\right)^{-1 / n}$ & 38.18 & $q_{\mathrm{m}}\left(\mathrm{mol} \mathrm{g}^{-1}\right)$ & $2.07 \times 10^{-3}$ \\
$K_{\mathrm{L}}\left(\mathrm{L} \mathrm{mg}^{-1}\right)$ & $4.02 \times 10^{-2}$ & $n$ & 2.819 & $\beta\left(\mathrm{mol}^{2} \mathrm{~J}^{-2}\right)$ & $3.00 \times 10^{-9}$ \\
$R^{2}$ & 0.979 & $R^{2}$ & 0.865 & $E\left(\mathrm{~kJ} \mathrm{~mol}^{-1}\right)$ & 12.91 \\
& & & & $R^{2}$ & 0.890 \\
\hline
\end{tabular}

Table 3. Comparison of MG adsorption capacity of different adsorbents.

\begin{tabular}{lcccc}
\hline Adsorbent & $\mathrm{T}\left({ }^{\circ} \mathrm{C}\right)$ & $\mathrm{pH}$ & $q_{\max }\left(\mathrm{mg} \mathrm{g}^{-1}\right)$ & Reference \\
\hline Brown-rotted pine wood & 30 & 4.0 & 29.85 & Zhang et al. (2011) \\
Leaf of pineapple (Ananas comosus) & 25 & 9.0 & 54.64 & Chowdhury et al. (2011) \\
Potato peel & 25 & 4.0 & 32.39 & Guechi and Hamdaoui (2016) \\
Sea shell powder & 30 & 8.0 & 42.33 & Chowdhury and Saha (2010) \\
Rice straw modified with citric acid & 20 & 6.0 & 256.41 & Gong et al. (2006) \\
Degreased coffee bean & 25 & 4.0 & 55.30 & Baek et al. (2010) \\
Baker's yeast- $\mathrm{MnO}_{2}$ composites & 25 & 10 & 243.90 & Present study \\
\hline
\end{tabular}

\subsection{Thermodynamic study}

To investigate the thermodynamics of $\mathrm{MG}$ biosorption onto yeast- $\mathrm{MnO}_{2}$ composites, the main thermodynamic parameters, such as standard changes of free energy $\left(\Delta G^{\circ}\right)$, enthalpy $\left(\Delta H^{\circ}\right)$ and entropy $\left(\Delta S^{\circ}\right)$ were calculated by the following Equations 11,12 and 13:

$$
\begin{aligned}
& \Delta G^{\circ}=-R T \ln K_{D} \\
& \Delta G^{\circ}=\Delta H^{\circ}-T \Delta S^{\circ}
\end{aligned}
$$

The combination of Equations 11 and 12 gives:

$$
\ln K_{D}=\frac{\Delta S^{\circ}}{R}-\frac{\Delta H^{\circ}}{R} \times \frac{1}{T}
$$

Where $K_{D}\left(q_{e} / C_{e}\right)$ is the distribution coefficient, $T(\mathrm{~K})$ is the absolute temperature and $R$ is the universal gas constant $\left(8.314 \mathrm{~J} \mathrm{~K}^{-1} \mathrm{~mol}^{-1}\right)$. The values of $\Delta H^{\circ}$ and $\Delta S^{\circ}$ were determined from the plot of $\ln K_{D}$ against $1 / T$ (Figure 7 ).

\section{IPABH}

Rev. Ambient. Água vol. 14 n. 1, e2254 - Taubaté 2019 


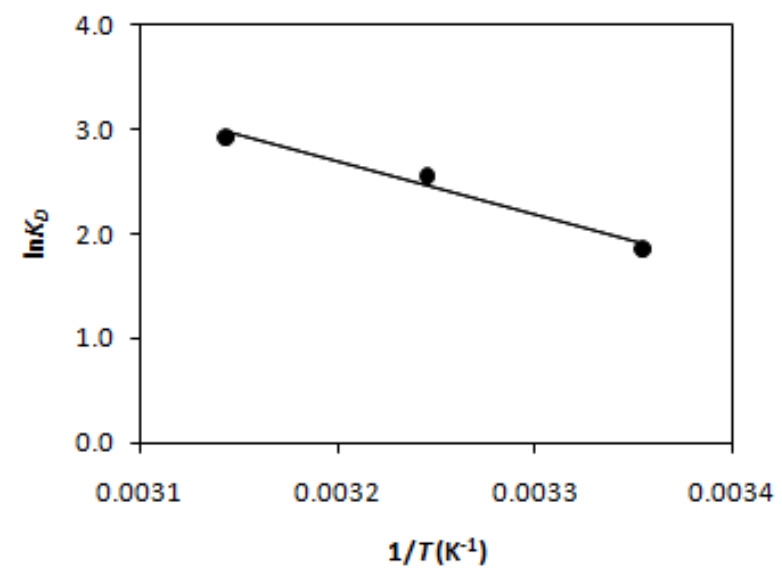

Figure 7. Plot of $\ln K_{D}$ versus $1 / T$ for estimation of thermodynamic parameters.

The calculated thermodynamic parameters are listed in Table 4. The negative values of $\Delta G^{\circ}$ indicate that the $\mathrm{MG}$ biosorption onto yeast- $\mathrm{MnO}_{2}$ composites is spontaneous and feasible at all the studied temperatures $\left(25,35\right.$ and $\left.45^{\circ} \mathrm{C}\right)$. The change in the standard enthalpy $\left(\Delta H^{\circ}\right)$ was $42.1 \mathrm{~kJ} \mathrm{~mol}^{-1}$. The positive value of $\Delta H^{\circ}$ suggests that the biosorption is endothermic in nature and reflects the affinity of yeast- $\mathrm{MnO}_{2}$ composites for MG. This trend may be explained by the availability of more active sites of biosorbent at higher temperatures due to increased surface activity and increased kinetic energy of the MG molecules (Akar et al., 2009). The $\Delta S^{\circ}$ parameter was also found to be positive, thus suggesting that the randomness at the biosorbent/solution interface increases during the biosorption of dye.

Table 4. Thermodynamic parameters estimated for MG biosorption onto yeast- $\mathrm{MnO}_{2}$ composites.

\begin{tabular}{ccccc}
\hline $\mathrm{T}\left({ }^{\circ} \mathrm{C}\right)$ & $K_{\mathrm{D}}$ & $\Delta G^{\circ}\left(\mathrm{kJ} \mathrm{mol}^{-1}\right)$ & $\Delta H^{\circ}\left(\mathrm{kJ} \mathrm{mol}^{-1}\right)$ & $\Delta S^{\circ}\left(\mathrm{J} \mathrm{mol}^{-1} \mathrm{~K}^{-1}\right)$ \\
\hline 25 & 6.39 & -4.70 & 42.10 & 157.0 \\
35 & 12.76 & -6.27 & & \\
45 & 18.53 & -7.84 & & \\
\hline
\end{tabular}

\subsection{FTIR analysis}

FTIR spectroscopy is an important technique to identify the functional groups in the surface of adsorbents and the possible interactions between them and the adsorbate. As seen in the spectrum of yeast- $\mathrm{MnO}_{2}$ composites before $\mathrm{MG}$ adsorption (Figure 8a), a broad and strong band at around $3425.58 \mathrm{~cm}^{-1}$ is indicative of the overlapping of $\mathrm{O}-\mathrm{H}$ and $\mathrm{N}-\mathrm{H}$ stretching vibrations (Yang et al., 2011). The peaks at 2924.09 and $2854.65 \mathrm{~cm}^{-1}$ are attributed to the $\mathrm{C}-$ $\mathrm{H}$ stretching vibrations of aliphatic groups (Yang et al. 2011). Protein-related bonds of amide I, II and III are observed at peaks $1651.07,1543.05$ and $1242.16 \mathrm{~cm}^{-1}$, respectively, while the band at $1404.18 \mathrm{~cm}^{-1}$ is attributed to $\mathrm{C}-\mathrm{OH}$ bend from carboxylic groups (Xia et al., 2015). The band at $1041.56 \mathrm{~cm}^{-1}$ can be due to stretching of glycitols $(\mathrm{C}-\mathrm{OH})$, the $\mathrm{P}-\mathrm{O}-\mathrm{C}$ (Zhang et al., 2011) and $\mathrm{C}-\mathrm{OH}$ dimer carboxylic acid. The peak observed at the low-frequency region around $470.63 \mathrm{~cm}^{-1}$ is ascribed to $\mathrm{Mn}-\mathrm{O}$ vibrations (Parikh and Chorover, 2005), indicating the presence of nano- $\mathrm{MnO}_{2}$ particles on the yeast surface (Xia et al., 2015). After MG adsorption (Figure $8 \mathrm{~b}$ ), the peak at $470.63 \mathrm{~cm}^{-1}$ disappeared and the presence of a new peak at $578.64 \mathrm{~cm}^{-1}$ indicated that the nano- $\mathrm{MnO}_{2}$ particles on yeast- $\mathrm{MnO}_{2}$ composite surface were responsible for MG biosorption. Additionally, the peak at $3425.58 \mathrm{~cm}^{-1}$ shifted to 3410.15 , indicating that those functional groups might contribute to MG biosorption. 
A

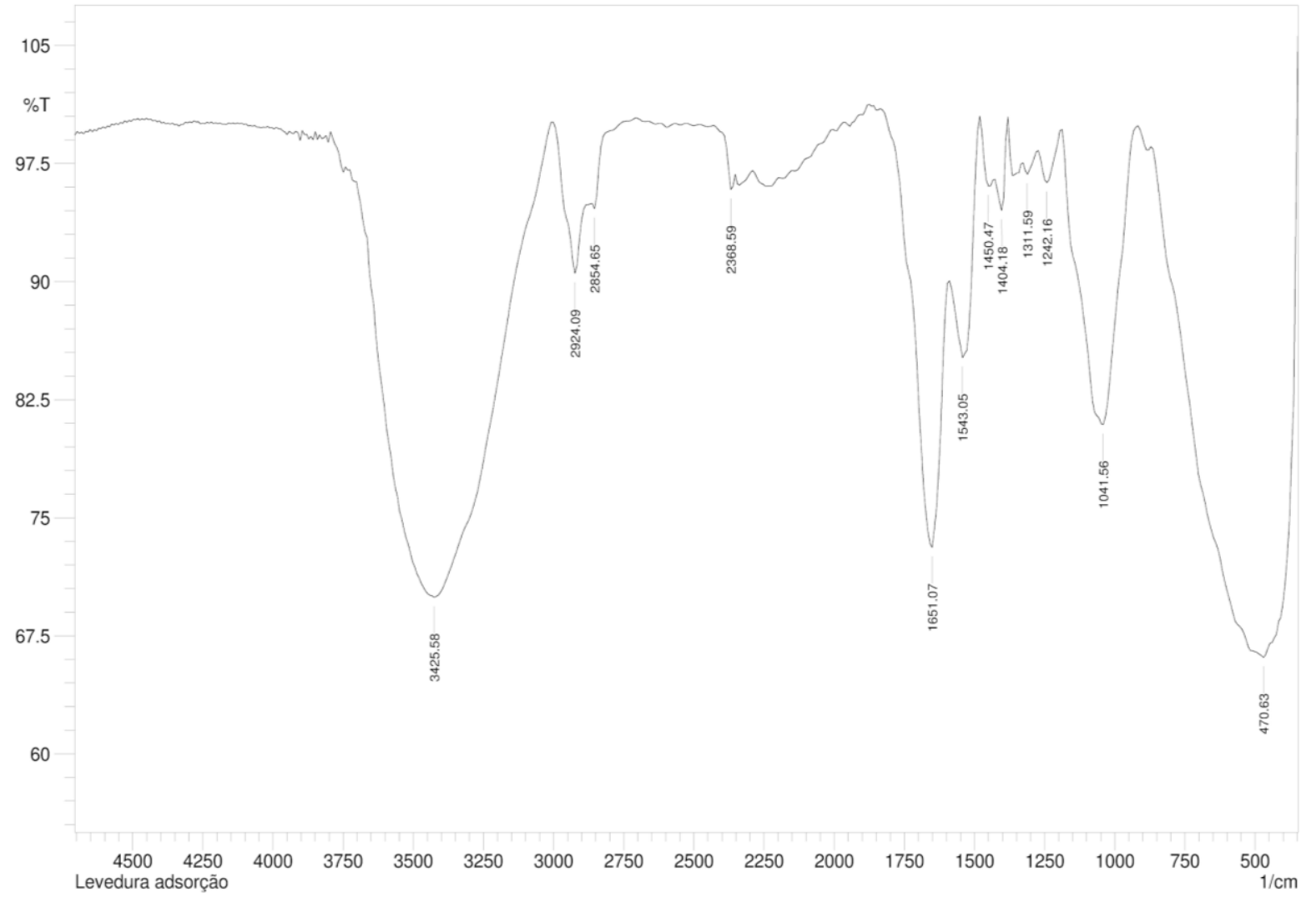

B

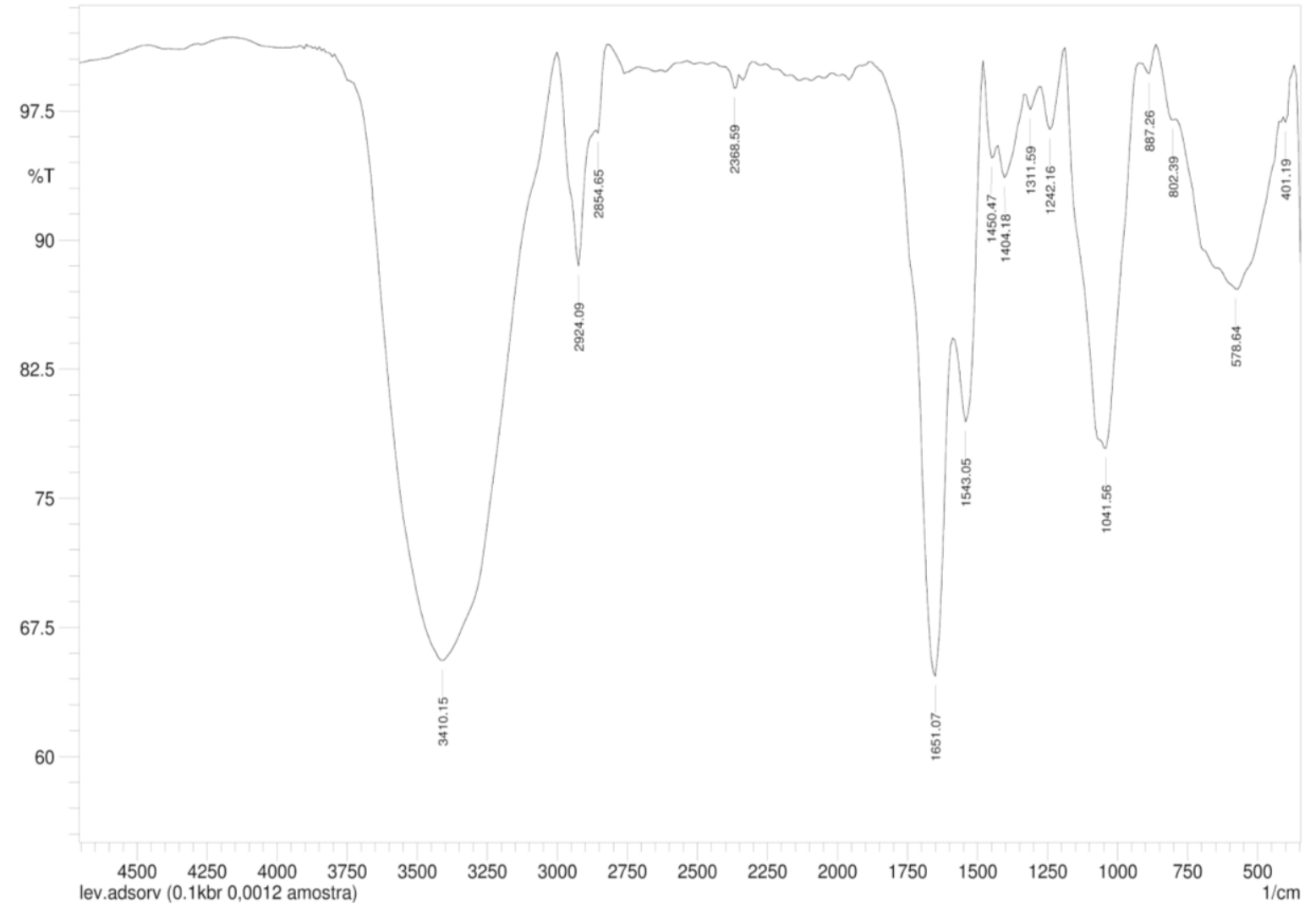

Figure 8. FTIR spectra of yeast-MnO 2 composites before MG adsorption (a) and after MG adsorption (b). 


\section{CONCLUSION}

Modification of baker's yeast with $\mathrm{KMnO}_{4}$ under acidic conditions significantly increased the biosorption capacity of MG compared to unmodified yeast. The biosorption process proved to be dependent on the $\mathrm{pH}$ of the solution, temperature, contact time, biosorbent dosage and initial concentration of dyes. The optimum removal of $\mathrm{MG}$ was found to be $86.7 \mathrm{mg} \mathrm{g}^{-1}$ at $\mathrm{pH}$ $10,1.0 \mathrm{~g} \mathrm{~L}^{-1}$ of biomass dosage and $45^{\circ} \mathrm{C}$. The experimental data fit well with pseudo-secondorder model and Langmuir models, and the maximum biosorption capacity was estimated to be $243.9 \mathrm{mg} \mathrm{g}^{-1}$ (at $25^{\circ} \mathrm{C}$ ). Thermodynamic parameters, $\Delta G^{\circ}$ and $\Delta H^{\circ}$, indicated that the MG biosorption onto yeast- $\mathrm{MnO}_{2}$ composites is spontaneous and endothermic. In conclusion, yeast$\mathrm{MnO}_{2}$ composites may be an economic, effective and eco-friendly option for the removal of the cationic dye MG from aqueous media.

\section{ACKNOWLEDGMENTS}

This work was supported by CNPq under Grant 486168/2013-1.

\section{REFERENCES}

AKAR, S. T.; YILMAZER, D.; CELIK, S.; BALK, Y. Y.; AKAR, T. Effective bio decolorization potential of surface modified lignocellulosic industrial waste biomass. $\begin{array}{lllllll}\text { Chemical Engineering Journal, v. 259, p. 286-292, } 2015 . & \text {. }\end{array}$ http://dx.doi.org/10.1016/j.cej.2014.07.112

AKAR, T.; TOSUN, I.; KAYNAK, Z.; OZKARA, E.; YENI, O.; SAHIN, E. N.; TUNALI, S. An attractive agro-industrial by-product in environmental cleanup: Dye biosorption potential of untreated olive pomace. Journal of Hazardous Materials, v. 166, p. $1217-$ 1225, 2009. https://doi.org/10.1016/j.jhazmat.2008.12.029

BAEK, M. H.; IJAGBEMI, C. O.; O, S. J.; KIM, D. S. Removal of Malachite Green from aqueous solution using degreased coffee bean. Journal of Hazardous Materials, v. 176, n. 1-3, p. 820-828, 2010. https://doi.org/10.1016/j.jhazmat.2009.11.110

CASTRO, K. C.; COSSOLIN, A. S.; REIS, H. C. O.; MORAIS, E. B. Biosorption of anionic textile dyes from aqueous solution by yeast slurry from brewery. Brazilian Archives of Biology and Technology, v. 60, p. 1-13, 2017. https://doi.org/10.1590/1678-43242017160101

CHEN, Z.; DENG, H.; CHEN, C.; YANG, Y.; XU, H. Biosorption of malachite green from aqueous solutions by Pleurotus ostreatus using Taguchi method. Journal of Environmental Health Science and Engineering, v. 12, n. 1, p. 63, 2014. http://dx.doi.org/jehse.biomedcentral.com/articles/10.1186/2052-336X-12-63

CHOWDHURY, S.; CHAKRABORTY, S.; SAHA, P. Biosorption of Basic Green 4 from aqueous solution by Ananas comosus (pineapple) leaf powder. Colloids and Surfaces B: $\begin{array}{lllllll}\text { Biointerfaces, } & \text { v. } \quad 84, \quad \text { n. } & 2, & \text { p. } & 520-527,\end{array}$ http://dx.doi.org/10.1016/j.colsurfb.2011.02.009

CHOWDHURY, S.; SAHA, P. Sea shell powder as a new adsorbent to remove Basic Green 4 (Malachite Green) from aqueous solutions: Equilibrium, kinetic and thermodynamic studies. Chemical Engineering Journal, v. 164, n. 1, p. 168-177, 2010. http://dx.doi.org/10.1016/j.cej.2010.08.050 
FAN, H.; YANG, J.; GAO, T.; YUAN, H. Removal of a low-molecular basic dye (Azure Blue) from aqueous solutions by a native biomass of a newly isolated Cladosporium sp.: Kinetics, equilibrium and biosorption simulation. Journal of the Taiwan Institute of

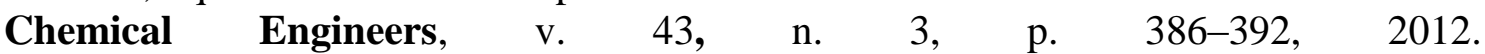
http://dx.doi.org/10.1016/j.jtice.2011.11.001

GONG, R.; JIN, Y.; CHEN, F.; CHEN, J.; LIU, Z. Enhanced malachite green removal from aqueous solution by citric acid modified rice straw. Journal of Hazardous Materials, v. 137, n. 2, p. 865-870, 2006. https://doi.org/10.1016/j.jhazmat.2006.03.010

GUECHI, E. K.; HAMDAOUI, O. Sorption of malachite green from aqueous solution by potato peel: Kinetics and equilibrium modeling using non-linear analysis method. Arabian Journal of Chemistry, v. 9, p. S416-S424, 2016. https://doi.org/10.1016/j.arabjc.2011.05.011

KEDARI, C. S.; DAS, S. K.; GHOSH, S. Biosorption of long lived radionuclides using immobilized cells of Saccharomyces cerevisiae. World Journal of Microbiology and Biotechnology, v. 17, p. 789-793, 2001. https://dx.doi.org/10.1023/A:1013547307770

KHATAEE, A. R.; VAFAEI, F.; JANNATKHAH, M. Biosorption of three textile dyes from contaminated water by filamentous green algal Spirogyra sp.: Kinetic, isotherm and thermodynamic studies. International Biodeterioration and Biodegradation, v. 83, p. 33-40, 2013. http://dx.doi.org/10.1016/j.ibiod.2013.04.004

PARIKH, S. J.; CHOROVER, J. FTIR spectroscopic study of biogenic Mn-Oxide formation by Pseudomonas putida GB-1. Geomicrobiology Journal, v. 22, p. 207-218, 2005. https://doi.org/10.1080/01490450590947724

WU, Y.; HU, Y.; XIE, Z.; FENG, S.; LI, B.; MI, X. Characterization of biosorption process of acid orange 7 on waste brewery's yeast. Applied Biochemistry and Biotechnology, v. 163, n. 7, p. 882-894, 2011. https://doi.org/10.1007/s12010-010-9092-z

XIA, Y.; MENG, L.; JIANG, Y.; ZHANG, Y.; DAI, X.; ZHAO, M. Facile preparation of $\mathrm{MnO}_{2}$ functionalized baker's yeast composites and their adsorption mechanism for Cadmium. $\begin{array}{lllllll}\text { Chemical Engineering Journal, v. 259, p. 927-935, } 2015 . & \end{array}$ http://dx.doi.org/10.1016/j.cej.2014.08.071

YANG, Y.; JIN, D.; WANG, G.; LIU, D.; JIA, X.; ZHAO, Y. Biosorption of Acid Blue 25 by unmodified and CPC-modified biomass of Penicillium YW01: Kinetic study, equilibrium isotherm and FTIR analysis. Colloids and Surfaces B: Biointerfaces, v. 88, n. 1, p. 521526, 2011. http://dx.doi.org/10.1016/j.colsurfb.2011.07.047

YU, J. X.; LI, B. H.; SUN, X. M.; YUAN, J.; CHI, R. Polymer modified biomass of baker's yeast for enhancement adsorption of methylene blue, rhodamine $\mathrm{B}$ and basic magenta. Journal of Hazardous Materials, v. 168, n. 2-3, p. 1147-1154, 2009. https://doi.org/10.1016/j.jhazmat.2009.02.144

ZHANG, H.; TANG, Y.; LIU, X.; KE, Z.; SU, X.; CAI, D. et al. Improved adsorptive capacity of pine wood decayed by fungi Poria cocos for removal of Malachite green from aqueous solutions. Desalination, v. 274, n. 1-3, p. 97-104, 2011. https://doi.org/10.1016/j.desal.2011.01.077 


Ambiente \& Água - An Interdisciplinary Journal of Applied Science
ISSN 1980-993X - doi:10.4136/1980-993X
www.ambi-agua.net
E-mail: ambi.agua@gmail.com

\title{
Wastewater treatment using adsorption process in column for agricultural purposes
}

\author{
ARTICLES doi:10.4136/ambi-agua.2178
}

Received: 03 Sep. 2017; Accepted: 01 Dec. 2018

\author{
Flávia Rhuana Pereira Sales ${ }^{1 *}$; ; Reynaldo Borges Galvão Serra ${ }^{1}$; \\ Gesivaldo Jesus Alves de Figueirêdo ${ }^{1}$; ; Paulo Henrique Almeida da Hora ${ }^{2}{ }^{\circledR}$; \\ Antonio Cícero de Sousa ${ }^{1}$ (iD \\ ${ }^{1}$ Instituto Federal de Educação, Ciência e Tecnologia da Paraíba (IFPB), João Pessoa, PB, Brasil \\ Departamento de Química. E-mail: flavia.rhuana@outlook.com, reynaldoifpb@hotmail.com, \\ gesivaldo.figueiredo@ifpb.edu.br, antonio.cicero@ifpb.edu.br \\ ${ }^{2}$ Universidade Federal da Paraíba (UFPB), João Pessoa, PB, Brasil \\ Programa de Pós-Graduação em Ciência e Engenharia de Materiais (PPCEM). \\ E-mail: pauloalmeidaeng@gmail.com \\ *Corresponding author
}

\begin{abstract}
Water is essential for life, important for the ecosystem and it is in great demand due to its scarcity. This study explored the reuse of the wastewater of the Water Treatment Plant in Gramame for agricultural purposes. A qualitative and quantitative investigation of the effluent was carried out through the characterization of its physical and chemical parameters, comparing the results to what is allowed by the current legislation, CONAMA Resolution 357/2005. After this process, the activated charcoal of coco-da-baia mesocarp, adsorbent material, was prepared and tested in a filter system in a column with a continuous flow and ascendant entrance, in which the kinetic effect was evaluated. This technique was evaluated by correlating the reduced values in the adsorption material, respecting the initial effluent concentration, obtaining a reduction of $50 \%$ in the hardness, $87.5 \%$ in chloride and $66.6 \%$ in acidity. These results verified the adequacy of the technique in potential hydrogenation $(\mathrm{pH})$ and abrupt reduction of color and turbidity. This treatment is suggested to qualify the effluent for use in agricultural, safe for humans and the environment. The adsorbent substrate efficiency was verified by correlating it with the Thomas isothermal model.
\end{abstract}

Keywords: activated charcoal of the coco-da-baia mesocarp, adsorption process, reuse of water.

\section{Tratamento de águas residuárias utilizando processo de adsorção em coluna para fins agrícolas}

\section{RESUMO}

A água é um recurso essencial para vida, de extrema relevância para o ecossistema e encontra-se com várias problemáticas, entre elas a escassez. Por conta disso, o presente estudo foi desenvolvido a fim de propiciar a reutilização da água residuária da Estação de Tratamento de Água de Gramame para fins agrícolas. Assim, foi realizada a investigação qualitativa e quantitativa deste efluente, por meio da caracterização deste, considerando os parâmetros físicos e químicos, em que os resultados obtidos foram comparados com a legislação vigente, 
resolução CONAMA n ${ }^{\circ}$ 357/2005. Após este processo, o carvão ativado do mesocarpo do cocoda-baía, material adsorvente, foi preparado e testado em um sistema de filtração em coluna com fluxo contínuo e entrada ascendente, na qual, o efeito da cinética foi avaliado. Com isso a técnica foi avaliada correlacionando os valores reduzidos na adsorção em relação a concentração inicial do efluente, obtendo redução de 50\% na dureza, 87,5\% em cloretos e $66,6 \%$ na acidez, estes resultados contribuíram na adequação do potencial hidrogeniônico $(\mathrm{pH})$, redução abrupta de cor e turbidez. Com isso, vislumbra-se ofertar esta técnica de tratamento para qualificação do efluente no âmbito agrícola com segurança e adequação para o homem e o meio ambiente. A eficiência do substrato adsorvente, foi verificada correlacionando-a com o modelo isotérmico de Thomas.

Palavras-chave: processo de adsorção, qualidade de água, substrato adsorvente.

\section{INTRODUCTION}

Water is a natural resource that is crucial for the survival and equilibrium of the ecosystem. It is used in many fields and for many purposes. With the passage of time, this resource has become progressively more scarce in urban, industrial and agricultural development, mainly in arid and semiarid regions.

Not only these regions suffer from water scarcity, however. Some regions have abundant water resources but in insufficient quantity to satisfy the excessive demand, which leads to restrictions on consumption. Thus, administrative agencies of water resources and the academic community are searching for new sources of water supply as well as technology that permits water waste reduction. This includes making users aware of water issues, rationalizing water use, and increasing the available water for agricultural use.

According to Telles and Costa (2010, p. 155), water reuse is "considered an intelligent option for the world market, where the need of this technology application... is in the very concept of sustainability of environmental resources". Moreover, there are plenty of water bodies appropriate for reuse, whether contaminated, polluted or clean.

Water can be contaminated by a large variety of substances, to include chemical, physical/biological agents. An example of this is the wastewater from Water Treatment Plants (WTPs). A WTP applies processes to raw water, resulting in a final product (treated water). Raw water is treated with different chemical reagents, which produce residue. According to Achon et al. (2008, p. 54), "the residues produced from WTPs are mainly the water from filter cleaning and sludge".

Wastewater from the process mentioned before are the water from the cleaning, filters, settling tanks, and solution preparation tanks. For this water to be reused in the agricultural sector, it is necessary to check the physical, chemical and bacteriological conditions, patterns and requirements established by the Resolution of the National Counseling of the Environment (CONAMA) in number 357 (CONAMA, 2005).

There are several processes available for water treatment. Most of them are economically unviable, such as: oxidation, reverse osmosis, ion exchange, electrodialysis, electrolysis. These processes can cost from US\$ 10 to US\$ 450 per cubic meter of treated water. The use of adsorption technology, however, lowers this cost to US\$ 5.0 to US\$200 per cubic meter of water (Ali et al., 2012). The adsorption technique is defined as a process of transference of mass where one or more substances (adsorbate) present in a gaseous or liquid stream is transferred in a selective way to the surface of a porous solid (adsorbent).

The adsorption technique is widely used in the treatment of water, being a technologically and economically viable technology, able to remove organic pollutants with efficiency of $99.9 \%$ (Ali et al., 2012). 
From this perspective, the column adsorption process can be used because it is determined by a dynamic process that involves liquid flow and mass transference from an ionic exchange. The application of the adsorptive process in a column has been studied in several matrices (Ali, 2010; De Franco et al., 2018; Do Nascimento et al., 2014; Yaumi et al., 2018; Matsubara and Coelho, 2018; Monteiro, 2017). In addition, an adsorptive column allows a more efficient use of the adsorbent, since the dynamic system enables an evaluation of the material saturation in relation to the time, space and length of the adsorption column (Sousa Neto, 2012).

A popular means of evaluating an adsorbent in a column system, according to Yang et al. (2015), is Thomas's model. Yang notes that "traditionally this model is used to determine the maximum capacity of adsorption of an adsorbent in a continuous system".

In this perspective, the adsorbent often used is activated carbon because it has the appropriate porous inner surfaces for the access of gas/liquid. Along the same line, Silva et al. (2015, p. 654) explained that "the charcoal prepared from the coconut shell and thermally activated presents excellent capacity for adsorption as adsorbent due to the presence of basic functional groups, such as carboxylics, hydroxyls and lactones". Also,coal has been used for the treatment of effluents since 1940 as one of the main adsorbents due to its great adsorption capacity (Ali, 2010).

Finally, research must be accompanied by alternative technologies directed towards wastewater reuse. An adsorption process in column and continuous flow with the activated carbon of Coco-da-baia Mesocarp (Cocos nucífera L.) was evaluated for the purpose of treating wastewater from a WTP located in João Pessoa-PB, according to the conditions stated by the Resolution of CONAMA, number 357. The treated water was then used for agricultural processes, competing a sustainable action.

\section{MATERIALS AND METHODS}

Selection of the study area was made by visiting the Water Treatment Plant in Gramame located in João Pessoa - PB, which is responsible for most of the public water provision of João Pessoa. The WTP had not previously used the treatment process to take advantage of its effluent.

The methodology used to analyze the data was quantitative, that "emphasizes numbers (or information convertible into numbers) to verify the existence or not of the consequences ... The data are analyzed with Statistics support (including multivariate) or other mathematical techniques" (Dalfovo et al., 2008, p. 7).

First, wastewater samples were collected with the purpose of describing them according to the Resolution Number 357 of CONAMA, through an adsorption process in column with continuous flow in order to be used in the agricultural fields.

The physical-chemical analyses that were made were: physical parameters (temperature; color; smell) and chemical (turbidity, hydrogenionic potential - $\mathrm{pH}$; carbonic acidity and total; calcium hardness, magnesia and total; conductivity; alkalinity; chlorides).

All the processes of preparation and analyses of the contemplated parameters of the research conformed to what is described in "Standard Methods for the Examination of Water and Wastewater" (APHA, 2005).

The preparation of the charcoal substrate was made as follows: washing of the raw material (coco-da-baia mesocarp) and then exposing it to the sun. The contact surface of the material was then prepared using a hammer, to crush, sieve and char the husk/shell in a rotating electric oven with a fixed recipient reactor. The material was reduced to fibers in a grinder and exposed to high temperatures in order to increase the porosity and efficiency of the mesocarp. After this step, the charcoal of the mesocarp was obtained through a process of activation with phosphoric acid.

\section{IPABH}

Rev. Ambient. Água vol. 14 n. 1, e2178 - Taubaté 2018 
In the chemical activation process, the fibers were immersed for two hours in phosphoric acid at a ratio of $90 \%\left(\mathrm{H}_{3} \mathrm{PO}_{4}\right.$ mass / fiber mass). The fibers were then placed in a rotary electric oven (CHINO) at a temperature of $1173 \mathrm{~K}\left(900^{\circ} \mathrm{C}\right)$ for five hours for carbonization. In the final stage, the charcoal was washed various times with distilled water at $100^{\circ} \mathrm{C}$ to remove the excess reagent used in the chemical activation until the $\mathrm{pH}$ of the water had reached around 7.0 (Cambuim, 2009). Finally, the charcoal was dried (in an oven at $110^{\circ} \mathrm{C}$ ) for 24 hours, macerated and sieved in a 200 mesh.

Afterwards, investigation began of the capacity of the coco-da-baia mesocarp's activated charcoal's adsorption in a column with continuous flow weighing 0.5 grams. The column was made of a glass recipient, $5 \mathrm{~cm}$ in diameter, containing sand, gravel, grit and the substrate, organized respectively in an initial layer of gravel, grit, thick sand, thin sand, activated carbon, thin sand and thick sand. It is important to highlight that all this material had been washed with hydrochloric acid $(\mathrm{HCl})$ at $10 \%$.

For the adsorption process, about 50 liters of the wastewater sample was poured through the adsorbent of the continuous flow column with an ascending entrance, for 7 hours at a flow of 1.5 L/hr. Eight samples were collected at 30, 60, 120, 180, 240, 300, 360 and 420 minutes.

After the collection, the samples were submitted to physical-chemical analyses (temperature; color; smell, turbidity, hydrogen ionization potential - $\mathrm{pH}$; carbonic acidity and total; calcium hardness, magnesia and total; conductivity; alkalinity; chlorides) with the objective of verifying the quantity each element that had been adsorbed.

When this was finished, the results were organized in a chart to make graphics, in order to better observe the adsorption behavior after each specific contact time. The results were then adjusted to the isotherm adsorption model established by Thomas to prove and set the maximum capacity of the adsorbent adsorption studied.

\section{RESULTS AND DISCUSSION}

Human activities promote high levels of pollution, according to the National Inventory of Water Quality generated by the U.S Environmental Protection Agency, which reported that $45 \%$ of the rivers, $47 \%$ of the lakes and $32 \%$ of the estuaries in the US. are already polluted. Similarly, in Brazil, the water captured by the WTP's comes from rivers, making chemical treatment essential and creating effluents. As most of the effluents are thrown away without treatment, our aim was to use them for agriculture through an adsorption treatment with charcoal made from Coco-da-baia mesocarp.

The effluent, water from cleaning filters of the WTP in Gramame was collected and described. High quantities of turbidity and color were found, which had been expected due to the presence of organic matter and particles in suspension. In relation to the total hardness present in the effluent, the wastewater tested at $32 \mathrm{mg} \mathrm{L}^{-1}$, alkalinity of $12 \mathrm{mg} \mathrm{L}^{-1}$, the chloride parameters were quantified at $39 \mathrm{mg} \mathrm{L}^{-1}$ and the $\mathrm{pH}$ was 5.38. Considering acidity, it is known that when the amount of the carbonic acid is the same as the total acid, then the total acid is considered as carbonic. This, however, was not noticed in our results. Thus, it is possible to conclude that there was a presence of minerals, because the analyses proposed for the total acidity corresponded to the quantity of $\mathrm{CO}_{2}$ present in the water, just like minerals. Besides that, the $\mathrm{pH}$ was below the maximum value allowed by the decree of CONAMA, Resolution 357.

To sum up, only the turbidity parameters, $\mathrm{pH}$ and color were different from the standards established by Resolution Number 357 of CONAMA for agricultural purposes. Therefore, the efficiency of the substrate, charcoal of the mesocarp, was studied in relation to the abovementioned standards, so as to verify its capacity to transform the water for reuse.

With this quantification done, the preparation of the substrate for the adsorption process 
was carried out. With the charcoal of the coconut mesocarp, the adsorption of the continuous flow column tests began. Table 1 illustrates the results.

Table 1. Results of Post Adsorption Parameters.

\begin{tabular}{|c|c|c|c|c|c|c|c|c|c|}
\hline Adsorption Time (min) & $\mathbf{0}$ & 30 & 60 & 120 & 180 & 240 & 300 & 360 & 420 \\
\hline Conductivity $\mu \mathrm{S} / \mathrm{cm}^{2}$ & 123.0 & 163.8 & 119 & 57.9 & 56.8 & 125.4 & 93.3 & 105.1 & 101.5 \\
\hline pH & 5.38 & 6.94 & 6.98 & 6.89 & 6.84 & 7.08 & 7.00 & 6.84 & 7.10 \\
\hline Turbidity NTU & 184 & 59 & 41 & 31 & 52 & 61 & 87 & 89 & 91 \\
\hline Alkalinity $\mathrm{mg} \mathrm{L}^{-1}$ & 12 & 10 & 10 & 10 & 10 & 10 & 10 & 12 & 12 \\
\hline Total Acidity mg L ${ }^{-1}$ & 30 & 20 & 20 & 10 & 10 & 10 & 10 & 10 & 10 \\
\hline Chlorides $\mathrm{mg} \mathrm{L}^{-1}$ & 39.99 & 39.99 & 24.99 & 19.99 & 19.99 & 15.00 & 10.00 & 5.00 & 10.00 \\
\hline Total Hardness mg L $^{-1}$ & 32 & 24 & 16 & 16 & 16 & 16 & 16 & 16 & 16 \\
\hline Calcium Hardness mg L $^{-1}$ & 8 & 6 & 2 & 2 & 4 & 4 & 4 & 2 & 4 \\
\hline Magnesia Hardness $\mathrm{mg} \mathrm{L}^{-1}$ & 24 & 18 & 14 & 14 & 12 & 12 & 12 & 14 & 12 \\
\hline
\end{tabular}

These results showed that the adsorbent material was able to reduce the concentration of all parameters in the study. Time 0 refers to the raw sample and the others correspond to the amount of each in the sample collections, making it possible to evaluate the data in relation to the time of contact. As most of the parameters were within the standards, the study was based on those that had decreased more than $50 \%$ in the adsorption process.

The hardness parameter, represented by the degree of water salinity, was reduced by $50 \%$. This decrease makes the water reusable for in agriculture, because it avoids the excess of salts that cause the leaching process (dissolved salts in the ground) and pollute the superficial and underground water supplies. Cech $(2013$, p. 121) concluded that "the overflow of salts in the water may be harmful for some plants, aquatic species and for the human being... The salt soil may damage the plants and remove the humidity from the roots, reducing the capture of water and fertilizers."

According to Lenzi et al. (2012), $\mathrm{pH}$ is another factor that may influence soil composition, its control being crucial. The result of the raw water $\mathrm{pH}$ in the characterization reached a value of (5.38), out of line with the current standards in the legislation (CONAMA, 2005) which establish a minimum of 5.5 and maximum of 9.9. Thirty minutes after the adsorption, the $\mathrm{pH}$ reached the legal standard, becoming neutral after 240 minutes. This is fundamental for water reuse in agricultural fields, because the $\mathrm{pH}$ influences the dissolution of many minerals, with vital relevance for vegetation.

At the same time, the acidity was reduced by $66.6 \%$. The acidity in water is caused mainly by the presence of $\mathrm{CO}_{2}$, mineral acids and hydrolyzed salts. Acidity determination is very useful, since a sudden alteration in its normal value may influence the inorganic components present, in other words, in their solubilities (Metcalf and Eddy, 2015). These results confirmed that the studied process of adsorption would permit the use of this wastewater to irrigate agriculture.

With respect to the initial concentration of the chlorides, this started at $9.99 \mathrm{mg} \mathrm{L}^{-1}$ and, after 360 minutes of adsorption, minimized to $5 \mathrm{mg} \mathrm{L}^{-1}$, producing a reduction of $87.5 \%$. According to Luna et al. (2013) the chloride ion moves easily in a solution through irrigated water and when added in excess can change the groundwater quality standard. Inappropriate handling may result in the degradation of the soil through salinity. The adsorption treatment with coconut mesocarp charcoal added quality for its use in the watering process.

The result of the adsorption process was satisfactory and presented a slightly high percentage adsorbed (Figure 1a) given the contact time with the adsorbent substrate. Using Thomas's isotherm model, we analyzed the experimental data of this adsorption system, aiming to verify its applicability. The result obtained is able to be seen in Figure 1. 


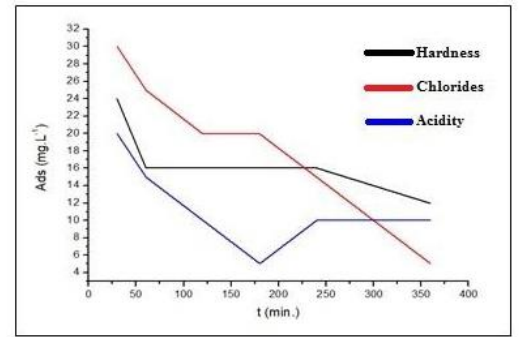

(a)

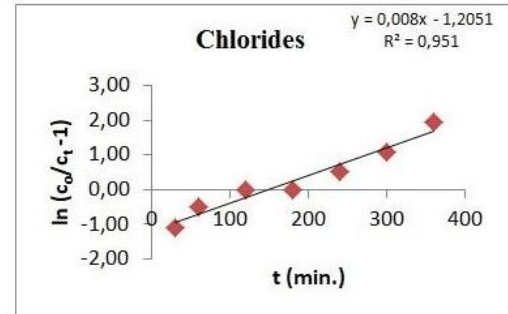

(c)

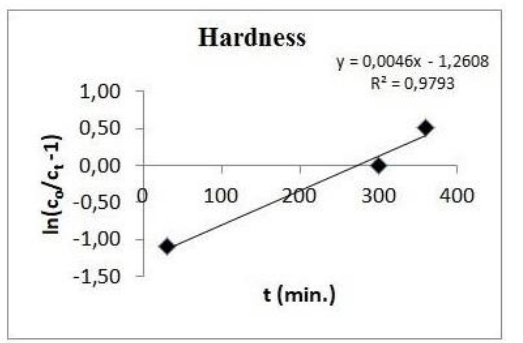

(b)

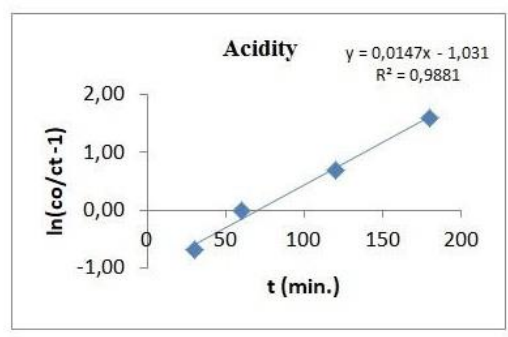

(d)

Figure 1. Adsorption and application of Thomas's isotherm for chlorides, hardness and acidity.

The Figures $(a, b, c)$ show that for the chlorides, hardness and acidity, the coefficients of correlation resulted in high values $\left(\mathrm{R}^{2}>0.95\right)$. These were acquired through the equation of the line from the respective charts, indicating that the adsorption process followed Thomas's isotherm model. This confirmed that the adsorption system in column, made on a laboratory scale, had a satisfactory performance in the removal of the parameters mentioned above.

Nevertheless, both qualitatively and quantitatively, Figure 2 shows a sudden reduction in color and turbidity. And this was only possible due to the capacity of the charcoal has to retain a great amount of suspended solids, since the adsorbent substrate is a porous material.

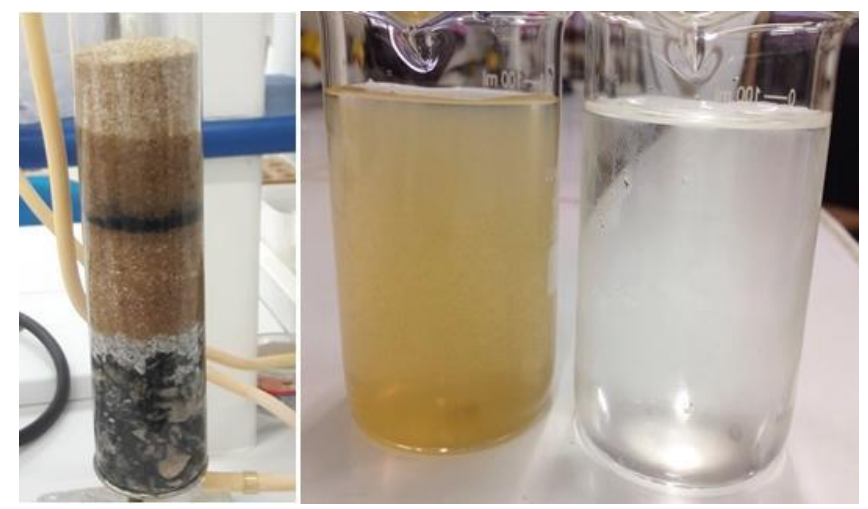

Figure 2. Implanted adsorption system and its result.

Quantitatively, the turbidity of the initial sample was high at 184 NTU, with many solid residues and suspended particles. After the column adsorption process, however, turbidity was quantified at $59 \mathrm{NTU}$ at 30 minutes of adsorption. This is a desired result, since the legislation 357 CONAMA allows a limit of 100 NTU (CONAMA, 2005).

The result of the adsorption column portrayed in Figure 2 verifies that the treatment for the effluent was satisfactory and efficient in everything, considering the quantity adsorbed according to the investigated parameters.

The adsorption capacity of the adsorbent substrate is a result of its characteristics. To identify these, an analytical study of the activated charcoal of the coco-da-baia mesocarp and the data from texture analyses, using the BET method, indicate that the adsorbent material 
presents isotherm Type I. This implies that the adsorbate distributes itself on the adsorbent surface forming a monolayer. Besides that, the presence of the isotherm implies that the adsorbent has a tendency towards chemical adsorption. Isotherms of Type I are characteristic of microporous materials, having a pore medium diameter from 0 to 20 angstroms, as is depicted at Figure 3.
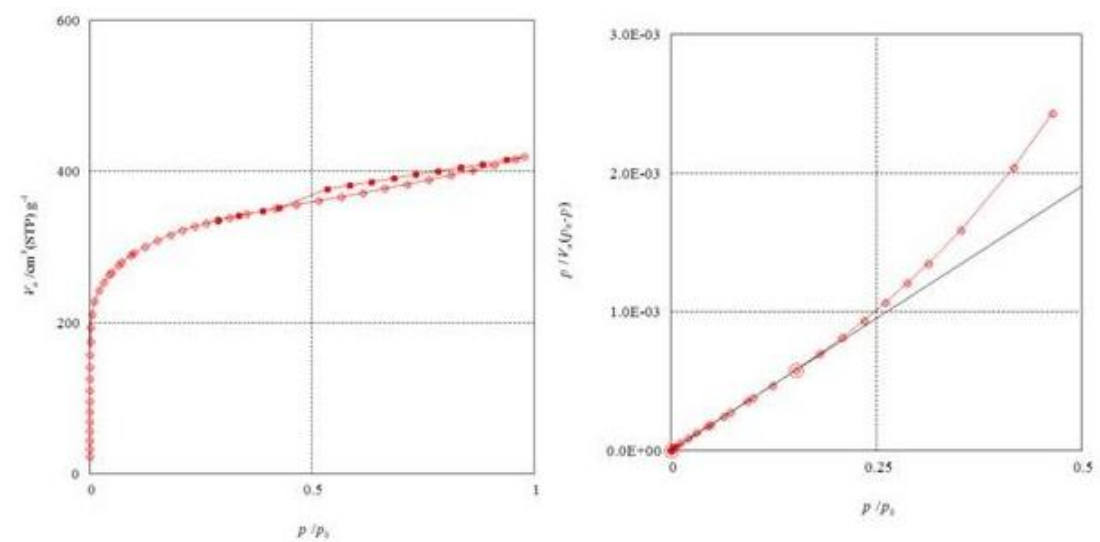

Figure 3. BET Isotherm of activated carbon of the coco mesocarp.

Medium diameter measures of the pores confirmed this hypothesis, established by the adsorption theory, since the medium diameter of the pores was around 22 angstroms. The adsorbent material presented high specific area, indicating that the adsorbent material obtained was extremely reactive, thus with a capacity for adsorption through affinity of many adsorbates.

\section{CONCLUSIONS}

In conclusion, the efficiency of the adsorbent substrate was verified, since it was able to minimize all the physical-chemical parameters, in particular, the hardness of the chlorides, acidity and $\mathrm{pH}$. The reuse strategy of the effluent under study for irrigated agriculture becomes a potential alternative for the problem of water scarcity, since the investigated adsorption technique promoted the reduction of physical and chemical parameters and added wastewater quality of ETA for Gramame. The suitability of this effluent for this purpose was proven by the correlation of the results obtained with the conditions established in the current legislation $\left(\mathrm{n}^{\circ}\right.$ 357/2005 CONAMA). Considering that the effluent was unfit for human use, the increase in water availability for agriculture was clear. Since there is a deficiency of this natural resource in the region of the Northeast where the study was carried out, this technology can be used to favorably improve the quality of the studied water. The process of column adsorption with continuous flow has already been worked on in several studies, and is especially relevant in real matrices as a proposal for the reuse of this essential resource, water.

\section{ACKNOWLEDGMENTS}

To the Federal Institute of Education, Science and Technology of Paraíba, to the CNPq for the financial investment, the Activated Carbon Laboratory of the UFPB and the LANANO.

\section{REFERENCES}

ALI, I; ASIM, M.; KHAN, T. A. Low cost adsorbents for the removal of organic pollutants from wastewater. Journal of environmental management, v. 113, p. 170-183, 2012. https://doi.org/10.1016/j.jenvman.2012.08.028 
ALI, I. The quest for active carbon adsorbent substitutes: inexpensive adsorbents for toxic metal ions removal from wastewater. Separation \& Purification Reviews, v. 39, n. 3-4, p. 95171, 2010. https://doi.org/10.1080/15422119.2010.527802

ACHON, C. L.; BARROSO, M. M.; CORDEIRO, J. S. Leito de drenagem: sistema natural para redução de volume de lodo de estação de tratamento de água. Engenharia Sanitária e Ambiental, v. 13, n. 1, p. 54-62, 2008. https://doi.org/10.1590/S141341522008000100008

AMERICAN PUBLIC HEALTH ASSOCIATION - APHA. Standard methods for the examination of water and wastewater, $21^{\mathrm{a}}$ ed. Washington, 2005.

CAMBUIM, K. B. Carvão de endocarpo de coco da baía ativado quimicamente com $\mathrm{H}_{3} \mathrm{PO}_{4}$ e fisicamente com vapor d'água: produção, caracterização e aplicações. 2009. Tese (Doutorado em Química) - Departamento de Química, UFPB, João Pessoa, 2009.

CECH, T. V. Recursos hídricos: história, desenvolvimento, política e gestão. Rio de Janeiro: LTC, 2013.

CONSELHO NACIONAL DO MEIO AMBIENTE (Brasil). Resolução n 357 de 17 março de 2005. Diário Oficial [da] União: seção 1, Brasília, DF, n. 53, p. 58-63, 18 mar. 2005.

DALFOVO, M. S.; LANA, R. A.; SILVEIRA, A. Métodos quantitativos e qualitativos: um resgate teórico. Revista Interdisciplinar Científica Aplicada, v. 2, n. 4, p. 01-13, 2008.

DE FRANCO, M. A. E. et al. Diclofenac removal from water by adsorption using activated carbon in batch mode and fixed-bed column: isotherms, thermodynamic study and breakthrough curves modeling. Journal of Cleaner Production, v. 181, p. 145-154, 2018. https://doi.org/10.1016/j.jclepro.2018.01.138

DO NASCIMENTO, R. F. et al. Adsorção: aspectos teóricos e aplicações ambientais. Fortaleza: Imprensa Universitária, 2014. 256p.

LENZI, E. et al. Introdução a química da água. São Paulo: Freitas Bastos, 2012.

LUNA, N. R. S. et al. Dinâmica do nitrato e cloreto no solo e a qualidade das águas subterrâneas do distrito de irrigação Baixo Acaraú, CE. Revista Agro@mbiente, v. 7, n. 1, p. 53-62, 2013. http://dx.doi.org/10.18227/1982-8470ragro.v7i1.1042

MATSUBARA, M. E.; COELHO, L. H. G. Evaluation of the Use of Fly Ash as a Low Cost Technology for Phosphorus Removal in Wastewater Treatment. Revista Ambiente \& Água, v. 13, n. 3, 2018. http://dx.doi.org/10.4136/ambi-agua.2166

METCALF, L.; EDDY, H. P. Tratamento de efluentes e recuperação de recursos. Rio de Janeiro: McGraw Hill Brasil, 2015.

MONTEIRO, M. S. et al. Wood (Bagassa guianensis Aubl) and green coconut mesocarp (cocos nucifera) residues as textile dye removers (Remazol Red and Remazol Brilliant Violet). Journal of environmental management, v. 204, p. 23-30, 2017. https://doi.org/10.1016/j.jenvman.2017.08.033

SILVA, R. T. S. et al. Simulação numérica e ensaios experimentais da remoção de Fe (III) da água para utilização nas indústrias alimentícias. Engenharia Sanitária Ambiental, v. 20, n. 4, p. 653-663, 2015. https://dx.doi.org/10.1590/S1413-41522015020040112681 
SOUSA NETO, V. O. Modificação química da casca do coco bruto (Cocos Nucifera) para remoção de Cu (II) de Efluente Sintético e Industrial: estudo de isoterma de adsorção, cinética e coluna de leito fixo. 170 f. 2012. Tese (Doutorado em Engenharia Civil) Departamento de Engenharia Hidráulica e Ambiental, Universidade Federal do Ceará, Fortaleza, 2012.

TELLES, D. D.; COSTA, R. H. P. G. Reúso da água: conceitos, teorias e práticas. 2. ed. São Paulo: Blucher, 2010.

YANG, J.; YU, M.; CHEN, W. Adsorption of hexavalent chromium from aqueous solution by activated carbon prepared from longan seed: Kinetics, equilibrium and thermodynamics. Journal of industrial and engineering chemistry, v. 21, p. 414-422, 2015. https://doi.org/10.1016/j.jiec.2014.02.054

YAUMI, A. L.; BAKAR, MZ Abu; HAMEED, B. H. Melamine-nitrogenated mesoporous activated carbon derived from rice husk for carbon dioxide adsorption in fixed-bed. Energy, v. 155, p. 46-55, 2018. https://doi.org/10.1016/j.energy.2018.04.183 


Ambiente \& Água - An Interdisciplinary Journal of Applied Science
ISSN 1980-993X - doi:10.4136/1980-993X
www.ambi-agua.net
E-mail: ambi.agua@gmail.com

\title{
Quantification study of Azithromycin drugs in soil, by the infrared technique with Fourier Transform (IFTR)
}

\author{
ARTICLES doi:10.4136/ambi-agua.2268
}

Received: 15 Apr. 2018; Accepted: 20 Nov. 2018

\author{
Amanda Carvalho Miranda ${ }^{1^{*}(\mathbb{D})}$; Rogerio Bonette Klepa ${ }^{1}$; \\ Thiago Michel Brito de Farias ${ }^{2}$; José Carlos Curvelo Santana ${ }^{3}$ id \\ ${ }^{1}$ Universidade Nove de Julho (UNINOVE), São Paulo, SP, Brasil \\ Programa de Pós-Graduação em Engenharia de Produção. E-mail: mirandaca1 @ hotmail.com, \\ klepao@gmail.com \\ ${ }^{2}$ Universidade Federal de São Paulo (UNIFESP), Diadema, SP, Brasil \\ Departamento de Diagnóstico por Imagem (EPM). E-mail: thg_bfarias@ hotmail.com \\ ${ }^{3}$ Universidade Estadual de Campinas (UNICAMP), Campinas, SP, Brasil \\ Programa de Pós-Graduação em Engenharia Química. E-mail: jccurvelo@yahoo.com.br \\ *Corresponding author
}

\begin{abstract}
Some classes of drugs represent greater criticality as environmental contamination; antibiotics in general represent the most potent contaminants and cause greater damage to the environment. The purpose of this work is to quantify the percentage of soil contamination by Azithromycin in presentations of $500 \mathrm{mg}$, through the application of Infrared Spectroscopy with Fourier Transform. It was verified that the drug exerts significant impacts to the environment, even in the characteristic of micropollutant, and that its extraction when performed with Pure Acetonitrile allows its residues in soil samples to be satisfactorily quantified.
\end{abstract}

Keywords: antibiotic discard, environment, Infrared Fourier Transform.

\section{Estudo da quantificação do medicamento Azitromicina no solo, pela técnica de Infravermelho com o Transformada de Fourier (IFTR)}

\section{RESUMO}

Algumas classes de drogas representam maior criticidade como contaminação ambiental; os antibióticos em geral representam os contaminantes mais potentes e que causam maiores danos ao meio ambiente. O objetivo deste trabalho é quantificar a porcentagem de contaminação do solo por Azitromicina em apresentações de $500 \mathrm{mg}$, através da aplicação da Espectroscopia no Infravermelho com Transformada de Fourier. Verificou-se que o fármaco, mesmo na característica de micropoluente, exerce impactos significativos ao meio ambiente e que sua extração, quando realizada com o Acetonitrila pura, permite quantificar satisfatoriamente seus resíduos em amostras de solo.

Palavras-chave: contaminação de solo por medicamento, descarte de antibióticos, meio ambiente. 


\section{INTRODUCTION}

The presence of drug residues in aquatic and terrestrial environments has been observed since the 1970s, and studies have shown that these emerging contaminants are in several countries around the world.

Studies over the last two decades have shown that many antibiotics are present in wastewater, animal manure and biosolids, which are mostly biologically active, and hence create potential risks to the environment (Chen et al., 2011; Papadopoulos et al., 2009; Yan et al., 2013)

Some groups of drugs deserve special attention, antibiotics and hormones among them. Antibiotics can provide resistant bacteria development and hormones can affect characteristics of aquatic organisms' reproductive systems, such as the feminization of male fish in contaminated rivers (Melo et al., 2009).

The potent antibiotic commonly used called "Azithromycin" will be treated in this work, due to its high toxicity and contamination capacity; it is produced in significant amounts of about 10,000 tons per year (Febrafarma, 2016).

As an easily accessible drug to the population, at the end of a treatment there is the disposal of unused pills as a medicine residue directly into the environment, through direct discharges into the treated or non-treated domestic sewage network in waterways. Effluents from pharmaceutical industries, rural effluents, the presence of drugs in animal manure used for soil fertilization and inadequate disposal of drugs after the shelf life expiration must also be considered (Melo et al., 2009).

Aspects related to this disposal are very important, since it is estimated that $20 \%$ of purchased drugs are destined for disposal as trash. ${ }^{3}$ This situation is aggravated by the lack of programs to collect expired drugs in the residences. It is worth mentioning that Brazil ranks among the ten largest consumers of medicines in the world, despite the high costs of these products (Febrafarma, 2016).

Antibiotics are frequently detected in different environmental matrices, with concentrations between $\mathrm{ng} / \mathrm{L}$ to low $\mathrm{mg} / \mathrm{L}$ in wastewater (Awad et al., 2014; Watkinson et al., 2009), ng/g to mg/g (dry weight, dw) in animal manure (Hu et al., 2010; Li et al., 2015), ng/g to low $\mu \mathrm{g} / \mathrm{g}$ dw in soil (Li et al., 2015; 2011; Pan et al., 2016) and $\mathrm{ng} / \mathrm{g} \mathrm{dw}$ in plant tissues (Hu et al., 2010; Pan et al., 2016; Wu et al., 2015).

The majority of antibiotics present in soil are polar compounds with ionizable functional groups, and root uptake is expected to be an important route of exposure for plants when they are grown in antibiotic-contaminated soil (Pan and Chu, 2017).

Some articles such as Melo et al. (2009) and Zuccato et al. (2006) reported that there is a concern in relation to the development of sufficiently sensitive analytical methods for the residual drugs determination in aquatic environments with detection limits in the order of $\mu \mathrm{g} / \mathrm{L}$ and $\mathrm{ng} / \mathrm{L}$.

Studies like Santos et al. (2007) showed the development of an analytical methodology for the trace element antibiotics quantification as pollutants in the aqueous medium, using the liquid chromatography with spectrophotometric detector in the ultraviolet region (HPLC-UV).

Studies by Bila and Dezotti (2003) and Almeida and Weber (2005) stated that the detection of low concentrations of different drug groups in the aquatic environment showed that solid phase extraction is the best medium for analysis, and often requires specific phases associated with high-performance liquid chromatography coupled to mass spectrometry (HPLC/MS), or high-performance liquid chromatography coupled to two mass spectrometers in series (HPLCMS/MS). 
The analytical methodology elucidated in this work aims to quantify the Azithromycin antibiotic, through the simulation of contaminated soil and its recovery; applying the FT-IR (Infrared with Fourier transform) technique. This methodology is justified by its potentialities, which translate into the performance of an analysis without destruction and often without previous sample treatment, in the device robustness, the speed and ease of execution as well as the technique selectivity.

\section{MATERIAL AND METHODS}

\subsection{Experimental Part: Sample Preparation and Soil Contamination Study}

For the accomplishment of the experiment, the soil contamination was simulated by an antibiotic that was discarded incorrectly. In order to perform the same, a container was filled with $10 \mathrm{~mL}$ of soil. In this same container, 1 tablet of Azithromycin $500 \mathrm{mg}$ was added and daily the sample was watered with $2 \mathrm{~mL}$ of water, the objective of which was to simulate the exposure of soil to rainwater. The determination of the volume of $2 \mathrm{~mL}$ of water to irrigate the samples was based on the pluviometric index of July 2016, in the city of São Paulo. Thus, the greater the contact with rainwater, the greater the spread of the antibiotic in the soil. The samples were exposed in the open air and were watered with $2 \mathrm{~mL}$ of water for 20 consecutive days. The soil samples were collected every 5 days, and the antibiotic azithromycin was extracted by washing the soil samples with pure acetonitrile solvent extractor, after which the samples were analyzed in the FT equipment The infrared spectra with diffuse reflectance of all the mixtures of pure substances were carried out in the spectral range from 1600 to $1700 \mathrm{~cm}-1$ using a resolution of 32 scans.

\subsection{Reagents}

The standard substance used in analyses to perform the calibration curve was Azithromycin PA, with $95.2 \%$ purity, supplied by Jubilant ${ }^{\circledR}$, Batch: AZDO/1008053.

Soil samples were contaminated with Azithromycin $500 \mathrm{mg}$ pills, supplied by the Brazilian National Pharmaceutical Company.

\subsection{Equipaments}

The equipment involved in the analysis was: Infrared Spectrometer with Fourier Transform, Thermo Scientific ${ }^{\circledR}$, Model Nicolet IS5 and Shimadzu ${ }^{\circledR}$ Scale, Model AUY220; in addition to Acetonitrile organic solvent, Merck ${ }^{\circledR}$ Batch: I623030, validity 02/31/2015.

\subsection{Extracting Solvent}

For the sample extraction, the best extracting solvent was evaluated by means of an extraction test, for which approximately $0.9 \mathrm{~g}$ of soil sample were weighed in triplicate and each was contaminated with $0.1 \mathrm{~g}$ of Azithromycin.

From this preparation, three extracting solvents were used in differentiated compositions to evaluate which would have the best removal potential of Azithromycin in the soil.

Three different concentrations of this extracting solvent were prepared: 50\% Acetonitrile $+50 \%$ Water, $80 \%$ Acetonitrile $+20 \%$ Water and pure Acetonitrile; the samples were submitted to equal amounts of $20 \mathrm{ml}$ of these solvents.

The next step to ensure the material extracting was the agitation process and constant mixing of the soil sample contaminated with its respective extracting solvents for 10 minutes with a magnetic bar. To obtain the samples spectra, they were filtered in a paper filter and the recovered samples were obtained.

Extraction performance ( $\% \mathrm{R})$ was calculated from Equation 1:

\section{IPABH}


$\% R=\left(\frac{C_{A z} \cdot V_{e}}{M_{A z}}\right) \cdot 100 \%$

Where: $\mathrm{M}_{\mathrm{Az}}$ is the Azithromycin mass inserted into the soil, $\mathrm{C}_{\mathrm{Az}}$ is the Azithromycin concentration analyzed in the extracting solvent and $\mathrm{V}_{\mathrm{e}}$ is the extracting solvent volume.

\subsection{Obtaining the Standard Solution and Calibration Curve}

The spectral region choice to construct the calibration curve model was based on the elaboration of the pure Azithromycin substance spectrum in ten different concentrations. The model used for the calibration curve was based on the Lambert-Beer Law.

A stock solution was prepared after weight mass concentration correction as a function of the power purity of the Azithromycin standard used $(950.2 \mu \mathrm{g} / \mathrm{mg})$.

The $1.0524 \mathrm{~g}$ mass of pure Azithromycin was then weighed into a $100 \mathrm{ml}$ volumetric flask; the dilution was performed with a 50\% mixture of Ultra Purified Water and 50\% Acetonitrile organic solvent. This solution presented a $9.9999 \mathrm{~g} / \mathrm{L}$ concentration of Azithromycin stock solution from which standard solutions diluted at concentrations of $0.5 \mathrm{~g} / \mathrm{L}$ to $7.0 \mathrm{~g} / \mathrm{L}$ were prepared. The solution's $\mathrm{pH}$ remained around 7.0.

Each of the standard solutions diluted by FT-IR with 32 scans of resolution was individually read and thus the curves were obtained to determine the ratio of the concentrations in relation to their areas, which were evaluated from Microcal Origin ${ }^{\circledR}$ Software. The choice band to perform the calibration curve was determined in the $1600-1700 \mathrm{~cm}^{-1}$ vibrational energy region.

After establishing and quantifying the concentration $\mathrm{x}$ area ratio, the data were treated with scatter plots in Excel $^{\circledR}$.

\section{RESULTS AND DISCUSSION}

The spectral region choice was based on a study by Mallah et al. (2011), who developed a technique for the determination of Azithromycin via FT-IR by compacting the solid substance with $\mathrm{KBr}$ pellets. In this work, the spectral range of 1744 to $1709 \mathrm{~cm}^{-1}$ was used to analyze the concentration of the substance due to the linearity presented with the areas generated by the vibration band of the $\mathrm{C}=\mathrm{O}$ group present in the chemical structure of Azithromycin, according to Figure 1. This model allowed comparisons of analytical techniques and provided a guidance on the spectral region of the best evidence for Azithromycin substance. Even without KBr pellet compaction, it was possible to determine the Azithromycin recovery only with the use of Acetonitrile organic solvent.

After determining the best spectral band to work, it was possible to construct the calibration curve. The spectra reproduced in the overlapping concentrations, according to Figure 2, show that the spectral region in the range of 1600 to $1700 \mathrm{~cm}^{-1}$ provided better reproducibility for calibration curve execution, without compaction in $\mathrm{KBr}$ pellets, only with extraction in Acetonitrile.

\subsection{Calibration Curve}

Obtaining the calibration curve that relates the concentration of the samples with their respective areas proves the linearity of the method. To confirm the validity of the analytical method, the calibration was performed in triplicate on different dates and the results and the standard deviation obtained were compared in relation to the three curves.

It was observed that as the concentrations increased, the area obtained was proportional, in the $1600-1700 \mathrm{~cm}^{-1}$ spectral region. 


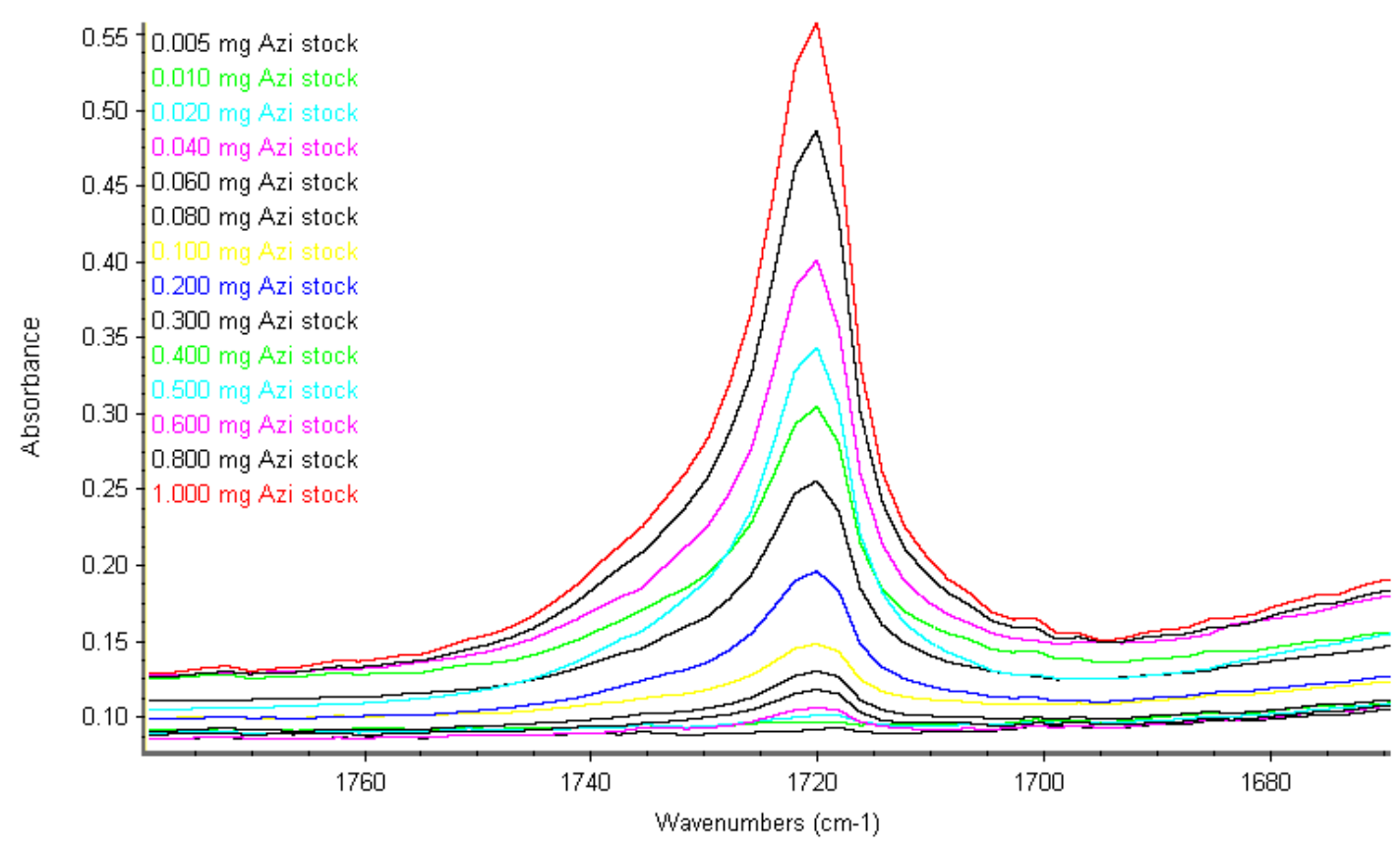

Figure 1. Results obtained by band $\mathrm{C}=\mathrm{O}$ Carbonyl's determination, in Azithromycin compacted with $\mathrm{KBr}$.

Source: Adapted from Mallah (2011).

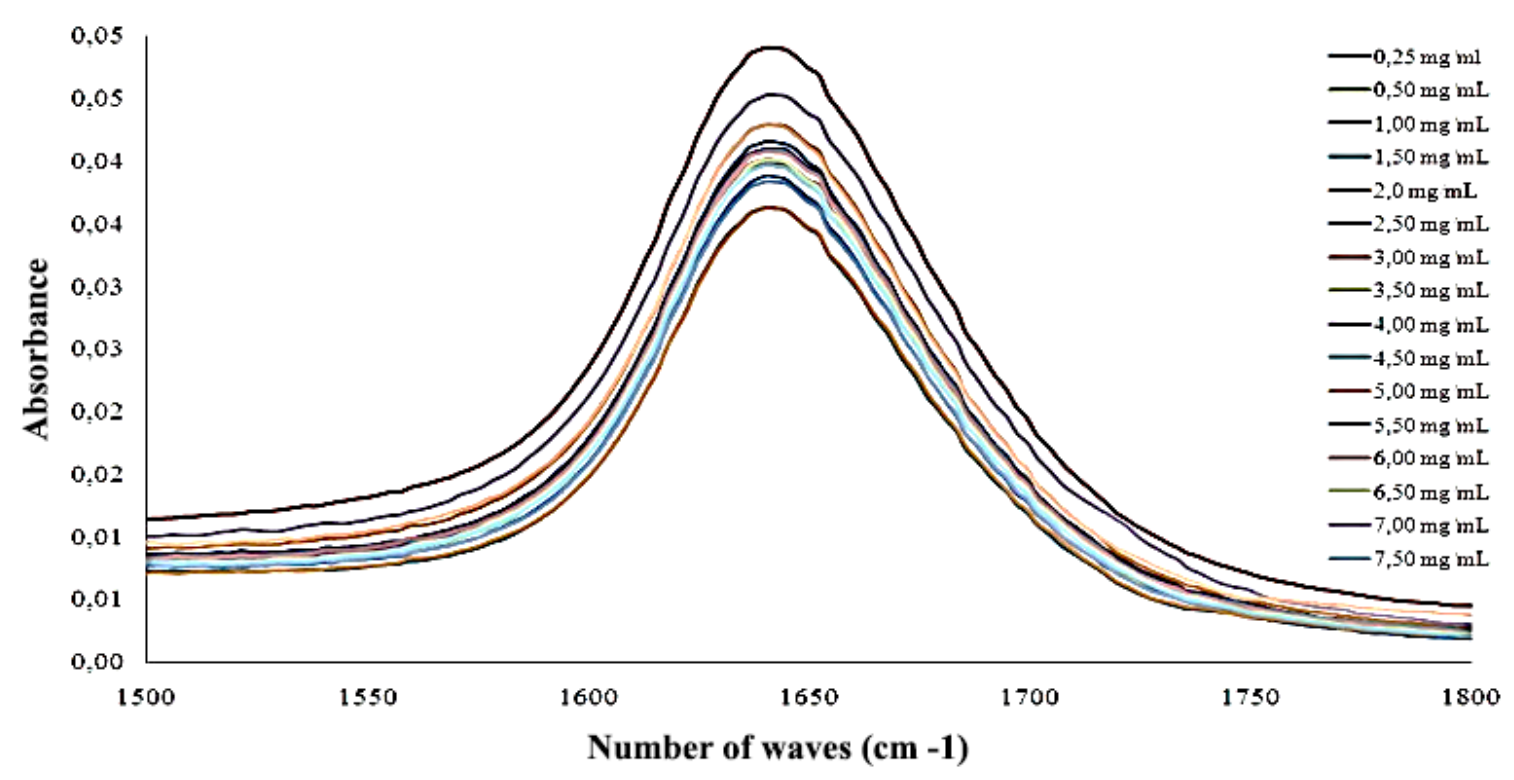

Figure 2. Peak of interest for calibration at 1600-1700 range.

Figure 3 presents the best response obtained for the data dispersion, which can be easily presented by a straight line, which coefficient of co-relation $(\mathrm{R})$ obtained was 0.999 , according to the calibration curve 1, represented by Equation 2 .

$$
C=0,082 \cdot A+4,0963 \quad \mathrm{R}=0.9991
$$

After application of the $\mathrm{t}$ Student test, the following results were obtained: the value of $\mathrm{t}$ calculated was 0.04199 and the value of the standard deviation grouped, $\mathrm{S}_{\mathrm{G}}$, was 2.17527. Thus, the limit of confidence could be expressed by Equation 3:

$L C=\mu \pm 0,091352$

\section{IPABH}




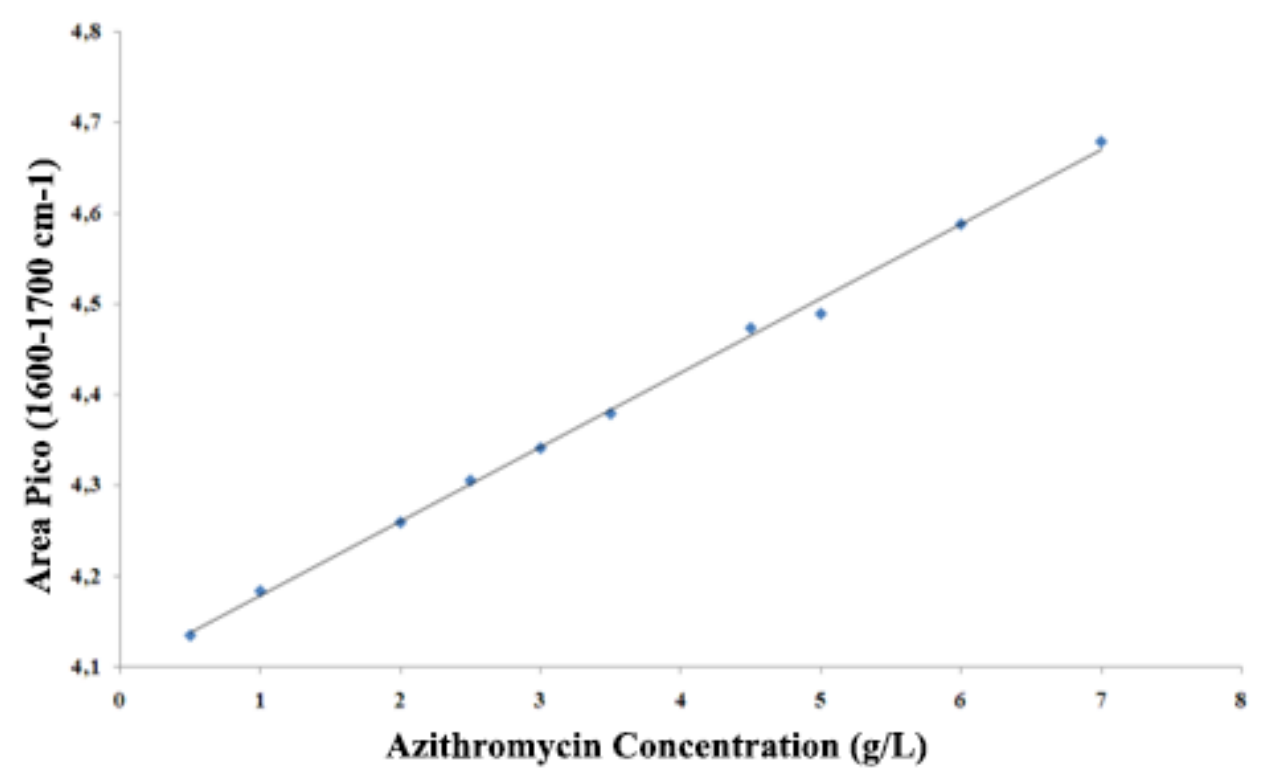

Figure 3. Linearity obtained for the first calibration curve.

\subsection{Choosing the Extracting Solution}

Extraction test was efficient according to Table 1, where it was possible to prove that pure Acetonitrile was more efficient in the extraction process of the Azithromycin drug from the soil.

Table 1. Extraction efficiency of the solvents tested.

\begin{tabular}{cccccc}
\hline Test & \% Extracting Solvent & $\mathbf{C}_{\mathbf{A z}}(\mathbf{g} / \mathbf{L})$ & $\mathbf{C}_{\mathrm{AzCalc} .}(\mathbf{g} / \mathbf{L})$ & $\boldsymbol{\%}$ Recovering & Deviation \\
\hline 1 & ACN:H20 (50:50) & 4.5950 & 2.3255 & 49.5840 & 0.1479 \\
2 & ACN:H20 (80:20) & 4.6900 & 3.6253 & 77.8643 & 0.1263 \\
3 & ACN & 4.7150 & 4.9331 & 104.625 & 0.2556 \\
\hline
\end{tabular}

Where: $\mathrm{C}_{\mathrm{Az}}=$ expected azithromycin concentration, $\mathrm{C}_{\mathrm{AzCalc}}=$ recovered concentration.

Comparing to a study by Eickhoff et al. (2009), the residual drug detection in the aquatic environment and in the soil, in the range of $\mu$ g.L-1 and ng.L-1, the methods described in the literature are based on solid phase extraction, in some cases, derivatization of the acidic substance and subsequent determination of the derivative by gas chromatography coupled to mass spectrometry (GC-MS) or high-performance liquid chromatography coupled to mass spectrometry (HPLC-MS).

Thus, it was found that it is possible to extract Azithromycin from soil with an organic solvent, without the need for a sample derivatization test or acid digestion.

Using the extraction deviations that obtained the best recovery, we will have the limits of detection (LD) and quantification (LQ), as follows Equations 4 and 5:

$$
\begin{aligned}
& L D=3 \cdot 0,25563=0,76689 g / L \\
& L Q=10 \bullet 0,25563=2,55630 g / L
\end{aligned}
$$

\subsection{Samples results}

Figure 4 represents the spectra overlap of Azithromycin $50 \mathrm{mg}$ samples in soil, where the work spectral range of the 1600-1700 cm-1 vibrational energy bands was considered, representing the $\mathrm{C}=0$ Carbonyl's stretching, used for the quantification of the sample in relation to the soil. 


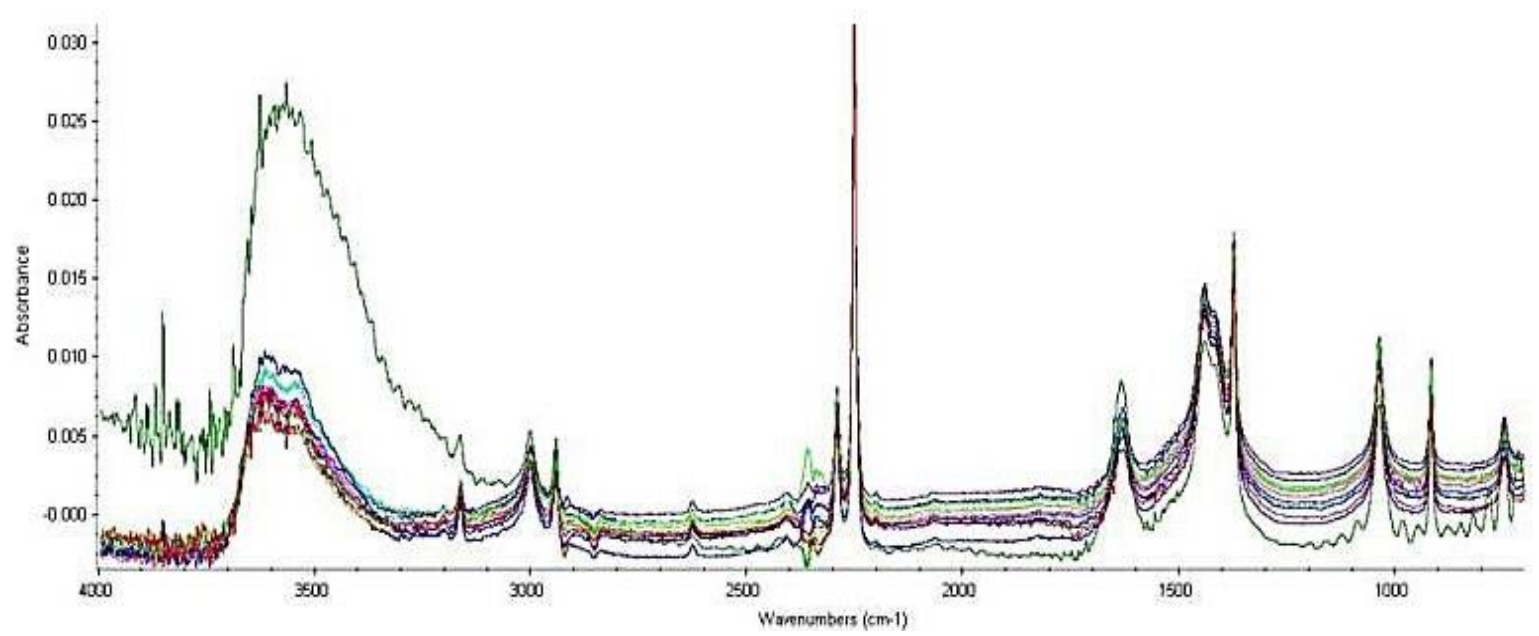

Figure 4. Spectra overlap of contaminated soil samples with $500 \mathrm{mg}$ Azithromycin.

Table 2 represents the \%'s mean recovery obtained in the soil samples' triplicates when exposed to the $500 \mathrm{mg}$ Azithromycin concentration for a period of 0 to 20 days.

Table 2. Results for soil contamination with $500 \mathrm{mg}$ Azithromycin.

\begin{tabular}{ll}
\hline Exposure Days & $\%$ drug recovery \\
\hline 5 days $-500 \mathrm{mg}$ concentration & $21.35 \%$ Azithromycin in soil recovery \\
10 days $-500 \mathrm{mg}$ concentration & $13.48 \%$ Azithromycin in soil recovery \\
15 days $-500 \mathrm{mg}$ concentration & $11.40 \%$ Azithromycin in soil recovery \\
20 days $-500 \mathrm{mg}$ concentration & $10.14 \%$ Azithromycin in soil recovery \\
\hline
\end{tabular}

According to the presented results, it was possible to verify that the longer the exposure time of the Azithromycin drug in contact with the soil, being influenced by the dragging degree of the $2 \mathrm{ml}$ of water projected daily on the sample, the greater its recovery. That is, compared to everyday situations, when discarding the drug-containing packaging incorrectly, when it is exposed to the environment and undergoes influences from external factors such as temperature and rainfall drag, these drugs can contaminate soil.

Rabølle and Spliid (2000) conducted soil column studies of four antibiotics under saturated steady-state conditions and found that most of them remained in the top few centimetres of the soil columns. Surface soil has a higher concentration of organic matter than subsurface layers, which promotes the adsorption of antibiotics that decreases their downward leaching. The application of animal manure in soil may decrease the leachability of tetracyclinehydrochloride (Jones et al., 2005). Soil pH also affects the fraction of ionized organic compounds, and most antibiotics are fairly water soluble and able to ionize according to the soil Ph. (Figueroa-Diva et al., 2010; Srinivasan et al., 2013).

\section{CONCLUSION}

This work can be affirmed as an application proposal of an analytical methodology FT-IR for Azithromycin antibiotic characterization and quantification in soil.

The Pure Acetonitrile extraction method evaluated proved to be effective for removal of the antibiotic from soil, and the relation of the sample exposure time, the time conditions, temperature and rainfall index also proved to simulate what occurs in the environment.

As the days passed, with constant exposure the samples became increasingly "diluted" and interacted with the soil; it was also found that the drug's $500 \mathrm{mg}$ concentration provided significant recoveries in percentages.

\section{IPABH}


The study also highlights the need to collect and dispose of medicines correctly, because when in contact with soil they may bioaccumulate damage organisms in the food chain.

\section{REFERENCES}

ALMEIDA, G. A.; WEBER, R. R. Fármacos na Represa Billings. Revista Saúde e Ambiente, v. 6 , p. 7-13, 2005.

AWAD, Y. M.; KIM, S. C.; EL-AZEEM, S. A. M. A.; KIM, K. H.; KIM, K. R.; KIM, K. Veterinary antibiotics contamination in water, sediment, and soil near a swine manure composting facility. Environmental Earth Science, v. 71, p. 1433-1440, 2014. https://doi.org/10.1007/s12665-013-2548-z

BILA, D. M.; DEZOTTI, M. Fármacos no Meio ambiente. Química Nova, v. 26, n. 04, p. 523530, 2003.

CHEN, F.; YING, G. G.; KONG, L. X.;WANG, L.; ZHAO, J. L.; ZHOU, L. J. Distribution and accumulation of endocrine-disrupting chemicals and pharmaceuticals in wastewater irrigated soils in Hebei, China. Environmental Pollution, v. 159, p. 1490-1498, 2011. https://doi.org/10.1016/j.envpol.2011.03.016

EICKHOFF, P.; HEINECK, I.; SEIXAS, J. L. Gerenciamento e destinação final de medicamentos: uma discussão sobre o problema. Revista Brasileira de Farmácia, v. 90, n. 01, p. 64-68, 2009.

FEDERAÇÃO BRASILEIRA DA INDÚSTRIA E COMÉRCIO FARMACÊUTICO. Website. Available in: www.febrafarma.org.br. Access: 20 Ag. 2016.

FIGUEROA-DIVA, R. A.; VASUDEVAN, D.; MACKAY, A. A. Trends in soil sorption coefficients within common antimicrobial families. Chemosphere, v. 79, p. 786-793, 2010. https://doi.org/10.1016/j.chemosphere.2010.03.017

HU, X. G.; ZHOU, Q. X.; LUO, Y. Occurrence and source analysis of typical veterinary antibiotics in manure, soil, vegetables and groundwater from organic vegetable bases, northern China. Environmental Pollution, v. 158, p. 2992-2998, 2010., https://doi.org/10.1016/j.envpol.2010.05.023 JONES, A. D.; BRULAND, G. L.; AGRAWAL, S. G.; VASUDEVAN, D. Factors influencing the sorption of oxytetracycline to soils. Environmental Toxicology And Chemistry, v. 24, p. 761-770, 2005. https://doi.org/10.1897/04-037R.1

LI, R.; ZHANG, Y.; LEE, C. C.; LIU, L.; HUANG, Y. Hydrophilic interaction chromatography separation mechanisms of tetracyclines on amino-bonded silica column. Journal of Separation Science, v. 34, p. 1508-1516, 2011. https://doi.org/10.1002/jssc.201100130

LI, C.; CHEN, J. Y.; WANG, J. H.; MA, Z. H.; HAN, P.; LUAN, Y. X. Occurrence of antibiotics in soils and manures from greenhouse vegetable production bases of Beijing, China and an associated risk assessment. Science of the Total Environment, v. 521522, p. 101-107, 2015. https://doi.org/10.1016/j.scitotenv.2015.03.070

MALlAH, M. A.; SHERAZI, S. T. H.; MAHEZAR, S. A.; RAUF, A. Assessment of azithromycin in Pharmaceutical Formulation by Fourier-transform Infrared (FT-IR) Transmission Spectroscopy. Pakistan Journal of Analytical \& Environmental Chemistry, v. 12, n. 1/2, p. 61-67, 2011. 
MELO, S. A. S.; TROVÓ, A. G.; BAUTITZ, I. R.; NOGUEIRA, R. F. P. Degradação de fármacos residuais por processos oxidativos avançados. Química Nova, v.32, n.1, p. 188197, 2009. http://dx.doi.org/10.1590/S0100-40422009000100034

PAN, M.; WONG, K. C.; CHU, L. M. Distribution of antibiotics in wastewater-irrigated soils and their accumulation in vegetables crops in the Pearl River Delta, southern China. Journal of Agricultural And Food Chemistry, v. 62, p. 11062-11069, 2016. http://dx.doi.org/10.1021/jf503850v

PAN, M.; CHU, L. Fate of antibiotics in soil and their uptake by edible crops. Science of the $\begin{array}{llllll}\text { Total Environment, } & \text { v. 599-600, p. 500-512, }\end{array}$ https://doi.org/10.1016/j.scitotenv.2017.04.214

PAPADOPOULOS, F.; PARISSOPOULOS, G.; PAPADOPOULOS, A.; ZDRAGAS, A.; NTANOS, D.; PROCHASKA, C. Assessment of reclaimed municipal wastewater application on rice cultivation. Environmental Management, v. 43, p. 135-143, 2009. https://doi.org/10.1007/s00267-008-9221-4

RABØLLE, M.; SPLIID, H. Sorption and mobility of metronidazole, olaquindox, oxytetracycline and tylosin in soil. Chemosphere, v. 40, p. 715-722, 2000. https://doi.org/10.1016/S0045-6535(99)00442-7

SANTOS, J. H. Z. dos; PIZZOLATO, T. M.; CUNHA, A. C. B. Desenvolvimento de metodologia analítica para quantificação de fármacos em meio aquático por extração em fase sólida e High Performance Liquid Chromatography (HPLC). Revista de Ciências Ambientais, v. 2, p. 19-34, 2007. http://dx.doi.org/10.18316/167

SRINIVASAN, P.; SARMAH, A. K.; MANLEY-HARRIS, M. Co-contaminants and factors affecting the sorption behaviour of two sulfonamides in pasture soils. Environmental Pollution, v. 180, p. 165-172, 2013. https://doi.org/10.1016/j.envpol.2013.05.022

YAN, C.; YANG, Y.; ZHOU, J.; LIU, M.; NIE, M.; SHI, H. et al. Antibiotics in the surface water of the Yangtze estuary: occurrence, distribution and risk assessment. $\begin{array}{llllll}\text { Environmental Pollution, } & \text { v. } & \text { 175, } & \text { p. }\end{array}$ https://doi.org/10.1016/j.envpol.2012.12.008

WATKINSON, A. J. MURBY, E. J.; KOLPIN, D. W.; COSTANZO, S. D. The occurrence of antibiotics in an urban watershed: from wastewater to drinking water. Science of the $\begin{array}{llllll}\text { Total Environment, } & \text { v. 4009, }\end{array}$ https://doi.org/10.1016/j.scitotenv.2008.11.059

WU, X. Q.; DODGEN, L. K.; CONKLE, J. L.; GAN, J. Plant uptake of pharmaceutical and personal care products from recycled water and biosolids: a review. Science of the Total Environment, v. 536, p. 655-666, 2015. https://doi.org/10.1016/j.scitotenv.2015.07.129

ZUCCATO, E. et al. Pharmaceuticals in the environment in italy: causes, occurrence, effects and control. Environmental Science and Pollution Research, v. 13,p. 15- 21, 2006. https://doi.org/10.1065/espr2006.01.004 


\begin{tabular}{|c} 
Ambiente \& Água - An Interdisciplinary Journal of Applied Science \\
ISSN 1980-993X - doi:10.4136/1980-993X \\
www.ambi-agua.net \\
E-mail: ambi.agua@gmail.com
\end{tabular}

\title{
Assessment of digital elevation models to obtain morphometric characteristics in relief transition region
}

\author{
ARTICLES doi:10.4136/ambi-agua.2280
}

Received: 21 May 2018; Accepted: 01 Dec. 2018

\begin{abstract}
Kevin Nunes Ficher ${ }^{1(\mathbb{D})}$; Donizete dos Reis Pereira ${ }^{\text {*(D) }}$; Josiane Silva Oliveira ${ }^{1(\mathbb{D})}$ André Quintão de Almeida ${ }^{2}$; ; Eduardo Morgan Uliana ${ }^{3}$ (D)

${ }^{1}$ Universidade Federal de Viçosa (UFV), Florestal, MG, Brasil

Instituto de Ciências Agrárias (IAF). E-mail: kevin.nficher@gmail.com,donizete.pereira@ufv.br, josianerso@gmail.com

${ }^{2}$ Universidade Federal do Sergipe (UFS), São Cristovão, SE, Brasil

Departamento de Engenharia Agrícola (DEAGRI). E-mail: andreqa@gmail.com

${ }^{3}$ Universidade Federal de Mato Grosso (UFMT), Sinop, MT, Brasil

Instituto de Ciências Agrárias e Ambientais (ICAA). E-mail: morganuliana@gmail.com

*Corresponding author
\end{abstract}

\begin{abstract}
The purpose of this study was to evaluate the performance of Digital Elevation Models (DEMs) in the morphometric characterization of a basin located in a transitional region between the São Francisco Plateau, São Francisco Depression and Espinhaço Range reliefs. For the study, four DEMs were generated by interpolation of the SRTM data and topographic maps, using the Topo To Raster interpolator with and without mapped hydrography support, available in ArcGIS ${ }^{\circledR} 9.3$ software. Another DEM was obtained from the SRTM original data. From the generated DEMs, the morphometric characteristics of the basin were determined and compared to those obtained from topographic maps, denominated reference (REF), by means of percentage errors. The evaluation was also performed in a qualitative way, comparing the drainage and the basin delineations. In general, the DEMs obtained with the support of the mapped hydrography (SRTM-TRH and CT-TRH) provided the best results, with small errors, mainly for the main morphometric characteristics of the basin, drainage area and main river length, which ranged from 0.38 to $1.12 \%$ and 5.28 to $7.07 \%$, respectively. On the other hand, the DEMs generated without the support of the mapped hydrography (SRTM-O, SRTM-TR and CT-TR) presented major errors mainly in determining the drainage area and length of the main river, which varied from 18.1 to $26.6 \%$ and 26.7 to $34.4 \%$, respectively. These occurred due to a deviation of the main river in the São Franciscana Depression region, which allows us to conclude on the necessity and importance of evaluating DEMs before their use.
\end{abstract}

Keywords: srtm, topographical maps, topo to raster.

\section{Avaliação de modelos digitais de elevação para obtenção de características morfométricas em região de transição de relevos}

\section{RESUMO}

Objetivou-se com este estudo, avaliar o desempenho de MDEs na caracterização morfométrica de uma bacia hidrográfica situada em região de transição entre os relevos Planalto 
São Franciscana, Depressão São Franciscana e Serra do Espinhaço. Para o estudo, foram gerados quatro MDEs por interpolação dos dados do SRTM e de cartas topográficas, utilizando o interpolador Topo To Raster com e sem suporte da hidrografia mapeada, disponível no software ArcGIS ${ }^{\circledR}$ 9.3. Outro MDE foi obtido a partir dos dados originais do SRTM. A partir dos MDEs gerados, determinaram-se as características morfométricas da bacia e comparou-as àquelas obtidas de cartas topográficas, denominadas de referência (REF), por meio da determinação de erros percentuais. A avaliação também foi realizada de maneira qualitativa comparando as drenagens e as delimitações da bacia. De um modo geral, os MDEs obtidos com o suporte da hidrografia mapeada (SRTM-TRH e CT-TRH) proporcionaram os melhores resultados, com pequenos erros, principalmente, para as principais características morfométricas da bacia, área de drenagem e comprimento do rio principal, os quais variaram de 0,38 a $1,12 \%$ e 5,28 a 7,07\%, respectivamente. Por outro lado, os MDEs gerados sem o suporte da hidrografia mapeada (SRTM-O, SRTM-TR e CT-TR) apresentaram grandes erros, principalmente, na determinação da área de drenagem e comprimento do rio principal, os quais variaram de 18,1 a 26,6\% e 26,7 a 34,4\%, respectivamente. Esses ocorreram em razão de um desvio do rio principal na região da Depressão São Fransciscana, o que nos permite concluir sobre a necessidade e importância de se avaliar MDEs antes de sua utilização.

Palavras-chave: cartas topográficas, srtm, topo to raster.

\section{INTRODUCTION}

The knowledge of morphometric characteristics of watersheds is fundamental in the development of hydrological studies for the purposes of better planning and management of water resources (Aher et al., 2014). These characteristics are important for: the estimation of the runoff depth and time of concentration of the flow in the basin (Silva et al., 2006; Abdulkareem et al., 2018; Mudashiru et al., 2018); the regionalization of flows (Fioreze et al., 2008; Bassiouni et al., 2016); hydrological modeling (Chaplot et al., 2006; Cecílio et al., 2013; Meraj et al., 2015; Abdulkareem et al., 2018); and as indicators of the degree of vulnerability of the basin to phenomena such as floods and soil erodibility (Esper Angillieri, 2008; Gebrehiwot et al., 2011; Ameri et al., 2018).

Currently, the morphometric characteristics of basins are determined automatically by means of the processing of digital data of elevation of the terrain, using tools of geoprocessing and Geographic Information Systems (GIS) (Cunha and Bacani, 2016). The digital terrain elevation information is represented by a numerical structure of data corresponding to altitude spatial distribution and of the terrain surface, called Digital Elevation Model (DEM) (Oliveira et al., 2010).

The DEMs may be obtained by remote sensing data or generated from the interpolation of point topographical data and contour lines extracted from topographic maps (Oliveira et al., 2010; Cecílio et al., 2013). In Brazil, the most common data source for the generation of the DEMs are the contour lines, and of supplementary form, the hydrography and the elevation points obtained from topographic maps. However, the scarcity of such data in certain places, makes the information from images and remote sensors of great importance for the generation of these models (Chagas et al., 2010).

The quality of the DEMs is fundamental to the success of hydrological studies, especially when it comes to modeling (Chaplot et al., 2006), because depending on the characteristics of the DEM (scale, resolution and origin), the automatic delineation of a basin and, consequently, its morphometric characteristics, may differ significantly (Pires et al., 2005; Alcaraz et al., 2009; Seyler et al., 2009; Cecílio et al., 2013). Thus, several studies have been conducted to analyze, compare and update the information on the earth's surface, obtained by means of 
remote sensing data or by cartographic bases.

In this sense, Woodrow et al. (2016) analyzed the effects of resolution, origin and conditioning techniques of DEM on spatial and statistical distribution of field-scale hydrological attributes for a 12,000 ha agricultural watershed in southwestern Ontario, Canada. The basins were delimited using the surface drainages modeled from LiDAR data, interpolated in DEMs of resolution of 1, 5 and $10 \mathrm{~m}$, and a photogrammetric DEM of $10 \mathrm{~m}$ resolution. The results showed that the variation in the resolution of the DEM resulted in significant differences in the spatial and statistical distributions of the drainage areas and in the downslope flowpath length. LiDAR DEMs are derived from airborne laser surveys and because they are high resolution they have had a major impact on topographic analysis of the earth's surface in many countries.

The effects of the resolution of the DEM on surface drainage were also investigated by Ariza-Villaverde et al. (2015), when analyzing the influence of the resolution of the DEM in the extraction of the drainage network of watersheds using multifractal analysis. The authors tested three DEM resolutions in four river basins with different levels of drainage network distribution, aiming to find the most adequate value of the accumulated flow threshold. They observed that the limit value of adequate flow accumulation increases as the DEM resolution increases and shows a greater variability for basins with lower drainage densities.

Issues related to the scale, precision and sensitivity of DEM data, too, were studied by Das et al. (2016). The authors individually extracted and analyzed the relief, surface area, size, shape and properties of a river basin in a mountainous region from the following DEMs: derived from Advanced Spaceborne Thermal Emission and Reflection Radiometer (ASTER V2), Shuttle Radar Topography Mission (SRTM V4, C-Band, 3 arc-second), Cartosat-1 (CartoDEM 1.0) and topographical maps (R.F. 1:250,000 and 1:50,000). The authors observed that DEMs derived from the 1: 50,000 topographic map and ASTER V2 data are more accurate and consistent in terms of absolute accuracy than the other DEM data products generated or available, based on the morphometric parameters extracted from each.

Cecílio et al. (2013), also in mountainous conditions, evaluated the precision of DEMs for the automatic delineation of a river basin. The DEMs evaluated originated from radar images (SRTM) and spatial interpolation of contours (1:50,000 scale), with a spatial resolution of $10 \mathrm{x}$ $10 \mathrm{~m}$. The authors verified that the DEM generated from the contour lines and hydrographic mapped using the interpolator Top To Raster presented the best performance of representation of relief of the basin. Oliveira et al. (2010) found little significant differences for most morphometric characteristics when comparing Shuttle Radar Topography Mission (SRTM) data with data of topographic maps on a scale of 1:100,000; however, they recommended the comparison of the hydrography obtained from SRTM data with those obtained from remote sensing data or topographic maps.

Other studies on the evaluation of DEMs, with objectives different from those presented previously, can also be found in the literature, such as that of Chagas et al. (2010), which compared different DEMs (resolution of $30 \times 30 \mathrm{~m}$ ) for application in a digital mapping of soils. Qualitative analysis identified that the DEM obtained from topographic maps presented superior quality to the DEMs derived from remote sensors, since these resulted in errors that could compromise the relations between attributes of the terrain and the conditions of the soils.

Although many studies on evaluation of DEMs have already been made, with different objectives, analysis has not been verified in the determination of the morphometric characteristics of basins in conditions of transition of reliefs. Close to the above, the study by Chaplot et al. (2006) evaluated the accuracy of interpolation techniques to obtain DEMs in flat (western France) and mountainous (northern Laos) areas in conditions of microplots, slopes and catchment with different sample density of altitude. In this work, the authors evaluated the precision of the techniques to the determination of altitude, observing few differences between 
them when the sampling density was high. However, they stressed the importance of performing other studies that evaluate the quality of the DEM in attributes more sensitive to the interpolation technique selection than the altitude itself, such as: slope angle, slope curvature, drainage network and catchment boundaries, because many GIS applications depend on them.

Thus, the objective of this study was to evaluate the performance of different DEMs to obtain morphometric characteristics of a river basin located in a transition region between the reliefs São Francisco plateau, São Franciscana depression and Espinhaço Range, aiming to give subsidies for hydrological studies at the site. In the sequence, the methodology used in the work is presented, highlighting the form of obtaining the DEMs and of the morphometric characteristics, the main results obtained and discussions, besides the main conclusions reached with the research.

\section{MATERIALS AND METHODS}

\subsection{Study area}

The study was conducted in the Peixe River Basin, which has a drainage area of approximately $580 \mathrm{~km}^{2}$. Located in the central region of the State of Minas Gerais, Brazil, between the coordinates $19^{\circ} 25^{\prime} 00^{\prime \prime}$ and $19^{\circ} 42^{\prime} 00^{\prime \prime} \mathrm{S}$ and $44^{\circ} 40^{\prime} 00^{\prime \prime}$ and $45^{\circ} 00^{\prime} 00^{\prime \prime} \mathrm{W}$, in one of the most important river basins in the country, the São Francisco River Basin, the basin of the Peixe River has transition between the reliefs São Francisco plateau, São Franciscana depression and Espinhaço Range (Figure 1).

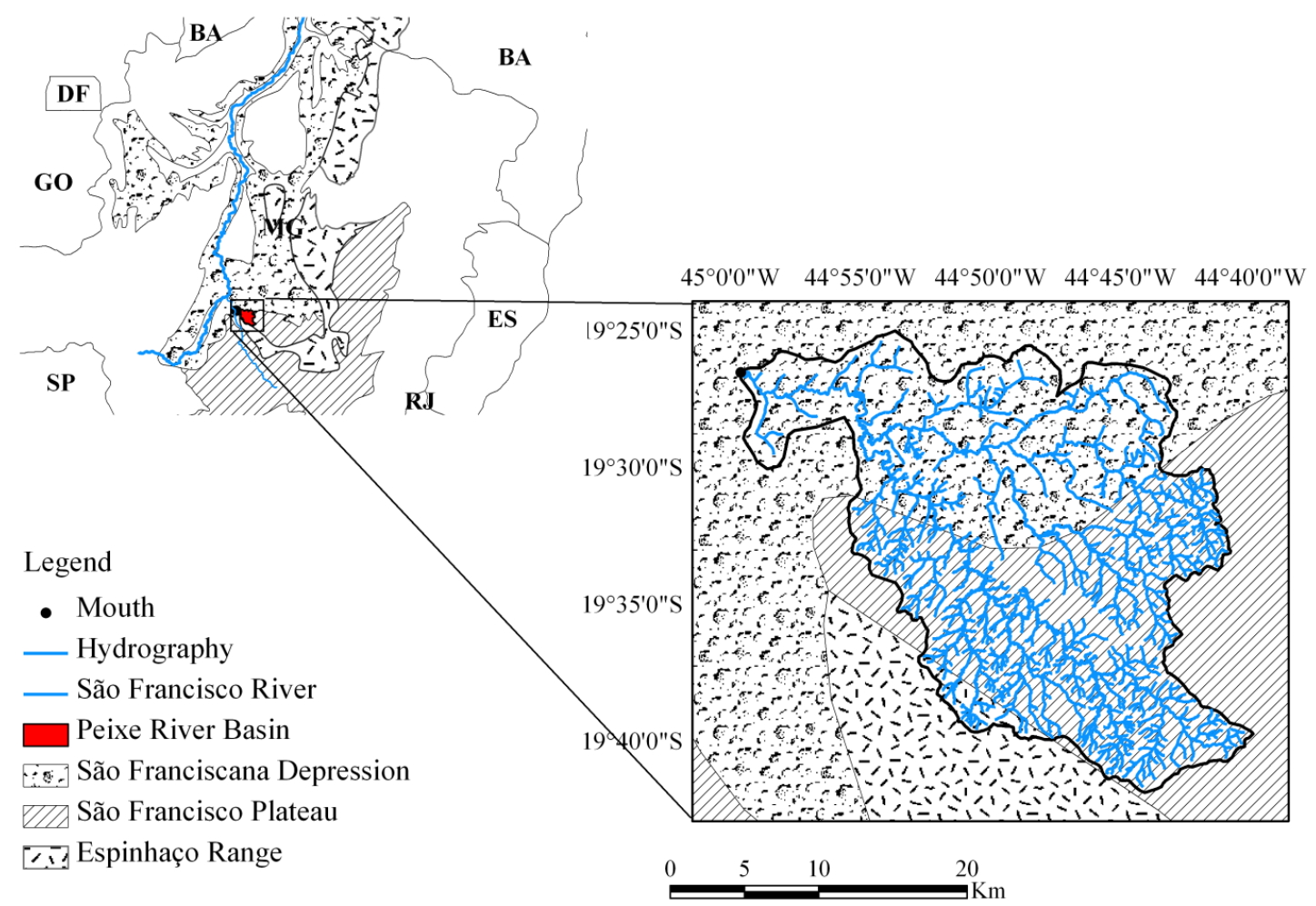

Figure 1. Location of study area.

The São Francisco plateau is composed of tabular surfaces called "chapadas", which are intersected by the headwaters of deepened draining. The relief is distinguished in two levels of altitudes, ranging of 800 to $1000 \mathrm{~m}$ and 600 to $800 \mathrm{~m}$. The São Franciscana depression develops along the drainage of the São Francisco River, where the prevailing forms of relief flattened with altitudes around $500 \mathrm{~m}$ (IGA, 2016). The Espinhaço Range is a large hydrographic splitter 
interposed between the basins of east-central Brazilian and of São Francisco River, and it constitutes, in Minas Gerais State, a set of highlands, with predominance of ridges, peaks, valleys embedded and to a lesser extent the forms slightly wavy (Sodré et al., 2007).

The climate of the region is Cwa, mesothermal tropical type, according to the classification of Köppen (Köppen and Geiger, 1936), presenting dry winters and mild summers with the average coldest month below $19^{\circ} \mathrm{C}$. The predominant vegetation type is cerrado of medium size, with patches of evergreen forests and subcaducifólias (Romano and Soares, 2007). The soils present in the basin are: Red Latosols; Red Yellow Latosols; Red Argisol and Red Yellow Argisols (IBGE, 2001).

\subsection{Obtaining and processing of data}

This study used five DEMs, three generated from the data of the SRTM and two others obtained from the topographic maps (CT).

The SRTM data were obtained from the Brazilian Agricultural Research Corporation (EMBRAPA), with a spatial resolution of $90 \times 90 \mathrm{~m}$ and WGS84 reference ellipsoid. The topographical maps used were the sheets Para de Minas (042533) and Pompeu (042495), made available by the Brazilian Institute of Geography and Statistics (IBGE), in vector format on a scale of 1:100,000, represented by contour lines equally spaced of $50 \mathrm{~m}$, altitude data and hydrography. The processing of data and the obtaining of the morphometric characteristics were performed using ArcGIS ${ }^{\circledR} 9.3$ (ESRI, 2008).

\subsubsection{SRTM-DEMs}

The SRTM DEMs were composed of one elaborated from the original matrix (SRTM-O) and two from the refinement of the original data. To generate the DEMs refined, SRTM data have been modified for the vector format (level curves with equidistance of $20 \mathrm{~m}$ ) and, subsequently, the level curves were interpolated by means of the interpolator Top To Raster with and without the support of the mapped hydrography, generating, respectively, the SRTMTRH and SRTM-TR DEMs, both with a spatial resolution of $10 \times 10 \mathrm{~m}$.

For the delineation of the basin and, subsequently, obtaining the morphometric characteristics, the data of the DEMs were processed following the steps: fill of the spurious depressions (fill sinks); direction of flow (flow direction); accumulated flow (flow accumulation) and delineation of basins (watershed). It should be emphasized that the hydrography was generated from the accumulated flow, using the Raster Calculator tool of the extension Spatial Analyst of ArcGIS ${ }^{\circledR}$ 9.3, using a value of 500 (a value that provided a more representative hydrography) as the minimum number of cells for the generation of flow.

\subsubsection{CT-DEMs}

The preparation of the DEMs from topographic maps was performed by means of interpolation of the level curves using the interpolator Top To Raster with and without the support from mapped hydrography, generating, respectively the CT-TRH and CT-TR DEMs, both with a spatial resolution of $10 \times 10 \mathrm{~m}$.

For the delineation of the basin and, subsequently, the obtaining of morphometric characteristics from CT-DEMs, their data were processed by following the same steps described previously for the SRTM-DEMs.

\subsection{Morphometry of the river basin}

From each DEM (obtained from SRTM data or topographic maps) the following morphometric characteristics of the basin were obtained: drainage area; perimeter; compactness coefficient; form factor; circularity index; slope; altitude; length of the main river, density of drainage and the order of water courses. 
The drainage area of a basin is defined as the flat area bounded by the topographic divider, which in turn defines the perimeter of the same. The compactness coefficient $\left(\mathrm{K}_{\mathrm{c}}\right)$, the form factor $(F)$, the circularity index (IC) and the density of drainage $\left(D_{d}\right)$ were obtained with the Equation 1, 2, 3 and 4, respectively.

$$
\begin{aligned}
& K_{C}=0,28 \cdot \frac{P}{\sqrt{A}} \\
& F=\frac{A}{L^{2}} \\
& \mathrm{IC}=12,57 \cdot \frac{A}{P^{2}} \\
& D_{d}=\frac{L_{t}}{A}
\end{aligned}
$$

In that:

$$
\begin{aligned}
& \mathrm{K}_{\mathrm{c}} \text { - compactness coefficient (dimensionless); } \\
& \mathrm{P} \text { - perimeter of the basin }(\mathrm{km}) \text {; } \\
& \text { A - area of the basin }\left(\mathrm{km}^{2}\right) \text {; } \\
& \mathrm{F} \text { - form factor (dimensionless); } \\
& \mathrm{L} \text { - shaft length of the basin }(\mathrm{km}) \text {; } \\
& \mathrm{IC} \text { - circularity index (dimensionless); } \\
& \mathrm{D}_{\mathrm{d}} \text { - density of drainage }\left(\mathrm{km} \mathrm{km}^{-2}\right) \text {; } \\
& \mathrm{L}_{\mathrm{t}} \text { - total length of water courses }(\mathrm{km})
\end{aligned}
$$

The compactness coefficient relates the form of the basin to a circle and closer values to 1 is indicative of the potential for flood flows. The form factor $(\mathrm{F})$ relates the shape of the basin to a rectangle. A narrow and long basin (small value of $\mathrm{F}$ ) is less prone to flooding than another with the same area, but with larger value of $F$. This is due to the less occurrence of intense rainfall covering at the same time the entire extension of a basin with narrow and long formato (Oliveira et al., 2010). According to Schumm (1956), the circularity index (IC) lower than 0.51, indicates that the basin tends to be more elongated favoring runoff; IC equal to 0.51 indicates a moderate level of runoff and IC greater than 0.51 indicates that the basin tends to be more circular, favoring the occurrence of flooding.

To obtain data of slope, we used the function slope available in extension Spatial Analyst of ArcGIS ${ }^{\circledR}$ 9.3. The hydrographic network was ordered according to Strahler (1957).

\subsection{Performance evaluation of DEMs}

The assessment of DEMs was performed in a quantitative and qualitative form. The quantitative evaluation consisted in determining the percentage errors between the values of the morphometric characteristics determined with the DEMs and those obtained by means of topographic maps, called reference (REF), as Oliveira et al. (2010). The qualitative evaluation consisted in comparing the mapped hydrography with the numeric hydrography and in the comparison between the delineation of the basin obtained with the DEMs and those bounded manually in topographic maps (REF), as with Chagas et al. (2010) and Cecílio et al. (2013). It should be emphasized that, due to the fact that the work focuses on the determination and evaluation of the morphometric characteristics of the basin obtained from different DEMs, the evaluation methodology described is sufficient and no other statistical measures are necessary, since the vertical accuracy of DEMs was not evaluated. 


\section{RESULTS AND DISCUSSION}

Table 1 shows the results of the morphometric characterization of the Peixe River Basin, obtained from DEMs evaluated and of reference (REF).

Table 1. Results of the morphometric characterization of the Peixe River Basin.

\begin{tabular}{|c|c|c|c|c|c|c|c|c|c|c|c|}
\hline \multirow{2}{*}{$\begin{array}{l}\text { Morphometric } \\
\text { characteristic }\end{array}$} & \multirow{2}{*}{ REF } & \multicolumn{2}{|c|}{ SRTM-O } & \multicolumn{2}{|c|}{ SRTM-TR } & \multicolumn{2}{|c|}{ SRTM-TRH } & \multicolumn{2}{|c|}{ CT-TR } & \multicolumn{2}{|c|}{ CT-TRH } \\
\hline & & Value & DIF (\%) & Value & DIF $(\%)$ & Value & DIF (\%) & Value & DIF $(\%)$ & Value & $\operatorname{DIF}(\%)$ \\
\hline $\mathrm{A}\left(\mathrm{km}^{2}\right)$ & 578.81 & 683.80 & 18.14 & 685.60 & 18.45 & 581.02 & 0.38 & 732.99 & 26.64 & 572.35 & 1.12 \\
\hline $\mathrm{P}(\mathrm{km})$ & 141.44 & 134.33 & 5.03 & 148.23 & 4.80 & 149.46 & 5.67 & 159.90 & 13.05 & 158.14 & 11.81 \\
\hline $\mathrm{L}(\mathrm{Km})$ & 80.05 & 58.62 & 26.77 & 61.74 & 22.87 & 85.71 & 7.07 & 52.53 & 34.38 & 75.82 & 5.28 \\
\hline $\mathrm{L}_{\mathrm{t}}(\mathrm{km})$ & 801.24 & 250.18 & 68.77 & 1502.96 & 87.58 & 1.354 .80 & 69.09 & 1.671 .81 & 108.65 & 1.197 .38 & 49.44 \\
\hline $\mathrm{K}_{\mathrm{c}}$ & 1.65 & 1.44 & 12.73 & 1.59 & 3.64 & 1.74 & 5.45 & 1.65 & 0.00 & 1.85 & 12.12 \\
\hline $\mathrm{F}$ & 0.09 & 0.20 & 122.22 & 0.18 & 100.00 & 0.08 & 11.11 & 0.27 & 200.00 & 0.10 & 11.11 \\
\hline IC & 0.36 & 0.48 & 33.33 & 0.39 & 8.33 & 0.33 & 8.33 & 0.36 & 0.00 & 0.29 & 19.44 \\
\hline $\mathrm{D}_{\mathrm{d}}\left(\mathrm{km} \mathrm{km}^{-2}\right)$ & 1.38 & 0.37 & 73.19 & 2.19 & 58.70 & 2.33 & 68.84 & 2.28 & 65.22 & 2.09 & 51.45 \\
\hline Order & 6 & 4 & - & 7 & - & 7 & - & 7 & - & 7 & - \\
\hline $\mathrm{A}_{\max }(\mathrm{m})$ & 1200 & 1214 & 1.17 & 1218 & 1.50 & 1215 & 1.25 & 1225 & 2.08 & 1223 & 1.92 \\
\hline $\mathrm{A}_{\min }(\mathrm{m})$ & 600 & 611 & 1.83 & 610 & 1.67 & 601 & 0.17 & 579 & 3.50 & 593 & 1.17 \\
\hline Average slope (\%) & 7.52 & 7.15 & 4.92 & 9.05 & 20.35 & 7.96 & 5.85 & 5.14 & 31.25 & 7.52 & 0.00 \\
\hline
\end{tabular}

A - drainage area; $\mathrm{P}$ - perimeter; $\mathrm{L}$ - length of the main river; $\mathrm{L}_{\mathrm{t}}$ - total length of water courses; $\mathrm{K}_{\mathrm{c}}$ - compactness coefficient; $\mathrm{F}$ - form factor; IC - circularity index; $D_{d}$ - density of drainage; $A_{\max }$ - maximum altitude, $A_{\min }$ - minimum altitude. 
Based on values obtained for the morphometric characteristics $K_{c}, F$ and IC (Table 1), the Peixe River Basin is classified as elongated trend and of low susceptibility to the occurrence of floods in normal conditions of precipitation, once it presented $\mathrm{K}_{\mathrm{c}}$ away from unity $\left(\mathrm{K}_{\mathrm{c}}\right.$ greater than 1.4), small values of $F$ (ranging from 0.08 to 0.27 ) and values of IC smaller than 0.51 .

With regard to the differences in estimates of the morphometric characteristics mentioned above, between the DEMs and the REF, it is observed for $\mathrm{K}_{\mathrm{c}}$ that these ranged from $0 \%$ (CTTR) to $12.73 \%$ (SRTM-O). How much to index F, the differences were of $11.11 \%$ (SRTMTRH and CT-TRH) to 200\% (CT-TR) and for IC of 0\% (CT-RT) to 33.33\% (SRTM-O). Both the differences are in absolute values.

These three indexes lead to the same classification of the shape of the basin, which is elongated trend. However, there were differences between the values obtained from DEMs and the REF (Table 1), which in some cases were significant. Analyses of the performance of the models based on these indices are not advisable, since they involve other morphometric characteristics in their determination and wrong conclusions can made. This is evident in the present study, when we observe differences of $0 \%$ in $\mathrm{K}_{\mathrm{c}}$ and IC with the CT-TR in comparison to the REF; however, this does not depict the performance of the model, since the variables involved in determining these indices, which is the drainage area and the perimeter of the basin, were not properly estimated (Table 1).

With respect to the drainage area, the models in the study that had the support of the mapped hydrographic at the time of their generation (SRTM-TRH and CT-TRH) showed small differences in estimates in relation to those calculated from the delineation of reference (REF), of 0.38 and $1.12 \%$, respectively, in absolute values (Table 1). For the models that did not use the mapped hydrographic as support at the time of their generation (SRTM-O, SRTM-TR and CT-TR), overestimates of greater magnitude in the drainage area are observed, of 104.99 (SRTM-O), 106.79 (SRTM-TR) and $154.18 \mathrm{~km}^{2}$ (CT-TR) in relation to the REF, which resulted in percentage differences of $18.14,18.45$ and 26.64, respectively (Table 1). The poor performance of these models in the determination of the drainage area becomes obvious when one observes the delineation of the Peixe River Basin obtained from different DEMs compared to that obtained manually (REF) (Figure 2).
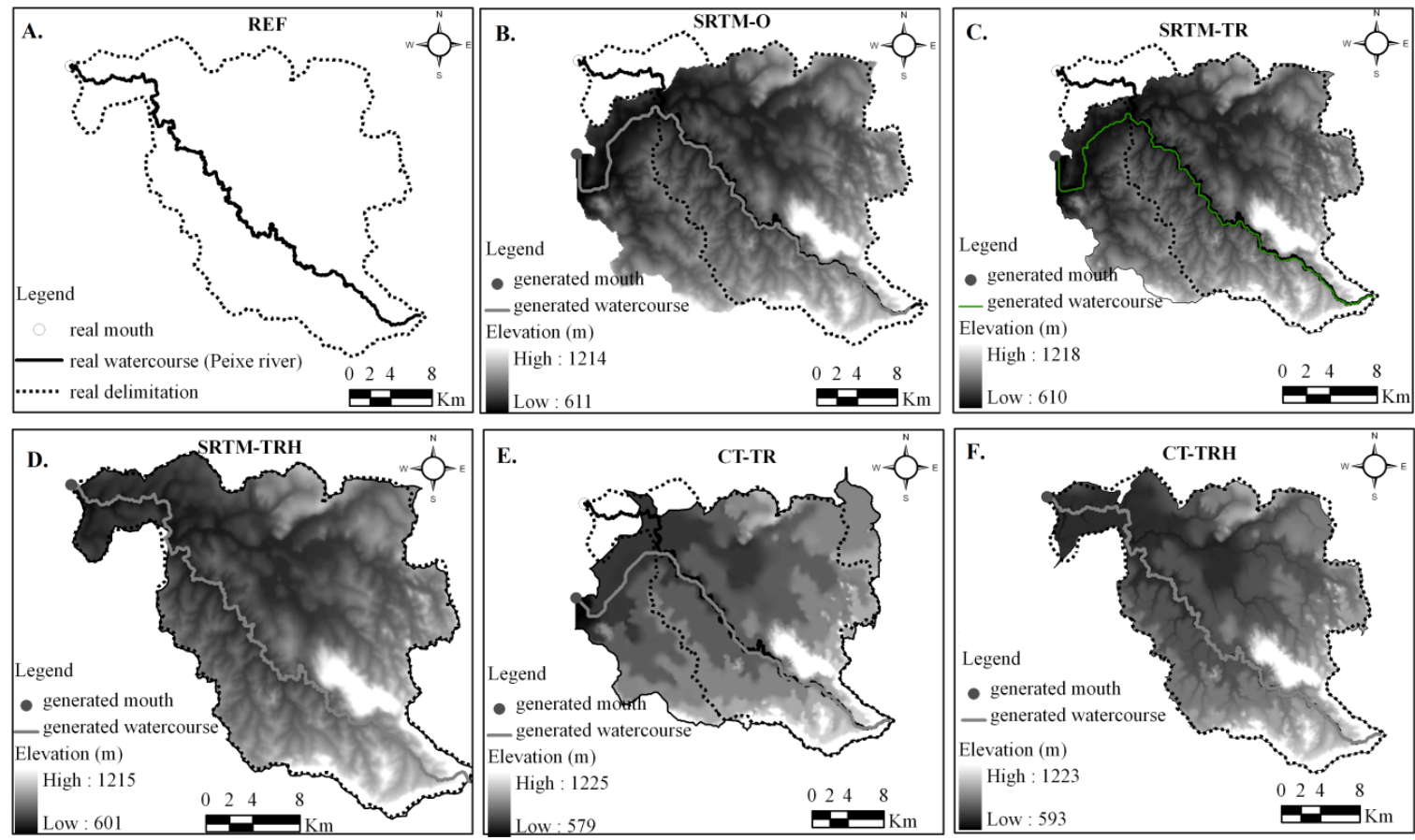

Figure 2. Delineation of the Peixe River Basin (A) manual; (B), (C) and (D) from SRTM data; and (E) and (F) from topographical maps. 
It turns out that the delineation of the basin using the DEMs (SRTM and topographic maps) that had the mapped hydrography as support at the time of their generation (Figures 2D and 2F) proved to be compatible with the manual delineation obtained from topographic maps (Figure 2A). By means of this qualitative analysis and, also, in the quantitative analysis shown in Table 1, the SRTM-TRH and CT-TRH DEMs showed great performance in the delineation of the basin and in the determination of the drainage area, important attributes for hydrologic studies. On the other hand, the delineation obtained with the DEMs generated from SRTM data and topographic maps that did not have the support of the mapped hydrographic (Figures $2 \mathrm{~B}, 2 \mathrm{C}$ and $2 \mathrm{E}$ ) was not compatible with the manual delineation, and so had the biggest mistakes in the estimation of the drainage area (Table 1).

This is not compatible with SRTM-O, SRTM-RT, and CT-RT DEMs on the delineation of the basin are mainly associated with a deviation of the main water course, the Peixe River, to a nearby basin with consequent generation of a mouth entirely off the actual location, as can be seen in Figures 2B, 2C and 2E. Alcaraz et al. (2009) also had problems similar to those of the study to delineate a watershed with greater variation of reliefs with the SRTM DEM, which led to an error of joining in the drainage network and generation of the mouth outside of location, greatly increasing the drainage area of the basin.

This fact also interfered directly in the characteristics of the drainage network, in particular, on the length of the main river (L), for the which differences were observed in estimates of 26.77, 22.87 and $34.38 \%$ in comparison to the real (REF) with the use of SRTM-O, SRTM-TR, CT-RT DEMs, respectively (Table 1). In the face of these analyses (qualitative and quantitative), these models are inadequate to determine the main morphometric characteristics of the basin used in hydrological studies, which, if they are used for this purpose, will compromise the output results.

It is interesting to note that the Peixe River Basin is inserted in a transition region between the reliefs São Francisco plateau, São Franciscana depression and Espinhaço Range, which have distinct characteristics and striking geology and topography. The São Franciscana depression is a region that develops along the banks of the São Francisco River with predominance of extensive low-lying areas of plan relief. It is in this region that the biggest problems occurred with the DEMs, especially those that did not have the support of the mapped hydrography at the time of their generation (SRTM-O, SRTM-TR and CT-TR), because they failed in adequately represent the course of the main river, in addition to the generation of many tributaries watercourses (Figure 3).

As can be seen in Figure 3, in the region of São Franciscana depression courses of tributaries water were generated in excess for all DEMs evaluated, except for the SRTM-O. This review helps explain the overestimates found in the comparison of the total length of water courses (Lt) obtained with the DEMs and the REF, which ranged from $49.44 \%$ (CT-TRH) to $108.65 \%$ (CT-TR), with the exception of the SRTM-O what underestimated at $68.77 \%$. These overestimates are associated with the spatial resolution used, which was $10 \mathrm{x} 10 \mathrm{~m}$ for all DEMs, except for the SRTM-O $(90 \times 90 \mathrm{~m})$, which allowed the formation of many rectilinear watercourses in flat areas, due to the nature of this region that makes it difficult to represent its drainage system. This is easily seen, because the reliefs of the Sao Francisco Plateau and the Espinhaço Range have areas with very steep slopes and the hydrography generated represented the actual area well in DEMs SRTM-TRH and CT-TRH (Figure 3C and 3E). The generation of many rectilinear watercourses in flat areas with the use of DEMs is also highlighted by Seyler et al. (2009) and Cecílio et al. (2013).

In the region of the São Franciscana Depression, the SRTM-TRH and CT-TRH DEMs have provided the formation of tributaries channels tin relation to hydrography of reference (REF); the main water courses were well represented (Figures 3C and 3E), as can be verified 
by the small difference between the length of the main river obtained with the DEMs in relation to the REF, which was 7.07 and $5.28 \%$ for the SRTM-TRH and CT-TRH, respectively.

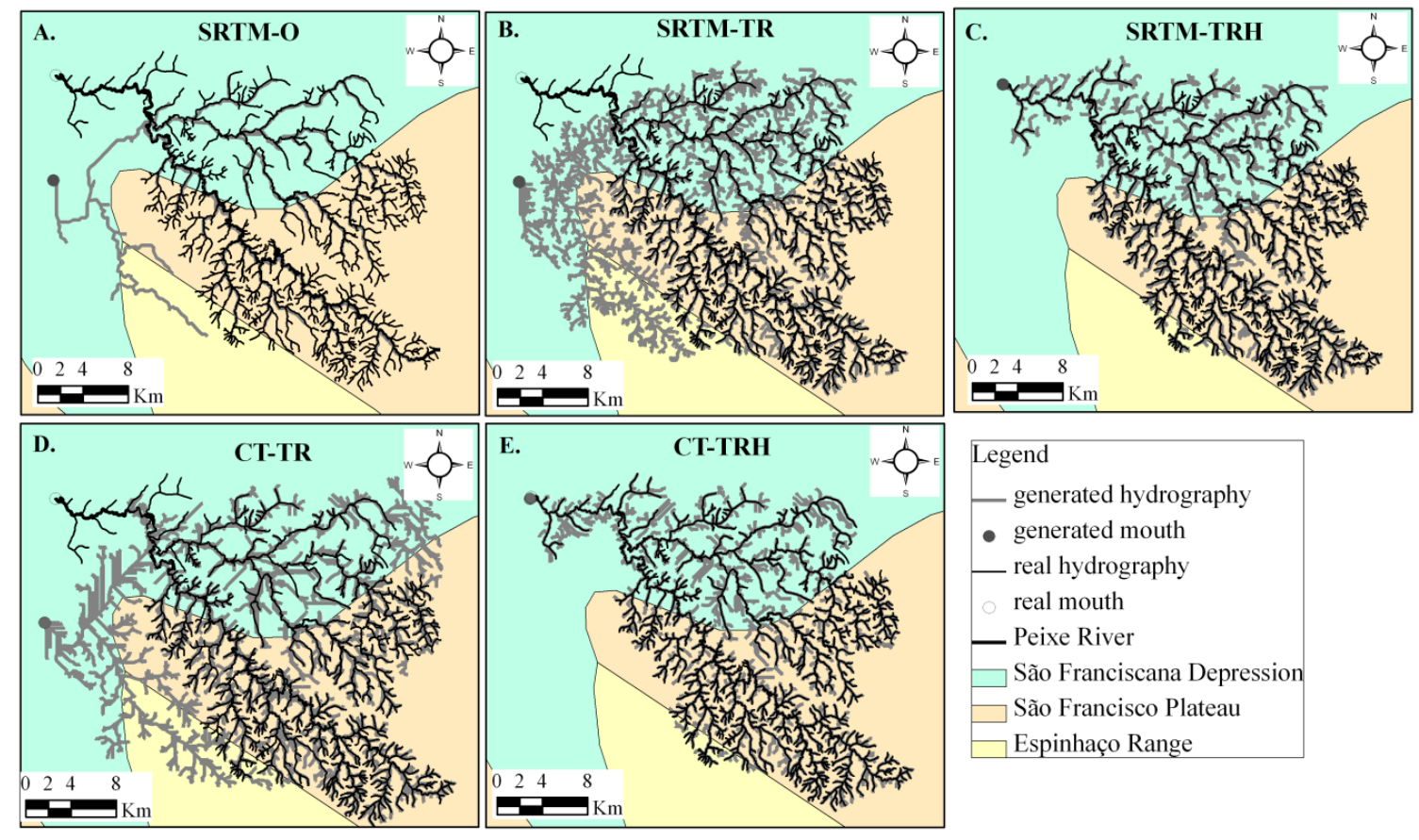

Figure 3. Mapped hydrography of the Peixe River Basin and those obtained by means of the DEMs: SRTM-O (A); SRTM-TR (B); SRTM-TRH (C); CT-TR (D) and CT-TRH (E).

The biggest problem with the representativeness of the hydrography in the region of the São Franciscana depression was the diversion of the main river (Peixe river) to a nearby basin, as previously discussed. However, it is worth noting that this happened with those models that did not have the support of the mapped hydrography during their generation (Figures 3A, 3B and 3D), which allows us to conclude that for the generation of DEMs for a region or even for other regions with similar characteristics, it is necessary to use the mapped hydrography as support, either from SRTM data or topographical maps. Some authors, such as Pires et al. (2005) and Cecílio et al. (2013) also suggest that, in order to force the location of the drainage network of a basin, which also has been observed in studies of hydrologic modeling (Pereira et al. 2016a; 2016b).

Comparing the values of $\mathrm{D}_{\mathrm{d}}$ obtained by methods in the present study, we observed significant variation in relation to the reference being of $51.45 \%$ (CT-TRH) to $73.19 \%$ (SRTM$\mathrm{O})$, which is explained by the difference between the total length of watercourses obtained with the DEMs and reference, which also explains the difference between the order of the basin obtained by reference and by DEMs.

Finally, analyzing the characteristics related to relief, good estimates were obtained of the minimum and maximum altitudes through all DEMs in comparison with the REF, with maximum differences of 2.08 and 3.50\%, respectively, for the CT-TR (Table 1). With respect to the average slope of the basin, close values were obtained (differences in about $5 \%$ ) between the SRTM-O and SRTM-TRH and the reference, which in this case was the slope obtained with the CT-TRH DEM, due to the same have been derived from topographical maps. The greatest error observed in determining the average slope of the basin was with the CT-TR DEM, whose value was $31.25 \%$ (Table 1). Figure 4 shows the data of slopes obtained from different DEMs evaluated. 

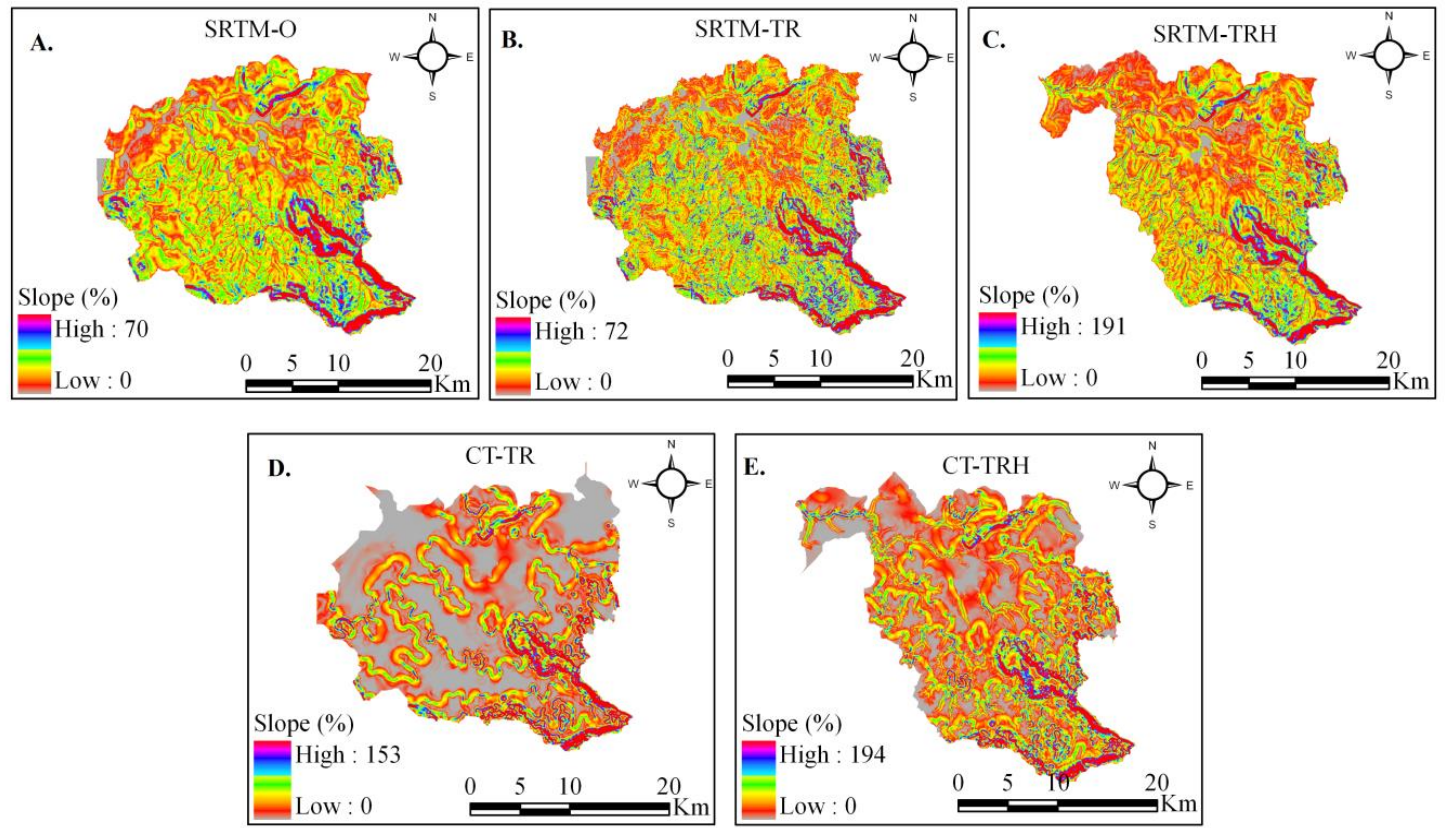

Figure 4. Slope of the Peixe River Basin determined from different DEM.

A degree of detail in the SRTM data (Figures 4A, 4B and 4C) in relation to the data of topographical maps (Figure 4D and 4E) can be observed in Figure 4. Results similar to this were obtained by Oliveira et al. (2010) when comparing DEMs from SRTM and topographical maps. They concluded that this difference is due to the greater detail from SRTM in flat areas, which can also be found in the present study when comparing Figures 4A, 4B and 4C with the Figures 4D and 4E, where areas considered of slope zero in Figure 4D and 4E are represented with details of slope in Figures 4A, 4B and 4C. However, it is important to note that the scale of the topographic maps used was 1:100,000, and it is interesting to carry out other studies using maps with different scales, for example 1:50,000, so that a better conclusion can be reached on the level of detailing of DEMs obtained from topographic maps, in comparison to remote sensing data (for example SRTM), regarding slope characterization.

\section{CONCLUSIONS}

Based on the objective of the research, which was to evaluate the performance of different DEMs for the morphometric characterization of the Peixe River Basin, which is inserted in a transition region between the Reliefs Planalto São Franscisco, São Fransciscana Depression and Serra do Espinhaço, we can conclude that:

i) In general, the DEMs that used the mapped hydrography as support at the time of their generation (SRTM-TRH and CT-TRH) presented excellent performance and are indicated for on-site study, and those that did not use (SRTM-O; SRTM -TR and CT-TR) presented poor performance.

ii) The DEMs, SRTM-O, SRTM-TR and CT-TR, provided the incorrect generation of hydrography in the region of the São Franciscana Depression (flat region), observed by the diversion of main river and generation of the mouth in another basin, causing significant errors in the determination of the morphometric characteristics of the basin, mainly in the drainage area and length of the main river, which varied from 18.1 to $26.6 \%$ and 26.7 to $34.4 \%$, respectively.

iii) The study was performed using 1:100,000 topographic maps and SRTM images at 90 x $90 \mathrm{~m}$ resolution, and the results make clear the importance of evaluating DEMs prior to their use in river basin studies, which is not always the case. However, further studies using 
topographic maps and SRTM (or other remote sensor) images at higher scales are recommended to provide a more solid conclusion on the performance of DEMs in this transition region between the São Francisco Plateau, São Francisco Depression and Espinhaço Range reliefs.

\section{ACKNOWLEDGEMENTS}

The authors would like to thank FAPEMIG by the financial support to the research project "Generation of hydrographically conditioned digital elevation model for environmental studies in the Pará river basin - MG" performed by the program PROBIC, from which originated the work.

\section{REFERENCES}

ABDULKAREEM, J. H.; PRADHAN, B.; SULAIMAN. W. N. A.; JAMIL, N. R. Quantification of Runoff as Influenced by Morphometric Characteristics in a Rural Complex Catchment. Earth Systems and Environment, v. 2, p. 1-18, 2018. https://doi.org/10.1007/s41748-018-0043-0

AHER, P. D.; ADINARAYANA, J.; GORANTIWAR, S. D. Quantification of morphometric characterization and prioritization for management planning in semi-arid tropics of India: a remote sensing and GIS approach. Journal of Hydrology, v. 511, p. 850-860, 2014.

ALCARAZ, S. A.; SANNIER, C.; VITORINO, A. C. T.; DANIEL, O. Comparison of methodologies for automatic generation of limits and drainage networks for hydrographic basins. Revista Brasileira de Engenharia Agrícola e Ambiental, v. 13, n. 4, p. 369375, 2009. http://dx.doi.org/10.1590/S1415-43662009000400001

AMERI, A. A.; POURGHASEMI, H. R.; CERDA, A. Erodibility prioritization of subwatersheds using morphometric parameters analysis and its mapping: A comparison among TOPSIS, VIKOR, SAW, and CF multi-criteria decision making models. Science of The Total Environment, v. 613, p. 1385-1400, 2018.

ARIZA-VILLAVERDE, A. B.; JIMÉNEZ-HORNERO, F. J.; DE RAVÉ, E. Gutiérrez. Influence of DEM resolution on drainage network extraction: A multifractal analysis. Geomorphology, v. 241, p. 243-254, 2015.

BASSIOUNI, M.; VOGEL, R. M.; ARCHFIELD, S.A. Panel regressions to estimate low-flow response to rainfall variability in ungauged basins. Water Resources Research, v. 52, n. 12, p. 9470-9494, 2016.

CECÍLIO, R. A.; COUTINHO, L. M.; XAVIER, A. C.; MOREIRA, M. C.; ZANETTI, S. S.; GARCIA, G. O. Delimitação de bacia hidrográfica em região montanhosa a partir de diferentes modelos digitais de elevação. Semina: Ciências Agrárias, v. 34, n. 5, p. 2007 2024, 2013. http://dx.doi.org/10.5433/1679-0359.2013v34n5p2007

CHAGAS, C. S.; FERNANDES FILHO, E. I.; ROCHA, M. F.; CARVALHO Jr., W.; SOUZA NETO, N. C. Avaliação de modelos digitais de elevação para aplicação de um mapeamento digital de solos. Revista Brasileira de Engenharia Agrícola e Ambiental, v. 14, n. 2, p. 218-226, 2010.

CHAPLOT, V.; DARBOUX, F.; BOURENNANE, H.; LEGUÉDOIS, S.; SILVERA, N.; PHACHOMPHON, K. Accuracy of interpolation techniques for the derivation of digital elevation models in relation to landform types and data density. Geomorphology, v. 77, n. 1-2, p. 126-141, 2006. http://dx.doi.org/10.1016/j.geomorph.2005.12.010 
CUNHA, E. R.; BACANI, V. M. Morphometric Characterization of a Watershed through SRTM Data and Geoprocessing Technique. Journal of Geographic Information System, v. 8, p. 238-247, 2016. http://dx.doi.org/10.4236/jgis.2016.82021

DAS, S.; PATEL, P. P.; SENGUPTA, S. Evaluation of different digital elevation models for analyzing drainage morphometric parameters in a mountainous terrain: a case study of the Supin-Upper Tons Basin, Indian Himalayas. SpringerPlus, v. 5, n. 1, p. 1544, 2016.

ENVIRONMENTAL SYSTEMS RESEARCH INSTITUTE - ESRI. ArcGIS Professional GIS for the desktop. version 9.3. Software. Redlands, 2008.

ESPER ANGILLIERI, M. Y. Morphometric analysis of Colangüi river basin and flash flood hazard, San Juan, Argentina. Environmental Geology, v. 55, n. 1, p. 107-111, 2008. http://dx.doi.org/10.1007/s00254-007-0969-2

FIOREZE, A. P.; OlIVEIRA, L. F. C. de; FRANCO, A. P. B. Avaliação do desempenho de equações de regionalização de vazões na bacia hidrográfica do Ribeirão Santa Bárbara, Goiás, Brasil. Revista Ambiente \& Água, v. 3, n. 2, p. 62-76, 2008. http://dx.doi.org/10.4136/ambi-agua.53

GEBREHIWOT, S. G.; IISTEDT, U.; GÄRDENAS, A. I.; BISHOP, K. Hydrological characterization of watersheds in the Blue Nile Basin, Ethiopia. Hydrology and Earth System Sciences, v. 15, n. 1, p. 11-20, 2011. http://dx.doi.org/10.5194/hess-15-11-2011

INSTITUTO BRASILEIRO DE GEOGRAFIA E ESTATÍSTICA - IBGE. Mapa de Solos do Brasil. 2001. Disponível em: ftp://geoftp.ibge.gov.br/mapas_tematicos/mapas_murais/solos.pdf. Acesso em: 17 jul. de 2015 .

INSTITUTO DE GEOCIÊNCIAS APLICADAS. Atlas digital de minas gerais: Geomorfologia. Disponível em: http://www.iga.mg.gov.br/mapserv_iga/atlas/TutorialPDF/7-Geomorfologia.pdf. Acesso em: 20 de maio de 2016.

KÖPPEN, W.; GEIGER, R. Handbuch der klimatologie. Berlin: Gebrüder Borntraeger, 1936.

MERAJ, G.; ROMSHOO, S. A.; YOUSUF, A. R.; ALTAF, S.; ALTAF, F. Assessing the influence of watershed characteristics on the flood vulnerability of Jhelum basin in Kashmir Himalaya. Natural Hazards, v. 77, n. 1, p. 153-175, 2015.

MUDASHIRU, R. B.; SALAMI, A. W.; BILEWU, S. O. Evaluation of Methods of Peak Runoff Determination using Catchment Characteristics for Jere Sub-basin, Gurara River Basin, North Central Nigeria. The Journal of Engineering Research [TJER], v. 15, n. 1, p. 26-41, 2018.

OLIVEIRA, P. T. S.; ALVES SOBRINHO, T.; STEFFEN, J. L.; RODRIGUES, D. B. B. Caracterização morfométrica de bacias hidrográficas através de dados SRTM. Revista Brasileira de Engenharia Agrícola e Ambiental, v. 14, n. 8, p. 819-825, 2010.

PEREIRA, D. R.; MARTINEZ, M. A.; SILVA, D. D. da; PRUSKI, F. F. Hydrological simulation in a basin of typical tropical climate and soil using the SWAT Model Part II: Simulation of hydrological variables and soil use scenarios. Journal of Hydrology: Regional Studies, v. 5, p. 149-163, 2016a. http://dx.doi.org/10.1016/j.ejrh.2015.11.008 
PEREIRA, D. R.; MARTINEZ, M. A.; PRUSKI, F. F.; SILVA, D. D. Hydrological simulation in a basin of typical tropical climate and soil using the SWAT model part I: Calibration and validation tests. Journal of Hydrology: Regional Studies, v. 7, p. 14-37, 2006b. http://dx.doi.org/10.1016/j.ejrh.2016.05.002

PIRES, J. M.; NASCIMENTO, M. C.; SANTANA, R. M.; RIBEIRO, C. A. A. S. Análise da exatidão de diferentes métodos de interpolação para geração de modelos digitais de elevação e obtenção de características morfométricas em bacias hidrográficas. Revista Brasileira de Recursos Hídricos v. 10, n. 2, p. 39-47, 2005.

ROMAnO, A. W.; SOARES, A. C. P. Geologia da folha Pará de Minas SE.23-Z-C-IV: escala 1:100.000. Brasília; Belo Horizonte: CPRM/UFMG. 2007. Disponível em: http://rigeo.cprm.gov.br/xmlui/bitstream/handle/doc/10765/nota.pdf?sequence $=1$.

Acesso em: 10 de Nov. de 2016.

SEYLER, F.; MUlLER, F.; COCHONNEAU, G.; GUIMARÃES, L.; GUYOT, J. L. Watershed delineation for the Amazon sub-basin system using GTOPO30 DEM and a drainage network extracted from JERS SAR images. Hydrological Processes, v. 23, n. 22, p. 3173-3185, 2009. http://dx.doi.org/10.1002/hyp.7397

SCHUMM, S. A. Evolution of drainage systems and slopes in badlands at Perth Amboy, New Jersey. Geological society of America bulletin, v. 67, n. 5, p. 597-646, 1956. http://dx.doi.org/10.1130/0016-7606(1956)67[597:EODSAS]2.0.CO;2

SILVA, J. M. A.; PRUSKI, F. F.; SILVA, D. D. da; CECÍLIO, R. A. Metodologia para obtenção do hidrograma de escoamento superficial em encostas e canais. Parte I: desenvolvimento e avaliação. Engenharia Agrícola, v. 26, n. 3, p. 695-703, 2006. http://dx.doi.org/10.1590/S0100-69162006000300005

SODRÉ, R. V. R.; CARVALHO JÚNIOR, A. O.; MACHADO, W. P.; OLIVEIRA, S. N.; GOMES, R. A. T.; GUIMARÃES, R. F. Classificação de bacias de drenagem do Alto Jequitaí (Minas Gerais) a partir da análise de principais componentes e análise de grupos. Revista Brasileira de Geomorfologia, v. 8, n. 2, p. 73-86, 2007.

STRAHLER, A. N. Quantitative analysis of watershed geomorphology. Eos, Transactions

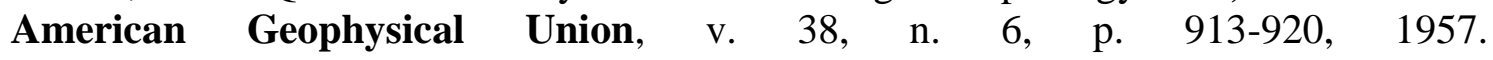
http://dx.doi.org/10.1029/TR038i006p00913

WOODROW, K.; LINDSAY, J. B.; BERG, A. A. Evaluating DEM conditioning techniques, elevation source data, and grid resolution for field-scale hydrological parameter extraction. Journal of Hydrology, v. 540, p. 1022-1029, 2016. 


\begin{tabular}{|} 
Ambiente \& Água - An Interdisciplinary Journal of Applied Science \\
ISSN 1980-993X - doi:10.4136/1980-993X \\
www.ambi-agua.net \\
E-mail: ambi.agua@gmail.com
\end{tabular}

\title{
Spatial-temporal analysis of the surface water quality of the Pará River Basin through statistical techniques
}

\author{
ARTICLES doi:10.4136/ambi-agua.2322
}

Received: 24 Aug. 2018; Accepted: 12 Nov. 2018

\author{
Josiani Cordova de Oliveira ${ }^{*(\mathbb{D})}$; Kelly Prado Maia ${ }^{(\mathbb{D} \text {; }}$ \\ Nara Linhares Borges de Castro ${ }^{2}$; Sílvia Maria Alves Corrêa Oliveira ${ }^{1}$ \\ ${ }^{1}$ Universidade Federal de Minas Gerais (UFMG), Belo Horizonte, MG, Brasil \\ Departamento de Engenharia Sanitária e Ambiental (DESA). E-mail: josiani.oliv@gmail.com, \\ kellypradomaia@hotmail.com, silvia@desa.ufmg.br \\ ${ }^{2}$ Universidade Federal de Minas Gerais (UFMG), Belo Horizonte, MG, Brasil \\ Departamento de Engenharia de Materiais e Construção (DEMC). E-mail: linhares.nara@gmail.com \\ *Corresponding author
}

\begin{abstract}
Water quality issues are a growing concern due to the the recent intensification of urbanization and industrialization. This paper evaluates and compares the surface water quality of the ten sub-basins of the Pará River, located in the São Francisco River Basin, Minas Gerais, and evaluates the impact of seasonality and the compliance with the current limits of state legislation. The surface water quality monitoring database of the Institute of Water Management of Minas Gerais (Igam) was used, and 18 parameters were analyzed from a historical series from 2008 to 2016, totaling 16,651 observations. First, the descriptive statistics of the parameters were calculated, considering each sub-basin separately. Then, for the temporal and spatial analysis, the Kruskal-Wallis nonparametric statistical tests were applied, followed by the multiple comparison test, with an alpha level of 5\%, due to the asymmetric behavior of the data. Thus, it was possible to compare water quality of the sub-basins in rainy and dry seasons and to identify which parameters were responsible for the greater degradation. In the compliance analysis to the current limits of state legislation, it was identified that all of the sub-basins were out of the specified range for at least one of the evaluated parameters. Finally, the seasonality analysis exposed significant differences in the parameters of dissolved oxygen, turbidity, total suspended solids, total solids and water temperature, where it was shown that there was a worsening of water quality in the rainy season for most sub-basins.
\end{abstract}

Keywords: non-parametric tests, Pará River Hydrographic Basin, surface water, water quality.

\section{Análise espaço-temporal da qualidade das águas superficiais da Bacia Hidrográfica do rio Pará por meio de técnicas estatísticas}

\section{RESUMO}

As questões de qualidade da água são uma crescente preocupação com a recente intensificação da urbanização e industrialização de grande parte das bacias hidrográficas. Este trabalho propõe avaliar e comparar a qualidade das águas superficiais das dez sub-bacias do rio Pará, localizadas na Bacia do rio São Francisco, Minas Gerais, além de verificar o impacto da sazonalidade e o atendimento aos limites da legislação estadual vigente. Foi utilizado o banco 
de dados de monitoramento da qualidade das águas superficiais do Instituto Mineiro de Gestão das Águas (Igam), sendo analisados 18 parâmetros oriundos de uma série histórica de 2008 a 2016, em um total de 16.651 observações. Primeiramente, foi calculada a estatística descritiva dos parâmetros, considerando cada sub-bacia separadamente. Em seguida, para a análise espacial e temporal, foram aplicados os testes estatísticos não paramétricos de Kruskal-Wallis, seguido pelo teste de comparações múltiplas, ao nível de significância de 5\%, face ao comportamento assimétrico dos dados. Assim, foi possível comparar a qualidade da água das sub-bacias nos períodos chuvoso e seco e identificar quais parâmetros foram responsáveis pela maior degradação. $\mathrm{Na}$ análise do atendimento à legislação e ao enquadramento, identificou-se que todas as sub-bacias se mostraram fora do enquadramento para, pelo menos, um dos parâmetros avaliados. Por fim, a análise da sazonalidade apontou diferenças significativas nos parâmetros OD, turbidez, sólidos em suspensão totais, sólidos totais e temperatura da água onde foi demonstrado que houve uma piora da qualidade da água no período chuvoso para a maioria das sub-bacias.

Palavras-chave: águas superficiais, Bacia Hidrográfica do rio Pará, qualidade da água, testes não paramétricos.

\section{INTRODUCTION}

Water is a component integrated into the global system, which has been strongly altered and degraded with anthropic actions. The velocity and extension of globalization, allied with socioeconomic development, has increased the demand for water resources, reflected in the scarcity and deterioration of springs. Water became a growing worry not only regarding the available quantity but, mainly, concerning quality and restrictions in its uses (Barakat et al., 2016; Giri and Qiu et al., 2016; Zeinalzadeha and Rezaei, 2017; Delkash et al., 2018).

Ferrier et al. (2001) affirm that the properties of a water system tend to reflect the combination of geomorphological attributes, with a variation of direct and indirect influences of climatological aspects and the anthropogenic action in the basins. Hence, chemical components found in water bodies are variable and have correlations with specific characteristics of each environment, being subject to constant changes in the environmental system, caused mainly by anthropic actions (Kazi et al., 2009).

Many studies regarding water quality have been presented with the objective of evaluating the extension of impacts in quali-quantitative aspects of hydrographic basins as consequences of anthropization (Trindade et al., 2016; Pinto et al., 2017; Gebler et al., 2018). However, although there may be much data available, this information is often disorganized and scattered in different institutions and public agencies. These programs also generate extensive data matrices, which are usually difficult to interpret, and the identification of the possible causes that may influence the occurrence and the concentration of a given parameter may become a complex task (Simeonov et al., 2003).

In Minas Gerais, the state Water Management Institute (Igam), through the Project Águas de Minas, has monitored surface- and ground-water quality in the state since 1997 . The program provides a historical data series related to water quality of Minas Gerais, which is indispensable to the proper management of the available water resources (IGAM, 2010a).

The referred database available is extensive and difficult to interpret, making it impossible to obtain immediate conclusions with only a superficial analysis. In this sense, statistical methods have become an excellent exploratory interpretation tool. Studies made by Trindade et al. (2016); Christofaro et al. (2017); Costa et al. (2017); Oliveira et al. (2017) and Pinto et al. (2017); showed the use of these statistical tools to explore many objects of study involving quality of water bodies, pollution, anthropic relations, amongst others. The use of non- 
parametric tests in these studies presents positive results when aiming to find significant differences between sampling units, evaluating the behavior patterns of each studied event.

Thus, this work aims: (i) to characterize and compare the surface waters quality of the ten sub-basins of the Pará River, located in the São Francisco River Basin, Minas Gerais, regarding monitoring data of the analyzed parameters, (ii) to evaluate compliance with the standards established by the current state law for each parameter, concerning legal classification and, finally, (iii) to evaluate and compare the effect of seasonality in surface water quality of the ten sub-basins.

\section{METHODOLOGY}

\subsection{Characterization of the study area}

The Pará River Hydrographic Basin corresponds to the SF2 Water Resources Planning and Management Unit (UPRGH), located in southwestern Minas Gerais. Its main river is born in the municipality of Resende Costa and extends for $365 \mathrm{~km}$ until flowing into the São Francisco River. The basin covers approximately $12,300 \mathrm{~km}^{2}$, where 35 municipalities are located. The estimated population of the basin is 700,000 inhabitants, with $12 \%$ living in rural areas (IGAM, 2018).

The basin presents high degradation which directly affects the quality of life of the population. According to Igam reports, the main pressure sources associated with the water quality changes in the Pará River basin are: extractions of sand, clay, gravel, limestone and quartz; artisanal mining; extraction of precious stones; extraction and processing of metallic minerals; mining and processing of gold; agriculture; livestock; silviculture; diffuse charge; erosion and aggradation; release of domestic/sanitary sewer and the release of industrial effluents (IGAM, 2010a; 2010b).

\subsection{Quality evaluation of surface waters of the Pará River Basin}

Data were analyzed from 26 monitoring stations with sampling carried out every 3 months during the period from 2008 to 2016. A total of 16,651 observations from parameters total chloride (Cl-T); a chlorophyll $(\mathrm{Cl}-a)$; thermotolerant coliforms/Escherichia coli (TC/E. coli); in loco electrical conductivity (EC); biological oxygen demand (BOD); chemical oxygen demand $(\mathrm{COD})$; total phosphorus $\left(\mathrm{P}_{\mathrm{T}}\right)$; nitrate $\left(\mathrm{N}_{-} \mathrm{NO}_{3}{ }^{-}\right)$; total ammonia nitrogen $\left(\mathrm{N}_{-} \mathrm{NH}_{4}{ }^{+}\right)$; dissolved oxygen (DO); potential of hydrogen in loco $(\mathrm{pH})$; total suspended solids (TSS); total solids (TS); tensioactive substances (MBAS); sulfide $\left(\mathrm{H}_{2} \mathrm{~S}\right)$; water temperature $(\mathrm{T})$; turbidity (turb) and total zinc $\left(\mathrm{Zn}_{\mathrm{T}}\right)$ were evaluated.

The spatial arrangement of water quality monitoring stations along the Pará River Basin is shown in Figure 1. The description of sub-basins is shown in Tables 1 and 2, respectively.

Real data (raw values) from the observations in each station were organized considering each sub-basin and split into two seasons: dry and rainy, in order to analyze the impact of seasonality. It is emphasized that the delimitation of the sub-basins was established by the Land Use Plan (IGAM, 2016b; 2016c) and was made through the ottocoded (1:50.000) Igam base. Such methodology, proposed by Otto Pfafstetter is based on the grouping of direct contribution areas of each stretch of the hydrographic net that have the same code. Hence, the hydrographic basins correspond to the aggregation of the areas of hydrographic contribution, known as ottobasins (Pfafstetter, 1989).

Descriptive statistics for the raw data of each parameter were calculated for all sub-basins, showing their minimum and maximum values, average, standard deviation, geometric average and percentiles (25th, median-50th, and 75th).

In order to define the statistical analyzes to be conducted, a Shapiro-Wilk normality test was applied, with a 5\% significance. Moreover, since most parameters do not follow the Normal 
distribution, nonparametric tests were utilized to compare the median values, as well as for the analysis of seasonality.

To detect significant differences between concentrations of water quality parameters in the sub-basins, the nonparametric tests of Kruskal-Wallis were applied to compare multiple independent samples, followed by the multiple comparison test (when applicable) with an alpha level of 5\%. Thus, it was possible to identify which sub-basins were more impacted and which parameters were responsible for a worsening in water quality degradation. Box-plots were also generated to better visualize of the results. All statistical analyzes were performed with the Statistica® 13.0 software.
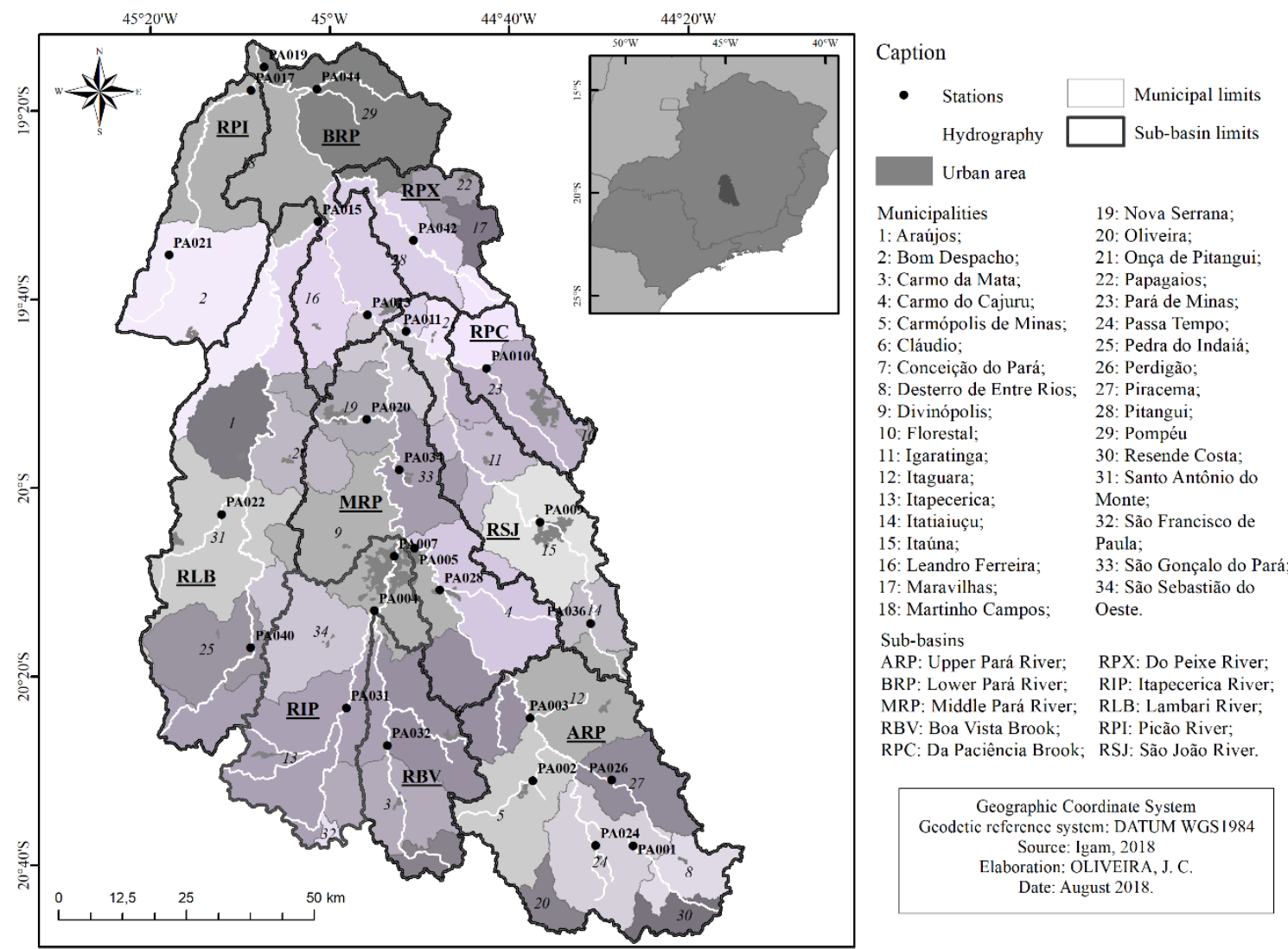

Figure 1. Pará River hydrographic basin with the locations of water quality monitoring stations, and sub-basins.

Table 1. Description of the sub-basins.

\begin{tabular}{lcc}
\hline Sub-basin & Reference code & Monitoring Stations \\
\hline Upper Pará River & ARP & PA001, PA002, PA003, PA024, PA026 \\
Lower Pará River & BRP & PA013, PA019, PA044 \\
Middle Pará River & MRP & PA005, PA020, PA028, PA034 \\
Boa Vista Brook & RBV & PA032 \\
Da Paciência Brook & RPC & PA010 \\
Do Peixe River & RPX & PA042 \\
Itapecerica River & RIP & PA004, PA007, PA031 \\
Lambari River & RLB & PA015, PA022, PA040 \\
Picão River & RPI & PA017, PA021 \\
São João River & RSJ & PA009, PA011, PA036 \\
\hline
\end{tabular}


Table 2. Description of water quality monitoring stations.

\begin{tabular}{|c|c|c|c|c|}
\hline Station & Class $^{(1)}$ & Description & $\begin{array}{l}\text { Latitude } \\
\qquad \text { (decin }\end{array}$ & $\begin{array}{l}\text { Longitude } \\
\text { al deg.) }\end{array}$ \\
\hline PA001 & 1 & Pará River, between Passa Tempo and Desterro de Entre Rios & -20.37 & -44.25 \\
\hline PA002 & 2 & Paiol Brook, downstream from Carmópolis de Minas & -20.31 & -44.37 \\
\hline PA003 & 1 & Pará River, in Pará dos Vilelas & -20.24 & -44.37 \\
\hline PA004 & 1 & Itapecerica River, upstream from Divinópolis & -20.13 & -44.54 \\
\hline PA005 & 1 & Pará River, upstream from the confluence with Itapecerica River & -20.06 & -44.5 \\
\hline PA007 & 3 & Itapecerica River, downstream from Divinópolis & -20.07 & -44.52 \\
\hline PA009 & 2 & São João River, downstream from Itaúna & -20.03 & -44.36 \\
\hline PA010 & 3 & Paciência Brook, downstream from Pará de Minas & -19.47 & -44.42 \\
\hline PA011 & 2 & São João River, upstream from the confluence with Pará River & -19.43 & -44.51 \\
\hline PA013 & 2 & Pará River, next to Pitangui & -19.41 & -44.55 \\
\hline PA015 & 1 & Lambari River, upstream from the confluence with Pará River & -19.31 & -45.01 \\
\hline PA017 & 1 & Picão River, upstream the confluence with Pará River & -19.17 & -45.08 \\
\hline PA019 & 2 & Pará River, upstream the confluence with São Francisco River & -19.15 & -45.07 \\
\hline PA020 & 2 & Fartura Brook, downstream from Nova Serrana & $-19,52$ & -44.55 \\
\hline PA021 & 1 & Picão River, downstream from the city of Bom Despacho & -19.35 & -45.17 \\
\hline PA022 & 1 & Diamante Brook near its mouth, in the Lambari River & -20.02 & -45.12 \\
\hline PA024 & 1 & Passa Tempo Brook, in Passa Tempo & -20.37 & -44.3 \\
\hline PA026 & 1 & Do Peixe River, upstream from Piracema & -20.3 & -44.28 \\
\hline PA028 & 1 & Pará River, upstream from Carmo do Cajurú & -20.1 & -44.47 \\
\hline PA031 & 2 & Itapecerica River, downstream from Itapecerica & -20.23 & -44.58 \\
\hline PA032 & 2 & Boa Vista Brook, downstream from Carmo da Mata & -20.27 & -44.53 \\
\hline PA034 & 2 & Do Pinto Creek, downstream from São Gonçalo do Pará & -19.58 & -44.52 \\
\hline PA036 & 1 & São João River, locality of São João, Itatiauçu & -20.14 & -44.3 \\
\hline PA040 & 1 & $\begin{array}{l}\text { Lambari River, under the bridge on the MG } 050 \text { highway, Pedra do } \\
\text { Indaiá }\end{array}$ & -20.16 & -45.08 \\
\hline PA042 & 1 & Do Peixe River in the locality of Rio do Peixe, in Pitangui & -19.33 & -44.5 \\
\hline PA044 & 2 & Do Salobro Creek, downstream from Pompéu & -19.17 & -45.01 \\
\hline
\end{tabular}

(1) - Ordination class, according to DN COPAM (1998).

Multivariate statistical methods were not utilized due to data heterogeneity, which had missing observations, what would result in a considerable information loss in the use of multivariate analysis, since they follow the premise that the amount of data must be the same for all stations, excluding observations that do not match this condition.

To evaluate law compliance, the results of the analyzes of all sampling points in the subbasins were compared to the limits established by the Joint Normative Deliberation COPAM/CERH n. 01/2008 (COPAM and CERH 2008). Since state law establishes more strict values than the national CONAMA Resolution n. 357/2005, in this study it was decided to compare the water quality data series with local values in order to rate violations in water quality parameters. With this, it was possible to calculate the violation percentage of each parameter, in the sub-basins, to identify the main causes of environmental degradation.

To verify the effect of seasonality in surface water quality, data were split for each basin in dry and rainy seasons. According to the definition contained in the Igam report (2016d), for the state of Minas Gerais the dry season takes place between April and September, and the rainy between October and March. In order to verify the matching of seasons, daily rainfall data, from 2008 to 2016 were obtained with the automatic surface weather stations of the National Meteorology Institute (INMET), located in the Pará River Basin coverage area and its surroundings. Hence, data from the stations Divinópolis-A564, Formiga-A524, Florestal-A535, Pompéu-A560 and Oliveira-A570 were analyzed and compared to the water quality data from the same days. From this evaluation, both seasons defined by Igam were confirmed.

The nonparametric Kruskal-Wallis test was utilized to the comparison of multiple independent samples for all sub-basins considering both seasons. Then, when a significant 
difference between the concentrations of the parameters was detected, the multiple comparison test with a 5\% significance level was applied, and finally, box-plot graphs were generated.

\section{RESULTS AND DISCUSSIONS}

All analyses proposed in the methodology were conducted, regarding the 18 chosen parameters. However, the parameters TC/E. Coli, BOD, $\mathrm{P}_{\mathrm{T}}, \mathrm{DO}$ and turbidity will be considered here, which presented a significant difference regarding seasonality.

\subsection{Descriptive analysis of database}

According to what was verified by the descriptive analysis of data, TC/E. Coli showed high maximum values, very close or same as the detection limits of the method. Such results are a characteristic from anthropized hydrographic basins. Other studies, conducted by Calazans (2015), Trindade et al. (2016); Costa et al. (2017) and Oliveira et al. (2017), also shown high concentrations of TC/E. Coli in all water bodies of Minas Gerais.

$\mathrm{P}_{\mathrm{T}}$ presented higher median values in the Da Paciência brook sub-basin, reaching 0.69 $\mathrm{mgL}^{-1}$. All maximum values were higher than the $0.15 \mathrm{mg} / \mathrm{L}$ limit in all sub-basins. These results are mainly referred to agricultural activities and the lack of treatment of sanitary sewage, or insufficient treatment in the municipalities.

DO and BOD had similar behavior to what was observed in $\mathrm{P}_{\mathrm{T}}$, showing the highest concentrations in Middle Pará River, Da Paciência Brook and São João River sub-basins, reaching $0.5 \mathrm{mg} / \mathrm{L}$ of DO and $383 \mathrm{mg} / \mathrm{L}$ of BOD in Middle Pará River. This minimum DO value is higher, also than the established limits for Class 4 water bodies. In this case, the impact of sanitary sewage release from the urban areas of Carmo do Cajuru, Divinópolis, Nova Serrana, São Gonçalo do Pará (MRP), Itaúna (RSJ) and Pará de Minas (RPC), located upstream from the stations that make up these three sub-basins.

Regarding turbidity, three high maximum values were observed, ranging from two to ten times above the maximum established concentration for Class 4 and values close to 4,000 NTU, as verified in Da Paciência Brook.

\subsection{Characterization and comparison of surface waters in the Pará River sub-basins}

In the surface water quality evaluation, the Kruskal-Wallis nonparametric test identified significant differences between the concentrations of all parameters analyzed in the sub-basins.

Figure 2 shows the box-plots and results of the multiple comparison test, after a difference indicated by the Kruskal-Wallis test $(\mathrm{p}<0,05)$, from all five water quality parameters mentioned above.

Through the observation of the box-plots and tables of the multiple comparison tests, it is possible to identify that the Da Paciência Brook sub-basin showed the highest median concentrations in four of the five parameters, differing significantly, with $\alpha=5 \%$, from all other sub-basins, at least twice.

Regarding CT/ E. coli and BOD concentrations in the Middle Pará River sub-basin, it can be seen that, by observing the box-plots in Figure 2, the differences exposed by the concentrations become evident. As an example of the multiple comparison test table interpretation, consider only the parameter BOD and the MRP sub-basin. It can be observed that the median BOD values of this sub-basin were significantly higher than the ones presented in seven of the ten analyzed sub-basins. The median BOD of São João River sub-basin did not differentiate itself significantly from the value shown by MRP, meanwhile, Da Paciência Brook sub-basin showed a significantly lower median value. 


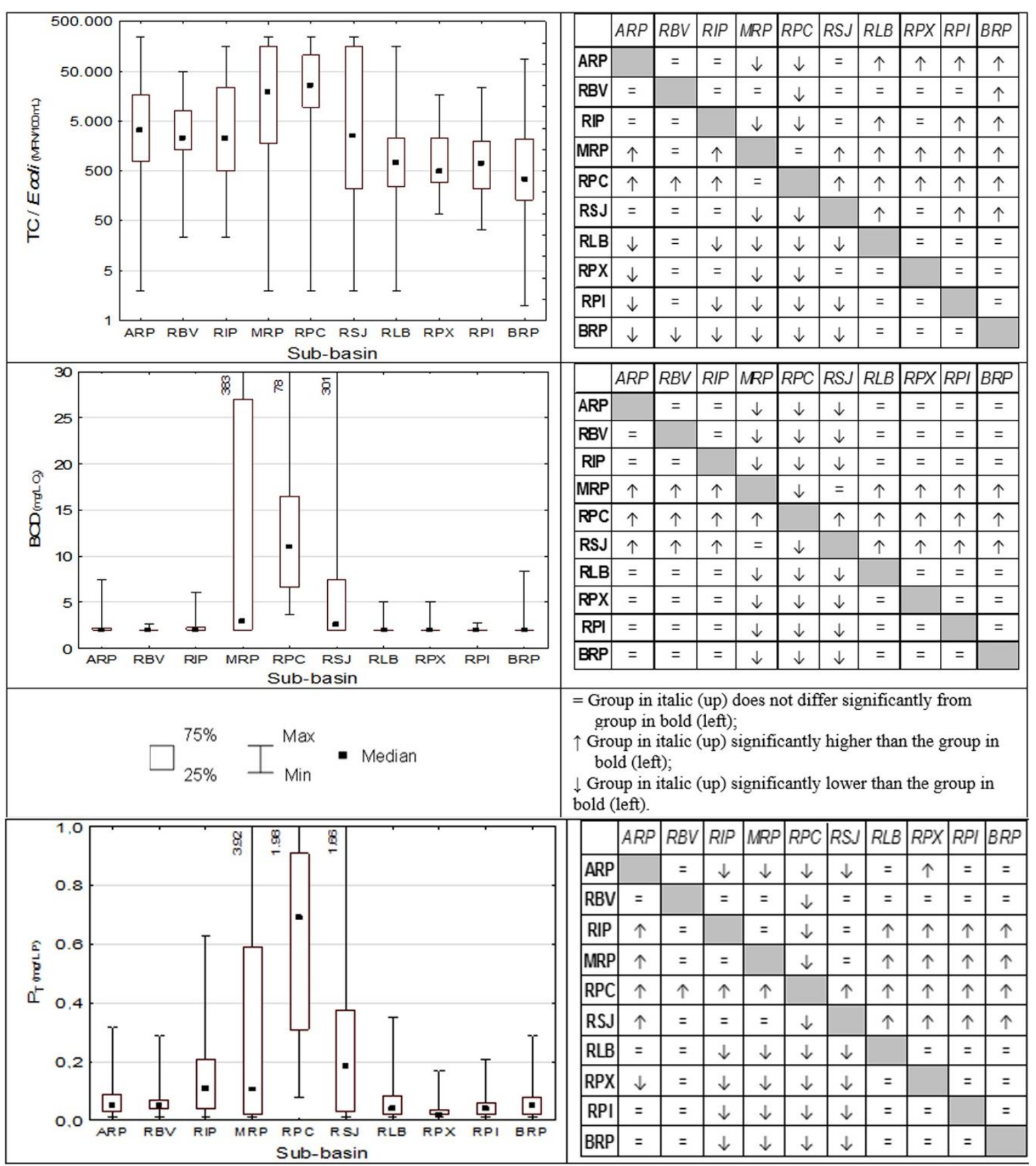

Figure 2. Box-plots and tables from the multiple comparison test of parameters TC/ E. coli, BOD, $\mathrm{P}_{\mathrm{T}}$, DO and Turbidity of the ten sub-basins.

ARP - Upper Pará River (PA001, PA002, PA003, PA024, PA026); RBV - Boa Vista Brook (PA032); RIP - Itapecerica River (PA004, PA007, PA031); MRP - Middle Pará River (PA005, PA020, PA028, PA034); RPC - Da Paciência Brook (PA010); RSJ - São João River (PA009, PA011, PA036); RLB - Lambari River (PA015, PA022, PA040); RPX - Do Peixe River (PA042); RPI - Picão River (PA017, PA021); BRP - Lower Pará River (PA013, PA019, PA044). 


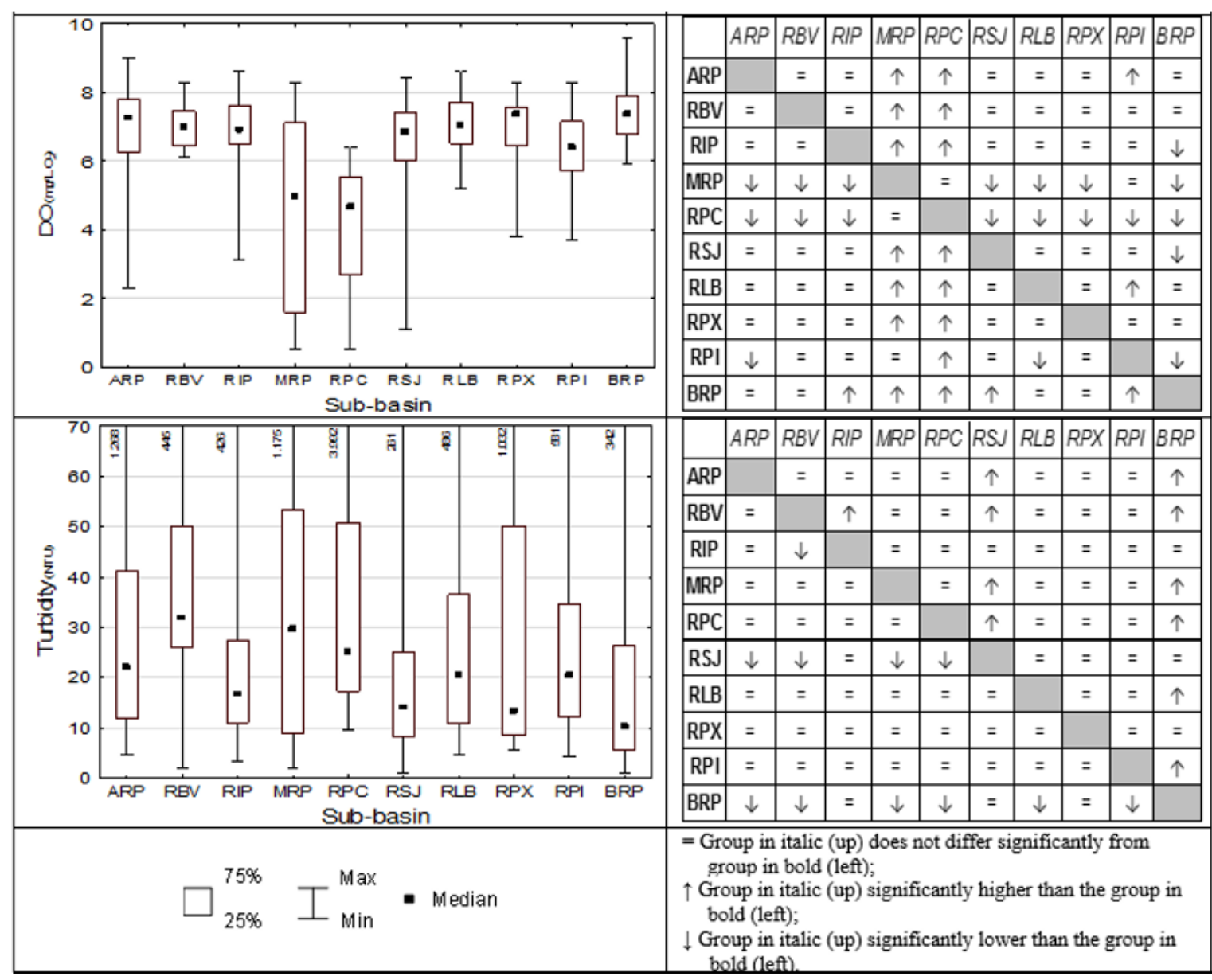

Figure 2 (continuation). Box-plots and tables from the multiple comparison test of parameters TC/ E. coli, $\mathrm{BOD}, \mathrm{P}_{\mathrm{T}}, \mathrm{DO}$ and Turbidity of the ten sub-basins.

For turbidity, the Boa Vista Brook sub-basin presented the highest median value, significantly higher than the values from the Itapecerica, São João and Lower Pará River subbasins, not differing itself from the others. Analyzing the boxplots and the multiple comparison tables, it was possible to identify the most- and least-impacted sub-basins.

Table 3 shows a summary of the most-impacted sub-basins and the responsible parameters according to the results of the multiple comparison tests. It can be observed that for $\mathrm{DO}, \mathrm{P}_{\mathrm{T}}$, BOD, TC/E. coli, Cl-T, Cl-a, CE, COD, N-NH4+ ${ }^{+}$pH, TS, MBAS and $\mathrm{Zn}_{\mathrm{T}}$, Da Paciência Brook sub-basin presents significantly higher concentrations when compared to other sub-basins (significantly lower for DO). These results are shown by the box-plots and evidenced by the multiple comparison test tables in Figure 2. This makes the Da Paciência Brook sub-basin the most-impacted in the Pará River basin.

This result refutes the hypothesis that the most-impacted municipalities contain the largest populations since, between the two municipalities that form the Da Paciência Brook sub-basin (Onça de Pitangui and Pará de Minas), only Pará de Minas is among the most populous ones. However, this sub-basin shows the highest population density, approximately 201 inhabitants $/ \mathrm{km}^{2}$. Along with this, there are many nonconformity generating foci in the contributing area, such as the release of natural sewage from the urban area of Pará de Minas, downstream the station; pig farming activities; granite, gold and rock-forming minerals mining; and effluents from leather tanning activities, which may generate high environmental impacts. This fact makes Da Paciência Brook sub-basin a priority for measures that control and monitor human occupation effluents (IGAM, 2016a). 
Table 3. Most impacted sub-basins in the Pará River Basin, considering concentrations significantly higher than the others.

\begin{tabular}{|c|c|c|c|}
\hline $\begin{array}{l}\text { Most impacted } \\
\text { sub-basins }\end{array}$ & Stations & Responsible parameters & Location \\
\hline RPC & PA010 & $\begin{array}{c}\mathrm{DO} ; \mathrm{P}_{\mathrm{T}} ; \mathrm{BOD} ; \mathrm{CT} / \text { E. coli; } \mathrm{Cl}-\mathrm{T} ; \mathrm{Cl}- \\
\text { a; } \mathrm{EC} ; \mathrm{COD} ; \mathrm{N}-\mathrm{NH}_{4}+; \mathrm{pH} ; \mathrm{TS} \\
\text { MBAS; } \mathrm{Zn}_{\mathrm{T}}\end{array}$ & Onça de Pitangui; Pará de Minas \\
\hline RBV & PA032 & Turbidity; TSS; temperature & $\begin{array}{l}\text { Carmo da Mata; Cláudio; } \\
\text { Divinópolis; Itapecerica; Oliveira; } \\
\text { São Sebastião do Oeste }\end{array}$ \\
\hline RPI & $\begin{array}{l}\text { PA017, } \\
\text { PA021 }\end{array}$ & $\mathrm{N}-\mathrm{NO}_{3-}$ & Martinho Campos; Bom Despacho \\
\hline
\end{tabular}

RPC - Da Paciência Brook; RBV - Boa Vista Brook; RPI - Picão River.

Then, there is the Boa Vista Brook sub-basin, which shows significantly higher concentrations for turbidity, TSS and temperature. Finally, the Picão River sub-basin, which presented $\mathrm{N}-\mathrm{NO}_{3}$ median concentrations significantly higher than other basins. Such results directly affect the life quality of the population, since they reduce the potential use of surface water and increase its costs for treatment and consumption in the cities of Pará de Minas (RPC), Carmo da Mata (RVB) and Martinho Campos (RPI).

Using the results of the multiple comparison tests, Table 4 was generated, with the summary of the least-impacted sub-basins and the parameters responsible for the better water quality condition. It can be verified that Do Peixe River sub-basin, located in the municipalities of Maravilhas; Onça de Pitangui; Papagaios; Pitangui and Pompéu, shows the most parameters with significantly lower concentrations when compared to other sub-basins, possibly being considered the least-impacted one. This result corroborates data contained in the Land Use Plan of the studied basin, where Do Peixe River sub-basin is considered to be the one detaining the lowest domestic effluent release flow (IGAM, 2016b). In the second place, comes Lower Pará River sub-basin, followed by Upper Pará River and Boa Vista Brook.

However, it is important to point out that the discrepancy in the station density in the subbasins might have also been a relevant factor for the results found. Meanwhile, there are subbasins with more than one monitoring station, there are others with only one (RBV, RPX and RPC), and far from the outfall. This may directly affect the concentration of parameters. Hence, the well-structured delineation and the adequacy of sampling networks, in strategic places, based on hydrological conditions, land use and occupancy, water quantity and quality and the location of the pollution sources in the hydrographic basin (Calazans, 2015).

\subsection{Compliance to legally established standard values}

Table 5 shows the percentage of compliance to the limits established by DN COPAM CERH 01/08, according to the pre-established class for each existing sampling point in the ten sub-basins. Among the results that showed the data that met the legal limits, are the ones obtained by Boa Vista Brook, for BOD and DO; Picão River, for BOD and Lower Pará River for DO. Regarding higher violation indexes, TC/E. coli stands out for showing the lowest compliance to the classification limits in all sub-basins, except in Da Paciência Brook subbasin, which compliance percentage for $\mathrm{P}_{\mathrm{T}}$ was even lower than the value found for TC/E. coli.

\section{IPABH}


Table 4. Least impacted sub-basins in the Pará River basin, considering concentrations significantly lower than the others.

\begin{tabular}{|c|c|c|c|}
\hline $\begin{array}{l}\text { Least } \\
\text { impacted sub- } \\
\text { basins }\end{array}$ & Stations & Responsible parameters & Location \\
\hline RPX & PA042 & $\begin{array}{l}\mathrm{Cl}-\mathrm{T} ; \mathrm{Cl}-a ; \mathrm{BOD} ; \mathrm{COD} ; \mathrm{P}_{\mathrm{T}} ; \mathrm{N}- \\
\mathrm{NO}_{3}^{-} ; \mathrm{N}^{-} \mathrm{NH}_{4}^{+} ; \mathrm{DO} ; \mathrm{TSS} ; \mathrm{TS} ; \mathrm{Zn}_{\mathrm{T}}\end{array}$ & $\begin{array}{l}\text { Maravilhas; Onça de Pitangui; } \\
\text { Papagaios; Pitangui; Pompéu }\end{array}$ \\
\hline BRP & $\begin{array}{l}\text { PA013, PA019, } \\
\text { PA044 }\end{array}$ & $\begin{array}{l}\mathrm{CT} / \text { E. coli } ; \mathrm{BOD} ; \mathrm{N}^{-\mathrm{NH}_{4}}{ }^{+} ; \mathrm{DO} ; \\
\text { turbidity; } \mathrm{Zn}_{\mathrm{T}}\end{array}$ & $\begin{array}{l}\text { Conceição do Pará; Leandro Ferreira; } \\
\text { Pitangui; Martinho Campos; Nova } \\
\text { Serrana; Pompéu }\end{array}$ \\
\hline ARP & $\begin{array}{l}\text { PA001, PA002, } \\
\text { PA003, PA024, } \\
\text { PA026 }\end{array}$ & EC; BOD; $\mathrm{pH}$; Temperature; $\mathrm{Zn}_{\mathrm{T}}$ & $\begin{array}{l}\text { Carmópolis de Minas; Cláudio; } \\
\text { Desterro de Entre Rios; Itaguara; } \\
\text { Oliveira; Passa Tempo; Piracema; } \\
\text { Resende Costa } \\
\text { Carmo da Mata; Cláudio; Divinópolis; }\end{array}$ \\
\hline RBV & PA032 & $\mathrm{BOD} ; \mathrm{N}-\mathrm{NH}_{4}^{+} ;$Temperature; $\mathrm{Zn}_{\mathrm{T}}$ & $\begin{array}{l}\text { Itapecerica; Oliveira; São Sebastião do } \\
\text { Oeste }\end{array}$ \\
\hline RLB & $\begin{array}{l}\text { PA015, PA022, } \\
\text { PA040 }\end{array}$ & $\mathrm{BOD} ; \mathrm{N}-\mathrm{NH}_{4}{ }^{+} ; \mathrm{Zn}_{\mathrm{T}}$ & $\begin{array}{l}\text { Araújos; Bom Despacho; Itapecerica; } \\
\text { Leandro Ferreira; Martinho Campos; } \\
\text { Nova Serrana; Santo Antônio do } \\
\text { Monte; São Sebastião do Oeste; Pedra } \\
\text { do Indaiá; Perdigão }\end{array}$ \\
\hline RIP & $\begin{array}{l}\text { PA004, PA007, } \\
\text { PA031 }\end{array}$ & $\mathrm{BOD} ; \mathrm{Zn}_{\mathrm{T}}$ & $\begin{array}{l}\text { Carmo da Mata; Divinópolis; } \\
\text { Itapecerica; São Francisco de Paula; } \\
\text { São Sebastião do Oeste }\end{array}$ \\
\hline RPI & PA017, PA021 & $\mathrm{BOD}$ & Bom Despacho; Martinho Campos \\
\hline MRP & $\begin{array}{l}\text { PA005, PA020, } \\
\text { PA028, PA034 }\end{array}$ & $\mathrm{Zn}_{\mathrm{T}}$ & $\begin{array}{l}\text { Carmo do Cajuru; Cláudio; Conceição } \\
\text { do Pará; Divinópolis; Nova Serrana; } \\
\text { Perdigão; São Gonçalo do Pará }\end{array}$ \\
\hline RSJ & $\begin{array}{l}\text { PA009, PA011, } \\
\text { PA036 }\end{array}$ & $\mathrm{Zn}_{\mathrm{T}}$ & $\begin{array}{l}\text { Igaratinga; Itaguara; Itatiaiuçu; Itaúna; } \\
\text { Carmo do Cajuru; Conceição do Pará; } \\
\text { Onça de Pitangui; Pará de Minas; } \\
\text { Pitangui; São Gonçalo do Pará }\end{array}$ \\
\hline
\end{tabular}

ARP - Upper Pará River; RBV - Boa Vista Brook; RIP - Itapecerica River; MRP - Middle Pará River; RPC - Da Paciência Brook; RSJ - São João River; RLB - Lambari River; RPX - Do Peixe River; RPI Picão River; BRP - Lower Pará River.

Table 5. Compliance percentage to the limits established by Joint Normative Deliberation COPAM/CERH-MG n. 01/08.

\begin{tabular}{lcccccccccc}
\hline Parameter & ARP & RBV & RIP & MRP & RPC & RSJ & RLB & RPX & RPI & BRP \\
\hline TC/ E. coli & $18 \%$ & $56 \%$ & $33 \%$ & $5 \%$ & $14 \%$ & $33 \%$ & $19 \%$ & $11 \%$ & $67 \%$ & $81 \%$ \\
BOD & $92 \%$ & $100 \%$ & $97 \%$ & $51 \%$ & $44 \%$ & $66 \%$ & $99 \%$ & $97 \%$ & $100 \%$ & $98 \%$ \\
$\mathrm{P}_{\mathrm{T}}$ & $82 \%$ & $94 \%$ & $63 \%$ & $51 \%$ & $11 \%$ & $46 \%$ & $84 \%$ & $92 \%$ & $93 \%$ & $99 \%$ \\
DO & $84 \%$ & $100 \%$ & $92 \%$ & $47 \%$ & $58 \%$ & $81 \%$ & $96 \%$ & $92 \%$ & $69 \%$ & $100 \%$ \\
Turb. & $76 \%$ & $94 \%$ & $91 \%$ & $82 \%$ & $83 \%$ & $96 \%$ & $87 \%$ & $72 \%$ & $82 \%$ & $94 \%$ \\
\hline
\end{tabular}

Considering the main economic activities and characteristics of the sub-basin, these violations are, above all, a strong indication of effluent release, soil erosion, intense mining activities, low flow indexes, diffuse pollution caused by agriculture and unprotected river springs.

\subsection{Effect of seasonality in surface water quality in the Pará River basin}

After applying statistical analyses, it was possible to identify the behavior of each parameter in the sub-basins in dry and rainy seasons. Figure 3 contains the box-plots that show 
the concentrations of parameters in dry and rainy seasons in sequence, aiming to ease the visualization of the results.

The results showed that from the 18 parameters analyzed, only DO, turbidity, TSS, TS and temperature showed significant differences at a $5 \%$ significance level.

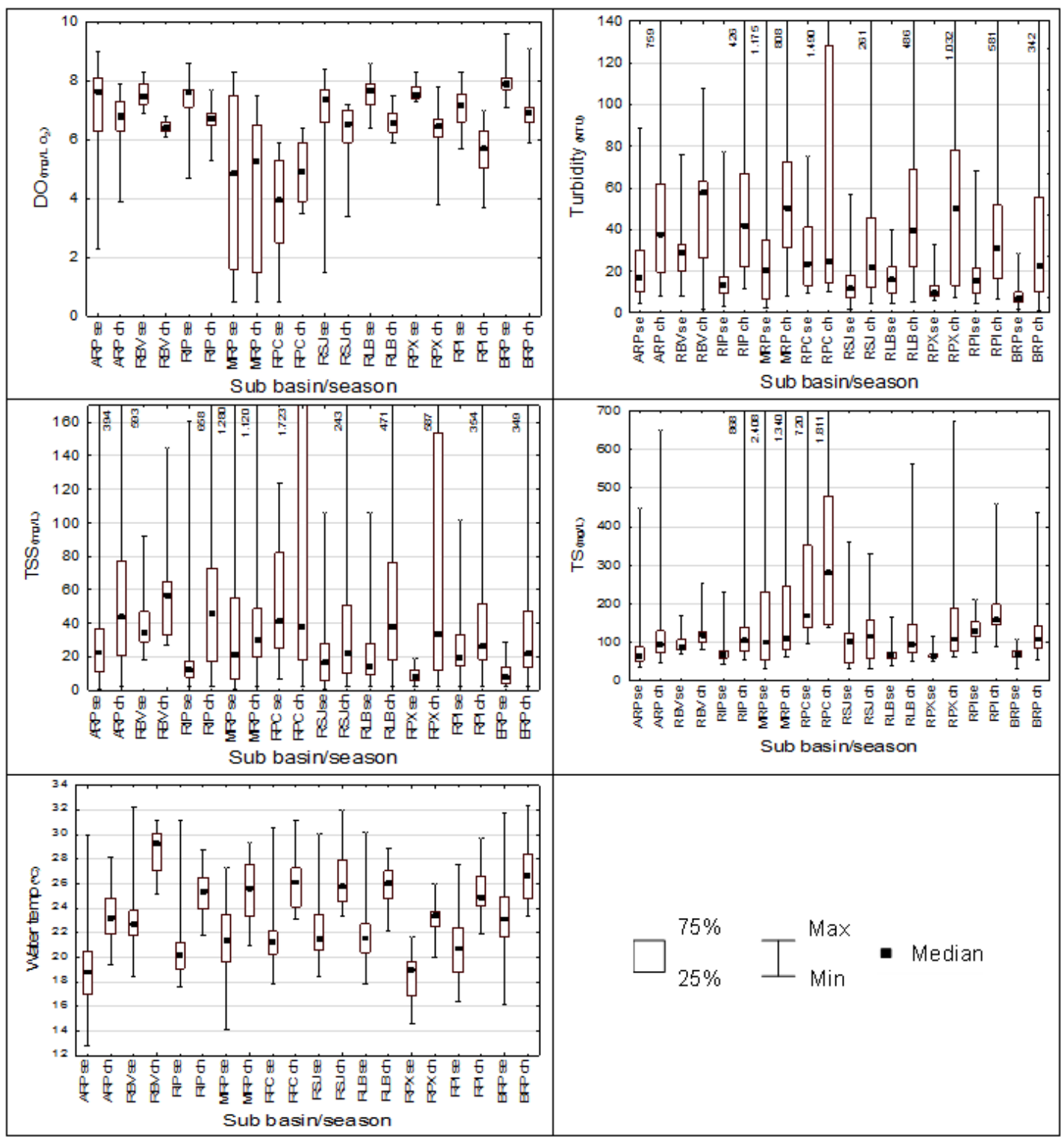

Figure 3. Box-plots of DO, turbidity, TSS, TS and water temperature concentrations, in the sub-basins (dry and rainy seasons).

"se" - dry season; "ch" - rainy season.

DO showed a similar behavior for most of the analyzed sub-basins. However, significant differences were found only in the medians of four sub-basins: Upper Pará River, Lambari River, Do Peixe River and Picão River. The median concentrations for this variable tended to be higher in the dry season when compared to the rainy. In the rainy season, the values are lower due to the increase in organic matter and nutrients in the river, transported by surface runoff, which leads to a higher DO consumption for the degradation of organic matter.

It is emphasized that, according to Table 3, Da Paciência Brook sub-basin was the most impacted concerning water quality. For turbidity, it is noticed that six sub-basins showed a significant difference between the medians obtained in the dry and rainy seasons.

\section{IPABH}

Rev. Ambient. Água vol. 14 n. 1, e2322 - Taubaté 2019 
For the ten sub-basins analyzed, turbidity values were more elevated in the rainy season, with the highest amplitude being found in Do Peixe River sub-basin. This behavior was already expected since rainfall leads to the carrying of suspended solids, dissolved chemical compounds and suspended particles such as silt, clay and organic matter into the water body.

TSS also showed a similar behavior, decreasing in the dry period. In the sub-basins of Itapecerica River, Do Peixe River and Lower Pará River, TSS concentration medians in the rainy season were significantly higher when compared to the dry season, and the one that showed the highest difference amplitude was the Itapecerica River sub-basin.

Total solids showed a similar behavior to TSS, having lower concentrations in the dry season in all sub-basins. Significant differences were found for the sub-basins of Upper Pará River, Itapecerica River, Lambari River and Lower Pará River. Lastly, concerning water temperature, the values were lower in the dry period for all sub-basins, showing a significant difference in eight out of the ten evaluated sub-basins.

These results reflect the influence of seasonality in surface waters quality in the Pará River Basin, exposing that, despite the higher flow and resulting dilution, there is a worsening in the concentration of parameters in the rainy season for almost all sub-basins, owing to the soil carried into the water body.

\section{FINAL CONSIDERATIONS}

The water quality comparison between the ten sub-basins of the Pará River identified significant differences for the concentrations of all evaluated water quality parameters.

Regarding compliance to the law, all sub-basins presented themselves out of the classification for at least one of the evaluated parameters, and in these cases, the new classification suggests an inferior water quality class compared to the previously established one. TC/E. coli was the parameter with the lowest compliance to the classification limits in all sub-basins, reaching a violation of $95 \%$ to the current standards for the classification classes of the water bodies of Middle Pará River, and $89 \%$ in Do Peixe River sub-basin. Considering $\mathrm{P}_{\mathrm{T}}$ in Da Paciência Brook, its compliance percentage reached only $11 \%$.

The seasonality evaluation pointed out significant differences between 5 of the 18 evaluated parameters: DO, turbidity, TSS, TS and water temperature. All parameters analyzed demonstrated a decrease in water quality in the rainy period for most sub-basins.

The most-impacted sub-basins regarding surface water quality, considering significantly higher concentrations than others were: Da Paciência Brook (13 of 18 parameters) and Da Boa Vista Brook (3 of 18 parameters). On the other hand, the least-degraded sub-basins, considering concentrations that were significantly lower others were: Do Peixe River, Lower Pará River and Upper Pará River.

The disparity in the number of monitoring stations between the regions is also noticeable.

Da Boa Vista Brook, Da Paciência Brook and Do Peixe River sub-basins only have one station each and may not be representing the real situation of the entire sub-basin properly. However, the other sub-basins have most of the monitoring stations.

This work begins the surface water quality monitoring studies in the Pará River Basin and exposes the environmental damage level that the basin is exposed to. Thus, it may be used as a reference in order to establish more strategic goals and management instruments aiming at the sustainable development of the region, leading to an improvement in the living conditions of local people. 


\section{REFERENCES}

BARAKAT, A.; MOHAMED, M. A.; RAISA, J.; AGHEZZAFB, B.; M. Assessment of spatial and seasonal water quality variation of Oum Er Rbia River (Morocco) using multivariate statistical techniques. International Soil and Water Conservation Research, v. 4, p. 284-292, 2016. https://doi.org/10.1016/j.iswcr.2016.11.002

CALAZANS, G. M. Avaliação e proposta de adequação da rede de monitoramento da qualidade das águas superficiais das sub-bacias do rio das Velhas e do Rio Paraopeba utilizando técnicas estatísticas multivariadas. 2015. 196f. Dissertation (Masters in Sanitation, Environment and Water Resources) - Engineering School, Minas Gerais Federal University, Belo Horizonte. 2017. Available at: http://www.smarh.eng.ufmg.br/defesas/1138M.PDF

CHRISTOFARO, C.; LEÃO, M. M. D.; OLIVEIRA, S. C.; VIANA, D. T.; AMORIM, C. C.; CARVALHO, M. D. Spatio-temporal variations of water quality in Nova Ponte Reservoir, Araguari River Basin, Brazil. Water Science and Technology: Water Supply, v. 22, 2017. http://dx.doi.org/10.2166/ws.2017.055

COMISSÃO DE POLÍTICA AMBIENTAL (MG). Deliberação Normativa n. 28, de 09 de setembro de 1998. Dispõe sobre o enquadramento das águas da Bacia do rio Pará. Diário do Executivo, Belo Horizonte, 17 set. 1998.

COMISSÃO DE POLÍTICA AMBIENTAL (MG); CONSELHO ESTADUAL DE RECURSOS HÍDRICOS (MG). Deliberação Normativa Conjunta COPAM/CERH-MG n. 01, de 05 de maio de 2008. Dispõe sobre a classificação dos corpos de água e diretrizes ambientais para o seu enquadramento e estabelece as condições e padrões de lançamento de efluentes, e dá outras providências. Diário do Executivo, Belo Horizonte, 20 maio 2008 .

COSTA, E. P.; PINTO, C. C.; SOARES, A. L. C.; MELO, L. D. V.; OlIVEIRA, S. C. Evaluation of violations in water quality standards in the monitoring network of São Francisco River basin, the third largest in Brazil. Environmental Monitoring and Assessment, v. 189, p. 1-16, 2017. https://doi.org/10.1007/s10661-017-6266-y

DELKASH, M.; AL-FARAJ, F. A. M.; SCHOLZ, M. Impacts of Anthropogenic Land Use Changes on Nutrient Concentrations in Surface Waterbodies: A Review. CLEAN - Soil, Air, Water, v. 46, n. 5, p. 1-10, 2018. http://doi.wiley.com/10.1002/clen.201800051

FERRIER, R. C.; EDWARDS, A. C.; HIRST, D.; LITTLEWOOD, I. G.; WATTS, C. D.; MORRIS, R. Water Quality of Scottish Rivers: Spatial and Temporal Trends. Science of the Total Environment, v. 265, p. 327-342, 2001. https://doi.org/10.1016/S00489697(00)00674-4

GEBLER, D.; WIEGLEB, G.; SZOSZKIEWICZ. Integrating river hydromorphology and water quality into ecological status modelling by artificial neural networks. Water research, v. 139. p. 395-405, 2018. https://doi.org/10.1016/j.watres.2018.04.016

GIRI, S; QIU, Z. Understanding the relationship of land uses and water quality in Twenty-First Century: A review. Journal of Environmental Management, v. 44, 2016. https://doi.org/10.1016/j.jenvman.2016.02.029

INSTITUTO MINEIRO DE GESTÃO DAS ÁGUAS - IGAM. Monitoramento da qualidade das águas superficiais da bacia do rio São Francisco e seus afluentes em 2009. Belo Horizonte, 2010a. 287p. 
INSTITUTO MINEIRO DE GESTÃO DAS ÁGUAS - IGAM. Monitoramento da qualidade das águas superficiais na sub-bacia do rio Pará em 2009. Belo Horizonte, 2010b. 170p.

INSTITUTO MINEIRO DE GESTÃO DAS ÁGUAS - IGAM. Plano diretor da bacia hidrográfica do rio Pará alto rio São Francisco Minas Gerais: Etapa 2 - caracterização do sistema sócio-econômico. Belo Horizonte, 2016a. 452p.

INSTITUTO MINEIRO DE GESTÃO DAS ÁGUAS - IGAM. Plano diretor da bacia hidrográfica do rio Pará alto rio São Francisco Minas Gerais: Etapa 3 - avaliação e análise ambiental. Belo Horizonte, 2016b. 437p.

INSTITUTO MINEIRO DE GESTÃO DAS ÁGUAS - IGAM. Plano diretor da bacia hidrográfica do rio Pará alto rio São Francisco Minas Gerais: Etapa 4 - caracterização do sistema sócio-econômico. Belo Horizonte, 2016c. 437p.

INSTITUTO MINEIRO DE GESTÃO DAS ÁGUAS - IGAM. Sala de situação de eventos hidrometeorológicos críticos de Minas Gerais. Belo Horizonte, 2016d.

INSTITUTO MINEIRO DE GESTÃO DAS ÁGUAS - IGAM. Monitoramento da qualidade das águas. Belo Horizonte, 2018.

KAZI, T. G.; ARAIN M.B.; JAMALI, M. K.; JALBANI, N.; AFRIDI, H. I.; SARFRAZ, R. A.; BAIG J. A; SHAH, Q. Assessment of water quality of polluted lake using multivariate statistical techniques: A case study Pakistan. Ecotoxicology and environmental safety, n. 72, p. 301-309, 2009. https://doi.org/10.1016/j.ecoenv.2008.02.024

OLIVEIRA, S. C.; AMARAL, R. C.; ALMEIDA, K. C. B.; PINTO, C. C. Qualidade das águas superficiais do Médio São Francisco após a implantação dos perímetros irrigados de Gorutuba/Lagoa Grande e Jaíba. Revista de Engenharia Sanitária e Ambiental, v. 22, p. 711-721, 2017. http://dx.doi.org/10.1590/s1413-41522017136784

PFAFSTETTER, O. Classificação de Bacias Hidrográficas: Metodologia de Codificação. Rio de Janeiro: DNOS, 1989.

SIMEONOV, V.; STRATIS, J. A.; SAMARA, C.; ZACHARIADIS, G.; VOUTSA, D.; ANTHEMIDIS, A. et al. Assessment of the surface water quality in Northern Greece. Water Research, v. 37, p. 4119-4124, 2003. https://doi.org/10.1016/S00431354(03)00398-1

PINTO, C. C.; ANDRADE, S. B.; PINTO, É. A.; OLIVEIRA, S. C. Trend analysis of the load and concentration of physical, chemical and biological parameters in the Verde River Basin. Revista Brasileira de Recursos Hídricos, v. 22, 2017. http://dx.doi.org/10.1590/2318-0331.0117160030

TRINDADE, A. L. C.; ALMEIDA, K. C. B.; BARBOSA, P. E.; OLIVEIRA, S.C. Tendências temporais e espaciais da qualidade das águas superficiais da sub-bacia do rio das Velhas, estado de Minas Gerais. Revista de Engenharia Sanitária e Ambiental, n. 1, p. 1-12, 2016. http://dx.doi.org/10.1590/s1413-4152201613145

ZEINALZADEHA, K.; REZAEI, E. Determining spatial and temporal changes of surface water quality using principal component analysis 2017. Journal of Hydrology: Regional Studies, v. 13, p. 1-10, 2017. https://doi.org/10.1016/j.ejrh.2017.07.00v 


Ambiente \& Água - An Interdisciplinary Journal of Applied Science
ISSN 1980-993X - doi:10.4136/1980-993X
www.ambi-agua.net
E-mail: ambi.agua@gmail.com

\title{
High concentrations of toxic metals in water consumed by the Maxakali indigenous community in Brazil
}

\author{
ARTICLES doi:10.4136/ambi-agua.2215
}

Received: 23 Nov. 2017; Accepted: 12 Nov. 2018

\section{Eliseu Miranda de Assis ${ }^{1 *(D)}$; Maicon Junior dos Santos Souza ${ }^{2}$; Márcia Cristina da Silva Faria ${ }^{2}$; Jairo Lisboa Rodrigues ${ }^{2}{ }^{D}$; Anderson Garcez ${ }^{1}$; Cleide Aparecida Bomfeti ${ }^{-1 D}$; Nêmora Tregnago Barcellos ${ }^{1}$ iD}

\author{
${ }^{1}$ Universidade do Vale do Rio dos Sinos (Unisinos), São Leopoldo, RS, Brasil \\ Programa de Pós-graduação em Saúde Coletiva. E-mail: eliseumiranda@ifba.edu.br, \\ adsgarcez@gmail.com,nemoratb@gmail.com \\ ${ }^{2}$ Universidade Federal dos Vales do Jequitinhonha e Mucuri (UFVJM), Teófilo Otoni, MG, Brasil \\ Instituto de Ciência, Engenharia e Tecnologia (ICET). E-mail: maiconjunior.ufvjm@ @otmail.com, \\ marcia.faria@ufvjm.edu.br, jairo.rodrigues@ufvjm.edu.br, cleide.bomfeti@ufvjm.edu.br \\ *Corresponding author
}

\begin{abstract}
The Maxakali is the second largest indigenous population in the state of Minas Gerais, Brazil; and parasitic diseases are its main cause of death. Problems related to the quality of water consumed by this population, added to the absence of public sanitation services, aggravate the risk of illnesses due to several water-borne pathologies. Thus, the main purpose of this paper was to evaluate the water quality consumed in natura by the Maxakali community, quantifying toxic metals in relation to the maximum values allowed by Brazilian law. A descriptive cross-sectional study was carried out with samples of water collected in surfaceand groundwater in the Maxakali villages, including three seasonal periods. Villages with the greatest number of altered measures of metals in water were Aldeias Pradinho (100\%) and Água Boa (92\%). The smallest number of changes were found in Aldeias Verde and Rafael (27\%). The metals that appeared in the largest number of collections with values higher than recommended were Iron (50\%), followed by Arsenic (46\%), Aluminum (36\%), Cadmium $(22 \%)$ and Mercury (20\%), respectively. The study identified high concentrations of toxic metals in the water consumed by the Maxakali indigenous community in Brazil.
\end{abstract}

Keywords: Maxakali Indians, surface and underground water, toxic metals, water quality.

\section{Concentrações elevadas de metais tóxicos na água consumida pela comunidade indígena Maxakali no Brasil}

\section{RESUMO}

O povo Maxakali é a segunda maior população indígena aldeada no Estado de Minas Gerais, Brasil, tendo nas doenças infecciosas e parasitárias, sua principal causa de morte. Problemas com a qualidade da água consumida por essa população, somados à ausência dos serviços públicos de saneamento, agravam o risco de adoecimento por diversas patologias de veiculação hídrica. Assim, um estudo descritivo de desenho transversal, com amostras de água coletadas em locais de captação para consumo, foi realizado nas aldeias em três períodos 
sazonais, com objetivo de avaliar a água consumida, através da quantificação de metais tóxicos em relação aos valores máximos permitidos na legislação brasileira. As aldeias com maior número de medidas alteradas de metais na água foram, a Aldeia Pradinho (100\%), seguida de Água Boa (92\%). Os menores números de alterações foram encontrados nas Aldeias Verde e Rafael (27\%). Os metais que apareceram em maior número de amostras com valores acima do recomendado foram o Ferro (50\%), seguido do Arsênio (46\%), Alumínio (36\%), Cádmio (22\%) e o Mercúrio (20\%). Dessa forma, este estudo identificou altas concentrações de metais tóxicos na água consumida pelas comunidades indígenas de Maxakali no Brasil.

Palavras-chave: água superficial e subterrânea, índios Maxakali, metais tóxicos, qualidade da água.

\section{INTRODUCTION}

The Maxakali are the second largest indigenous population in the State of Minas Gerais, located in the Southeast region of Brazil, including approximately 2020 individuals (Brasil, 2015). Although they live in villages, the Maxakali indigenous community travels through several cities in the Northeast of the state, between the Mucuri, Jequitinhonha and Rio Doce valleys. In this region, the advance of agriculture and livestock, as well as the inadequate occupation of the soil close to springs and the large hydrographic basins have favored the emergence of potential toxins in these environments, which contaminate the natural reservoirs and greatly impact human health and local flora and fauna (Derisio, 1992). In addition, the hydrographic basins where Maxakali villages are located have received large loads of waste from anthropic activities due to the disorderly urban development, such as the in natura discharge of industrial and domestic sewage from the cities that make up this micro region (Blanc et al., 2013).

The indigenous people usually consume fresh water, taking into account visual, olfactory and palatability characteristics. However, the senses that evaluate the quality of water used for human consumption, which identify organoleptic characteristics that express taste, color and odor, may not reveal the actual sanitary water condition. This fact, coupled with the precariousness of the public sanitation services, which determine the lack of systematic evaluations and the guarantee of minimum standards of potability, aggravates the risk of waterborne diseases in this vulnerable population group due to nutritional and parasitic conditions (Borges et al., 2009; Assis et al., 2013). In this sense, the risk of consumption of fresh water in Maxakali indigenous communities is evidenced by the high presence of intestinal parasites in this population (Assis et al., 2013). In addition, a recent study identified high concentrations of toxic metals in rivers and tributaries near the regions of the Maxakali villages (Blanc et al., 2013).

Although there are Brazilian standards to evaluate the quality of consumed water, including an Ordinance of The Brazilian Ministry of Health, and resolutions from The National Council of the Environment - CONAMA, there is a lack of public policies of sanitation and water quality monitoring, especially in rural communities where social, educational and health programs are extremely precarious. This context shows the need of wide-ranging studies of the quality of the water for consumption, especially for concentrations of highly toxic heavy metals, capable of irritating the skin and causing gastrointestinal disorders, neurological disorders and carcinogenesis (Melville and Burchett, 2002). In addition, the concentration of heavy metals has not yet been used to evaluate the quality of the raw water utilized for public drinking water supplies in Brazil (Bollmann and Marques, 2000). This study therefore evaluated the concentrations of toxic metals in surface water and underground water consumed in natura by the Maxakali indigenous community in Brazil, including three seasonal periods. 


\section{MATERIALS AND METHODS}

A cross-sectional descriptive study was conducted, including water samples collected in three seasonal periods from all official and unofficial sources of water consumed by the indigenous Maxakali community. The study was carried out on the Maxakali lands, located in the northeast region of the State of Minas Gerais, Southeast region of Brazil (Figure 1).

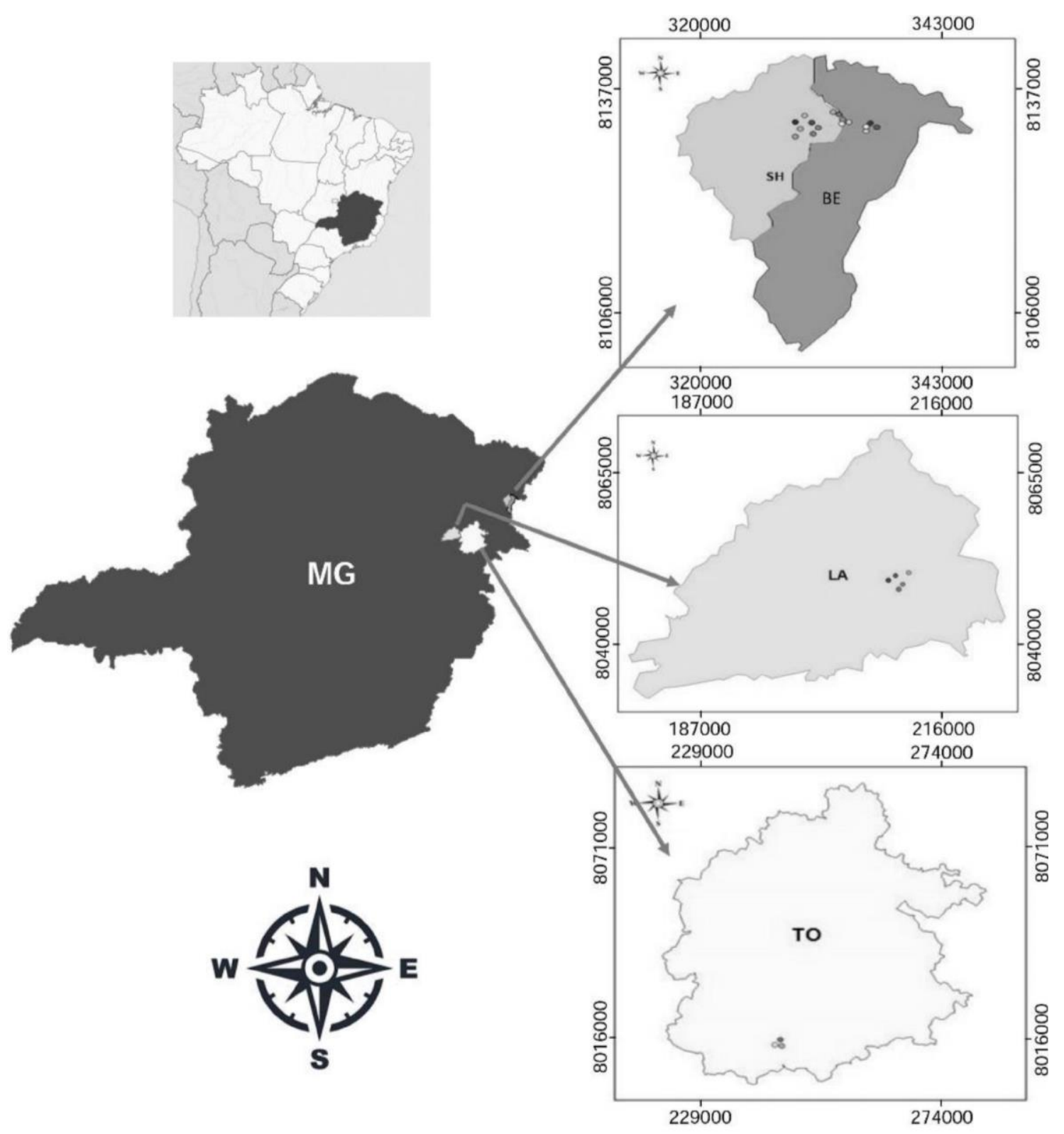

Figure 1. Location of the study area with collection points in the four Maxakali indigenous villages, Minas Gerais, Brazil. MG: state of Minas Gerais (Brazil), SH: city of Santa Helena de Minas, BE: city of Bertópolis, LA: city of Ladainha, TO: city of Teófilo Otoni (district of Topázio).

The territory corresponds to the villages of Água Boa (city of Santa Helena de Minas), Pradinho/Vila Nova (city of Bertópolis/MG), Aldeia Verde (city of Ladainha) and Aldeia Cachoeirinha/Rafael in Topázio district (city of Teófilo Otoni/MG). The Aldeia Pradinho (Vila Nova) and Aldeia Água Boa are located in an area of approximately 5,305 hectares. Hydrographically, these two indigenous lands that are largest in territorial extension and in population, are located in the headwaters of Itanhém River tributaries, the Itanhém River Basin, 
which flows into the Atlantic Ocean at the city of Alcobaça/BA. They belong politically and administratively to the region of Mucuri Valley, in the Northeast region of Minas Gerais. Aldeia Verde is located in the city of Ladainha/MG, occupying 552 hectares, where hills and low soil fertility predominate (Carvalho, 2000). Aldeia Cachoeirinha (Aldeia de Rafael), in Topázio, district of Teófilo Otoni/MG, has been in existence for less than nine years with poor road infrastructure and lack of sanitation. Both Aldeia Verde and Aldeia Rafael are located in the Mucuri River Basin.

Twenty-four points were mapped (nine in Aldeia Pradinho/Vila Nova, seven in Aldeia Água Boa, five in Aldeia Verde and three in Aldeia Rafael/Cachoeirinha): four artesian wells, five reservoirs, six ends of the water network, a river, five streams, two lagoons and a water spring. (Supplementary Table 1 S1) shows the description of the points mapped, including the geodetic coordinates information. The five freshwater streams are mostly born within the boundaries of the villages. In drought periods, these streams can be considered as lentic environment with almost stagnant water, classified as Class II (intended for domestic supply after conventional treatment). However, due to the in natura consumption at times of recreation and fishing activities, they were classified as Class I (water used for domestic supply after simplified treatment) for evaluation purposes. The freshwater river (lotic environment) is born outside the boundaries of the village and was classified as Class I, since it is consumed in natura. This river receives a moderate load of domestic sewage coming from farms and the town of Oropinha in the district of Santa Helena de Minas/MG, before passing through the village.

Sample collection and preservation, including all quality assurance and quality control procedures, strictly followed the protocols recommended by the Environmental Sanitation Technology Company of São Paulo (Companhia de Tecnologia de Saneamento Ambiental) (CETESB, 2011). Samples were collected and identified in $50 \mathrm{ml}$ of metal-free polypropylene bottles (Falcon BD $®)$, stored in temperature-controlled thermal boxes and immediately sent for processing. Prior to sample collection, our group ruled out the presence of any kind of metal in the polypropylene bottles used in this study, including mercury. All reagents used in the cleaning procedure of the sampling material were analytical-reagent grade, including nitric acid 65\% (HNO3) obtained from Sigma Aldrich ${ }^{\circledR}$. High-purity deionized water (resistivity 18.2 M $\Omega$ $\mathrm{cm}-1$ ) obtained using a Milli-Q water purification system (Millipore, Bedford, MA, USA) was also used throughout. All solutions were stored in high-density polyethylene bottles. Plastic materials were cleaned by soaking in $10 \%$ (v/v) HNO3 for 48 hours, rinsed five times with Milli-Q water and dried in a Class 100 laminar flow hood before use. All operations were performed on a clean bench. Multi-element stock solutions containing $1000 \mathrm{mg} \mathrm{L}-1$ of each element were obtained from Perkin-Elmer (PerkinElmer, Norwalk, CT, USA).

The sample collection was made at three times, with a seasonal criterion including dry, intermediate and rainy periods. The first collection occurred in January 2015, considered the rainy period for the region by the weather forecast. However, in that period there was no rain. The second collection was carried out in April 2015, considered the intermediate period by the weather forecast when the temperatures were mild, still without voluminous rains, but with discreet precipitations, insufficient to recharge the rivers, streams and wells. The third collection was in July 2015, under heavy rains, although the weather report had announced a dry period. The climatic variations did not impact the study, since it was intended to evaluate moments of greater dilution favored by rain and lower dilution favored by the drought.

Metals and semi-metals concentrations were evaluated, including: aluminum, arsenic, barium, cadmium, lead, copper, chromium, iron and mercury, and their respective cut points were considered altered when they reached the Maximum Permitted Values (MPV) for each element above acceptable for surface and groundwater, taking into consideration the ordinance of the Ministry of Health 2914/2011 and The National Council of the Environment - CONAMA 
resolutions 357/2005 and 396/2008. For the definition of normal or altered quantities, all reference values have been converted into units of micrograms per liter $(\mu \mathrm{g} / \mathrm{l})$ since some MPVs refer to $\mathrm{mg} / \mathrm{L}$ unit. For the determination of metals, the analytical method proposed by Lawrence et al. (2006) was used. The analyzes were processed in a Clean Room Class 1000 based on the water analysis method 200.8 PerkinElmer (Pruszkowski and Bosnak, 2012), using an inductively coupled plasma mass spectrometer (ICP-MS) NexIon 300D (USA). Quality control for the determination of metals in the water samples was carried out via analysis of water standard reference materials (Aluminum, Arsenic, Barium, Cadmium, Chromium, Copper, Iron, Lead) from the National Institute of Standards and Technology (NIST 1640a, Trace Elements in Natural Water; NIST 1643e, Trace Elements in Water; and NIST 1641e, Mercury in water). The reference samples were analyzed before and after ten runs of ordinary water samples. There were no statistical differences between the concentration values obtained for the reference materials and the "target-values" for $95 \%$ confidence intervals using the Ttest. These results confirm the accuracy of the method. In study of the precision (intra-day and inter-day precision) the relative standard deviation (RSD) was less than $1.8 \%$ (intra-day precision) and less than $2.0 \%$ (inter-day precision) for all elements analyzed.

Statistical analyses were conducted with the main objective of comparing the concentration levels of toxic metals. The results were typed (double entry and correction of inconsistencies) in the SPSS Software, Version 22 (SPSS Inc., Chicago, IL, EUA). Variables were created for each cutoff point in relation to the MPV. The Student's t-test for comparison of metal concentration averages was used, including the respective 95\% confidence intervals (CI 95\%), and comparative analysis of the results was obtained with the reference values provided by literature. Statistical analyses were performed in relation to the collection point, village, seasonality and the origin of the water (superficial or underground).

This study was submitted and approved (protocol number 129/2015) by the Ethics and Research Committee of the University of Vale do Rio do Sinos - UNISINOS. Indigenous leaderships and the Special Indigenous District of Minas Gerais / Espirito Santo have also approved this research.

\section{RESULTS AND DISCUSSION}

Regarding the origin of the water, 10 points (42\%) were groundwater and $14(58 \%)$ of surface water, most of them artesian wells or dams made in springs. The artesian wells sampled had depths between 30 and 120 meters, with flows from 2500 to 8300 1/hour. The connections and pipelines were galvanized, and water belonging to Class I by resolution CONAMA 375/2005. The five reservoirs with 13 storage units were mostly PVC boxes with a capacity of 15 thousand liters and the rest were the iron base with capacity of more than 20 thousand liters.

In the general context, Aldeia Verde and Rafael were the ones that presented the smallest changes in the dosage of the evaluated metals. All the evaluated metals had their values changed at some point in the study in Aldeia Pradinho. Similar results were found in Aldeia Água Boa, where eight of the nine evaluated elements disagreed with the standards established for human consumption (Table 1). When individualized, the aluminum presented values above the maximum allowed limit in 14 of the 24 evaluated points. In the dry period, its minimum concentration was 25.16 micrograms per liter $(\mu \mathrm{g} / \mathrm{L})$ and its maximum concentration was 49,206 $(\mu \mathrm{g} / \mathrm{L})$, at point AP4 at the Aldeia Pradinho, representing an increase of more than 200 times in relation to MPV (100 $\mu \mathrm{g} / \mathrm{L}$ for surface water and $200 \mu \mathrm{g} / \mathrm{L}$ for groundwater). (Supplementary Table 2 S2) shows the analytical results in trace metals concentrations $(\mu \mathrm{g} / \mathrm{L})$ in the three seasonal periods at twenty-four collection points in Maxakali Villages. 
Table 1. Number and percentage of analyzes of metals and semimetals with a dosage above that allowed for consumption in the Maxakali villages, Minas Gerais, Brazil.

\begin{tabular}{|c|c|c|c|c|c|c|c|c|}
\hline \multirow{3}{*}{ Metals } & \multicolumn{8}{|c|}{ Villages } \\
\hline & \multicolumn{2}{|c|}{ Pradinho } & \multicolumn{2}{|c|}{ Água Boa } & \multicolumn{2}{|c|}{ Verde } & \multicolumn{2}{|c|}{ Rafael } \\
\hline & $(\mathrm{a} / \mathrm{C})(\%)$ & Min/Max & $(a / C)(\%)$ & Min/Max & $(\mathrm{a} / \mathrm{C})(\%)$ & Min/Max & $(\mathrm{a} / \mathrm{C})(\%)$ & Min/Max \\
\hline Al & $06 / 27(22)$ & $124.3 / 49206$ & 04/21 (19) & 101.2/7238.8 & $10 / 15(67)$ & $100.9 / 828.3$ & 06/09 (67) & $106.9 / 131.59$ \\
\hline As & $10 / 27(37)$ & $15.3 / 182.1$ & $07 / 21(33)$ & $152.2 / 166.8$ & $10 / 15(67)$ & $143.6 / 169.4$ & 06/09 (67) & $144.2 / 154.9$ \\
\hline $\mathbf{B a}$ & $02 / 27(7.4)$ & $4.23 / 956.5$ & 04/21 (19) & $2.9 / 236.6$ & - & $<\mathrm{LQO}$ & - & $<\mathrm{LQO}$ \\
\hline Cd & $09 / 27(33)$ & $5.07 / 5.15$ & $07 / 21(33)$ & $5.07 / 5.08$ & - & $<$ LQO & - & $<\mathrm{LQO}$ \\
\hline $\mathrm{Cr}$ & $01 / 27(3.7)$ & 56.9 & - & $<\mathrm{LQO}$ & - & $<\mathrm{LQO}$ & - & $<\mathrm{LQO}$ \\
\hline $\mathbf{C u}$ & $02 / 27(7.4)$ & $11.04 / 37.8$ & $02 / 21(9.5)$ & $11.4 / 13.7$ & - & $<$ LQO & - & $<\mathrm{LQO}$ \\
\hline $\mathbf{F e}$ & $16 / 27(59)$ & $623.1 / 88664.7$ & $12 / 21(57)$ & $323.9 / 25078.1$ & $04 / 15(27)$ & $303.4 / 13173.5$ & $04 / 09$ (44) & $452.9 / 13252.5$ \\
\hline $\mathbf{H g}$ & 08/18 (44) & $2.8 / 17.9$ & $07 / 14(50)$ & $13.6 / 14.26$ & - & $<\mathrm{LQO}$ & - & $<\mathrm{LQO}$ \\
\hline $\mathbf{P b}$ & $03 / 27(11)$ & $11.4 / 52.1$ & $01 / 21(4.7)$ & 12.5 & - & $<$ LQO & - & $<\mathrm{LQO}$ \\
\hline
\end{tabular}

Al-Aluminum, As-Arsenic, Ba-Barium, Cd-Cadmium, Cu-Copper, Cr-Chromium, Fe-Iron, Hg-Mercury, Pb-Lead, a- number of altered analyzes, Cnumber of collections which were made, $(-)<$ LQO below the limit of quantification, Min - minimum value observed in the samples, Max - maximum value observed in the samples. 
In Aldeia Pradinho (AP), some changes were identified at points AP4, AP5 and AP6. In Aldeia Água Boa (AB), the changes were visible at points $A B 1, A B 4, A B 5$ and AB7, with emphasis on the value that was found at point AB4 in the dry period $(7238,83 \mu \mathrm{g} / \mathrm{L})$. In Aldeia Verde (AV), there were changes in four of the five evaluated points, with little variation in relation to seasonality. Points AV1, AV2, AV4 and AV5 presented concentrations above the recommended limit, although in most of them, those values were very close to the acceptable limit. The same happened in Aldeia Rafael (AR) in the intermediate and rainy periods, except in the dry period (Table 2).

Table 2. Number of collections and metals with above permitted dosage, according to seasonality, for consumption in the Maxakali Villages, Minas Gerais, Brazil.

\begin{tabular}{|c|c|c|c|c|c|c|c|c|c|c|c|}
\hline \multirow[b]{2}{*}{ Villages } & \multicolumn{11}{|c|}{ Metals } \\
\hline & Points & $\mathbf{A l} *$ & As* & $\mathbf{B a}^{*}$ & $\mathbf{C d}^{*}$ & $\mathrm{Cu}^{*}$ & $\mathrm{Cr}^{*}$ & $\mathbf{F e}^{*}$ & $\mathbf{H g}^{* * *}$ & $\mathbf{P b} *$ & $\begin{array}{c}\text { Total metals with } \\
\text { change at each } \\
\text { point }(\mathrm{N}-9)\end{array}$ \\
\hline \multirow{9}{*}{ Pradinho } & AP1 & - & $2(\mathrm{I})$ & - & $1(\mathrm{C})$ & - & - & $2(\mathrm{~S} / \mathrm{C})$ & $1(\mathrm{C})$ & $1(\mathrm{C})$ & 5 \\
\hline & AP2 & - & $1(\mathrm{I})$ & - & $1(\mathrm{C})$ & - & - & $1(\mathrm{~S})$ & - & - & 3 \\
\hline & AP3 & - & $1(\mathrm{I})$ & - & $1(\mathrm{C})$ & - & - & $1(\mathrm{~S})$ & $1(\mathrm{C})$ & - & 3 \\
\hline & AP4 & $1(\mathrm{~S})$ & 1(I) & $1(\mathrm{~S})$ & $1(\mathrm{C})$ & $1(\mathrm{~S})$ & $1(\mathrm{~S})$ & $2(\mathrm{~S} / \mathrm{C})$ & $1(\mathrm{C})$ & $1(\mathrm{~S})$ & 9 \\
\hline & AP5 & $3(\mathrm{~S} / \mathrm{I} / \mathrm{C})$ & $1(\mathrm{I})$ & $1(\mathrm{~S})$ & $1(\mathrm{C})$ & - & - & $2(\mathrm{~S} / \mathrm{C})$ & $1(\mathrm{C})$ & $1(\mathrm{~S})$ & 7 \\
\hline & AP6 & $2(\mathrm{I} / \mathrm{C})$ & $1(\mathrm{I})$ & - & $1(\mathrm{C})$ & $1(\mathrm{C})$ & - & $1(\mathrm{~S})$ & $1(\mathrm{C})$ & - & 6 \\
\hline & AP7 & - & $1(\mathrm{I})$ & - & $1(\mathrm{C})$ & - & - & $3(\mathrm{~S} / \mathrm{I} / \mathrm{C})$ & $1(\mathrm{C})$ & - & 4 \\
\hline & AP8 & - & $1(\mathrm{I})$ & - & $1(\mathrm{C})$ & - & - & $2(\mathrm{~S} / \mathrm{C})$ & $1(\mathrm{C})$ & - & 4 \\
\hline & AP9 & - & 1(I) & - & $1(\mathrm{C})$ & - & - & $2(\mathrm{~S} / \mathrm{C})$ & $1(\mathrm{C})$ & - & 4 \\
\hline \multirow{7}{*}{ Água Boa } & $\mathrm{AB} 1$ & $1(\mathrm{C})$ & 1(I) & - & $1(\mathrm{C})$ & - & - & $2(\mathrm{~S} / \mathrm{C})$ & $1(\mathrm{C})$ & $1(\mathrm{C})$ & 6 \\
\hline & $\mathrm{AB} 2$ & - & $1(\mathrm{I})$ & - & $1(\mathrm{C})$ & - & - & $2(\mathrm{~S} / \mathrm{C})$ & $1(\mathrm{C})$ & - & 4 \\
\hline & $\mathrm{AB} 3$ & - & $1(\mathrm{I})$ & - & $1(\mathrm{C})$ & - & - & $2(\mathrm{~S} / \mathrm{C})$ & $1(\mathrm{C})$ & - & 4 \\
\hline & $\mathrm{AB} 4$ & $1(\mathrm{~S})$ & $1(\mathrm{I})$ & $1(\mathrm{~S})$ & $1(\mathrm{C})$ & - & - & $1(\mathrm{~S})$ & $1(\mathrm{C})$ & - & 6 \\
\hline & AB5 & $1(\mathrm{I})$ & 1(I) & $1(\mathrm{~S})$ & $1(\mathrm{C})$ & - & - & $1(\mathrm{~S})$ & $1(\mathrm{C})$ & - & 6 \\
\hline & AB6 & - & 1(I) & $1(\mathrm{~S})$ & $1(\mathrm{C})$ & $1(\mathrm{C})$ & - & $2(\mathrm{~S} / \mathrm{C})$ & $1(\mathrm{C})$ & - & 7 \\
\hline & $\mathrm{AB} 7$ & 1(I) & $1(\mathrm{I})$ & $1(\mathrm{~S})$ & $1(\mathrm{C})$ & $1(\mathrm{C})$ & - & $2(\mathrm{~S} / \mathrm{C})$ & $1(\mathrm{C})$ & - & 7 \\
\hline \multirow{5}{*}{ Verde } & AV1 & $2(\mathrm{I} / \mathrm{C})$ & $2(\mathrm{I} / \mathrm{C})$ & - & - & - & - & $1(\mathrm{~S})$ & - & - & 3 \\
\hline & AV2 & $2(\mathrm{I} / \mathrm{C})$ & $2(\mathrm{I} / \mathrm{C})$ & - & - & - & - & - & - & - & 2 \\
\hline & AV3 & - & $2(\mathrm{I} / \mathrm{C})$ & - & - & - & - & $1(\mathrm{~S})$ & - & - & 2 \\
\hline & AV4 & $3(\mathrm{~S} / \mathrm{I} / \mathrm{C})$ & $2(\mathrm{I} / \mathrm{C})$ & - & - & - & - & $1(\mathrm{~S})$ & - & - & 3 \\
\hline & AV5 & $3(\mathrm{~S} / \mathrm{I} / \mathrm{C})$ & $2(\mathrm{I} / \mathrm{C})$ & - & - & - & - & $1(\mathrm{~S})$ & - & - & 3 \\
\hline \multirow{3}{*}{ Rafael } & AR1 & 2(I/C) & $2(\mathrm{I} / \mathrm{C})$ & - & - & - & - & 2(I/C) & - & - & 3 \\
\hline & AR2 & $2(\mathrm{I} / \mathrm{C})$ & $2(\mathrm{I} / \mathrm{C})$ & - & - & - & - & $1(\mathrm{~S})$ & - & - & 3 \\
\hline & AR3 & $2(\mathrm{I} / \mathrm{C})$ & $2(\mathrm{I} / \mathrm{C})$ & - & - & - & - & $1(\mathrm{~S})$ & - & - & 3 \\
\hline \multicolumn{2}{|c|}{$\begin{array}{l}\text { Total of altered } \\
\text { measures for each } \\
\text { metal (N 72) }\end{array}$} & 26 & 33 & 06 & 16 & 04 & 01 & 36 & 15 & 04 & \\
\hline
\end{tabular}

Al-Aluminum, As-Arsenic, Barium, Cd-Cadmium, Cu-Copper, Cr-Chromium, Fe-Iron, Hg-Mercury, Lead-Pb / * Collected in triplicate / ** Collected in duplicate. S-dry period; I-intermediate period; Crainfall period, (-) Below the maximum allowable limit or limit of detection of quantification.

Chromium was the element with the lowest percentage of change in relation to the other metals whose values were above the MPV. Only in the drought period, at a single point (AP4) in Aldeia Pradinho, were values detected above those recommended (Table 2). The value (56.97 $\mu \mathrm{g} / \mathrm{L}$ ) was nearly $14 \%$ above the acceptable value in waters used for human consumption (50 $\mu \mathrm{g} / \mathrm{L})$. Regarding iron concentrations, values $(88,664.74 \mu \mathrm{g} / \mathrm{L})$ were observed in the dry period 295 times higher than allowed $(300 \mu \mathrm{g} / \mathrm{L})$. Of 24 evaluated points, 23 had values above the MPV (Table 2). In the intermediate period, in relation to seasonality, values levels remained within the acceptable range. Only $8 \%$ of the samples had values above the MPV. The greatest 
alterations were observed in the dry period, both in relation to the percentage of collections with values above that recommended $(91.6 \%)$ and in relation to their maximum values.

Copper had values changed (above $9 \mu \mathrm{g} / \mathrm{L}$ for surface water and $2000 \mu \mathrm{g} / \mathrm{L}$ for underground water) in four of the 24 analyzed points. Those alterations were only identified in Pradinho and Água Boa Villages (Table 2) and in surface waters (Table 4). These villages are geographically close, sharing the same climatic and geological conditions. Concerning arsenic, all collection points presented alterations in relation to MPV $(10 \mu \mathrm{g} / \mathrm{L})$ in the intermediate period. In the rainy season, this change was smaller, $37.5 \%$ of the samples obtained in two villages (Aldeia Verde and Rafael). During the dry season, the arsenic was within the recommended limits. Concerning concentration, the highest and lowest values were observed in the intermediate period, with a minimum of 13 times and a maximum of 18 times higher than VMP.

Barium presented altered concentrations (above $70 \mu \mathrm{g} / \mathrm{L}$ for surface water and $700 \mu \mathrm{g} / \mathrm{L}$ for groundwater) in six of the 24 points, two in Aldeia Pradinho (AP4 and AP5) and four in Aldeia Água Boa (AB4-AB7), in surface water samples with predominance in the dry period (Table 4). The concentrations of cadmium were altered, with values close to the MPV, in all points of Aldeia Pradinho and Água Boa in the rainy season. The values were within the limits $(1 \mu \mathrm{g} / \mathrm{L}$ for surface water and $5 \mu \mathrm{g} / \mathrm{L}$ for groundwater) in the dry and intermediate periods (Table 2). Concerning lead, changes were observed in four of the 24 points, especially Aldeia Pradinho, where $75 \%$ of collections were found with values higher than recommended (Table 2). In the dry period, there was the highest value of lead $(52.16 \mu \mathrm{g} / \mathrm{L})$, being more than five times higher than allowed $(10 \mu \mathrm{g} / \mathrm{L})$. In the intermediate period, the values of lead were within the limits allowed by the legislation, while in the rainy season this change in relation to MPV was identified at points $\mathrm{AP} 1$ and $\mathrm{AB} 1$. Additionally, mercury presented altered concentrations (above $0.2 \mu \mathrm{g} / \mathrm{L}$ for surface water and $1 \mu \mathrm{g} / \mathrm{L}$ for groundwater) in fifteen of the 24 assessed points in the rainy season, identified in Pradinho and Água Boa Villages. There was no evaluation of the mercury in the dry period, due to calibration problems for this element, during the processing of the sample.

In general, the analysis of the metals showed different results when considering the seasonality. In the dry period, six $(54.5 \%)$ of the 11 studied metals had changes in their concentrations in relation to MPVs. In the rainy season, an even greater change was identified, seven $(63.6 \%)$ of the studied metals were above the MPV. The lowest percentage change occurred in the intermediate period with three $(27.2 \%)$ change of the evaluated metals. The major changes in relation to seasonality were evident for arsenic in the intermediate period, for iron in the dry period and for cadmium in the rainy season. Chromium and barium showed concentrations above those permitted only in the dry period and mercury and cadmium only in the rainy season. Aluminum was detected at high concentrations in all periods of collection; however, in the dry period, its percentage of alteration was lower. The opposite was observed for iron, which presented unusual concentrations in all collected samples in the dry season (Table 3).

In Aldeia Pradinho, the AP4, AP5 and AP6 points presented the greatest changes. The Umburana River (AP4) had its most critical moment in the dry period and presented a lower concentration of the metals which were analyzed in the intermediate period. In Aldeia Água Boa, the most affected points were AB6 and AB7 in the rainy season (Table 2). The AV3 point (artesian well / reservoir health station) in Aldeia Verde was the best-evaluated regarding the quantification of the metals, not necessarily in relation to the toxicity of the evaluated metal (Table 2). 
Table 3. Number and percentage of samples with metals concentration higher than permitted for consumption per seasonal period in the Maxakali Villages, Minas Gerais, Brazil.

\begin{tabular}{lcccccc}
\hline \multirow{2}{*}{ Metals } & \multicolumn{2}{c}{ Dry } & \multicolumn{2}{c}{ Intermediate } & \multicolumn{2}{c}{ Rainy } \\
\cline { 2 - 7 } & $\mathbf{n}(\boldsymbol{\%})$ & Min/Max & $\mathbf{n}(\%)$ & Min/Max & $\mathbf{n}(\%)$ & Min/Max \\
\hline Aluminum & $5(21)$ & $178.9 / 49206$ & $11(46)$ & $100.09 / 158.4$ & $10(42)$ & $102.6 / 424.2$ \\
Arsenic & - & - & $24(100)$ & 143.6182 .1 & $9(37.5)$ & $15.3 / 169.4$ \\
Barium & $6(25)$ & $14.6 / 956.5$ & - & - & - & - \\
Cadmium & - & - & - & - & $16(67)$ & $5.07 / 5.15$ \\
Lead & $2(8)$ & $19.3 / 52.1$ & - & - & $2(8)$ & $11.4 / 12.5$ \\
Copper & $1(4)$ & 37.88 & - & - & $3(12)$ & $11.04 / 13.7$ \\
Chrome & $1(4)$ & 56.9 & - & - & - & - \\
Iron & $22(22)$ & $303.4 / 88664.7$ & $2(8)$ & $662.2 / 2551.1$ & $12(50)$ & $323.9 / 21849.9$ \\
Mercury* & - & - & - & - & $15(62)$ & $2.8 / 17.9$ \\
\hline
\end{tabular}

$\mathrm{n}$ - Number of collections with values higher than recommended, Min - minimum value observed in the samples, Max - maximum value observed in the samples, (-) number below the maximum permissible limit or limit of quantification, * Not evaluated in the dry period.

When comparing to MPVs, concerning water origin (surface or groundwater), we detected increased levels of barium, chromium and copper in surface water. Iron, arsenic, cadmium and mercury presented altered concentrations in both surface and underground waters. Aluminum presented concentrations over those allowed in $100 \%$ of the surface sources and in $25 \%$ of the underground sources. The four observed changes for lead were the same in surface and groundwater. When compared to the average concentration of metals in surface and groundwater, it was observed that aluminum, barium, arsenic and lead had much significantly higher concentrations in surface water sources, while cadmium and mercury concentrations were significantly higher in sources of groundwater (Table 4).

Table 4. Average values found in the analysis of metals in $\mu \mathrm{g} / \mathrm{L}$ by source of water in Maxakali villages, Minas Gerais, Brazil.

\begin{tabular}{|c|c|c|c|c|c|c|c|c|c|}
\hline \multirow{2}{*}{ Metal } & \multicolumn{5}{|c|}{ Source of the spring } & \multicolumn{3}{|c|}{$\begin{array}{l}\text { Maximum Allowable } \\
\text { Value }(\mu \mathrm{g} / \mathrm{L})\end{array}$} & \multirow{2}{*}{ P-Value } \\
\hline & Sup & $\begin{array}{l}\text { Standard } \\
\text { deviation }\end{array}$ & Sub & $\begin{array}{l}\text { Standard } \\
\text { deviation }\end{array}$ & Min/Max & Sup & Sup/Sub & Sub & \\
\hline Al & 1642.96 & 4376.3 & 49.92 & 41.38 & $-15.2 / 16451$ & 100 & - & 200 & $0.045^{*}$ \\
\hline $\mathrm{Cr}$ & 20.27 & 5.08 & 15.30 & 2.79 & $12.05 / 32.49$ & - & 50 & - & 0.117 \\
\hline $\mathrm{Fe}$ & 5156.28 & 8250.5 & 2139.8 & 2253.2 & $-27.7 / 29803$ & - & 300 & - & 0.062 \\
\hline Co & -10.48 & 7.55 & -7.43 & 5.37 & $-17.3 / 6.91$ & 9 & - & 2000 & 0.067 \\
\hline As & 78.07 & 22.75 & 58.46 & 14.39 & $47.95 / 104.51$ & - & 10 & - & $<0.001 *$ \\
\hline Cd & -0.6181 & 0.974 & 0.3340 & 0.763 & $-1.56 / 1.10$ & 1 & - & 5 & $0.006^{*}$ \\
\hline Ba & 61.86 & 87.31 & 46.91 & 15.70 & $13.64 / 333.91$ & 70 & - & 700 & $0.037 *$ \\
\hline Le & 1.56 & 6.26 & 0.9430 & 1.33 & $-2.47 / 19.95$ & - & 10 & - & $0.028 *$ \\
\hline Mc & -12.99 & 9.63 & -6.83 & 6.17 & $-22.43 /-2.11$ & 0.2 & - & 1 & $<0.001 *$ \\
\hline
\end{tabular}

$\mathrm{Al}$ (Aluminum), $\mathrm{Cr}$ (Chrome), $\mathrm{Fe}$ (Iron), Co (Copper), As (Arsenic), Cd (Cadmium), Ba (Barium), $\mathrm{Pb}$ (Lead) and $\mathrm{Hg}$ (Mercury). Sup: water from surface sources, Sub: waters from underground sources. Minminimum observed value, Max-maximum observed value, * Statistical significance for P-value $>95 \%$. Maximum value allowed in relation to Ministry of Health ordinances 2914/2011, CONAMA 357 and 396.

The Maxakali villages with the LOWER quality of waters for consumption in relation to the percentage of alteration in metal concentrations were Aldeia Pradinho (100\%), followed by Aldeia Água Boa (92\%); however, Aldeia Verde and Aldeia Rafael had the best evaluations (27\%). The samples with the highest alterations in relation to MPV were iron (50\%) followed 
by arsenic (46\%), aluminum (36\%), cadmium (22\%) and mercury (20\%). Barium (8.3\%), lead and copper $(5.5 \%)$ and chromium (1.3\%) presented lower percentages. Aluminum, barium, arsenic and lead showed significantly higher concentrations in surface water sources, but concentrations of cadmium and mercury were significantly higher in groundwater sources. Seasonality showed that the rainy season is the one with the highest percentage of collections with values higher than recommended, although their difference in relation to the dry period was small. The sources of water of superficial origin were those ones that presented the largest number of altered analyses, for being less protected. Based on these findings, our study identified high concentrations of toxic metals in the water consumed by the Maxakali indigenous community in Brazil.

The Northeastern region of the state of Minas Gerais has in its lithological area archeanoproterozoic rocks with varied metamorphic degree, with emphasis on lithologies of the Espinhaço Supergrupo and Grupo Macaúbas to the west. Its climate is tropical with the predominance of little rain and high temperatures. The Maxakali indigenous land has as main soil type the dystrophic yellow red podzolic, with some inclusions of shallow littoral soils and rock outcrops. The metals that were found in surface or groundwater may be the result of geochemical processes, of the decomposition of rocks and their weathering, and of natural characteristics such as the atmosphere, rainfall, and soil where they are located. That is why they are present in areas with low anthropogenic activity as suggested by the study. Artificially, its appearance is linked to anthropic sources of industrial, agricultural, mining, urban sewage and other unusual activities near the villages, except for the presence of urban sewage.

The cumulative power of some types of metal elements in human tissues causes their excess in drinking water to pose a serious risk to cellular physiological balance (Santos et al., 2006). Iron, like the other studied metals, has toxic potential from the maximum limit established for consumption. However, for this metal, such limit has been questioned because of the geological characteristics of the Brazilian soil that contain high concentrations that contaminate the aquifers (Carvalho, 2000). Its consumption above the limit value does not seem to have a physiological impact, since the amount required in one day by the human body (5-6 milligrams) would correspond to a consumption of 17 to 20 liters in the concentrations of 0.3 ppm, although its excess may increase the incidence of hematological problems, for example (Brewer, 2009). It is easy to find iron mainly in groundwater due to the dissolution of the ore by the carbon dioxide of the water, a characteristic not confirmed in this study, being justified by the geochemistry of the region. Blanc et al. (2013) obtained similar findings studying waters of rivers that are part of the same watershed. In this sense, high concentrations of iron were possibly responsible for the failure of attempts at chlorination in the water of Aldeia Pradinho according to information from local sanitation authorities.

Exposures to arsenic may occur through air, water and food, and values above the acceptable may be associated with the geological characteristics of rocks. In addition, insecticides, herbicides, fungicides, paints and products used to preserve wood are the main artificial sources for this element (Burguera and Burguera, 1993). The toxic potential of arsenic is dependent on the form of presentation in the middle, being a limitation in our study, since we didn't analyze its form of presentation.

In Brazil, studies evaluating the concentration of aluminum in waters of indigenous communities are scarce, although studies in river waters in the watershed region where the villages are located have found high concentrations for this element (Blanc et al., 2013). Regarding cadmium, a natural constituent of oceanic waters and of the earth crust, appears naturally in places that contain other elements such as zinc, lead and copper (Lalor, 2008). Its concentration in the water is naturally low and altered by anthropic conditions. Our findings identified such tendency in the rainy season with values close to the MPV.

The mercury comes from the degradation of the Earth's crust from volcanic eruptions, 
natural evaporation and mercury mines. It is generally associated with other elements and their anthropic sources are diversified (Horvat et al., 1996). Its organic form is the most toxic one and causes damage to human health. The indigenous and coastal communities that consume a lot of fish, present greater exposure to mercury (Lebel et al., 1998). Although some researchers have shown high levels of mercury in Amazonian indigenous populations (Santos et al., 2003), our study was limited to quantify their presence in the water consumed, without evaluating the concentration in the population who lives in the studied areas and its possible repercussion to those people's health.

Depending on the leach content of rocks, barium occurs naturally in surface and groundwater, and its artificial appearance is a result of mining activities and treatment of barium ores, burning of fossil fuels, purification of barite, and use of various insecticides (Mertz, 2012). In our study, the appearance of concentrations above that allowed for human consumption seems to be justified by natural conditions related to soil, which does not limit its potential for toxicity. Lead occurs naturally in small concentrations in the Earth's crust. It can also travel long distances in the air and contaminate areas with little anthropic activity (Patrick, 2006). Even appearing in a lower percentage in this study, it deserves special attention considering its high toxicity. We did not observe anthropic characteristics that could justify the alterations for this element, even though most of the findings showed values close to that recommended. New studies are suggested for the evaluation of this element.

As we know, copper and chromium are widely distributed in nature and it can be found in rocks, soil, water and air. In low doses, copper is essential to health (Gaetke and Chow, 2003). However, the exposure to high levels of copper causes irritation of the mouth, eyes and nose, as well as gastrointestinal distress and death (Santos, 2015). Its artificial appearance in the environment is related to its use in agriculture, in the treatment of water, and in forest fires (Flemming and Trevors, 1989). There was a coincidence of collections with some fires in the forests of Maxakali villages, which may justify the appearance of this element in higher concentrations in the water which was evaluated.

To our knowledge, this is the first study to address the concentration of metals in waters for human consumption in this population group. Although there is no record of hospital admissions due to causes associated with metal toxicity (Brasil, 2015), such absence does not necessarily imply non-existence. Toxicity is characterized by nonspecific symptoms; effects of low doses are underestimated and there is a lack of infrastructure to diagnose possible intoxications. In addition, some social determinants with an isolation in regions distant from access to mass public policies, associated with specific cultural characteristics, place indigenous groups in a condition of high vulnerability (Marmot, 2007).

The indigenous health needs, individual or collective, are influenced by biological, cultural, economic, political and social variables (Nakamura et al., 2009), which causes the impact of vulnerability in facing the differences. Thus, both extrinsic and intrinsic vulnerability present in these groups can promote biological inequalities in health compared to other, less vulnerable groups (Rogers and Ballantyne, 2008). In this sense, it is possible to infer that high concentrations of toxic elements can produce different results in the human organism, depending on the degree of vulnerability to which the receptor is subjected, because the organic response to the aggressive agent may be dependent on biological conditions that should be equal, but that vulnerability makes it different.

Health teams at both local and regional level should be aware of possible clinical symptoms related to poisoning processes by these metals. Health promotion and prevention of diseases, however, cannot wait for symptoms and clinical signs to realize that the water consumed is toxic, especially in places where access to health services is limited. Our study aims to identify the a priori risk and points out the need to establish proposals and measures to minimize risks related to the supply of this water, to be offered by the sanitation team together with responsible 
authorities, taking into consideration the quality of water and the capacity of each point in meeting those local needs. The principle of integrality of caring presupposes that managers also care about the effects of actions on the environment and how to minimize exposure to risk, especially in the context of highly vulnerable populations.

The cultural relationship of the Maxakali people with water, the lack of distinction between contact and consumption and the constant mobility between villages, favors consumption at more critical points, not guaranteeing the absence of risk, even in villages with better indicators. Moreover, because of their cumulative power in plants and aquatic animals, toxic metals can pose a health risk in groups dependent on this food base (Melville and Burchett, 2002). Although our study has presented a worrying scenario regarding the water consumed by Maxakali population, the non-identification of the presentation of some metals makes it difficult to associate them with the risks represented by elements whose absorption and bioavailability depends on this chemical form. Finally, we emphasize that our findings have a scientific importance; however, they must be interpreted in light of the relative limitations in the performance some risk analyses and in analyzing the metal concentrations by the type of water source. This was not possible and indicated considering the logistics of the study, and because the Maxakali indigenous community showed no differentiation in relation to water consumption, justifying the classification of all water sources as Type I accordingly the CONAMA 375/2005 resolution in our study.

\section{CONCLUSIONS}

This study identified high concentrations of toxic metals in the water consumed by the Maxakali indigenous community in Brazil. Due to the higher concentrations for iron, arsenic, aluminum, cadmium and mercury observed in this study, the monitoring of these elements is advisable, besides a generalized identification of their origin. It is also recommended that they be evaluated at smaller intervals in relation to different sources, seasonality and bioavailability of each metal. In addition, it is necessary to search for new water sources with better conditions for this population, besides immediate intervention concerning sources with more critical indicators.

\section{REFERENCES}

ASSIS, E. M.; OLIVIERIA, R. C.; MOREIRA, L. E.; PENA, J. L.; RODRIGUES, L. C.; MACHADO-COELHO, G. L. L. Prevalência de parasitos intestinais na comunidade indígena Maxakali, Minas Gerais, Brasil, 2009. Cadernos de Saúde Pública, v. 29, n. 4, p. 681-690, 2013. http://dx.doi.org/10.1590/S0102-311X2013000400006

BLANC, L. R.; MOREIRA, F. S.; GONÇALVES, A. M.; MANCHESTER, R. S.; BARONI, L.; FARIA, M. C. et al. Contamination in a brazilian river: a risk of exposure to untreated effluents. Journal of Environmental Quality, v. 42, n. 5, p. 1596-1601, 2013. http://dx.doi.org/10.2134/jeq2013.02.0068

BOLLMANN, H. A.; MARQUES, D. M. Bases para a estruturação de indicadores de qualidade de águas. Revista Brasileira de Recursos Hídricos, v. 5, n. 1, p. 37-60, 2000. http://dx.doi.org/10.21168/rbrh.v5n1.p37-60 
BORGES, J. D. B.; ALARCÓN, R. S. R.; AMATO NETO, V.; GAKIYA, E. Parasitoses intestinais de indígenas da comunidade Mapuera (Oriximiná, Estado do Pará, Brasil): elevada prevalência de Blastocystis hominis e encontro de Cryptosporidium sp e Cyclospora cayetanensis. Revista da Sociedade Brasileira de Medicina Tropical, v. 42, n. 3, p. 348-350, 2009. http://dx.doi.org/10.1590/S0037-86822009000300022

BRASIL. Ministério da Saúde. Sistema de Informação da Atenção à Saúde Indígena. 2015. Available in: http://portalsaude.saude.gov.br/index.php/oministerio/principal/secretarias/secretaria-sesai. Access in: Nov. 2016.

BREWER, G. J. Risks of copper and iron toxicity during aging in humans. Chemical Research in Toxicology, v. 23, n. 2, p. 319-326, 2009. http://dx.doi.org/10.1021/tx900338d

BURGUERA, M.; BURGUERA, J. L. Flow injection-electrothermal atomic absorption spectrometry for arsenic speciation using the Fleitmann reaction. Journal of Analytical $\begin{array}{lllllllll}\text { Atomic } & \text { Spectrometry, } & \text { v. } & 8, & \text { n. } & 2, & \text { p. } & 229-233,\end{array}$ http://dx.doi.org/10.1039/C7JA00275K

CARVAlHO, A. R. Processo de complexação do ferro em águas subterrâneas. Uma proposta de mudança da portaria 36 do Ministério da Saúde. Guarulhos: UnG, 2000.

COMPANHIA AMBIENTAL DO ESTADO DE SÃO PAULO - CETESB. Guia nacional de coleta e preservação de amostras: água, sedimento, comunidades aquáticas e efluentes líquidos. São Paulo: CETESB; Brasília: ANA, 2011.

DERISIO, J. C. Introdução ao controle da poluição ambiental. São Paulo, 1992.

FLEMMING, C. A.; TREVORS, J. T. Copper toxicity and chemistry in the environment: a review. Water, Air, \& Soil Pollution, v. 44, n. 1, p. 143-158, 1989. http://dx.doi.org/10.1007/BF00228784

GAETKE, L. M.; CHOW, C. K. Copper toxicity, oxidative stress, and antioxidant nutrients. Toxicology, v. 189, n. 1, p. 147-163, 2003. http://dx.doi.org/10.1016/S0300483X(03)00159-8

HORVAT, M. Mercury analysis and speciation in environmental samples. In: Global and regional mercury cycles: sources, fluxes and mass balances. In: BAEYENS, W.; EBINGHAUS, R.; VASILIEV, O. (Eds.). Netherlands: Springer, 1996. p. 1-31. http://dx.doi.org/10.1007/978-94-009-1780-4

LALOR, G. C. Review of cadmium transfers from soil to humans and its health effects in the Jamaican environment. Science of the Total Environment, v. 400, n. 1, p. 162-172, 2008. http://dx.doi.org/10.1016/j.scitotenv.2008.07.011

LAWRENCE, M. G.; GREIGA A.; COLLERSONA, K. D.; KAMBERA, B. S. Direct quantification of rare earth element concentrations in natural waters by ICP-MS. Applied $\begin{array}{lllllll}\text { geochemistry, } & \text { v. } & 21, & \text { n. } & 5, & \text { p. } & 839-848,\end{array}$ http://dx.doi.org/10.1016/j.apgeochem.2006.02.013

LEBEL, J.; MERGLER, D.; BRANCHES, F.; LUCOTTE, M.; AMORIM, M.; LARRIBE, F. et al. Neurotoxic effects of low-level methylmercury contamination in the Amazonian Basin. Environmental research, v. 79, n. 1, p. 20-32, 1998. http://dx.doi.org/10.1006/enrs.1998.3846

MARMOT, M. Achieving health equity: from root causes to fair outcomes. The Lancet, v. 370, n. 9593, p. 1153-1163, 2007. http://dx.doi.org/10.1016/S0140-6736(07)61385-3 
MELVILLE, F.; BURCHETT, M. Genetic variation in Avicennia marina in three estuaries of Sydney (Australia) and implications for rehabilitation and management. Marine Pollution Bulletin, v. 44, n. 6, p. 469-479, 2002. http://dx.doi.org/10.1016/S0025326X(01)00259-4

MERTZ, W. Trace elements in human and animal nutrition. Volume 2. [S.l.]: Elsevier, 2012.

NAKAMURA, E.; EGRY, E. Y.; CAMPOS, C. M. S.; NICHIATA, L. Y. I.; CHIESA, A. M.; TAKAHASHI, R. F. The potential of an instrument to identify social vulnerabilities and health needs: collective health knowledge and practices. Revista Latino-Americana de Enfermagem, v. 17, n. 2, p. 253-258, 2009. http://dx.doi.org/10.1590/S010411692009000200018

PATRICK, L. Lead toxicity, a review of the literature. Part 1: Exposure, evaluation, and treatment. Alternative Medicine Review, v. 11, n. 1, p. 2-22, 2006.

PRUSZKOWSKI, E.; BOSNAK, C. The Analysis of Drinking Waters by U. S. EPA Methods 200.8 Using the NexION 300Q/350Q ICP-MS in Standard Mode. Waltham: Perkin-Elmer, 2012.

ROGERS, W.; BALLANTYNE, A. Special populations: vulnerability and protection. Electronic Journal of Communication Information \& Innovation in Health, v. 2, n. Sup.1, p. 30-40, 2008. http://dx.doi.org/10.3395/reciis.v2.Sup1.207en

SANTOS, D. M.; BOSSINI, J. A. T.; PREUSSLER, K. H.; VASCONSELOS, E. C.; CARVALHO-NETO, F. S.; CARVALHO-FILHO, M. A. S. Avaliação de metais pesados na baía de Paranaguá, PR, Brasil, sob influência das atividades antrópicas. Journal of the Brazilian Society of Ecotoxicology, v. 1, n. 2, p. 157-160, 2006. http://dx.doi.org/10.5132/jbse.2006.02.013

SANTOS, E. C. O.; CÂMARA, V. M.; BRABO, E. S.; LOUREIRO, E. C. B.; JESUS, I. M.; FAYAL, K.; SAGICA, F. Avaliação dos níveis de exposição ao mercúrio entre índios Pakaanóva, Amazônia, Brasil. Cadernos de Saúde Pública, v. 19, n. 1, p. 199-206, 2003. http://dx.doi.org/10.1590/S0102-311X2003000100022

SANTOS, L. T. S. O. Caracterização de metais pesados das águas superficiais da bacia do Rio Subaé (Bahia). Geochimica Brasiliensis, v. 28, n. 2, p. 137-148, 2015. http://dx.doi.org/10.5327/Z0102-9800201400020003 
Table S1. Collection points, abbreviations, classification in terms of water source and geodetic coordinates.

\begin{tabular}{|c|c|c|c|c|}
\hline Description of the place & Abbreviation & Origin & Latitude & Longitude \\
\hline Well of capture Aldeia Vila Nova & AP1 & Groundwater & $16,53,10.7$ & $40,32,38.0$ \\
\hline Reservoir Aldeia Vila Nova & AP2 & Groundwater & $16,52,36.3$ & $40,33,56,6$ \\
\hline End of water network-Faucet-Posto Vila Nova & AP3 & Groundwater & $16,53,04.9$ & $40,32,36.4$ \\
\hline Umburana River & AP4 & Surface & $16,52,51.5$ & $40,32,26.8$ \\
\hline Stream Aldeia João Mineiro & AP5 & Surface & $16,53,03.7$ & $40,33,02.4$ \\
\hline Stream Aldeia Maravilha & AP6 & Surface & $16,52,28.0$ & $40,34,10.4$ \\
\hline Well of capture Aldeia Cachoeira & AP7 & Groundwater & $16,52,21.7$ & $40,34,16.1$ \\
\hline Reservoir Aldeia Cachoeira & AP8 & Groundwater & $16,52,04.4$ & $40,34,33.4$ \\
\hline End of water -Faucet-Aldeia Maravilha & AP9 & Groundwater & $16,52,36.3$ & $40,34,05.2$ \\
\hline Well of capture Principal-Riacho & AV1 & Surface & $17,37,45.28$ & $41,44,59.74$ \\
\hline Reservoir-Filtro Lento & AV2 & Surface & $17,37,42.27$ & $41,44,59.17$ \\
\hline Well/ Reservoir Health Post & AV3 & Groundwater & $17,37,40.70$ & $41,44,49.85$ \\
\hline End of water network-Faucet - Pinheiro School & AV4 & Surface 1 & $17,37,42.11$ & $41,44,57.08$ \\
\hline Lagoon & AV5 & Surface 1 & $17,37,43.29$ & $41,44,48.29$ \\
\hline Well of capture Aldeia Agua Boa & $\mathrm{AB} 1$ & Groundwater & $16,53,29.8$ & $40,36,13.4$ \\
\hline Reservoir Aldeia Agua Boa & AB2 & Groundwater & $16,53,08.7$ & $40,36,14.3$ \\
\hline End of water network-Faucet -Aldeia Pirino & AB3 & Groundwater & $16,52,28.7$ & $40,36,16.0$ \\
\hline Stream Aldeia João Bidé & $\mathrm{AB} 4$ & Surface & $16,52,35.1$ & $40,36,16.9$ \\
\hline Spring Agua Boa River & AB5 & Surface & $16,53,26.58$ & $40,36,54.19$ \\
\hline Stream Agua Boa- Ponte de Cimento & AB6 & Surface & $16,53,28.6$ & $40,36,51.9$ \\
\hline End of water-Spring A. Boa-Aldeia Luizinha & $\mathrm{AB} 7$ & Surface & $16,53,12.0$ & $40,36,52.6$ \\
\hline Lagoon Captation & AR1 & Surface & $17,56,35,0$ & $41,26,28,6$ \\
\hline Reservoir with Slow Filter & AR2 & Surface & $17,56,55,5$ & $41,26,30.7$ \\
\hline End of water network- Faucet last House & AR3 & Surface & $17,56,48.12$ & $41,26,54.24$ \\
\hline
\end{tabular}

Abbreviations: AP-Aldeia Pradinho, AB- Aldeia Água Boa, AV- Aldeia Verde (Ladainha) e ARAldeia Rafael (Topázio). 
Table S2. Metals with absolute concentrations in micrograms per liter $(\mu \mathrm{g} / \mathrm{L})$, in the three seasonal periods at twenty-four collection points in Maxakali Villages from January to July 2015.

\begin{tabular}{|c|c|c|c|c|c|c|c|c|c|c|c|c|c|c|c|}
\hline \multirow[t]{2}{*}{ Points } & \multicolumn{3}{|c|}{$\begin{array}{c}\text { Al (Aluminum) } \\
\text { VMP Sup:100 Sub: } 200\end{array}$} & \multicolumn{3}{|c|}{$\begin{array}{c}\text { Cr (Chromium) } \\
\text { VMP:50 }\end{array}$} & \multicolumn{3}{|c|}{$\begin{array}{l}\text { Fe (Iron) } \\
\text { VMP:300 }\end{array}$} & \multicolumn{3}{|c|}{$\begin{array}{c}\text { Cu (Copper) } \\
\text { VMP: Sup: 9 Sub: } 2000\end{array}$} & \multicolumn{3}{|c|}{$\begin{array}{c}\text { As (Arsenic) } \\
\text { VMP: } 10\end{array}$} \\
\hline & $1^{\mathrm{a}}$ & $2^{\mathrm{a}}$ & $3^{a}$ & $\mathbf{1}^{\mathrm{a}}$ & $2^{\mathrm{a}}$ & $3^{\mathrm{a}}$ & $\mathbf{1}^{\mathrm{a}}$ & $2^{\mathrm{a}}$ & $3^{\mathrm{a}}$ & $\mathbf{1}^{\mathrm{a}}$ & $2^{\mathrm{a}}$ & $3^{\mathrm{a}}$ & $\mathbf{1}^{\mathrm{a}}$ & $2^{a}$ & $3^{a}$ \\
\hline AP1* & $<\mathrm{LOQ}$ & 121,05 & 25,38 & $<\mathrm{LOQ}$ & 39,75 & 16,01 & $1088,97 \uparrow$ & $<\mathrm{LOQ}$ & $10725,24 \uparrow$ & $<$ LOQ & $<\mathrm{LOQ}$ & 9,19 & $<\mathrm{LOQ}$ & $167,01 \uparrow$ & $15,32 \uparrow$ \\
\hline AP2* & $<\mathrm{LOQ}$ & 100,43 & 12,42 & 2,72 & 33,92 & 10,6 & $1768,3 \uparrow$ & $<\mathrm{LOQ}$ & 39 & $<\mathrm{LOQ}$ & $<\mathrm{LOQ}$ & 3,4 & $<\mathrm{LOQ}$ & $154,41 \uparrow$ & 7,77 \\
\hline AP3* & $<\mathrm{LOQ}$ & 86,75 & 11,07 & $<\mathrm{LOQ}$ & 31,69 & 9,43 & $1015,51 \uparrow$ & $<\mathrm{LOQ}$ & 32,59 & $<$ LOQ & $<\mathrm{LOQ}$ & 2,33 & $<\mathrm{LOQ}$ & $146,6 \uparrow$ & 8,03 \\
\hline $\mathbf{A P 4}$ ** & $49206 \uparrow$ & 97,4 & 50,66 & $56,97 \uparrow$ & 30,99 & 9,5 & $88664,74 \uparrow$ & $<\mathrm{LOQ}$ & $959,96 \uparrow$ & $\mathbf{3 7 , 8 8} \uparrow$ & $<\mathrm{LOQ}$ & 3,18 & 4,84 & $147,41 \uparrow$ & 7,23 \\
\hline AP5** & $9018,45 \uparrow$ & $148,57 \uparrow$ & $269,22 \uparrow$ & 7,93 & 43,67 & 9,76 & $43373,32 \uparrow$ & 118,94 & $2487,27 \uparrow$ & 8,57 & $<\mathrm{LOQ}$ & 3,28 & $<\mathrm{LOQ}$ & $178,36 \uparrow$ & 7,64 \\
\hline AP6** & 39,46 & $158,42 \uparrow$ & $124,31 \uparrow$ & $<\mathrm{LOQ}$ & 44,72 & 12,17 & $2382,9 \uparrow$ & 63,49 & 245,25 & $<\mathrm{LOQ}$ & $<\mathrm{LOQ}$ & $11,04 \uparrow$ & $<\mathrm{LOQ}$ & $182,11 \uparrow$ & 7,49 \\
\hline AP7* & $<\mathrm{LOQ}$ & 113,3 & 23,71 & $<\mathrm{LOQ}$ & 32,59 & 9,87 & $623,11 \uparrow$ & $2551,11 \uparrow$ & $929,66 \uparrow$ & $<\mathrm{LOQ}$ & $<\mathrm{LOQ}$ & 3,35 & $<\mathrm{LOQ}$ & $138,27 \uparrow$ & 7,39 \\
\hline AP8* & $<\mathrm{LOQ}$ & 110,77 & 63,92 & 2,03 & 33,18 & 11,14 & $7409,94 \uparrow$ & $<\mathrm{LOQ}$ & $\mathbf{8 9 9 , 7 3 \uparrow}$ & 20,48 & $<\mathrm{LOQ}$ & 10,7 & 2,02 & $147,54 \uparrow$ & 7,47 \\
\hline AP9* & $<\mathrm{LOQ}$ & 120,03 & 19 & $<\mathrm{LOQ}$ & 36,61 & 12,28 & $2896,71 \uparrow$ & 105,04 & $2097,46 \uparrow$ & $<\mathrm{LOQ}$ & $<\mathrm{LOQ}$ & 12,16 & $<\mathrm{LOQ}$ & $158,87 \uparrow$ & 7,5 \\
\hline AB1* & $<\mathrm{LOQ}$ & 136,26 & $424,29 \uparrow$ & $<\mathrm{LOQ}$ & 42,1 & 10,34 & $1317,48 \uparrow$ & 98,17 & $21849,92 \uparrow$ & $<\mathrm{LOQ}$ & $<\mathrm{LOQ}$ & 9,25 & $<\mathrm{LOQ}$ & $165,32 \uparrow$ & 7,44 \\
\hline AB2* & $<\mathrm{LOQ}$ & 92,4 & 171,69 & $<\mathrm{LOQ}$ & 33,53 & 9,82 & $1404,2 \uparrow$ & 36,66 & $959,91 \uparrow$ & $<\mathrm{LOQ}$ & $<\mathrm{LOQ}$ & 3,09 & $<\mathrm{LOQ}$ & $157,32 \uparrow$ & 7,26 \\
\hline AB3* & $<\mathrm{LOQ}$ & 104,93 & 142,91 & $<\mathrm{LOQ}$ & 36,86 & 9,72 & $1579,88 \uparrow$ & $<\mathrm{LOQ}$ & $696,48 \uparrow$ & $<\mathrm{LOQ}$ & $<\mathrm{LOQ}$ & 2,7 & $<\mathrm{LOQ}$ & $161,79 \uparrow$ & 7,19 \\
\hline $\mathbf{A B} 4 * *$ & $7238,83 \uparrow$ & 86,6 & 53,25 & 5,53 & 31,4 & 9,6 & $25078,13 \uparrow$ & $<\mathrm{LOQ}$ & 107,83 & $<\mathrm{LOQ}$ & $<\mathrm{LOQ}$ & 5,52 & $<\mathrm{LOQ}$ & $152,25 \uparrow$ & 7,06 \\
\hline $\mathbf{A B 5}^{* *}$ & $<\mathrm{LOQ}$ & $101,25 \uparrow$ & 4,51 & $<\mathrm{LOQ}$ & 34,58 & 9,62 & $1593,73 \uparrow$ & $<\mathrm{LOQ}$ & 76,6 & $<\mathrm{LOQ}$ & $<\mathrm{LOQ}$ & 6,59 & $<\mathrm{LOQ}$ & $155,26 \uparrow$ & 7,03 \\
\hline AB6** & $<\mathrm{LOQ}$ & 98,25 & 46,93 & $<\mathrm{LOQ}$ & 34,61 & 10,78 & $3029,34 \uparrow$ & $<\mathrm{LOQ}$ & $503,41 \uparrow$ & $<\mathrm{LOQ}$ & $<\mathrm{LOQ}$ & $11,44 \uparrow$ & $<\mathrm{LOQ}$ & $159,32 \uparrow$ & 7,05 \\
\hline $\mathbf{A B} 7 * *$ & $<\mathrm{LOQ}$ & $114,45 \uparrow$ & 32,76 & $<\mathrm{LOQ}$ & 39,81 & 10,96 & $1763,73 \uparrow$ & $<\mathrm{LOQ}$ & $323,96 \uparrow$ & $<\mathrm{LOQ}$ & $<\mathrm{LOQ}$ & $13,79 \uparrow$ & $<\mathrm{LOQ}$ & $166,8 \uparrow$ & 7,02 \\
\hline AV1** & $<\mathrm{LOQ}$ & $100,09 \uparrow$ & $146,83 \uparrow$ & $<\mathrm{LOQ}$ & 32,7 & 42,29 & $303,49 \uparrow$ & $<\mathrm{LOQ}$ & $<\mathrm{LOQ}$ & $<\mathrm{LOQ}$ & $<\mathrm{LOQ}$ & $<\mathrm{LOQ}$ & $<\mathrm{LOQ}$ & $146,52 \uparrow$ & $169,42 \uparrow$ \\
\hline AV2** & $<\mathrm{LOQ}$ & $103,55 \uparrow$ & $122,37 \uparrow$ & $<\mathrm{LOQ}$ & 32,41 & 34,45 & 270,12 & $<\mathrm{LOQ}$ & $<\mathrm{LOQ}$ & $<\mathrm{LOQ}$ & $<\mathrm{LOQ}$ & $<\mathrm{LOQ}$ & $<\mathrm{LOQ}$ & $143,66 \uparrow$ & $145,88 \uparrow$ \\
\hline AV3* & $<\mathrm{LOQ}$ & 133,49 & 112,7 & $<\mathrm{LOQ}$ & 33,94 & 33,89 & $4813,29 \uparrow$ & 112,61 & $<\mathrm{LOQ}$ & $<\mathrm{LOQ}$ & $<\mathrm{LOQ}$ & $<\mathrm{LOQ}$ & $<\mathrm{LOQ}$ & $152,6 \uparrow$ & $144,9 \uparrow$ \\
\hline AV4** & $828,39 \uparrow$ & $110,64 \uparrow$ & $102,69 \uparrow$ & $<\mathrm{LOQ}$ & 35,47 & 35,33 & $7340,97 \uparrow$ & $<\mathrm{LOQ}$ & $<\mathrm{LOQ}$ & $<\mathrm{LOQ}$ & $<\mathrm{LOQ}$ & $<\mathrm{LOQ}$ & $<\mathrm{LOQ}$ & $156,16 \uparrow$ & $154,86 \uparrow$ \\
\hline AV5** & $178,92 \uparrow$ & $108,32 \uparrow$ & $111,26 \uparrow$ & $<\mathrm{LOQ}$ & 33,49 & 34,84 & $13173,51 \uparrow$ & $<\mathrm{LOQ}$ & $<\mathrm{LOQ}$ & $<\mathrm{LOQ}$ & $<\mathrm{LOQ}$ & $<\mathrm{LOQ}$ & $<\mathrm{LOQ}$ & $151,65 \uparrow$ & $156,34 \uparrow$ \\
\hline AR1** & $<\mathrm{LOQ}$ & $106,99 \uparrow$ & $131,59 \uparrow$ & $<\mathrm{LOQ}$ & 34,97 & 35,98 & 82,19 & $662,2 \uparrow$ & $452,98 \uparrow$ & $<\mathrm{LOQ}$ & $<\mathrm{LOQ}$ & $<\mathrm{LOQ}$ & $<\mathrm{LOQ}$ & $145,44 \uparrow$ & $148,66 \uparrow$ \\
\hline $\mathbf{A R} 2 * *$ & 48,19 & $115,52 \uparrow$ & $109,99 \uparrow$ & $<\mathrm{LOQ}$ & 33,59 & 36,73 & $13252,56 \uparrow$ & 203,05 & 274,72 & $<\mathrm{LOQ}$ & $<$ LOQ & $<\mathrm{LOQ}$ & $<\mathrm{LOQ}$ & $144,73 \uparrow$ & $154,96 \uparrow$ \\
\hline AR3** & 25,16 & $114,2 \uparrow$ & $111,69 \uparrow$ & $<\mathrm{LOQ}$ & 34,84 & 35,54 & $12296,57 \uparrow$ & 48,67 & $<\mathrm{LOQ}$ & $<\mathrm{LOQ}$ & $<\mathrm{LOQ}$ & $<\mathrm{LOQ}$ & $<\mathrm{LOQ}$ & $144,25 \uparrow$ & $148,11 \uparrow$ \\
\hline
\end{tabular}

Rev. Ambient. Água vol. 14 n. 1, e2215 - Taubaté 2019 


\begin{tabular}{|c|c|c|c|c|c|c|c|c|c|c|c|c|c|c|c|c|c|}
\hline \multicolumn{18}{|c|}{ Continued... } \\
\hline \multirow[t]{2}{*}{ Points } & \multicolumn{3}{|c|}{$\begin{array}{l}\text { Se (Selenium) } \\
\text { VMP: } 10\end{array}$} & \multicolumn{3}{|c|}{$\begin{array}{l}\text { St (Strontium) } \\
\text { VMP: } 1000\end{array}$} & \multicolumn{3}{|c|}{$\begin{array}{c}\text { Cd (Cadmium) } \\
\text { VMP Sup: } 1 \text { Sub: } 5 \\
\end{array}$} & \multicolumn{3}{|c|}{$\begin{array}{c}\text { Ba (Barium) } \\
\text { VMP Sup: 70 Sub: } 700\end{array}$} & \multicolumn{3}{|c|}{$\begin{array}{l}\text { Pb (Lead) } \\
\text { VMP: } 10\end{array}$} & \multicolumn{2}{|c|}{$\begin{array}{c}\text { Hg (Mercury) } \\
\text { VMP: Sup: 0,2 Sub: } 1\end{array}$} \\
\hline & $1^{a}$ & $2^{a}$ & $3^{a}$ & $1^{a}$ & $2^{\mathrm{a}}$ & $3^{a}$ & $1^{a}$ & $2^{\mathrm{a}}$ & $3^{\mathrm{a}}$ & $\mathbf{1}^{\mathrm{a}}$ & $2^{\mathrm{a}}$ & $3^{a}$ & $1^{a}$ & $2^{\mathrm{a}}$ & $3^{a}$ & $1^{a}$ & $2^{\mathrm{a}}$ \\
\hline AP1* & $<\mathrm{LOQ}$ & $<\mathrm{LOQ}$ & 6,44 & 286,94 & 0,19 & 120,89 & $<\mathrm{LOQ}$ & $<\mathrm{LOQ}$ & $5,15 \uparrow$ & 50,88 & 4,23 & 61,8 & $<\mathrm{LOQ}$ & $<\mathrm{LOQ}$ & $11,47 \uparrow$ & $<\mathrm{LOQ}$ & $2,844 \uparrow$ \\
\hline AP2* & $<\mathrm{LOQ}$ & $<\mathrm{LOQ}$ & 5,96 & 260,79 & 24,47 & 84,84 & $<\mathrm{LOQ}$ & $<\mathrm{LOQ}$ & $5,09 \uparrow$ & 68,91 & 13,31 & 36,07 & $<\mathrm{LOQ}$ & $<\mathrm{LOQ}$ & 8,43 & $<\mathrm{LOQ}$ & 0,423 \\
\hline AP3* & $<\mathrm{LOQ}$ & $<\mathrm{LOQ}$ & 6,34 & 173,99 & 22,72 & 111,53 & $<\mathrm{LOQ}$ & $<\mathrm{LOQ}$ & $5,08 \uparrow$ & 50,98 & 11,83 & 41,99 & $<\mathrm{LOQ}$ & $<\mathrm{LOQ}$ & 8,38 & $<\mathrm{LOQ}$ & $17,9 \uparrow$ \\
\hline $\mathbf{A P 4} * *$ & $<\mathrm{LOQ}$ & $<\mathrm{LOQ}$ & 5,53 & 114,26 & 27,69 & 25,04 & $<$ LOQ & $<\mathrm{LOQ}$ & $5,09 \uparrow$ & $956,59 \uparrow$ & 14,6 & 30,54 & $52,16 \uparrow$ & $<\mathrm{LOQ}$ & 8,52 & $<\mathrm{LOQ}$ & $16,57 \uparrow$ \\
\hline AP5** & $<\mathrm{LOQ}$ & $<\mathrm{LOQ}$ & 6,32 & 90,1 & 2,75 & 68,98 & $<$ LOQ & $<\mathrm{LOQ}$ & $5,08 \uparrow$ & $391,1 \uparrow$ & 14,02 & 67,1 & $19,38 \uparrow$ & $<\mathrm{LOQ}$ & 8,61 & $<\mathrm{LOQ}$ & $15,64 \uparrow$ \\
\hline AP6** & $<\mathrm{LOQ}$ & $<\mathrm{LOQ}$ & 5,86 & 11,41 & 22,29 & 46,61 & $<\mathrm{LOQ}$ & $<\mathrm{LOQ}$ & $5,09 \uparrow$ & 18,46 & 34,31 & 29,25 & $<\mathrm{LOQ}$ & $<\mathrm{LOQ}$ & 8,73 & $<\mathrm{LOQ}$ & $15,24 \uparrow$ \\
\hline $\mathbf{A P 7} \mathbf{7}^{*}$ & $<\mathrm{LOQ}$ & $<\mathrm{LOQ}$ & 5,54 & 175,61 & 22,47 & 130,8 & $<$ LOQ & $<\mathrm{LOQ}$ & $5,09 \uparrow$ & 55,64 & 48,6 & 48,48 & $<\mathrm{LOQ}$ & $<\mathrm{LOQ}$ & 9,36 & $<\mathrm{LOQ}$ & $14,98 \uparrow$ \\
\hline AP8* & $<\mathrm{LOQ}$ & $<\mathrm{LOQ}$ & 6,04 & 131,25 & 31,25 & 166,29 & $<$ LOQ & $<\mathrm{LOQ}$ & $5,09 \uparrow$ & 61,35 & 14,53 & 56,72 & $<\mathrm{LOQ}$ & $<\mathrm{LOQ}$ & 9,05 & $<\mathrm{LOQ}$ & $14,85 \uparrow$ \\
\hline AP9* & $<\mathrm{LOQ}$ & $<\mathrm{LOQ}$ & 5,88 & 169,21 & 34,44 & 102,6 & $<$ LOQ & $<\mathrm{LOQ}$ & $5,07 \uparrow$ & 139,83 & 17,02 & 31,14 & $<\mathrm{LOQ}$ & $<\mathrm{LOQ}$ & 8,28 & $<\mathrm{LOQ}$ & $14,61 \uparrow$ \\
\hline AB1* & $<\mathrm{LOQ}$ & $<\mathrm{LOQ}$ & 5,46 & 11,4 & 16,21 & 68,86 & $<$ LOQ & $<\mathrm{LOQ}$ & $5,07 \uparrow$ & 19,61 & 21,81 & 205,95 & $<\mathrm{LOQ}$ & $<\mathrm{LOQ}$ & $12,52 \uparrow$ & $<\mathrm{LOQ}$ & $14,26 \uparrow$ \\
\hline$A B 2 *$ & $<\mathrm{LOQ}$ & $<\mathrm{LOQ}$ & 5,48 & 0,29 & 13,81 & 64,81 & $<$ LOQ & $<\mathrm{LOQ}$ & $5,07 \uparrow$ & 14,6 & 36,59 & 77,44 & $<\mathrm{LOQ}$ & $<\mathrm{LOQ}$ & 8,26 & $<\mathrm{LOQ}$ & $14,16 \uparrow$ \\
\hline AB3* & $<$ LOQ & $<$ LOQ & 5,45 & 19,33 & 11,99 & 66,84 & $<\mathrm{LOQ}$ & $<$ LOQ & $5,07 \uparrow$ & 27,13 & 28,12 & 82,47 & $<\mathrm{LOQ}$ & $<$ LOQ & 8,16 & $<$ LOQ & $14 \uparrow$ \\
\hline $\mathbf{A B} 4 * *$ & $<\mathrm{LOQ}$ & $<\mathrm{LOQ}$ & 5,19 & 76,97 & 10,78 & 21,9 & $<\mathrm{LOQ}$ & $<\mathrm{LOQ}$ & $5,07 \uparrow$ & $236,6 \uparrow$ & 25,02 & 17,61 & 0,81 & $<\mathrm{LOQ}$ & 8,24 & $<\mathrm{LOQ}$ & $14,05 \uparrow$ \\
\hline $\mathbf{A B 5}^{* *}$ & $<\mathrm{LOQ}$ & $<\mathrm{LOQ}$ & 5,5 & 64,52 & 1,4 & 16,27 & $<\mathrm{LOQ}$ & $<\mathrm{LOQ}$ & $5,07 \uparrow$ & $74,63 \uparrow$ & 13,02 & 12,94 & $<\mathrm{LOQ}$ & $<\mathrm{LOQ}$ & 8,22 & $<\mathrm{LOQ}$ & $14,11 \uparrow$ \\
\hline $\mathbf{A B} 6^{* * *}$ & $<\mathrm{LOQ}$ & $<\mathrm{LOQ}$ & 5,55 & 69,14 & $<\mathrm{LOQ}$ & 21,98 & $<$ LOQ & $<\mathrm{LOQ}$ & $5,07 \uparrow$ & $89,93 \uparrow$ & 5,19 & 22,81 & $<\mathrm{LOQ}$ & 8,66 & 8,38 & $<\mathrm{LOQ}$ & $13,83 \uparrow$ \\
\hline $\mathbf{A B} 7 * *$ & $<\mathrm{LOQ}$ & $<\mathrm{LOQ}$ & 5,53 & 68,16 & $<\mathrm{LOQ}$ & 21,07 & $<$ LOQ & $<\mathrm{LOQ}$ & $5,08 \uparrow$ & $74,87 \uparrow$ & 2,91 & 17,73 & $<\mathrm{LOQ}$ & $<\mathrm{LOQ}$ & 8,49 & $<\mathrm{LOQ}$ & $13,69 \uparrow$ \\
\hline AV1** & $<\mathrm{LOQ}$ & $<\mathrm{LOQ}$ & $<\mathrm{LOQ}$ & 22,49 & 28,85 & 0,98 & $<\mathrm{LOQ}$ & $<\mathrm{LOQ}$ & $<\mathrm{LOQ}$ & 59,63 & 8,51 & 15,66 & $<\mathrm{LOQ}$ & $<\mathrm{LOQ}$ & $<\mathrm{LOQ}$ & $<\mathrm{LOQ}$ & $<\mathrm{LOQ}$ \\
\hline AV2** & $<\mathrm{LOQ}$ & $<$ LOQ & $<\mathrm{LOQ}$ & 24,99 & $<\mathrm{LOQ}$ & $<\mathrm{LOQ}$ & $<\mathrm{LOQ}$ & $<\mathrm{LOQ}$ & $<\mathrm{LOQ}$ & 64,82 & 0,97 & 0,57 & $<\mathrm{LOQ}$ & $<\mathrm{LOQ}$ & $<\mathrm{LOQ}$ & $<\mathrm{LOQ}$ & $<\mathrm{LOQ}$ \\
\hline AV3* & $<\mathrm{LOQ}$ & $<\mathrm{LOQ}$ & $<\mathrm{LOQ}$ & 23,24 & $<\mathrm{LOQ}$ & $<\mathrm{LOQ}$ & $<\mathrm{LOQ}$ & $<\mathrm{LOQ}$ & $<\mathrm{LOQ}$ & 75,34 & 4,81 & 0,13 & $<\mathrm{LOQ}$ & $<\mathrm{LOQ}$ & $<\mathrm{LOQ}$ & $<\mathrm{LOQ}$ & $<\mathrm{LOQ}$ \\
\hline $\operatorname{AV4} 4^{* *}$ & $<\mathrm{LOQ}$ & $<\mathrm{LOQ}$ & $<\mathrm{LOQ}$ & 30,28 & $<\mathrm{LOQ}$ & $<\mathrm{LOQ}$ & $<\mathrm{LOQ}$ & $<\mathrm{LOQ}$ & $<\mathrm{LOQ}$ & 44,92 & 13,1 & 12,04 & $<\mathrm{LOQ}$ & $<\mathrm{LOQ}$ & $<\mathrm{LOQ}$ & $<\mathrm{LOQ}$ & $<\mathrm{LOQ}$ \\
\hline AV5** & $<\mathrm{LOQ}$ & $<\mathrm{LOQ}$ & $<\mathrm{LOQ}$ & 38,08 & $<\mathrm{LOQ}$ & $<\mathrm{LOQ}$ & $<$ LOQ & $<\mathrm{LOQ}$ & $<\mathrm{LOQ}$ & 50,64 & 1,73 & $-0,54$ & $<\mathrm{LOQ}$ & $<\mathrm{LOQ}$ & $<\mathrm{LOQ}$ & $<\mathrm{LOQ}$ & $<\mathrm{LOQ}$ \\
\hline AR1** & $<\mathrm{LOQ}$ & $<\mathrm{LOQ}$ & $<\mathrm{LOQ}$ & $<\mathrm{LOQ}$ & 3,35 & $<\mathrm{LOQ}$ & $<\mathrm{LOQ}$ & $<\mathrm{LOQ}$ & $<\mathrm{LOQ}$ & 37,86 & 0,65 & 2,41 & $<\mathrm{LOQ}$ & $<\mathrm{LOQ}$ & $<$ LOQ & $<\mathrm{LOQ}$ & $<\mathrm{LOQ}$ \\
\hline$A R 2 * *$ & $<\mathrm{LOQ}$ & $<\mathrm{LOQ}$ & $<\mathrm{LOQ}$ & 28,27 & $<\mathrm{LOQ}$ & $<\mathrm{LOQ}$ & $<\mathrm{LOQ}$ & $<\mathrm{LOQ}$ & $<\mathrm{LOQ}$ & 47,54 & 7,87 & 10,41 & $<\mathrm{LOQ}$ & $<\mathrm{LOQ}$ & $<\mathrm{LOQ}$ & $<\mathrm{LOQ}$ & $<\mathrm{LOQ}$ \\
\hline $\mathbf{A R 3}^{* * *}$ & $<\mathrm{LOQ}$ & $<\mathrm{LOQ}$ & $<\mathrm{LOQ}$ & 25,45 & $<\mathrm{LOQ}$ & $<\mathrm{LOQ}$ & $<\mathrm{LOQ}$ & $<\mathrm{LOQ}$ & $<\mathrm{LOQ}$ & 47,12 & 11,99 & 11,03 & $<\mathrm{LOQ}$ & $<\mathrm{LOQ}$ & $<\mathrm{LOQ}$ & $<\mathrm{LOQ}$ & $<\mathrm{LOQ}$ \\
\hline
\end{tabular}

AP1-AP9: collection points in the village Pradinho, AB1-AB7- Aldeia Agua Boa, AV1-AV5- Aldeia Verde, AR1-AR3- Aldeia Rafael; Collection: 1st (January / 2015), 2nd (April / 2015) and 3rd (July / 2015). VMP: maximum value allowed, Ordinance 2914/2011, resolution CONAMA: 357/2005 and 396/2008; $\uparrow$ Above VMP., SUP: surface waters, SUB- groundwater, * groundwater points, ** surface water points, (LOQ) limit of quantification. 


\begin{tabular}{|} 
Ambiente \& Água - An Interdisciplinary Journal of Applied Science \\
ISSN 1980-993X - doi:10.4136/1980-993X \\
www.ambi-agua.net \\
E-mail: ambi.agua@gmail.com
\end{tabular}

\title{
Canonical analysis of climatic factors associated with the quality characteristics of drinking water of a city in São Paulo State
}

\author{
ARTICLES doi:10.4136/ambi-agua.2219
}

Received: 01 Dec. 2017; Accepted: 20 Nov. 2018

\author{
Sérgio Augusto Rodrigues ${ }^{*}{ }^{*}$; Paulo André de Oliveira ${ }^{2}$; \\ Ricardo Ghantous Cervi ${ }^{3}{ }^{(D}$; Lilian Cristina Trevizan ${ }^{4}{ }^{(D}$; Carlos Roberto Padovani ${ }^{5}$ \\ ${ }^{1}$ Universidade Estadual Paulista "Júlio de Mesquita Filho" (UNESP), Botucatu, SP, Brasil \\ Faculdade de Ciências Agronômicas (FCA). Departamento de Bioprocessos e Biotecnologia (DBB). \\ E-mail: sergio.rodrigues@unesp.br \\ ${ }^{2}$ Faculdade de Tecnologia de Botucatu (FATEC-BT) \\ Centro Estadual de Educação Tecnológica Paula Souza, Botucatu, SP, Brasil. E-mail: \\ paulo.oliveira108@fatec.sp.gov.br \\ ${ }^{3}$ Universidade Estadual Paulista "Júlio de Mesquita Filho" (UNESP), Itapeva, SP, Brasil \\ Departamento de Engenharia de Produção. E-mail: ricardo.cervi@unesp.br \\ ${ }^{4}$ Companhia de Saneamento Básico do Estado de São Paulo (SABESP), Botucatu, SP, Brasil \\ Divisão De Controle Sanitário Do Médio Tietê (RMOC). E-mail: 1felipe @ sabesp.com.br \\ ${ }^{5}$ Universidade Estadual Paulista "Júlio de Mesquita Filho" (UNESP), Botucatu, SP, Brasil \\ Instituto de Biociências (IBB). Departamento de Bioestatística. E-mail: bioestatistica.ibb@unesp.br \\ "Corresponding author
}

\begin{abstract}
Several factors may contribute to changes in monitoring parameters of drinking water quality, especially climatic characteristics. Behavioral studies of these characteristics are relevant to the rational and sustainable use of water resources and better monitoring of the quality of water available for the population. To assess the association between water quality and climate, this research explored physical-chemical and microbiological characteristics considered important for the monitoring of water quality, analyzed in casual samples collected daily from the distribution system of a city, and considered monthly data of climatic characteristics from 2007 to 2011 . The associations between these two sets of variables were assessed by the multivariate procedure of the canonical correlation analysis. The results indicate a positive correlation between the canonical variable formed by the linear combination of climatic variables and the canonical variable formed by the linear combination of water quality variables.
\end{abstract}

Keywords: canonical correlation, climatic variables, drinking water, multivariate statistics.

\section{Análise canônica de fatores climáticos associados às características de qualidade da água potável de um município do Estado de São Paulo}

\section{RESUMO}

Diversos fatores podem contribuir para alterações dos parâmetros de monitoramento da qualidade da água potável, em especial, as características climáticas. Estudos do comportamento destas características tornam-se relevantes para utilização racional e sustentável dos recursos hídricos e melhor monitoramento da qualidade da água disponibilizada 
à população. Para avaliar a associação entre qualidade da água e o clima, esta pesquisa envolveu características físico-químicas e microbiológicas, consideradas importantes para o monitoramento de sua qualidade, analisadas em amostras casuais coletadas diariamente em pontos da rede de distribuição de um município e dados mensais de características climáticas, no período de 2007 a 2011. As associações entres estes dois conjuntos de variáveis foram avaliadas pelo procedimento multivariado de análise de correlação canônica. Os resultados obtidos indicaram uma correlação positiva entre a variável canônica formada pela combinação linear das variáveis climáticas e a variável canônica formada pela combinação linear das variáveis de qualidade da água.

Palavras-chave: água de consumo, correlação canônica, estatística multivariada, variáveis climáticas.

\section{INTRODUCTION}

Brazil is a privileged country in terms of water resources. Approximately $13 \%$ of the world's freshwater availability is in Brazilian territory. However, this idea of abundance generated a culture of abuse. In addition, the supply of treated water is not uniform among Brazilian regions, presenting several contrasts, such as the percentage of households with treated water (Rodrigues and Batistela, 2013).

Since water is an essential resource for human activities, its inadequate use and degradation due to pollution, coupled with scarcity in some regions, justifies a growing interest in studies related to its quality, and how to use it in a rational and sustainable way.

For Souza et al. (2014), the required level of water quality depends on its use, with different needs for consumption by humans, agriculture, among others.

In the agricultural sector, climatic characteristics and availability of quality water are determinant for productivity, either between food crops or renewable energy production. In urban water supply, where water is a possible source of disease transmission, treatment plants are essential to ensure its potability, preventing contamination and the spread of diseases. For this, the monitoring of water quality must be carried out through periodic assessments of its characteristics throughout the distribution system.

Among the literature, studies assessing the quality of drinking water, physical-chemical and microbiological variables are analyzed before home storage (Freire, 2012; Oliveira et al., 2012). Studies associating water characteristics with cases of diarrhea (Queiroz et al., 2009), water consumption with socioeconomic and climatic variables (Silva et al., 2008b) and water quality with the use and occupation of the soil (Freire and Castro, 2014) are also observed. Assessing variables of surface water quality, climatic and hydrological, Prathumratana et al. (2008) highlight significant correlations between precipitation and several water characteristics.

Studies of climatic variables associated with physical-chemical and microbiological characteristics may contribute to the improvement of techniques for monitoring the quality of water distributed to the population. However, statistically analyzing these variables in an independent way can restrict the interpretation of the analyzed data set. In cases where there is a structure of simultaneous relationship between variables, using multivariate techniques constitutes the most appropriate alternative for exploratory or inferential analysis.

Based on it, the objective of this study was to analyze the simultaneous relationship of climatic variables and physical-chemical and microbiological characteristics of water in the distribution system of a city and to identify the climatic variables that contribute most to the quality of consumed drinking water. 


\section{MATERIAL AND METHODS}

The study used data related to the physical-chemical and microbiological characteristics of water, in addition to climatic variables observed from January 2007 to December 2011 within the urban area of Botucatu city, located in the south-central region of São Paulo State - latitude $-22.88^{\circ}$ and longitude $-48.44^{\circ}$ (Figure 1 ).

Among the monitoring procedures of water quality, residual chlorine (CRL, measured in $\left.m g L^{-1}\right), \mathrm{pH}$, turbidity (TURB, in $u T$ ), apparent color (AC in $U C$ ), fluorine (F, in $m g L^{-1}$ ), water temperature ( $\mathrm{T}$ in $o C$ ), heterotrophic bacteria-forming units (HET in CFU $m L^{-1}$ ) and total coliform occurrence (TCO) are analyzed daily by the company responsible for water collection, treatment and distribution.

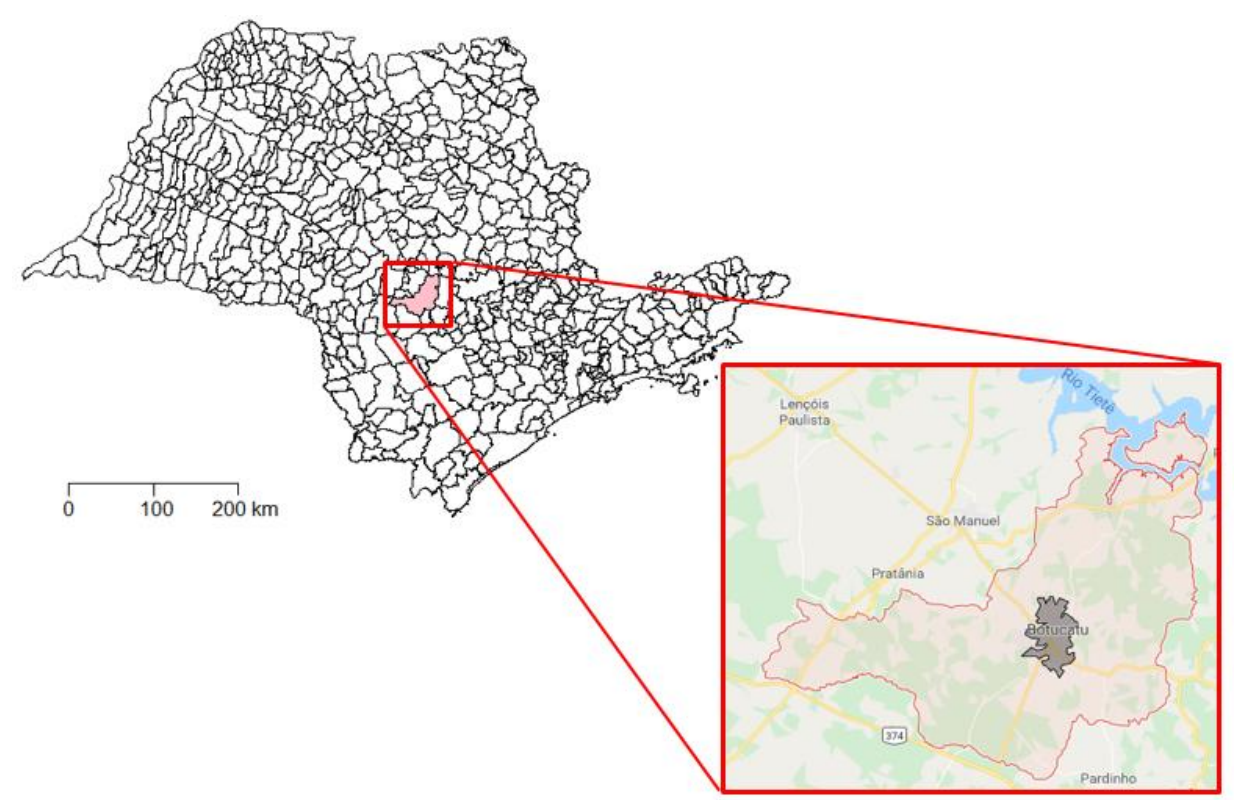

Figure 1. Location of the municipality and urban area of Botucatu, São Paulo State.

This study took into account the water-quality parameters established by Ordinance 518/04 (Brasil, 2011), besides the measurement of water temperature, which cannot be controlled, but should be monitored for possible actions to minimize the risk of bacterial presence (Oliveira et al., 2012).

The quantification of numerical values of the variables was carried out in the sanitary control laboratory of the basic sanitation company, based on casual daily water samples collected at several points within the city distribution system.

The daily data of climatic variables, minimum, maximum and mean monthly temperatures (TMIN, TMAX and TMEAN, all measured in $o C$ ), global solar radiation (RAD, in $\mathrm{cal} \mathrm{cm}^{-2} \mathrm{day}^{-}$ ${ }^{1}$ ), monthly rainfall (MR, in $\mathrm{mm}$ ), number of rainy days in the month (RD), relative air humidity (RH in \%), wind speed (WS, $\mathrm{km} \mathrm{h}^{-1}$ ), insolation (INSOL in hours) and evaporation (EV in $\mathrm{mm}$ ) were obtained from the weather station that provides climatic information to the assessed city.

In order to be compatible with the objective of the study, a database was organized consisting of the monthly averages of two sets of variables (eight variables characterizing water quality in the distribution system, and ten related to climatic characteristics), totaling 60 monthly averages, considered as random and independent sample units. The only exceptions are the total coliform occurrence (TCO) and rainy day (RD) frequency, which represent, respectively, the monthly proportion of samples with the absence of coliforms and the frequency of days with the presence of rain in the given month.

\section{IPABH}

Rev. Ambient. Água vol. 14 n. 1, e2219 - Taubaté 2019 
A statistical procedure of exploratory multivariate analysis was used to describe the associations between the two sets of variables, considering simultaneously all the variables and the entire structure of variation in the data; more precisely, the analysis of canonical correlation (Johnson and Wichern, 2007).

The canonical correlation analysis assesses the degree of association between two sets of random quantitative variables, summarizing the information of each set in linear combinations called canonical variables.

Thus, the random vector, represented by $X^{\prime}$ and composed of 18 variables as described above, is partitioned into two sets of variables: $X^{\prime(1)}$ - representing the random vector with 8 physical-chemical and microbiological variables of water; and $X^{\prime(2)}$ - the vector with 10 climatic variables. Thus, linear combinations of physical-chemical and microbiological variables of water can be obtained by $u t=a^{\prime} t X^{(1)}$ and of climatic variables by $v t=b^{\prime} t X^{(2)}$.

The coefficients $\left(a_{t}^{\prime}\right.$ and $\left.b_{t}^{\prime}\right)$ of $t$ pairs of canonical variables $\left(u_{t}, v_{t}\right)$, for $t$ varying from one to eight (the number of variables of the smallest set), are determined to maximize the correlation among the canonical variables in the set of linear combinations with variances equal to one, presenting all pairs $\left(u_{t}, v_{t}\right)$ and $\left(u_{t^{\prime}}, v_{t^{\prime}}\right)$ uncorrelated to each other, for $t \neq t^{\prime}$. The canonical correlation coefficient $\left(r_{u_{t}, v_{t}}\right)$, consists of the simple linear correlation, in absolute value, among the canonical variables. These correlations are determined in decreasing order of magnitude, i.e., the first pair of canonical variables $\left(u_{1}, v_{1}\right)$ is the one with the highest correlation and so on (Johnson and Wichern, 2007).

To verify if the found canonical correlations were significant, the statistical procedure was used, based on the likelihood ratio test with the correction proposed by Bartlett (Johnson and Wichern, 2007).

Some assumptions are necessary for generalizations of the results of canonical correlation analysis. Although it is not necessary, one of the assumptions for the method to perform better is that the response vector $x_{j}^{\prime}=\left(x_{j}^{\prime(1)} x_{j}^{\prime(2)}\right)$, for $j=1, \ldots n_{i}$, is a random sample of a population with normal multivariate distribution, which was verified by the Multivariate QQ Plot (Johnson and Wichern, 2007).

In order to assist in the interpretation of canonical variables and to improve the information quality of the analysis results, a correlation was established between the canonical variables and the original variables. The correlation between the canonical variables and the original variables of their respective sets, known as canonical charges, are given by $R_{u_{t}, X^{(1)}}=R^{(1,1)} a_{t}$ and $R_{v_{t}, X^{(2)}}=R^{(2,2)} b_{t}$, where $R^{(1,1)}$ and $R^{(2,2)}$ are respectively, the matrices of estimated correlations of the random vectors $X^{\prime}(1)$ and $X^{\prime(2)}$.

The results were discussed at a 5\% level of significance, with the calculations obtained by using R-Gui free software (R CORE TEAM, 2015).

\section{RESULTS AND DISCUSSION}

Initially, a descriptive statistical analysis of the climatic data was performed, showing that the period with the highest rainfall is concentrated between October and January. December and January had the most intense rainfall, with an average of $416.9 \mathrm{~mm}$ in January. On the other hand, the rains are very scarce between May and September, observing an average of five days with rain per month. August presented an average of $43.6 \mathrm{~mm}$ of precipitation. In addition, the city presented mild mean temperatures during all months of the year, with a minimum of $17.75^{\circ} \mathrm{C}$ in June, and a maximum of $23.60^{\circ} \mathrm{C}$ in February. It was also observed that the less rainy period corresponds to the colder months. 
Considering the water quality variables, few changes are noticed in the monthly mean of these variables in the city distribution system, indicating standard parameters of equivalent water quality throughout the months and meeting the drinking water analysis standards established by American Public Health Association (APHA et al., 2005).

Oliveira et al. (2012) also analyzed data on physical-chemical and microbiological variables, considering tap water samples before household storage, making sure that all parameters of water quality analyzed in the distribution system were within the standards established by the legislation. Freire (2012) analyzed samples from the treatment plant, the distribution system and the exit of the reservoirs, in order to assess the physical-chemical and microbiological variables of water distributed in Recife, Pernambuco state, verifying that household storage is a deteriorating factor of water quality.

Pinto and Maheshwari (2011) point out that some countries have been seeking to develop more efficient methodologies to evaluate water quality for human consumption and biotic species. They reported that the techniques of multivariate statistics are drawing attention, since they facilitate the understanding of the biological phenomenon, which, usually, involves datasets with many variables correlated with each other.

Regarding the study of joint association between the two sets of variables, at first by visual inspection of the multivariate probability QQ Plot ("Chi-Square plot"), with the exception of the two largest ordered distances, a trend of the others in aligning themselves around the bisector is noticed, suggesting, in practice, data adherence to the multivariate normal distribution of probability. In addition, the exploratory analysis indicated that the data of water characteristics are approximately symmetrical, an important condition for the robustness of the test in relation to non-normality (Mardia, 1974).

The canonical correlation coefficients, with their respective significance tests, are presented in Table 1. It can be seen that two, the first ones, out of eight canonical correlations found were significant $(\mathrm{p}<0.05)$, presenting values equal to 0.920 and 0.810 respectively. These results show evidence of an association between climatic characteristics and water quality.

Assessing the association between groundwater quality and land use in a city of Espírito Santo state, Menezes et al. (2014) identified a significant linear association between land use in the region and water quality through an exploratory study using canonical correlation.

Also in Table 1, it is possible to observe the coefficients of the canonical functions of each pair of variables and to identify that the canonical variable $u_{1}$ is associated with the water quality variables, in a contrast between the sum of apparent color (AC), fluoride (F) and water temperature (T) variables and the sum of turbidity (TURB), free residual chlorine (CRL), $\mathrm{pH}$, heterotrophic bacteria (HET) and total coliforms (TCO). The weights of each variable in this association are expressed in the coefficients of the canonical function, being the variables for $\mathrm{T}$ (0.641), CRL (-0.630), TURB (-0.514) and AC (0.433) with higher absolute weights. In the same way, the most expressive coefficients can be observed in the composition of the canonical function $v_{1}$.

Figure 2 shows the scatter diagrams of the standard values of the first (Figure 2A) and second (Figure 2B) pair of canonical variables.

Figure $2 \mathrm{~A}$ shows a positive linear association between the canonical variable $v_{1}$ (climatic component) and the variable $u_{1}$ (water quality component). In this sense, it can be said that the canonical variable $u_{1}$ presents high values associated with high values of the variable $v_{1}$, mainly in the months of June and July (winter), whereas low values for the two variables are observed between the months of November to March (hottest months of the year).

Figure 3 highlights the canonical charges of the first (Figure 3A and 3C) and second (Figure 3B and 3D) pair of canonical variables. The greater the absolute value of the canonical charge, indicated in the chart by the longer bar, the more important is the original variable to represent its respective canonical variable, that is, the greater the association of this variable

\section{IPABH}

Rev. Ambient. Água vol. 14 n. 1, e2219 - Taubaté 2019 
with the respective canonical variable (Johnson and Wichern, 2007).

Table 1. Coefficients of canonical functions, canonical correlation between water quality component $\left(u_{t}\right)$ and climatic $\left(v_{t}\right)$, eigenvalue, and result of the statistical test.

\begin{tabular}{|c|c|c|c|c|c|c|c|c|c|}
\hline \multirow[b]{2}{*}{$\begin{array}{l}\text { Canonical } \\
\text { Variables }\end{array}$} & \multirow[b]{2}{*}{$\begin{array}{c}\text { Original } \\
\text { variables }\end{array}$} & \multicolumn{8}{|c|}{ Coefficients of canonical functions } \\
\hline & & $\begin{array}{c}1^{\mathrm{st}} \\
\left(u_{1} \cdot v_{1}\right)\end{array}$ & $\begin{array}{c}2^{\text {nd }} \\
\left(u_{2} \cdot v_{2}\right)\end{array}$ & $\begin{array}{c}3^{\text {rd }} \\
\left(u_{3} \cdot v_{3}\right)\end{array}$ & $\begin{array}{c}4^{\text {th }} \\
\left(u_{4} \cdot v_{4}\right)\end{array}$ & $\begin{array}{c}5^{\text {th }} \\
\left(u_{5} \cdot v_{5}\right)\end{array}$ & $\begin{array}{c}6^{\text {th }} \\
\left(u_{6} \cdot v_{6}\right)\end{array}$ & $\begin{array}{c}7^{\text {th }} \\
\left(u_{7} \cdot v_{7}\right)\end{array}$ & $\begin{array}{c}8^{\text {th }} \\
\left(u_{8} \cdot v_{8}\right)\end{array}$ \\
\hline \multirow{8}{*}{$\begin{array}{l}\text { water } \\
\text { quality } u_{t}\end{array}$} & TURB & 0.514 & -0.938 & 0.096 & -0.339 & 0.036 & -1.409 & -1.105 & 1.561 \\
\hline & $\mathrm{AC}$ & -0.433 & 0.602 & -0.366 & 0.165 & 0.242 & 0.607 & 0.834 & -2.068 \\
\hline & $\mathrm{F}$ & -0.038 & 0.268 & -0.015 & 0.909 & 0.002 & -0.680 & 0.766 & 0.276 \\
\hline & CRL & 0.630 & -0.342 & -0.231 & 0.959 & -1.013 & -0.519 & 0.790 & -0.173 \\
\hline & $\mathrm{pH}$ & 0.219 & 0.184 & 0.206 & -0.339 & -1.052 & 0.049 & 0.916 & -0.242 \\
\hline & $\mathrm{T}$ & -0.641 & -0.534 & -0.089 & 0.432 & -0.661 & -0.220 & -0.268 & 0.006 \\
\hline & HET & 0.137 & -0.578 & 0.430 & -0.161 & 0.686 & 0.288 & 0.335 & -0.026 \\
\hline & TCO & 0.041 & 0.140 & 0.846 & 0.127 & 0.007 & 0.038 & -0.487 & -0.314 \\
\hline \multirow{10}{*}{$\operatorname{climatic} v_{t}$} & $\mathrm{RD}$ & -0.242 & -0.148 & -1.523 & -0.678 & 0.097 & 0.701 & 0.320 & -0.859 \\
\hline & TMIN & -0.657 & -0.215 & 0.902 & -0.152 & -1.413 & 1.332 & -0.196 & -0.476 \\
\hline & TMAX & -0.241 & 0.246 & 0.595 & 0.280 & 0.323 & -0.205 & -1.876 & -0.404 \\
\hline & TMEAN & -0.030 & -0.420 & -0.587 & 0.085 & 0.418 & -1.595 & 1.400 & -0.069 \\
\hline & MR & 0.425 & -0.273 & 0.683 & 0.102 & 0.318 & -0.205 & -0.369 & 1.051 \\
\hline & RH & -0.301 & 0.800 & 0.182 & -0.241 & -0.289 & -0.247 & -0.383 & 0.528 \\
\hline & WS & -0.230 & 0.603 & 0.105 & 0.210 & 0.282 & 0.238 & -0.092 & -0.430 \\
\hline & EV & 0.433 & 0.384 & -1.452 & 0.329 & -0.433 & -0.190 & 0.221 & 1.027 \\
\hline & INSOL & 0.228 & -0.124 & -0.305 & -0.160 & -0.985 & 0.496 & -0.027 & -0.228 \\
\hline & RAD & -0.368 & -0.512 & 0.819 & 0.300 & 0.785 & 0.456 & 0.491 & 0.231 \\
\hline \multicolumn{2}{|c|}{$\begin{array}{l}\text { Canonical Correlation } \\
\left(r_{u_{t}} \cdot v_{t}\right)\end{array}$} & 0.920 & 0.810 & 0.604 & 0.524 & 0.477 & 0.360 & 0.302 & 0.092 \\
\hline \multirow{3}{*}{\multicolumn{2}{|c|}{$\begin{array}{l}\text { Eigenvalue } \\
\text { Test Statistics } \\
\text { df }\end{array}$}} & 0.847 & 0.656 & 0.364 & 0.275 & 0.227 & 0.130 & 0.090 & 0.009 \\
\hline & & 208.66 & 118.22 & 65.64 & 43.11 & 26.79 & 13.24 & 5.76 & 0.48 \\
\hline & & 80 & 63 & 48 & 35 & 24 & 15 & 8 & 3 \\
\hline \multicolumn{2}{|l|}{$\mathrm{p}$ value } & $<0.001$ & $<0.001$ & 0.05 & 0.160 & 0.310 & 0.580 & 0.670 & 0.920 \\
\hline
\end{tabular}

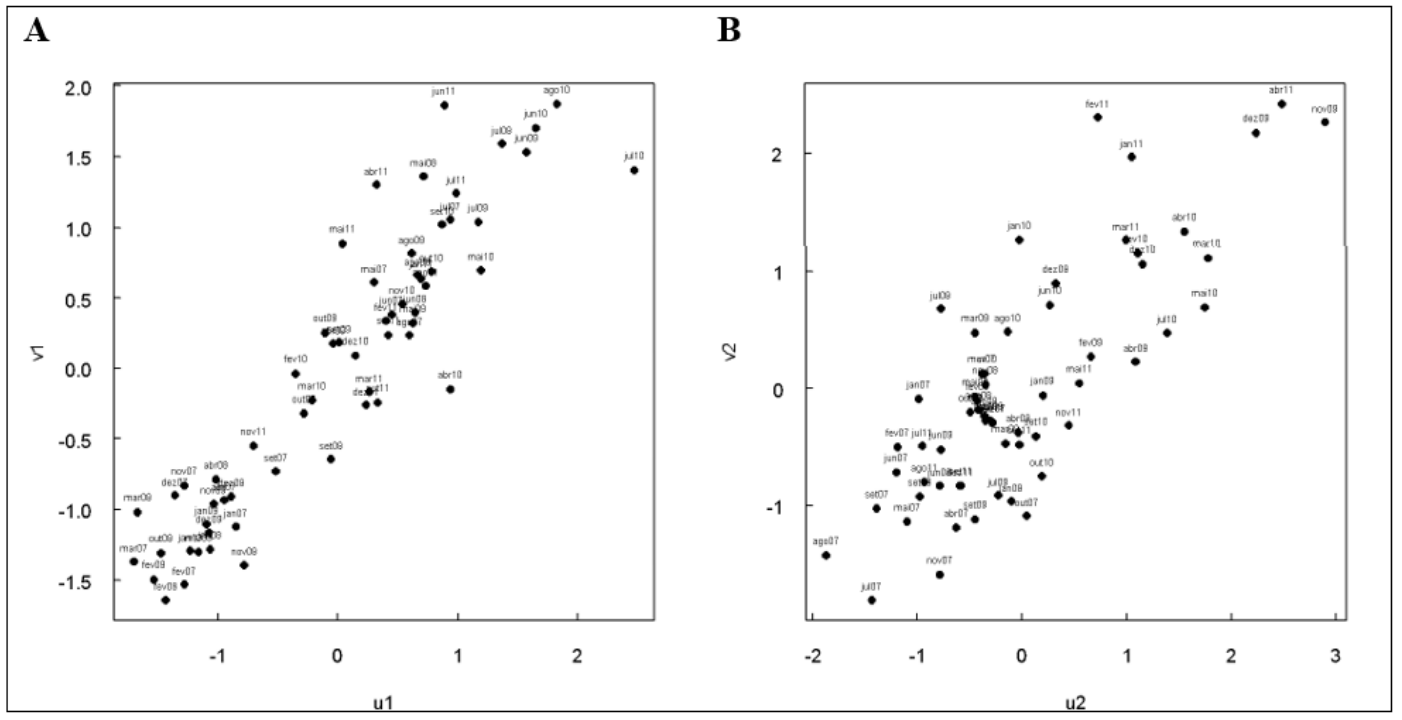

Figure 2. Scatter plot of the two pairs of standardized canonical variables.

Analyzing the canonical charges for the interpretation of $u_{1}$ (Figure $3 \mathrm{~A}$ ), the water quality variables that present higher charges (higher association with $u_{1}$ ) are water temperature $(-0.82)$ 
and chlorine (0.72), followed by fluorine (-0.47). The other variables presented low expressive canonical charges (below 0.4). It can be seen that higher concentrations of chlorine occur with lower water temperatures and concentrations of fluorine. This pattern suggests an interpretation for $u_{1}$ related to "water treatment chemicals".

Thus, it can be said that water temperature and free residual chlorine presented the highest percentages of variance explained by the first canonical variable of water quality $\left(u_{1}\right)$, i.e., $67 \%$ $\left(0,82^{2} \times 100\right)$ and $52.1 \%\left(0,72^{2} \times 100\right)$, respectively.

When observing the canonical charges of the climatic variables set (Figure 3C), the variables that have the highest correlations with $v_{1}$ are the minimum $(-0.82)$, mean $(-0.72)$, and maximum temperature $(-0.56)$, number of rainy days $(-0.57)$, and relative humidity $(-0.53)$. This pattern suggests $v_{1}$ interpreted as "moisture and temperature characteristics".

Thus, the first canonical variable of climatic characteristics $\left(v_{1}\right)$ explains $67 \%$ of the variability of the minimum temperature variable, $52 \%$ of the mean temperature and around $30 \%$ of the variability of rainy days, maximum temperature, and relative air humidity variables (canonical charges squared).

Therefore, based on the analysis of the canonical charges and the result presented in Figure $2 \mathrm{~A}$, we can say that June and July present high values for the two canonical variables, indicating a drier period and lower temperatures associated with a period in which the water distributed to the population had lower temperatures, less fluorine, and more chlorine. However, the months from November to March were shown to be a wetter period, with a higher number of rainy days and higher temperatures associated with months when water presented less chlorine, higher temperatures, and higher fluoride concentration (Figure 3).

A

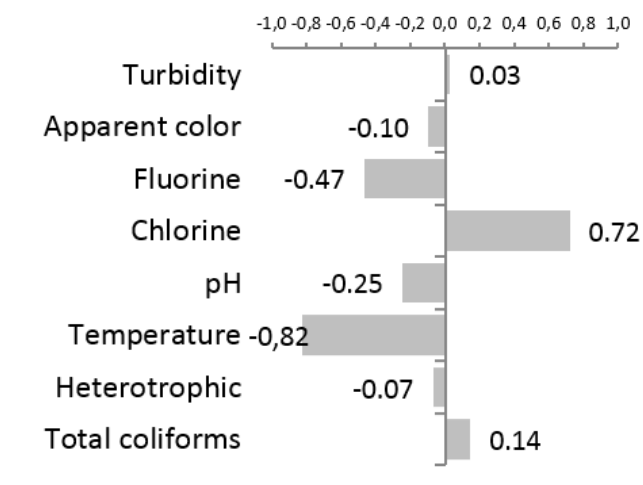

C

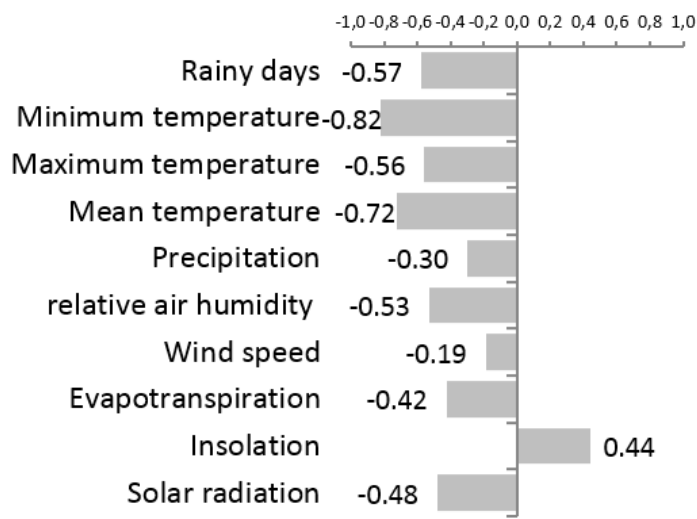

B

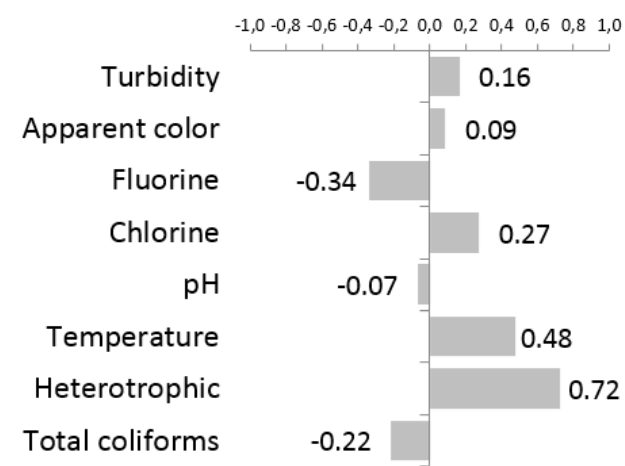

D

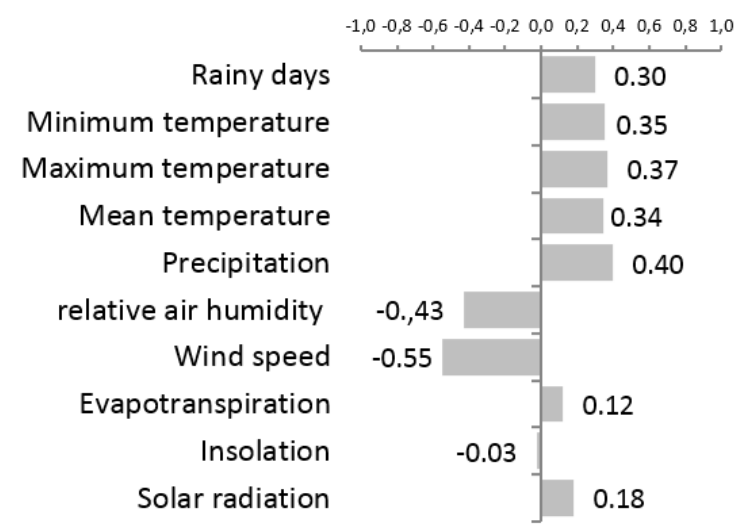

Figure 3. Canonical charges of the components: $u_{1}(\mathrm{~A}), u_{2}(\mathrm{~B}), v_{1}(\mathrm{C})$ and $v_{2}(\mathrm{D})$.

Nouri et al. (2015) observed significant differences in temperature, turbidity and chlorine concentration among water samples collected in the distribution system of a city in Iran in two seasons of the year (winter and spring), while $\mathrm{pH}$ was not different. It was also observed that

\section{IPABH}

Rev. Ambient. Água vol. 14 n. 1, e2219 - Taubaté 2019 
the water temperature showed a significant negative correlation only with free residual chlorine, a result similar to that observed in the water quality component of this study, evidencing the importance of this parameter of chlorine decay studies in drinking water distribution systems.

Assessing the interrelationships among precipitation, raw water quality and treatment, Santos and Sampaio (2009) verified that the precipitation was negatively associated with $\mathrm{pH}$ and turbidity, and positively with apparent color. They also observed that changes in water quality led to an increase in chlorine dosages at the water treatment plant during the wettest period.

In the process of water disinfection with chlorine, normally used in water treatment plants, it is possible to observe the formation of Trihalomethanes (THM), a carcinogenic chemical compound, and its formation is associated with several aspects, i.e., with the presence of organic material, with the treatment operating processes, and with geographic and climatic factors. A study carried out in a water distribution system in Scotland indicated significant positive correlations between THM concentration with dissolved organic carbon (DOC) and with the ambient temperature, while the chlorine concentration (free and total) was associated negatively with THM. Thus, in situations of higher ambient temperature, THM monitoring becomes essential, highlighting the importance of studies on the impact of global warming on water quality (Valdivia-Garcia et al., 2016).

Considering the second canonical pair (Figure 2B), some particularities of answers are highlighted in certain months and years. It was possible to verify that the months of November (2009), December (2009) and April (2011) presented high values in the two canonical variables, $u_{2}$ and $v_{2}$. In contrast, low values were found in July and August (2007). In January and February (2011), there were low values for the water quality component associated with high values of the climatic component.

Based on the canonical charges of this pair, it was observed that the canonical variable $u_{2}$ (representing another water characteristic), assumes higher values in the months in which water has less fluoride, higher chlorine concentration, higher temperatures and higher amount of heterotrophic bacteria (Figure 3B); while $v_{2}$ is higher in the months with higher precipitation, higher minimum, maximum and mean temperatures, low relative air humidity and low wind speed (Figure 3D).

Similarly, Freire and Castro (2014) used the canonical correlation technique to summarize the water quality in a component related to the concentration of nitrates and dissolved oxygen, verifying that a greater degradation of water quality in the watershed of Itapemirim River, Espírito Santo state, is associated with the use and occupation of the soil; more precisely, with the places with greater human activity. Bishankha et al. (2013) observed that bacterial growth in water treatment plants is strongly positively correlated with water temperature, evidencing the importance of monitoring free residual chlorine in times with higher temperatures.

Analyzing the differences between the dry period (June, July, August and October) and rainy period (December, January, February and April), concerning the behavior of the physicalchemical and biological variables analyzed in water samples from a dam that supplies tanks and nurseries for fish farming, Bufon and Landim (2007) verified that the values of phosphates and total phosphorus are directly related to the material suspended in water only during the dry period.

Regarding the influence of rainfall on the characteristics of raw water quality (Purus River, Amazonas state), Silva et al. (2008a) observed a negative correlation between precipitation and turbidity, and positive correlation between precipitation and temperature, conductivity, dissolved oxygen, total suspended solids, and $\mathrm{pH}$.

Thus, in general, the discussed results indicate that it is possible to summarize the information of variables related to water quality in the city distribution system and climatic

Rev. Ambient. Água vol. 14 n. 1, e2219 - Taubaté 2019 
variables in two pairs of components or canonical variables with significant correlations $\left(u_{1}\right.$, $\left.v_{1}\right)$ and $\left(u_{2}, v_{2}\right)$, each expressing a particular water quality and climatic characteristic.

As for this study limitation, the fact stands out that these results are restricted to the city described here, with the possibility of repetition in other localities, provided that a consistent data set is available.

\section{CONCLUSION}

The study pointed to the existence of two significant positive correlations between the set of water quality variables in the distribution system and the set of climatic variables.

In the context of the canonical charges, the water quality component is highlighted for fluorine, chlorine, and temperature; and for the climatic component, the frequency of rainy days, temperatures, relative air humidity, solar radiation and insolation. The months with high humidity, higher temperatures, higher levels of solar radiation and lower insolations are associated with months in which the water in the system presents with higher temperatures, higher concentrations of fluorine and lower concentrations of chlorine.

It is also observed that the months in which water presented with less fluorine, higher chlorine concentration, higher temperatures and higher amount of heterotrophic bacteria also presented with a higher precipitation, higher temperatures, lower relative air humidity and low wind speed.

In the warmer months and in months with higher precipitation, there is a need to increase the amount of chlorine in the water, as it is lost by evaporation at higher temperatures, becoming more susceptible to contamination by heterotrophic bacteria.

These conclusions confirm the current procedure of increasing chlorine in summer and emphasize the need for changes in chlorine concentrations according to ambient temperature and precipitation levels. Thus, the presented procedure can be used as a technique to assess the association of water characteristics with climatic factors in the various cities and sanitation companies.

\section{REFERENCES}

AMERICAN PUBLIC HEALTH ASSOCIATION (APHA); AMERICAN WATER WORKS ASSOCIATION (AWWA); WATER ENVIRONMENT FEDERATION (WEF). Standard methods: for the examination of water and wastewater. 21st. ed. Washington, DC, 2005.

BISHANKHA, S.; BHATTA, D. R.; JOSHI, D. R.; JOSHI, T. P. Assessment of microbial quality of chlorinated drinking tap water and susceptibility of gram negative bacterial isolates towards chlorine, Journal of Science, Engineering and Technology, v. 9, n. 1, p. 222-229, 2013. http://dx.doi.org/10.3126/njst.v13i1.7456

BRASIL. Ministério da Saúde. Portaria n 2.914, 14 de dezembro de 2011. Procedimentos de controle e de vigilância da qualidade da água para consumo humano e seu padrão de potabilidade. Diário Oficial [da] União, seção 1, Brasília, DF, n. 239, p. 39, 14 dez. 2011.

BUFON, A. G. M.; LANDIM, P. M. B. Análise da qualidade da água por metodologia estatística multivariada na Represa Velha (CEPTA/IBAMA/PIRASSUNUNGA/SP). Holos Environment, v. 7, n. 1, p. 42-59, 2007. http://dx.doi.org/10.14295/holos.v7i1.972

FREIRE, R. C. Qualidade da água nos reservatórios domiciliares na região metropolitana da cidade do Recife-PE. Journal of Management \& Primary Health Care, v. 3, n. 2, p. 102-105, 2012. 
FREIRE, A. P.; CASTRO, E. C. Análise da Correlação do uso e Ocupação do Solo e da Qualidade da Água, RBRH-Revista Brasileira de Recursos Hídricos, v. 19, n. 1, p. 41 49, 2014. http://dx.doi.org/10.21168/rbrh.v19n1.p41-49

JOHNSON, R. A.; WICHERN, D. W. Applied multivariate statistical analysis. 6. ed. New Jersey: Prentice-Hall, 2007. 800 p.

MARDIA, K. V. Assessment of multinormality and the robustness of Hotelling T2 test. Applied Statistics, v. 24, p. 163-171, 1974.

MENEZES, J. P. C.; BERTOSSI, A. P. A.; SANTOS, A. R.; NEVES, M. A. Correlação entre uso da terra e qualidade da água subterrânea. Engenharia Sanitária e Ambiental, v. 19, n. 2, p. 173-186, 2014. https://doi.org/10.1590/S1413-41522014000200008

NOURI, A.; SHAHMORADI, B.; DEHESTANI-ATHAR, S.; MALEKI, A. Effect of temperature on $\mathrm{pH}$, turbidity and residual free chlorine in Sanandaj water distribution network, Iran. Journal of advances in environmental health research, v. 3, n. 3, 2015. https://doi.org/10.22103/JAEHR.2015.40202

OLIVEIRA, A. S.; SANTOS, D. C.; OlIVEIRA, E. N. A.; BRITO, J. G.; SILVA, W. L. Qualidade da água para consumo humano distribuída pelo sistema de abastecimento público em Guarabira - PB. Revista Verde de Agroecologia e Desenvolvimento Sustentável, v. 7, n. 2, p. 199-205, 2012.

PINTO, U.; MAHESHWARI, B. L. River health assessment in peri-urban landscapes: na application of multivariate analysis to identify the key variables. Water Research, v. 45, p. 3915-3924, 2011. https://doi.org/10.1016/j.watres.2011.04.044

PRATHUMRATANA, L.; STHIANNOPKAO, S.; KIN K. W. The relationship of climatic and hydrological parameters to surface water quality in the lower Mekong River. Environment International, v. 34, p. 860-866, 2008. https://doi.org/10.1016/j.envint.2007.10.011

QUEIROZ, J. T. M.; HELLER, L.; SILVA, S. R. Análise da correlação de ocorrência de doença diarreia aguda com a qualidade da água para consumo humano no município de VitóriaES. Saúde Sociedade, v. 18, n. 3, p. 479-489, 2009. http://dx.doi.org/10.1590/S010412902009000300012

R CORE TEAM. R: A language and environment for statistical computing. Vienna: $R$ Foundation for Statistical Computing, 2015. Disponível em: http://cran.r-project.org/. Acesso em: 20 jan. 2015.

RODRIGUES, S. A.; BATISTELA, G. C. Uma revisão sobre a disponibilidade hídrica brasileira para geração de energia elétrica, Geoambiente on-line, n. 21, p. 48-67, 2013. https://doi.org/10.5216/revgeoamb.v0i21.27907

SANTOS, G. O.; SAMPAIO, G. M. S. Interrelações entre as chuvas, a qualidade da água bruta e o tratamento da água: Estudo de caso. Revista Tecnol, v. 30, n. 2, p. 163-174, 2009.

SILVA, A. E. P.; ANCELIS, C. F.; MACHADO, L. A. T.; WAICHAMAN, A. V. Influência da precipitação na qualidade da água do rio Purus. Acta Amazônica, v. 38, n. 4, p. 733742, 2008a. http://dx.doi.org/10.1590/S0044-59672008000400017

SILVA, W. T. P.; SILVA, L. M.; CHICHORRO, J. F. Gestão de recursos hídricos: perspectivas do consumo per capita de água em Cuiabá. Engenharia Sanitária e Ambiental, v. 13, n. 1, 2008b. http://dx.doi.org/10.1590/S1413-41522008000100002 
SOUZA, J. R.; MORAES, M. E. B.; SONODA, S. L.; SANTOS, H. C. R. G. A importância da qualidade da água e os seus múltiplos usos: caso do Rio Almada, sul da Bahia, Brasil. Revista eletrônica do Prodema, v. 8, n. 1, p. 26-45, 2014.

VALDIVIA-GARCIA, M.; WEIR, P.; FROGBROOK, Z.; GRAHAM, D. W.; WERNER, D. Climatic, geographic and operational determinants of trihalomethanes (THMs) in drinking water systems, Scientific Reports - Nature, v. 6, p. 35027, 2016. https://doi.org/10.1038/srep35027 


\begin{tabular}{|} 
Ambiente \& Água - An Interdisciplinary Journal of Applied Science \\
ISSN 1980-993X - doi:10.4136/1980-993X \\
www.ambi-agua.net \\
E-mail: ambi.agua@gmail.com
\end{tabular}

\title{
Potentially toxic metals in lotic systems with aptitude for aquaculture at the watershed Mantaro River, Peru
}

\author{
ARTICLES doi:10.4136/ambi-agua.2261
}

Received: 27 Mar. 2018; Accepted: 16 Nov. 2018

\author{
María Custodio $^{1 *(D)}$; Fernán Cosme Chanamé Zapata1 ${ }^{1 D}$; \\ Danny Julio Cruz Flores ${ }^{1}{ }^{1}$; Wilfredo Bulege Gutiérrez ${ }^{2}$; \\ ${ }^{1}$ Universidad Nacional del Centro del Peru (UNCP), Huancayo, Junín, Peru \\ Department of Zootecnia. E-mail: mcustodio@uncp.edu.pe, \\ fernan_chz@hotmail.com, cruzfloresdj@gmail.com \\ ${ }^{2}$ Universidad Continental, Huancayo, Junín, Peru \\ Direction of Research. E-mail: wbulege@continental.edu.pe \\ *Corresponding author
}

\begin{abstract}
The objective of the study was to analyze the concentration of $\mathrm{Cu}, \mathrm{Zn}, \mathrm{Fe}, \mathrm{Pb}$ and $\mathrm{As}$ in river water suitable for aquaculture in the watershed of the Mantaro River using multivariate statistical methods, during the period 2011-2013. The determinations of total heavy metals in water collected during two different climatic periods were performed by atomic absorption spectrophotometry, according to the methodology recommended by FAO. The results obtained show that, in the seven rivers evaluated, the average concentration of $\mathrm{Pb}, \mathrm{Fe}$ and $\mathrm{Cu}$ exceeded the quality standards of Peru's continental water for the extraction and cultivation of hydrobiological species and USEPA standards for the protection of fish and aquatic life. The average concentration of $\mathrm{Zn}$ only exceeded USEPA standards. While the concentrations of $\mathrm{Pb}$ and $\mathrm{Cu}$ also surpassed those of the WHO. The cluster analysis suggests that the evaluated rivers, in which fish farming activity is intensively developed, have similar characteristics in relation to the concentration of heavy metals. According to the analysis of main components, in Component 1 , there are moderate loads for arsenic; in Component 2, there is a strong load for zinc and relatively low loads for iron; and, in Component 3, there is a moderate load for iron. The discriminant analysis revealed that two of the five variables were significant predictors of the season; in this case, copper and lead were sufficient to discriminate the variables between the rainy or dry season.
\end{abstract}

Keywords: fit fitness, heavy metals, lotic system.

\section{Metais potencialmente tóxicos em sistemas lóticos com aptidão para a aquicultura na bacia hidrográfica do rio Mantaro, Peru}

\section{RESUMO}

O objetivo do estudo foi analisar as concentrações de $\mathrm{Cu}, \mathrm{Zn}, \mathrm{Fe}, \mathrm{Pb}$ e As em rios de águas com aptidão para a aquicultura na bacia do rio Mantaro utilizando métodos estatísticos multivariados, no período 2011-2013. A determinação do total de metais pesados em água coletada durante dois períodos climáticos contrastantes foi realizada por espectrofotometria de absorção atômica, de acordo com a metodologia recomendada pela FAO. Os resultados obtidos 
mostram que nos sete rios avaliados a concentração média de $\mathrm{Pb}, \mathrm{Fe}$ e $\mathrm{Cu}$ excedeu os padrões de qualidade da água continental do Peru para extração e cultivo de espécies hidrobiológicas e padrões USEPA para a proteção de peixes e vida aquática. A concentração média de Zn excedeu apenas os padrões da USEPA. Enquanto as concentrações de $\mathrm{Pb}$ e Cu também superaram as da OMS. A análise de agrupamento sugere que os rios avaliados, nos quais a atividade pesqueira é intensamente desenvolvida, têm características semelhantes em relação à concentração de metais pesados. De acordo com a análise dos componentes principais, no componente 1, há cargas moderadas para o arsênio; no componente 2, há uma carga forte para o zinco e cargas relativamente baixas para o ferro e, no componente 3 , é uma carga moderada de ferro. A análise discriminante revelou que duas das cinco variáveis foram preditores significativos do tempo, neste caso, cobre e chumbo foram suficientes para discriminar as variáveis entre a estação chuvosa ou a estação seca.

Palavras-chave: fitness de peixes, metais pesados, sistemas lóticos.

\section{INTRODUCTION}

In the last decades, the balance of aquatic ecosystems has been altered by the increase in discharges of wastewater containing organic and inorganic pollutants, highlighting heavy metals among the latter, which, unlike organic pollutants that can be metabolized by aquatic microbiota, are indestructible (Gunatilake, 2015). The contamination generated by these metals due to increasing industrialization represents a special environmental risk due to its persistence in the environment, possible bioaccumulation and biomagnification in the food chain (Kwok et al., 2014).

Some heavy metals, such as copper $(\mathrm{Cu})$, zinc $(\mathrm{Zn})$, cobalt $(\mathrm{Co})$ and iron $(\mathrm{Fe})$, are necessary for life and are only considered a hazard when they exceed the established concentrations (Waseem et al., 2014). Others such as cadmium $(\mathrm{Cd})$, mercury $(\mathrm{Hg})$ and lead $(\mathrm{Pb})$ were discharged into the rivers by various factories and cause undesirable changes in the quality of the environment of these ecosystems, affecting the ecological balance of the aquatic environment and ultimately human beings through the food chain (Chanamé et al., 2017).

Among the aquatic species that are exposed to heavy metals, fish are most commonly affected by these toxic pollutants that exert their action in different organs. Studies conducted to examine the concentration of heavy metals in water and in different fish species at different latitudes have revealed that both essential and non-essential metals can cause biotoxic effects (Kwok et al., 2014). In other studies, the evaluation of heavy metals in different compartments has been complemented with the determination of water quality through water quality indexes and geo-accumulation to indicate the level of contamination by heavy metals presented by sediment samples in the sea and suspension. However, the degree of contamination in the environments and in fish tissues depends on the type of contaminant, the fish species, the sampling site, the trophic level and their mode of feeding (Islam et al., 2015; Kapia et al., 2016).

The vast ocean of the Mantaro River is one of the areas of Peru with great metallurgical, mining and fish-farming activity. Nine decades ago the metallurgical industry began its operation in the circuits $\mathrm{Cu}, \mathrm{Pb}, \mathrm{Zn}, \mathrm{Ag}, \mathrm{Au}, \mathrm{Cd}, \mathrm{In}, \mathrm{Bi}, \mathrm{Sb}, \mathrm{As}, \mathrm{Se}$ and Te. There are also byproducts of these activities, such as sulfuric acid, sodium bisulfate, copper, sulphate, zinc powder, arsenic trioxide and a variety of residues with a high level of toxicity, generating air pollution in La Oroya, one of the most polluted cities in the world, and in contiguous rural areas. This situation has led to backlash against the environmental pollution generated by this industry, leading to the suspension of its operation in 2009. On the other hand, the mining industry through its wastewater discharges is also exerting strong pressure on the water quality and aquatic biodiversity of the hydrographic units that form at the bottom of the Mantaro River, 
therefore reducing the multiple uses of the water. However, in the last decade, many of the lotic systems of this watershed have intensified production of rainbow trout for export purposes.

In this regard, and given the limited information available on the concentration of heavy metals in lotic systems with fish fitness in the bottom of the Mantaro River and the risks that accumulation can represent for the aquatic environment and human health, it is necessary to have information that reveals the level of contamination that these aquatic systems present. The objective of the study was to analyze the concentration of $\mathrm{Cu}, \mathrm{Zn}, \mathrm{Fe}, \mathrm{Pb}$ and $\mathrm{As}$ in rivers water with aptitude for aquaculture in the Mantaro River Basin using multivariate statistical methods, during the period 2011-2013.

\section{METHODS AND RESOURCES}

\subsection{Area of the Study}

The Mantaro River is located in the Central Andes of Peru, between the latitudes of: $10^{\circ} 34^{\prime \prime} \mathrm{S}-13^{\circ} 35^{\prime \prime} \mathrm{S}$ and longitudes: $73^{\circ} 55^{\prime \prime} \mathrm{W}-76^{\circ} 40^{\prime \prime} \mathrm{W}$, with altitudes ranging from 500 masl to 5,350 masl. It covers an area of approximately $34,550 \mathrm{~km}^{2}$, whose flow depends on rainfall, the water level of Lake Junin and the lagoons located at the foot of the mountains in the western and Eastern mountain ranges (Zubieta et al., 2017).

In the Junin region, the tributaries of the Mantaro River with aptitude for aquaculture considered in the study are located in the districts of Paccha and La Oroya of the Yauli Province (Figure 1). In Paccha, the Casaracra and Quinuacocha Rivers are located at 3801 masl $(396041 \mathrm{E}, 8733599 \mathrm{~N})$ and 3670 masl $(399331 \mathrm{E}, 8728673 \mathrm{~N})$, respectively. In La Oroya, Pacchapata Rivers at 4200 masl (401917E, 8726727N), Geshgash at 3900 masl (407442E, 8720525 N), Papahuay at 3920 masl (409690E, 8715795N), Capaco at 3900 masl (412113E, 8714136N) and Paraíso at 3850 masl (409735E, 8713106N).

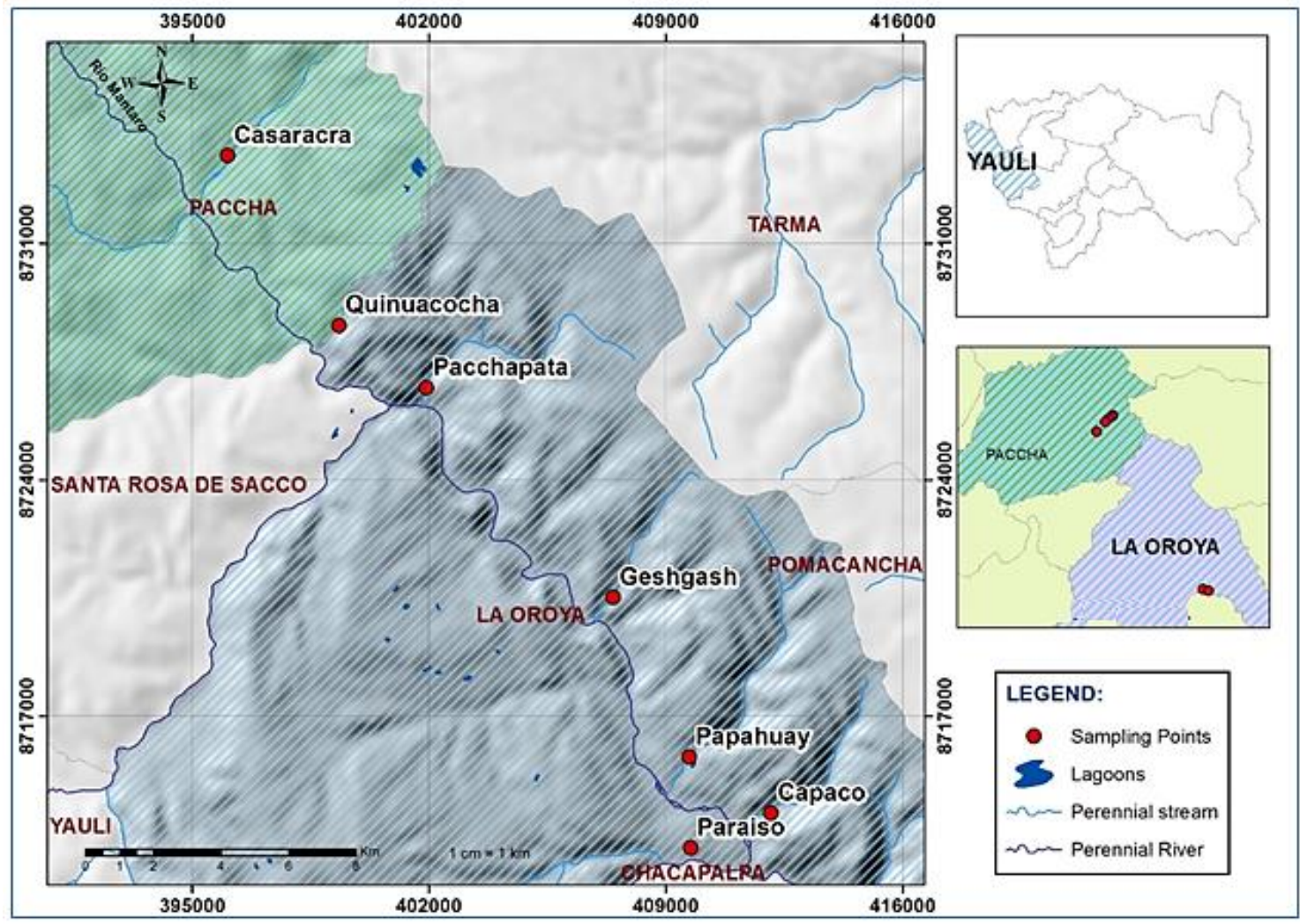

Figure 1. Location of sampling points in lotic systems with aptitude for aquaculture in the Mantaro River watershed. 


\subsection{Obtaining water samples}

The water samples were collected in two stages during the 2011-2013 periods. The first stage corresponded to the rainy season (January, February, March, and April) and, the second stage was during the dry season (May, June, July and August. During both stages, the surface water samples were collected in seven sampling sites, in triplicate (left margin, middle and right bank of the river) in the opposite direction to the flow of the stream at $30 \mathrm{~cm}$ depth, in two-liter plastic bottles, previously treated with a $10 \%$ nitric acid solution for 24 hours and rinsed with bidistilled water. Subsequently, $1.5 \mathrm{ml}$ of concentrated nitric acid was added to one liter of water from each of the samples for its preservation (APHA et al., 2012). For the determination of $\mathrm{BOD}_{5}$, water samples were collected in amber bottles, previously treated with 1:1 hydrochloric acid solution and rinsed with distilled water.

\subsection{Determination of the concentration of heavy metals in water}

The preparation of the sample consisted of placing $250 \mathrm{ml}$ of water in a beaker, which was boiled to obtain $100 \mathrm{ml}$. Immediately, $5 \mathrm{ml}$ of nitric acid and $5 \mathrm{ml}$ of ultra-pure hydrochloric acid (supplied by Merck Germany) were added to achieve complete oxidation and reduce the interference that organic matter could cause. The sample was then boiled again until the water was consumed. The sample was allowed to cool and then $10 \mathrm{ml}$ of distilled water was added, filtered and stocked in a $100 \mathrm{ml}$ vial, with $1 \%$ nitric acid (APHA et al., 2012).

The concentration of copper, zinc, iron, lead and arsenic (mg/L), was determined by the flame atomic absorption spectrophotometry method, according to the methodology recommended by the FAO (Nauen, 1983), using a Shimadzu-brand AA-6800 Atomic Absorption Spectrophotometer.

\subsection{Preparation of the calibration curve}

The standard solutions for $\mathrm{Pb} \mathrm{Cu}, \mathrm{Fe}, \mathrm{Zn}$ and As were supplied by Merck with the highest purity level (99.98\%). With the $1000 \mathrm{ppm}$ standard of $\mathrm{Pb}, \mathrm{Cu}, \mathrm{Fe}, \mathrm{Zn}$ and $\mathrm{As}$, an average standard of $100 \mathrm{ppm}$ concentration was prepared. Then the working standards of $0.001 ; 0.01$; $0.1 ; 1.0$ and $2.0 \mathrm{ppm}$, with $1 \%$ nitric acid. Next, the absorbance readings of the standards were performed at different wavelengths for each element in the atomic absorption spectrophotometer. Finally, the calibration curve was plotted: concentration vs absorbance and the concentration of the samples were read using the respective calibration curve.

\subsection{Determination of fish-fitness indicators}

The indicators of the fish fitness of the lotic systems under study determined in situ were: temperature, dissolved oxygen and $\mathrm{PH}$. Water samples were collected at the site using a water sampler for the detection of each of these indicators and their determination was made using Hanna Instruments portable equipment (HI 991301 Micro pH/ temperature, and HI 9146 Microprocessor dissolved oxygen). Previously, the equipment was calibrated at the respective sampling site. The determination of the $\mathrm{BOD}_{5}$ was made by the respirometric method with the OxiDirect Lovibond equipment.

\subsection{Analysis of data}

The normality and distribution of potentially toxic metals data in waters of rivers with aptitude for fish tributaries of the Mantaro River was analyzed; the data with exponential distributions (copper, iron and zinc) were transformed.

\subsubsection{Cluster Analysis (CA)}

This analysis belongs to the group of multivariate techniques whose purpose is to classify the available information based on certain characteristics they possess with respect to a 
predetermined selection criterion. It is expected that the resulting clusters should show high internal homogeneity (within the group) and high external heterogeneity (between clusters). We used the Ward method (minimum variance) that is within the agglomerative hierarchical approach, this being the most common approach. The dendrogram provides a visual summary of the grouping processes, presenting the groups and their proximities. The euclidean distance usually gives the similarity between two samples and a distance can be represented by the difference between the values of the samples (Everitt, 1980) Equation 1.

$$
d(x, y)=\sqrt{\sum_{i=1}^{p}\left(x_{i}-y_{i}\right)^{2}}
$$

In this study, a agglomerative hierarchical approach, rather than a divisive algorithm, was employed.

\subsubsection{Principal component analysis (PCA)}

PCA transforms the original variables into new, uncorrelated ones, called the principal components, which are linear combinations of the original variables so that the variation of the data can be explained as concisely as possible. The main components provide information on the most significant parameters, in a way that allows reducing the data without losing the original information. The main component can be expressed as Equation 2:

$$
z_{i j}=a_{i 1} x_{1 j}+a_{i 2} x_{2 j}+a_{i 3} x_{3 j}+\ldots+a_{i m} x_{m j}
$$

Where $\mathrm{z}$ is the value of the component, a is the coefficient of the component, $\mathrm{x}$ is the measure value of the variable, $i$ is the component number, $j$ is the number of the simple and $m$ is the total number of variables.

\subsubsection{Discriminant Analysis (DA)}

The discriminant analysis is the statistical method that allows discriminating and classifying the different data in groups. If the discriminant analysis is effective for a data gathering, the estimation classification table produces a high percentage of "correct" and the percentage of these is located on the diagonal of the table. The DA technique creates a discriminant function for each group that operates on data and constructs a discriminant function for each group (Heckler, 2005), as in the following Equation 3:

$$
f\left(G_{i}\right)=k_{i}+\sum_{j=1}^{n} w i_{j} \cdot p_{i j}
$$

Where $\mathbf{i}$ is the number of groups $(\mathrm{G}), \mathbf{k}_{\mathbf{i}}$ is the constant inherent in each group, $\mathbf{n}$ is the number of parameters used to classify a data set in a given group, $\mathbf{w}_{\mathbf{j}}$ is the weight coefficient, assigned by DA to certain selected parameters $\left(\mathbf{p}_{\mathbf{j}}\right)$.

In this study, the DA was performed with original data using the standard, step-by-step and backwards stepwise to evaluate both temporal and spatial variations of water quality. The river sectors and sampling periods were the grouping variables and the measured parameters were the independent variables.

\section{RESULTS AND DISCUSSION}

\subsection{Determination of the aptitude for aquaculture of lotic systems through physical- chemical indicators}

The results of the physical-chemical indicators of the water column of the seven rivers evaluated are presented in Table 1. 
Table 1. Descriptive statistics of physical-chemical indicators of water quality of rivers with aptitude for aquaculture evaluated during 2011-2013, in relation to the national environmental quality standards for water.

\begin{tabular}{|c|c|c|c|c|c|c|c|c|c|}
\hline Indicator & ED & Capaco & Casaracra & Geshgash & Pacchapata & Papahuay & Paraíso & Quinuacocha & MINEN \\
\hline \multirow{3}{*}{$\begin{array}{c}\text { pH } \\
\text { Unit }\end{array}$} & Range & $7.33-8.15$ & $7.22-8.10$ & $7.33-8.25$ & $7.40-8.13$ & $7.18-8.30$ & $7.50-8.30$ & $7.05-8.09$ & $6-9$ \\
\hline & Mean & 7.73 & 7.62 & 7.75 & 7.73 & 7.81 & 7.85 & 7.60 & \\
\hline & S.D & 0.22 & 0.22 & 0.26 & 0.17 & 0.24 & 0.20 & 0.25 & \\
\hline \multirow{3}{*}{$\begin{array}{c}\text { Temperature } \\
{ }^{\circ} \mathrm{C}\end{array}$} & Range & $10.20-11.60$ & $10.55-11.70$ & $10.60-11.75$ & $10.40-11.60$ & $10.50-11.40$ & $10.00-11.60$ & $10.55-11.75$ & $\Delta 3$ \\
\hline & Mean & 10.89 & 11.11 & 11.01 & 11.06 & 11.00 & 10.73 & 11.03 & \\
\hline & S.D & 0.36 & 0.32 & 0.29 & 0.30 & 0.28 & 0.47 & 0.31 & \\
\hline \multirow{3}{*}{$\begin{array}{c}\text { Dissolved Oxygen } \\
\mathrm{mg} / \mathrm{L}\end{array}$} & Range & $7.35-8.30$ & $7.45-8.20$ & $7.50-8.50$ & $7.42-8.23$ & $7.40-8.20$ & $7.25-8.10$ & $7.45-8.50$ & $\geq 5$ \\
\hline & Mean & 7.72 & 7.76 & 7.92 & 7.75 & 7.79 & 7.69 & 7.84 & \\
\hline & S.D & 0.21 & 0.18 & 0.27 & 0.22 & 0.23 & 0.17 & 0.25 & \\
\hline \multirow{3}{*}{$\begin{array}{l}\text { BOD }_{5} \\
\mathrm{mg} / \mathrm{L}\end{array}$} & Range & $7.00-8.00$ & $7.20-8.00$ & $7.00-8.05$ & $7.44-8.30$ & $7.38-8.10$ & $6.82-8.15$ & $7.45-8.05$ & 10 \\
\hline & Mean & 7.61 & 7.65 & 7.68 & 7.71 & 7.71 & 7.56 & 7.68 & \\
\hline & S.D & 0.19 & 0.18 & 0.24 & 0.17 & 0.16 & 0.29 & 0.15 & \\
\hline
\end{tabular}


The physical-chemical indicators of water are very important because they have a significant effect on water quality and aquatic life (Şener et al., 2017). The $\mathrm{pH}$ of the water presented variations with means that oscillated from $7.60 \pm 0.25$ in the Quinuacocha River to $7.85 \pm 0.20$ in the Paraíso River, with a maximum value of 8.30 . These variations would be related to the edaphic conditions through which the water currents pass (Munavalli an Mohan Kumar, 2005). Temperature, as the limiting factor of aquatic life, acquires great importance in the development of the different phenomena that are carried out in the water, since it determines the tendency of its physical properties and the composition of biological communities (Tyagi et al., 2013). The temperature of the water did not present important changes, although there was a slight increase in the Geshgash and Quinuacocha Rivers, with mean values that ranged from $10.73 \pm 0.47^{\circ} \mathrm{C}$ in the Paraiso River to $11.11 \pm 0.32^{\circ} \mathrm{C}$ in the Casaracra River. The indicators of organic matter associated with oxygen consumption in the seven rivers showed a similar behavior. The highest concentrations of dissolved oxygen were recorded in the Geshgash and Quinuacocha Rivers. However, the Geshgash River presented the highest average concentration. These results reveal the good level of oxygenation of the waters of these rivers that, together with the temperature, determine the richness and distribution patterns of the biological communities (Wronski et al., 2015). The mean concentration of $\mathrm{BDO}_{5}$ ranged from $7.56 \pm 0.29 \mathrm{mg} / \mathrm{L}$ in the Paraíso River to $7.71 \pm 0.17 \mathrm{mg} / \mathrm{L}$ in Pacchapata and Papahuay Rivers. All the results obtained from the physical-chemical indicators of water are in the range of environmental quality standards (EQS) for river waters of Peru, category two, subcategory four, referring to the extraction and cultivation of hydrological species in inland waters, and for category four, referring to the conservation of aquatic life.

\subsection{Determination of the concentration of potentially toxic metals in water}

The results of the concentration of potentially toxic metals are shown in Table 2 . The mean concentration of the metals studied followed the decreasing order of $\mathrm{Fe}>\mathrm{Zn}>\mathrm{Pb}>\mathrm{Cu}>\mathrm{As}$. The concentration of arsenic in the evaluated rivers ranged from 0.004 to $0.064 \mathrm{mg} / \mathrm{L}$, with the highest average concentrations being found in the Capaco Rivers $(0.032 \pm 0.009 \mathrm{mg} / \mathrm{L})$ and Paraíso $(0.032 \pm 0.012 \mathrm{mg} / \mathrm{L})$. However, in none of the rivers did the evaluated arsenic concentration exceed the EQS, category tow, subcategory four, referring to the extraction and cultivation of hydrobiological species of Ministry of the Environment (MINEN) (Perú, 2015) nor the standard referring to the protection of freshwater aquatic life of the United States Environmental Protection Agency (USEPA, 2006). The concentration of lead varied from 0.008 to $0.105 \mathrm{mg} / \mathrm{L}$, showing the highest average concentration of lead in the Capaco River $(0.043$ $\pm 0.021 \mathrm{mg} / \mathrm{L})$. In the seven rivers evaluated, the average lead concentration exceeded the national standards of the MINEN $(0.0025 \mathrm{mg} / \mathrm{L})$ and the USEPA limit $(0.01 \mathrm{mg} / \mathrm{L})$ referring to the protection of fish and aquatic life and the threshold level set by WHO $(0.003 \mathrm{mg} / \mathrm{L})$. The iron concentration ranged from 0.031 to $1.138 \mathrm{mg} / \mathrm{L}$, with the highest average concentration in the Geshgash River $(0.287 \pm 0.281 \mathrm{mg} / \mathrm{L})$. In all the rivers evaluated, the iron concentrations were higher than the national standards of the MINEN $(0.30 \mathrm{mg} / \mathrm{L})$ and those of the USEPA $(0.36 \mathrm{mg} / \mathrm{L})$. The zinc concentration ranged from 0.008 to $0.142 \mathrm{mg} / \mathrm{L}$, with the highest average concentration in the Capaco River $(0.071 \mathrm{mg} / \mathrm{L})$. The concentrations in all the rivers evaluated did not exceed the EQS for continental water $(1.00 \mathrm{mg} / \mathrm{L})$ destined for the extraction and cultivation of hydrobiological species. However, they exceeded the limit of the USEPA (2006) $(0.03 \mathrm{mg} / \mathrm{L})$. The copper concentration ranged from 0.002 to $0.127 \mathrm{mg} / \mathrm{L}$, with the highest average concentration in the Paraiso River $(0.043 \pm 0.032 \mathrm{mg} / \mathrm{L})$. However, no concentration of this metal recorded in all the rivers evaluated exceeded the EQS of the MINEN, category two, subcategory four, $(0.20 \mathrm{mg} / \mathrm{L})$. Nevertheless, the concentration of this metal widely exceeded the limits set by WHO $(0.003 \mathrm{mg} / \mathrm{L})$ and USEPA $(0.01 \mathrm{mg} / \mathrm{L})$. 
Table 2. Descriptive statistics of the concentration of heavy metals in river waters with aptitude for aquaculture assessed during 2011 2011-2013, in relation to national and international standards.

\begin{tabular}{|c|c|c|c|c|c|c|c|c|c|c|c|}
\hline $\begin{array}{c}\text { Metal } \\
(\mathrm{mg} / \mathrm{L})\end{array}$ & ED & Capaco & Casaracra & Geshgash & Pacchapata & Papahuay & Paraiso & Quinuacocha & Perú 2015 & $\begin{array}{c}\text { USEPA } \\
2006\end{array}$ & $\begin{array}{c}\text { WHO } \\
2011\end{array}$ \\
\hline \multirow{3}{*}{ Arsenic } & Range & $0.016-0.056$ & $0.008-0.046$ & $0.015-0.053$ & $0.005-0.042$ & $0.004-0.047$ & $0.011-0.064$ & $0.008-0.047$ & 0.10 & 0.34 & 0.01 \\
\hline & Average & 0.032 & 0.028 & 0.029 & 0.025 & 0.027 & 0.032 & 0.028 & & & \\
\hline & S.D & 0.009 & 0.012 & 0.010 & 0.010 & 0.011 & 0.012 & 0.013 & & & \\
\hline \multirow{3}{*}{ Lead } & Range & $0.024-0.098$ & $0.015-0.105$ & $0.019-0.054$ & $0.017-0.058$ & $0.008-0.056$ & $0.008-0.102$ & $0.013-0.061$ & 0.0025 & 0.01 & 0.003 \\
\hline & Average & 0.043 & 0.035 & 0.033 & 0.033 & 0.030 & 0.036 & 0.036 & & & \\
\hline & S.D & 0.021 & 0.018 & 0.011 & 0.011 & 0.011 & 0.020 & 0.012 & & & \\
\hline \multirow{3}{*}{ Iron } & Range & $0.053-0.423$ & $0.046-1.003$ & $0.071-1.138$ & $0.051-1.112$ & $0.035-0.322$ & $0.046-1.068$ & $0.031-0.492$ & 0.30 & 0.36 & --- \\
\hline & Average & 0.168 & 0.226 & 0.287 & 0.181 & 0.131 & 0.226 & 0.179 & & & \\
\hline & S.D & 0.096 & 0.214 & 0.281 & 0.211 & 0.071 & 0.238 & 0.129 & & & \\
\hline \multirow{3}{*}{ Zinc } & Range & $0.037-0.137$ & $0.033-0.142$ & $0.008-0.109$ & $0.015-0.122$ & $0.015-0.108$ & $0.014-0.106$ & $0.014-0.123$ & 1.00 & 0.03 & --- \\
\hline & Average & 0.071 & 0.067 & 0.049 & 0.053 & 0.064 & 0.056 & 0.052 & & & \\
\hline & S.D & 0.028 & 0.031 & 0.028 & 0.028 & 0.028 & 0.027 & 0.023 & & & \\
\hline \multirow{3}{*}{ Copper } & Range & $0.002-0.088$ & $0.005-0.072$ & $0.008-0.095$ & $0.005-0.041$ & $0.009-0.105$ & $0.007-0.127$ & $0.015-0.115$ & 0.20 & 0.01 & 0.003 \\
\hline & Average & 0.034 & 0.030 & 0.033 & 0.018 & 0.030 & 0.043 & 0.036 & & & \\
\hline & S.D & 0.022 & 0.019 & 0.020 & 0.009 & 0.021 & 0.032 & 0.022 & & & \\
\hline
\end{tabular}


The results obtained are supported by Singh et al. (2014), who report that aquatic organisms are exposed to various contaminants either through the water or the food they ingest. However, the uptake of heavy metals will depend on the total concentration and bioavailability of the metal, as well as physiological factors. Other research supporting the results indicate that concentrations of metals in fish organs depend on the actual level of contamination of the water they inhabit, and accumulation of metals in tissues may indicate levels of real metals in their environment (Poleksic et al., 2010; Jia et al., 2018).

\subsubsection{Cluster Analysis}

Custer analysis is a commonly used approach where clusters are formed sequentially starting with the most similar pair of objects and forming higher clusters step-by-step, and that the Euclidean distance usually gives similarities between two samples, and "distance" can be represented by the "difference" between the analytical values of both samples (Rencher, 2005). Cluster analysis was used to detect a group of rivers that had similar characteristics (spatial variability) and identify rivers with pollution problems (Tsai et al., 2016). Cluster analysis was performed based on the Bray and Curtis Index (1957) to detect groups of rivers evaluated that had similar characteristics and that have been affected by similar concentrations of potentially toxic metals. The hierarchical grouping of the rivers evaluated using the Ward method with the square Euclidean distance gave rise to a dendrogram made up of two clusters with minimal difference. The first cluster is formed by the Capaco, Papahuay and Paraíso Rivers, and the second by the Casaracra, Geshgash, Pacchapata and Quinuacocha Rivers (Figure 2).

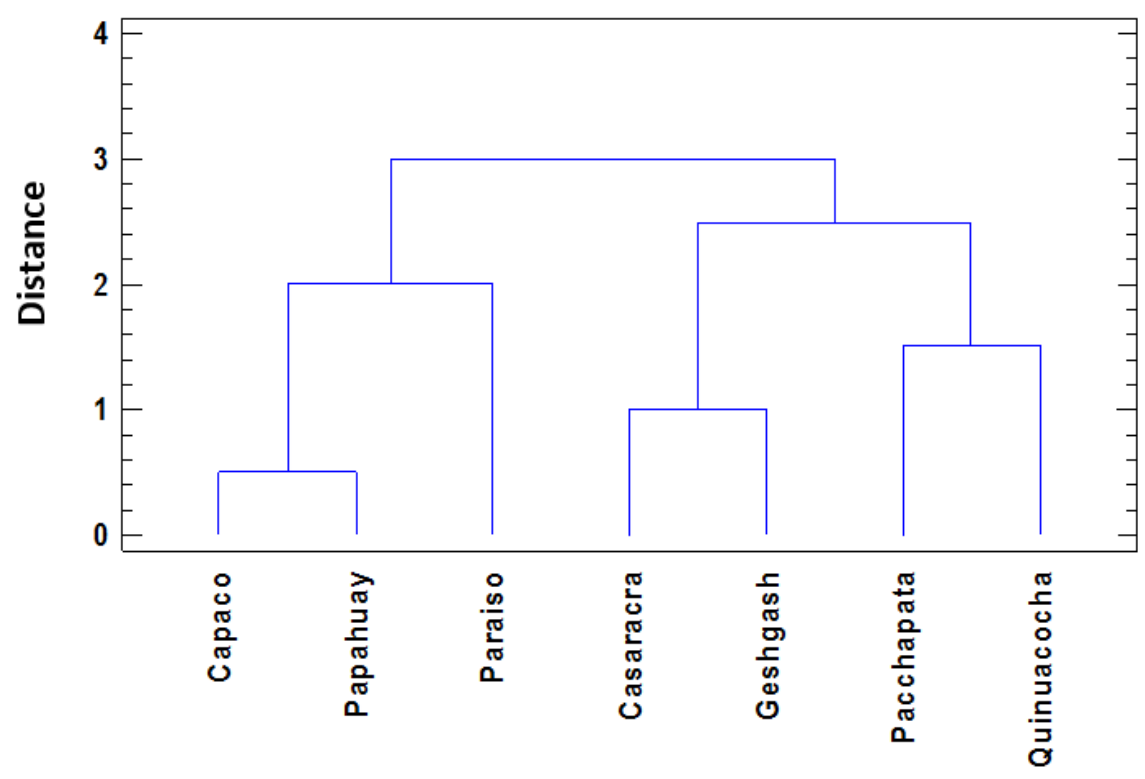

Figure 2. Dendrogram of similarity among rivers with aptitude for aquaculture according to the concentrations of heavy metals.

\subsubsection{Principal component analysis}

The results of the PCA are shown in Table 3 where the information of the components is summarized during the two sampling periods. In rainy season, the first two components absorb $53.53 \%$ of the variance of the PCA with eigenvalues greater than 1. Component 1 explains $28.92 \%$ of the total variance and Component 2 of $24.61 \%$. In the dry season, three components were explained by $73.69 \%$ of the variance of the PCA, with eigenvalues greater than 1 . In Component 1, there are moderate loads for arsenic that explains the variance of $30.96 \%$; in Component 2, there is a strong load for zinc and relatively low loads for iron; and in Component 
3 , there is a moderate load for iron. Therefore, the positive values of each component are related to important inputs, and the negative values correspond to low inputs (Barakat et al., 2016).

Table 3. PCA values and percentage of the variance of the main components and the relation of the variables, according to the sampling period.

\begin{tabular}{lccc}
\hline \multirow{2}{*}{ Variables } & \multicolumn{3}{c}{ Components } \\
\cline { 2 - 4 } & $\mathbf{1}$ & $\mathbf{2}$ & $\mathbf{3}$ \\
\hline Rainy season & & & \\
\hline $\mathrm{Cu}$ & 0.540 & -0.466 \\
$\mathrm{Zn}$ & 0.113 & -0.777 & \\
$\mathrm{Fe}$ & 0.320 & 0.177 & \\
$\mathrm{~Pb}$ & 0.513 & 0.155 & \\
$\mathrm{As}$ & 0.575 & 0.353 & \\
Own values & 1.45 & 1.23 & \\
$\%$ total variance & 28.92 & 24.61 & \\
$\%$ comulative variance & 28.92 & 53.53 & \\
\hline Drought season & & & \\
\hline $\mathrm{Cu}$ & 0.403 & 0.158 & 0.546 \\
$\mathrm{Zn}$ & -0.207 & $\mathbf{0 . 8 4 4}$ & 0.101 \\
$\mathrm{Fe}$ & -0.417 & -0.457 & 0.613 \\
$\mathrm{~Pb}$ & 0.435 & 0.119 & 0.504 \\
$\mathrm{As}$ & 0.657 & -0.199 & -0.247 \\
$\mathrm{Own}$ values & 1.55 & 1.14 & 1.00 \\
$\%$ total variance & 30.96 & 22.72 & 20.01 \\
$\%$ cumulative variance & 30.96 & 53.68 & 73.69 \\
\hline
\end{tabular}

\subsubsection{Discriminant Analysis}

This statistical method is designed to develop a set of discrimination functions which can help to differentiate between factors (rainy season and dry season) due to the use of quantitative variables. A total of 138 cases were used to develop a model that discriminates between the rainy and dry season. Using the forward- and backward-selection algorithm, it was determined that two of the five variables were significant predictors of the time, in this case, copper and lead are sufficient to discriminate the variables between the rainy season or the dry season. The discriminant function is statistically significant with a confidence level of 95.0\% (Table 4).

Table 4. Coefficients of the discriminant analysis of the temporal variation of the water quality of lotic systems with aptitude for aquaculture at the watershed of the Mantaro River.

\begin{tabular}{lcccccc}
\hline \multirow{2}{*}{ Variables } & \multicolumn{2}{c}{ All variables } & \multicolumn{2}{c}{$\begin{array}{c}\text { Step-by-step forward } \\
\text { selection }\end{array}$} & \multicolumn{2}{c}{$\begin{array}{c}\text { Step-by-step backward } \\
\text { selection }\end{array}$} \\
\cline { 2 - 7 } & Rain & Drought & Rain & Drought & Rain & Drought \\
\hline $\mathrm{Cu}$ & 63.337 & -1.225 & 160.361 & 97.666 & 160.361 & 97.666 \\
$\mathrm{Zn}$ & 103.882 & 108.985 & & & & \\
$\mathrm{Fe}$ & 22.276 & 19.592 & & & & \\
$\mathrm{~Pb}$ & 261.243 & 219.613 & 285.258 & 246.113 & 285.258 & 246.113 \\
$\mathrm{As}$ & 239.044 & 247.354 & & & & \\
Constant & -15.15 & -12.00 & -8.67 & -5.57 & -8.67 & -5.57 \\
\hline
\end{tabular}


Of the 138 observations used to adjust the model, 97 (70.29\%) of the total observations were correctly classified by the forward- and backward-step methods. While if we consider all the variables we obtain that $102(73.91 \%)$ of the data were correctly classified (Table 5).

Table 5. Classification matrix for the discriminant analysis of the temporal variation of the water quality of lotic systems with aptitude for aquaculture at the watershed of the Mantaro River.

\begin{tabular}{lccc}
\hline \multirow{2}{*}{ Rainy season } & \% accurate & \multicolumn{2}{c}{ Season assigned by the DA } \\
\cline { 3 - 4 } & & Rain & Drought \\
\hline All variables & & \\
\hline Rain & 68.75 & 44 & 20 \\
Drought & 78.38 & 16 & 58 \\
Total & 73.91 & 60 & 78 \\
\hline Step-by-step forward selection & & \\
\hline Rain & 68.75 & 44 & 20 \\
Drought & 71.62 & 21 & 53 \\
Total & 70.29 & 65 & 73 \\
\hline Step-by-step backward selection & & \\
\hline Rain & 68.75 & 44 & 20 \\
Drought & 71.62 & 21 & 53 \\
Total & 70.29 & 65 & 73 \\
\hline
\end{tabular}

Figure 3 shows the discriminant parameters recognized by DA related to the sampling times. The average concentration of $\mathrm{Zn}$ was slightly lower in the rainy season $\left(5.10 \times 10^{-02}\right)$ than in the dry season $\left(5.34 \times 10^{-02}\right)$. For $\mathrm{Cu}$, the average concentration was higher in the rainy season $\left(3.68 \times 10^{-04}\right)$ than in the dry season $\left(1.19 \times 10^{-04}\right)$ showing a marked effect on the sampling period. For the Fe, there was no marked effect with respect to the sampling period, where averages of $1.43 \times 10^{-01}$ were found for the rainy season and $1.28 \times 10^{-01}$ for the dry season. The average concentration of $\mathrm{Pb}$ had averages of $3.59 \times 10^{-02}$ and $3.10 \times 10^{-02}$ for the rainy and dry season, respectively; and, finally, the concentration of As, following the same pattern as $\mathrm{Cu}, \mathrm{Fe}$ and $\mathrm{Pb}$, were greater in the rainy season than in the dry season $\left(3.00 \times 10^{-02}\right.$ facing $2.66 \times 10^{-02}$ ). The lower concentration of $\mathrm{Zn}$ during the rainy season would be due to the dilution effect of water (Mohiuddin et al., 2012; Islam et al., 2015). Meanwhile, the highest concentrations $\mathrm{Cu}, \mathrm{Fe}, \mathrm{Pb}$ and $\mathrm{As}$ would be related to the influence of mining activity in the area (Kapia et al., 2016).

\section{CONCLUSIONS}

The results show that in the seven rivers evaluated the average concentration of $\mathrm{Pb}, \mathrm{Fe}$ and $\mathrm{Cu}$ exceeded the quality standards of Peru's continental water for the extraction and cultivation of hydrobiological species and USEPA standards for the protection of fish and aquatic life. The average concentration of $\mathrm{Zn}$ only exceeded USEPA standards, while the concentrations of $\mathrm{Pb}$ and $\mathrm{Cu}$ also surpassed those of the WHO.

The cluster analysis suggests that the rivers evaluated, in which the fish farming activity is intensively developed, have similar characteristics in relation to the concentration of heavy metals. According to the analysis of main components, in Component 1 , there are moderate loads for arsenic; in Component 2, there is a strong load for zinc and relatively low loads for iron; and, in Component 3, there is a moderate charge for iron. The discriminant analysis 
revealed that two of the five variables were significant predictors of the season in this case, copper and lead were sufficient to discriminate the variables between the rainy or dry season.

(a)

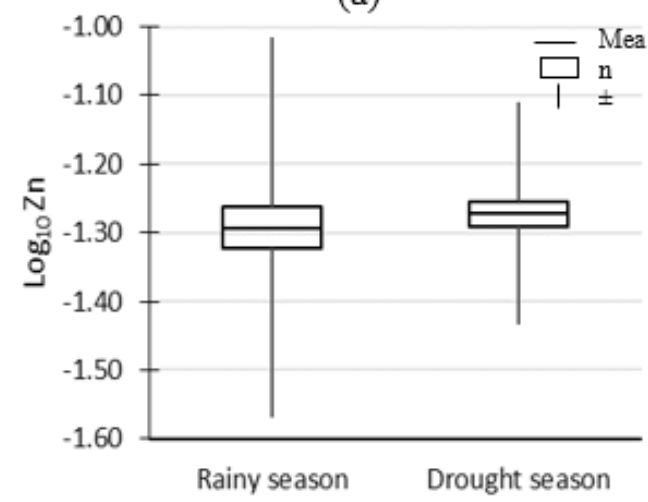

(c)

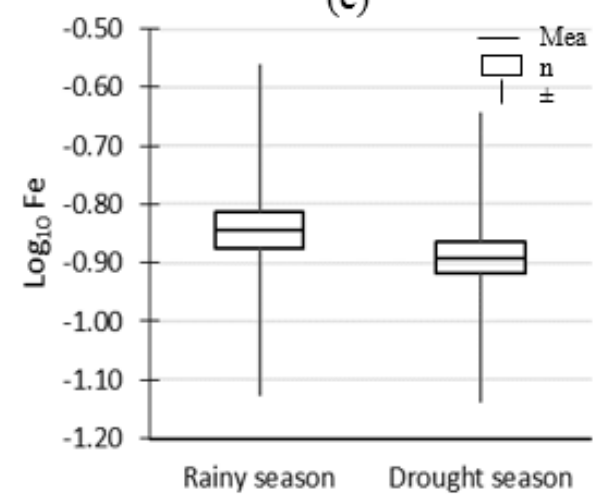

(b)

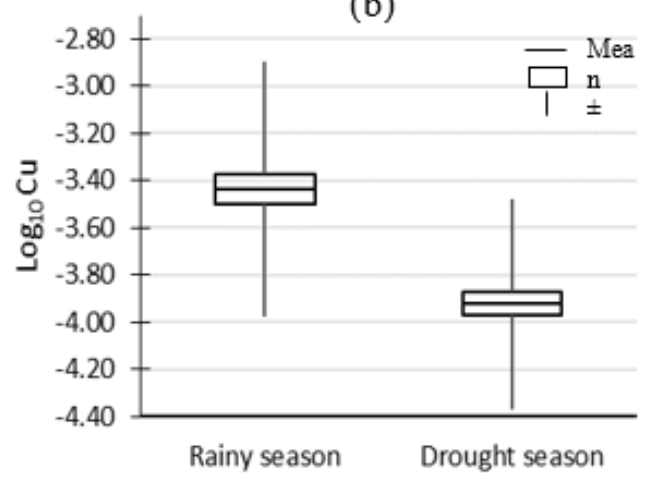

(d)

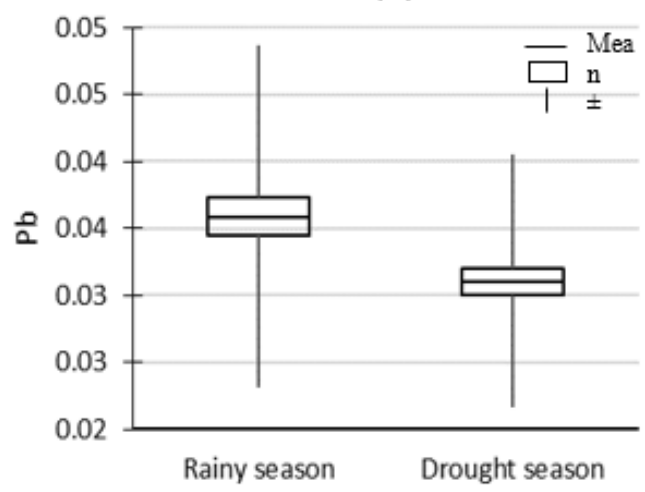

(e)

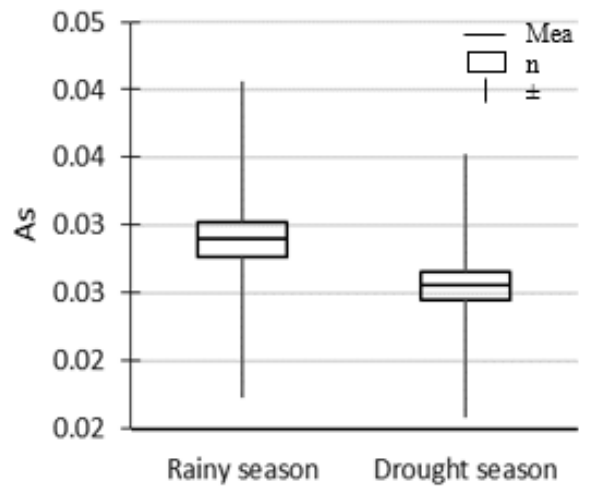

Figure 3. Temporal variability of heavy metals in river waters with aptitude for aquaculture, assessed during 2011-2013.

\section{REFERENCES}

APHA; AWWA; WEF. Standard Methods for the Examination of Water and Wastewater. $22^{\text {nd }}$ ed. Washington, D.C., 2012. 541 p.

BARAKAT, A.; EL BAGHDADI, M.; RAIS, J.; AGHEZZAF, B.; SLASSI, M. Assessment of spatial and seasonal water quality variation of Oum Er Rbia River (Morocco) using multivariate statistical techniques. International Soil and Water Conservation Research, v. 4, n. 4, p. 284-292, 2016. https://doi.org/10.1016/j.iswcr.2016.11.002 
CHANAMÉ, F.; CUSTODIO, M.; PANTOJA, R.; UNCHUPAICO, I. Bioaccumulation of heavy metals in Oncorhynchus mykiss for export at production centers in the Peruvian Central Highlands. Revista Ambiente \& Agua, v. 12, n. 4, p. 527-542, 2017. http://dx.doi.org/10.4136/ambi-agua.2100

EVERITT, B. Cluster Analysis. Quality and Quantity, v. 14, n. 1, 1980. https://doi.org/10.1007/BF00154794

GUNATILAKE, S. K. Methods of Removing Heavy Metals from Industrial Wastewater. Journal of Multidisciplinary Engineering Science Studies, v. 1, n. 1, p. 12-18, 2015.

HECKLER, C. E. Applied Multivariate Statistical Analysis. Technometrics, v. 47, n. 4, p. 517 , 2005. https://doi.org/10.1198/tech.2005.s319

ISLAM, M. S.; AHMED, M. K.; RAKNUZZAMAN, M.; HABIBULLAH-AL-MAMUN, M.; MASUNAGA, S. Metal Speciation in Sediment and Their Bioaccumulation in Fish Species of Three Urban Rivers in Bangladesh. Archives of Environmental Contamination and Toxicology, v. 68, n. 1, p. 92-106, 2015. https://doi.org/10.1007/s00244-014-0079-6

JIA, Y.; WANG, L.; QU, Z.; YANG, Z. Distribution, contamination and accumulation of heavy metals in water, sediments, and freshwater shellfish from Liuyang River, Southern China. Environmental Science and Pollution Research, v. 25, n. 7, p. 7012-7020, 2018. https://doi.org/10.1007/s11356-017-1068-X

KAPIA, S.; RAO, B. K. R.; SAKULAS, H. Assessment of heavy metal pollution risks in Yonki Reservoir environmental matrices affected by gold mining activity. Environmental Monitoring and Assessment, v. 188, n. 10, 2016. https://doi.org/10.1007/s10661-0165604-9

KWOK, C. K.; LIANG, Y.; WANG, H.; DONG, Y. H.; LEUNG, S. Y.; WONG, M. H. Bioaccumulation of heavy metals in fish and Ardeid at Pearl River Estuary, China. Ecotoxicology and Environmental Safety, v. 106, p. 62-67. 2014, https://doi.org/10.1016/j.ecoenv.2014.04.016

MOHIUDDIN, K. M.; OTOMO, K.; OGAWA, Y.; HIKAZONO, N. Seasonal and spatial distribution of trace elements in the water and sediments of the Tsurumi River in Japan. Environmental Monitoring and Assessment, v. 184, n. 1, p. 265-279, 2012. https://doi.org/10.1007/s10661-011-1966-1

MUNAVALLI, G. R.; MOHAN KUMAR, M. S. Water quality parameter estimation in a distribution system under dynamic state. Water Research, v. 39, n. 18, p. 4287-4298, 2005. https://doi.org/10.1016/j.watres.2005.07.043

NAUEN, C. E. Compilation of legal limits for hazardous substances in fish and fishery product. Roma: FAO, 1983. 102 p. (FAO Fish. Circ, 764).

PERÚ. Ministerio del Ambiente. Decreto Supremo N 015-2015-MINAM. El Peruano, 19 dic. 2015. Available en: http://www.minam.gob.pe/wp-content/uploads/2015/12/DecretoSupremo-Nº-015-2015-MINEN.pdf. Access: Dec. 2018.

POLEKSIC, V.; LENHARDT, M.; JARIC, I.; DJORDJEVIC, D.; GACIC, Z.; CVIJANOVIC, G. et al. Liver, gills, and skin histopathology and heavy metal content of the danube sterlet (Acipenser ruthenus Linnaeus, 1758). Environmental Toxicology and Chemistry, v. 29, n. 3, p. 515-521. 2010. https://doi.org/10.1002/etc.82 
RENCHER, A. C. A review of "Methods of Multivariate Analysis, Second Edition" IIE $\begin{array}{llllll}\text { Transactions, } & \text { v. } 37, \quad \text { n. } & 11, & \text { p. }\end{array}$ 2005.https://doi.org/10.1080/07408170500232784

ŞENER, Ş.; ŞENER, E.; DAVRAZ, A. Evaluation of water quality using water quality index (WQI) method and GIS in Aksu River (SW-Turkey). Science of the Total Environment, n. 584-585, p. 131-144, 2017. https://doi.org/10.1016/j.scitotenv.2017.01.102

SINGH, A. K.; SRIVASTAVA, S. C.; VERMA, P.; ANSARI, A.; VERMA, A. Hazard assessment of metals in invasive fish species of the Yamuna River, India in relation to bioaccumulation factor and exposure concentration for human health implications. Environmental Monitoring and Assessment, v. 186, n. 6, p. 3823-3836, 2014. https://doi.org/10.1007/s10661-014-3660-6

TSAI, Y. C.; CHUNG, C. Y.; CHUNG, C. C.; GAU, H. S.; LAI, W. L.; LIAO, S. W. The Impact of Typhoon Morakot on Heavy Metals of Dapeng Bay and Pollution from Neighboring Rivers. Environmental Modeling and Assessment, v. 21, n. 4, p. 479-487, 2016. https://doi.org/10.1007/s10666-015-9474-2

TYAGI, S.; SHARMA, B.; SINGH, P.; DOBHAL, R. Water Quality Assessment in Terms of Water Quality Index. American Journal of Water Resources, v. 1, n. 3, p. 34-38, 2013. https://doi.org/10.12691/ajwr-1-3-3

UNITED STATES. Environment Protect Agency - USEPA. National recommended water quality criteria. Washington, 2006. $21 \mathrm{p}$.

WASEEM, A.; ARSHAD, J.; IQBAL, F.; SAJJAD, A.; MEHMOOD, Z.; MURTAZA, G. Pollution Status of Pakistan: A Retrospective Review on Heavy Metal Contamination of Water, Soil, and Vegetables. BioMed Research International, v. 2014, 29 p., 2014. https://doi.org/10.1155/2014/813206

WORLD HEALTH ORGANIZATION - WHO. Guidelines for drinking-water quality. 4th ed. Amita Bhaduri, 2011. 564 p.

WRONSKI, T.; DUSABE, M. C.; APIO, A.; HAUSDORF, B.; ALBRECHT, C. Biological assessment of water quality and biodiversity in Rwandan Rivers draining into Lake Kivu. Aquatic Ecology, v. 49, n. 3, p. 309-320, 2015. https://doi.org/10.1007/s10452-0159525-4

ZUBIETA, R.; SAAVEDRA, M.; SILVA, Y.; GIRÁLDEZ, L. Spatial analysis and temporal trends of daily precipitation concentration in the Mantaro River basin: central Andes of Peru. Stochastic Environmental Research and Risk Assessment, v. 56, n. 6, p. 13051318, 2017. https://doi.org/10.1007/s00477-016-1235-5 


Ambiente \& Água - An Interdisciplinary Journal of Applied Science
ISSN 1980-993X - doi:10.4136/1980-993X
www.ambi-agua.net
E-mail: ambi.agua@gmail.com

\title{
Sewage sludge compost in zoysia grass sod production
}

\author{
ARTICLES doi:10.4136/ambi-agua.2301
}

Received: 19 Jul. 2018; Accepted: 01 Dec. 2018

\author{
Flávia Diniz Mota*iD; Roberto Lyra Villas Bôas ${ }^{(D}$; \\ Caroline de Moura D’Andréa Mateus $D^{\circledR}$; Tatiane Bortoletto Gomes da Silva \\ Universidade Estadual Paulista (UNESP), Botucatu, SP, Brasil \\ Faculdade de Ciências Agronômicas (FCA). Departamento de Solos e Recursos Ambientais. \\ E-mail: fdmota@yahoo.com.br, rlvboas@fca.unesp.br, caroline_mateus@hotmail.com, \\ tatibortoletto@live.com \\ *Corresponding author
}

\begin{abstract}
This study evaluated whether the use of composted sewage sludge in zoysia grass sod production can partially or completely substitute fertilization based on urea. The experiment was conducted on a sod farm located in Itapetininga, São Paulo State, Brazil. The experimental design was a complete randomized block design with five replications and experimental plots of $5 \mathrm{~m}^{2}$ in a $2 \times 6$ factorial scheme. The first factor was the method of application (single or split), and the second factor was composted sewage sludge fertilization and two controls (no fertilization and a standard dose of conventional fertilizer). The conventional fertilizer (urea) dose corresponds to $300 \mathrm{~kg} \mathrm{~N} \mathrm{ha}^{-1}$ and the sewage compost doses correspond to 100, 200, 300, and $400 \mathrm{~kg} \mathrm{~N} \mathrm{ha}^{-1}$. The experiment began with the liming of the total area at 60 days after the previous harvest of zoysia grass sod. Three methods were used to evaluate sod production: soil cover rate, green color intensity, and leaf analysis. At 212 days after the beginning of the experiment, the compost treatment of $30 \mathrm{Mg} \mathrm{ha}^{-1}\left(300 \mathrm{~kg} \mathrm{ha}^{-1}\right.$ of $\left.\mathrm{N}\right)$, applied in a single dose, allowed for complete sod formation (100\% soil cover rate).
\end{abstract}

Keywords: nitrogen, organic fertilization, soil cover rate, SPAD, turfgrass.

\section{Lodo de esgoto compostado na produção de grama esmeralda}

\section{RESUMO}

Objetivou-se com este trabalho avaliar se o uso de lodo de esgoto compostado na produção de grama esmeralda pode substituir parcial ou totalmente a adubação com uréia. O experimento foi conduzido em área de produção de grama, localizada em Itapetininga-SP. O delineamento experimental utilizado foi de blocos ao acaso, com cinco repetições e parcelas experimentais de $5 \mathrm{~m}^{2}$ em esquema fatorial $2 \times 6$, sendo o primeiro fator a forma de aplicação, parcelada e não parcelada e o segundo fator a adubação com lodo de esgoto compostado e duas testemunhas (sem adubação e dose usual de adubação inorgânica). A dose de adubo inorgânico foi correspondente a $300 \mathrm{~kg} \mathrm{~N} \mathrm{ha}^{-1}$ e as doses de lodo de esgoto compostado foram correspondentes a 100, 200, 300 e $400 \mathrm{~kg} \mathrm{~N} \mathrm{ha}^{-1}$. O início do experimento ocorreu 60 dias após a colheita dos tapetes de grama esmeralda, com a realização de calagem em área total. Foram utilizados três métodos para avaliar a produção do tapete de grama esmeralda: taxa de cobertura do solo, intensidade de cor verde e análise foliar. Aos 212 dias após o início do experimento, a adubação 
orgânica com lodo de esgoto compostado, na dose de $30 \mathrm{Mg} \mathrm{ha}^{-1}$ (300 $\mathrm{kg} \mathrm{ha}^{-1} \mathrm{de} \mathrm{N}$ ), aplicado de forma não parcelada, permitiu formação do tapete de grama (100\% taxa de cobertura do solo).

Palavras-chave: adubação orgânica, grama, nitrogênio, SPAD, taxa de cobertura do solo.

\section{INTRODUCTION}

The use of in natura or composted sewage sludge as a soil conditioner and source of nutrients for agricultural crops is an alternative disposal method for such waste that is used in several countries (Singh and Agrawal, 2008; Corradi et al., 2016). In Brazil, its use is regulated by Conama Resolution 375 (Conama, 2006), which limits the levels of acceptable pathogenicity for Class A sludge, thus making direct use of sewage sludge in agriculture unviable. However, it is legally possible to compost the sludge by mixing it with a carbon source to produce a Class D Compound Organic Fertilizer Product, according to the Ministry of Agriculture (MAPA) Federal Decree 4.954 of January 14, 2004 and Normative Instructions 23 from 08/31/2005 and 27 from 05/06/2006.

The composting process not only transforms the biodegradable material into humus, but also reduces and deactivates pathogens and reduces the concentration of heavy metals, thus making it adequate for use as a fertilizer to provide nutrients to the soil (Kiehl, 1985; Paredes Filho, 2011; Rashad et al., 2010).

The use of composted sewage sludge in the production of sod grass has previously been analyzed. For example, Angle et al. (1981) showed improvements related to quality, postharvest survival, and the production system for Kentucky bluegrass (Poa pratensis L.). Other studies corroborate these results (Schnell et al., 2009; Tesfamariam et al., 2009; Griffith et al., 2017).

Zoysia grass (Zoysia japonica) is the main species of grass cultivated in Brazil, and it currently covers approximately $80 \%$ of the total production area (Grama Legal National Association, 2017). The species is usually cultivated for use in landscaping projects, sports fields and along highways due to its resistance to drought and trampling, rapid rooting, and its adaptability to a tropical climate (Turfgrass Producers International, 2002; Gurgel, 2003).

Because of its stoloniferous-rhizomatous growth habit, zoysia grass shows high resistance to trampling and an elevated rate of soil cover. According to Li et al. (2011), rhizomes and stolons linked to nitrogen fertilization are responsible for the resistance and quality of the sod.

Nitrogen $(\mathrm{N})$ is the most important nutrient in the production of zoysia grass sod and is directly associated with shoot growth, increased green coloration, resistance, and soil cover rate. Although $\mathrm{N}$ demand varies with soil type, previous studies have shown that the best responses occur with $408 \mathrm{~kg} \mathrm{~N} \mathrm{ha}^{-1}$ per year for zoysia grass (Godoy et al., 2007) and $425 \mathrm{~kg}$ $\mathrm{N} \mathrm{ha}^{-1}$ per year for Kentucky bluegrass (Griffith et al., 2017).

Composted sewage sludge can present a $\mathrm{N}$ concentration of $10 \mathrm{~g} \mathrm{~kg}^{-1}$ based on dry matter. As such, it has the potential to fully satisfy the demand for this nutrient without the need for synthetic fertilizers and minerals (Singh and Agrawal, 2008; 2009; Mehrotra et al., 2016) in the production of zoysia grass sod. In addition to being rich in $\mathrm{N}$, and because it presents stabilized organic matter, organic compost has a direct impact on the physical and biological properties of the soil, since part of the applied biosolids will remain in the soil after the sod harvest (Schnell et al., 2009; De Maria et al., 2007).

In this context, this study aims to verify the effects of fertilization with composted sewage sludge on zoysia grass production, with the goal of partially or completely replacing the use of urea fertilization. Thus, herein we test four doses of this organic fertilizer. 


\section{MATERIALS AND METHODS}

The experiment was performed from April 2015 to December 2015, in a zoysia grass sod

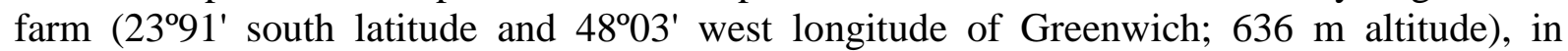
Itapetininga, São Paulo State, Brazil. The soil in the area is classified as Red Dystrophic Latosol (EMBRAPA, 2006) and the climate is classified as Cfa (subtropical) based on the KöppenGeiger System (Peel et al. 2007), with cold, dry winters, and hot, humid summers (Cunha and Martins, 2009).

We used a randomized block experimental design with five replications and experimental plots of $5 \mathrm{~m}^{2}$ in a 2x6 factorial scheme, with the first factor including two different methods of application (single or split application), and the second factor being type of fertilization treatment (Figure 1).

\begin{tabular}{|c|c|c|}
\hline \multirow[b]{2}{*}{31} & \multicolumn{2}{|c|}{ Block A } \\
\hline & $\mathrm{d} 3 \mathrm{a} 2$ & $\mathrm{~d} 3 \mathrm{a} 1$ \\
\hline 32 & d6a2 & $\mathrm{d} 2 \mathrm{a} 2$ \\
\hline 33 & $\mathrm{~d} 4 \mathrm{a} 2$ & dla2 \\
\hline 34 & d6al & dlal \\
\hline 35 & $\mathrm{~d} 5 \mathrm{al}$ & $\mathrm{d} 4 \mathrm{a} 1$ \\
\hline 36 & $\mathrm{~d} 5 \mathrm{a} 2$ & $\mathrm{~d} 2 \mathrm{a} 1$ \\
\hline
\end{tabular}

\begin{tabular}{|c|c|c|}
\hline \multirow[b]{2}{*}{19} & \multicolumn{2}{|c|}{ Block B } \\
\hline & dlal & dla2 \\
\hline 20 & $\mathrm{~d} 2 \mathrm{a} 1$ & $\mathrm{~d} 2 \mathrm{a} 2$ \\
\hline 21 & d3al & $\mathrm{d} 3 \mathrm{a} 2$ \\
\hline 22 & $\mathrm{~d} 4 \mathrm{a} \mathrm{l}$ & $\mathrm{d} 4 \mathrm{a} 2$ \\
\hline 23 & d5al & $\mathrm{d} 5 \mathrm{a} 2$ \\
\hline 24 & d6al & d6a2 \\
\hline
\end{tabular}

\begin{tabular}{|c|c|c|}
\hline \multirow[b]{2}{*}{7} & \multicolumn{2}{|c|}{ Block C } \\
\hline & dla2 & $\mathrm{d} 6 \mathrm{a} 2$ \\
\hline 8 & d6al & $\mathrm{d} 5 \mathrm{a} 2$ \\
\hline 9 & $\mathrm{~d} 2 \mathrm{a} 2$ & $\mathrm{~d} 5 \mathrm{al}$ \\
\hline 10 & $\mathrm{~d} 4 \mathrm{a} 2$ & $\mathrm{~d} 3 \mathrm{a} 2$ \\
\hline 11 & $\mathrm{~d} 2 \mathrm{a} 1$ & d3al \\
\hline 12 & $\mathrm{~d} 4 \mathrm{a} 1$ & dlal \\
\hline
\end{tabular}

$\mathrm{d}=$ Dose

\begin{tabular}{|c|c|c|}
\hline \multirow[b]{2}{*}{43} & \multicolumn{2}{|c|}{ Block D } \\
\hline & $\mathrm{d} 2 \mathrm{a} 2$ & $\mathrm{~d} 4 \mathrm{a} 2$ \\
\hline 44 & $\mathrm{~d} 6 \mathrm{a} 2$ & $\mathrm{~d} 3 \mathrm{a} 2$ \\
\hline 45 & $\mathrm{~d} 1 \mathrm{a} 2$ & $\mathrm{~d} 4 \mathrm{al}$ \\
\hline 46 & $\mathrm{~d} 5 \mathrm{a} 2$ & dlal \\
\hline 47 & d3al & $\mathrm{d} 5 \mathrm{al}$ \\
\hline 48 & d6al & $\mathrm{d} 2 \mathrm{al}$ \\
\hline
\end{tabular}

\begin{tabular}{|c|c|c|}
\hline \multirow[b]{2}{*}{55} & \multicolumn{2}{|c|}{ Block E } \\
\hline & $\mathrm{d} 4 \mathrm{a} 2$ & d6al \\
\hline 56 & $\mathrm{~d} 2 \mathrm{a} 2$ & $\mathrm{~d} 3 \mathrm{a} 2$ \\
\hline 57 & $\mathrm{~d} 5 \mathrm{a} 2$ & dlal \\
\hline 58 & dla2 & $\mathrm{d} 2 \mathrm{al}$ \\
\hline 59 & d5al & $\mathrm{d} 4 \mathrm{al}$ \\
\hline 60 & d6a2 & d3al \\
\hline
\end{tabular}

$\mathrm{a}=$ Application

Figure 1. Graphical schema of experiment.

To assess the effects of fertilization on zoysia grass sod production, the treatments included: urea; sewage sludge compost (SSC) in four different doses $\left(10,20,30\right.$ and $40 \mathrm{tha}^{-1}$ of compost sewage sludge, dry weight), based on the requirement of $\mathrm{N}(100,200,300$ and 400 $\mathrm{kg} \mathrm{N} \mathrm{ha}^{-1}$ ); and a control (no fertilizer). Four treatments received a single application of the SCC fertilizer and the other treatments included two applications: 50\% of the SSC at the beginning of the experiment and a second application after reaching a soil cover rate of $50 \%$. The sewage sludge compost came from the sewage treatment facility in Jundiaí, São Paulo State (Table 1). 
Table 1. Chemical composition of the sewage sludge compost.

\begin{tabular}{lc}
\hline Parameter & Concentration $^{(1)}$ \\
\hline Nitrogen $\left(\mathrm{g} \mathrm{kg}^{-1}\right)$ & 10.7 \\
Phosphorus $\left(\mathrm{g} \mathrm{kg}^{-1}\right)$ & 6 \\
Organic Carbon $\left(\mathrm{g} \mathrm{kg}^{-1}\right)$ & 165 \\
Potassium $\left(\mathrm{mg} \mathrm{kg}^{-1}\right)$ & 8452 \\
Total Solids $(\%)$ & 69.8 \\
Volatile Compounds (\%) & 30.0 \\
$\mathrm{pH}$ & 8.6 \\
Humidity (\%) & 27.2 \\
Cation Exchange Capacity $\left(\mathrm{mmol}_{\mathrm{c}} \mathrm{kg}^{-1}\right)$ & 314 \\
C:N Ratio & 15 \\
\hline (1) Except for humidity, results are expressed based on dry \\
weight.
\end{tabular}

Liming of the total area was conducted by applying $1.2 \mathrm{t} \mathrm{ha}^{-1}$ of dolomitic limestone (PRNT 95\%) and was based on the soil base saturation of the experimental area. At 60 days after the previous turfgrass sod harvest, the single application fertilization was applied. The first application of the split application was also applied at that time with the second application occurring at 127 days after the first, when the soil cover rate (SCR) reached 50\%. In the plots treated with urea, a dose of $300 \mathrm{~kg} \mathrm{~N} \mathrm{ha}^{-1}$ was given in a single application, corresponding to $670 \mathrm{~kg} \mathrm{ha}^{-1}$, at 25 days after the beginning of the experiment.

Three methods were used to evaluate zoysia grass sod production: soil cover rate (SCR), green color intensity (GCI), and leaf nitrogen content analysis.

Soil cover rate (SCR) was assessed through a digital image. The images were taken parallel to the lawn surface with a 3.0-megapixel digital camera coupled to a lightbox, similar to that described in Peterson et al. (2011), which standardizes the lighting and the image area. Subsequently, images were analyzed in Sigma Scan software and the SCR percentage was obtained by counting green pixels.

Green color intensity (GCI) was obtained using the non-destructive absorbance method in a portable Chlorophyll Meter, Soil and Plant Analysis Development (SPAD) Model 502 (Minolta Co., Osaka, Japan). Leaves were collected from each plot, placed in plastic bags, and stored in a Styrofoam box with ice for transportation to the laboratory. Shortly after arrival at the laboratory, the leaves were hydrated and a reading taken for each leaf, with 30 leaves analyzed per plot, to obtain an average value per treatment. SCR and GCI were measured at 45, 93, 127, and 156 days after application (DAA) of sewage sludge compost.

For the analysis of leaf nitrogen content, grass was cut in the plots and the shavings were ground and sent to the Plant Nutrition Laboratory in the Soils and Environmental Resources Department/Unesp, following a modified methodology based on Malavolta et al. (1997). Analyses were performed at 93 and 156 DAA of sewage sludge compost.

Data were submitted to analysis of variance and regression methods. Nitrogen dose effects were compared using Tukey's test, with $p=0.05$. Statistical analyses were performed using the software Minitab16.

\section{RESULTS AND DISCUSSION}

Soil cover rate (SCR) of zoysia grass showed significant interaction between dose and application at only 45 and 156 DAA of composted sludge $(p<0.05)$ (Table 2). According to Godoy (2007), soil cover rate is the first indicator in the formation of turfgrass sod. 
Table 2. Means and summary of analysis of variance of soil cover rate (SCR) (n=5).

\begin{tabular}{|c|c|c|c|c|c|c|c|c|}
\hline \multicolumn{9}{|c|}{ Soil Cover Rate (\%) } \\
\hline Doses of SSC & \multicolumn{2}{|c|}{45 DAA } & \multicolumn{2}{|c|}{93 DAA } & \multicolumn{2}{|c|}{127 DAA } & \multicolumn{2}{|c|}{156 DAA } \\
\hline $\mathrm{Mg} \mathrm{ha}^{-1}$ & \multicolumn{8}{|c|}{ Application } \\
\hline & 1 & 2 & 1 & 2 & 1 & 2 & 1 & 2 \\
\hline 0 & $18.5 b$ & $19.0 \mathrm{a}$ & 27.9 & 35.6 & 56.6 & 62.8 & $60.9 \mathrm{Abc}$ & $49.7 \mathrm{Bb}$ \\
\hline 10 & $24.6 \mathrm{~b}$ & $20.0 \mathrm{a}$ & 32.9 & 37.3 & 61.5 & 60.3 & $59.3 b c$ & $55.6 \mathrm{~b}$ \\
\hline 20 & $27.2 b$ & $22.2 \mathrm{a}$ & 30.9 & 29.3 & 65.1 & 62.8 & 75.0Aab & 64.2Bab \\
\hline 30 & $31.8 \mathrm{~b}$ & $22.2 \mathrm{a}$ & 30.1 & 26.6 & 66.9 & 58.7 & 82.4Aa & 63.0Bab \\
\hline 40 & 48.7Aa & $22.5 \mathrm{Ba}$ & 39.6 & 31.1 & 66.7 & 62.4 & $90.0 \mathrm{Aa}$ & $72.0 \mathrm{Ba}$ \\
\hline \multirow[t]{2}{*}{ Urea } & $18.3 b$ & & 36.8 & & 68.9 & & $68.7 \mathrm{c}$ & \\
\hline & & & & & & $\mathrm{p}$ & & \\
\hline Dose (D) & \multicolumn{2}{|c|}{0.0001} & \multicolumn{2}{|c|}{0.547} & \multicolumn{2}{|c|}{0.841} & \multicolumn{2}{|c|}{0.0001} \\
\hline Application (A) & \multicolumn{2}{|c|}{0.0001} & \multicolumn{2}{|c|}{0.953} & \multicolumn{2}{|c|}{0.248} & \multicolumn{2}{|c|}{0.0001} \\
\hline $\mathrm{D} \times \mathrm{A}$ & \multicolumn{2}{|c|}{0.001} & \multicolumn{2}{|c|}{0.713} & \multicolumn{2}{|c|}{0.721} & \multicolumn{2}{|c|}{0.032} \\
\hline C.V (\%) & \multicolumn{2}{|c|}{29.00} & \multicolumn{2}{|c|}{36.7} & \multicolumn{2}{|c|}{25.45} & \multicolumn{2}{|c|}{5.58} \\
\hline
\end{tabular}

Means followed by the same lowercase letters in the column and uppercase letters in the rows do not differ statistically based on a Tukey test.

1 - Single application; 2 - Split application.

Splitting the composted sludge into two applications showed no advantage compared to the single application at all sampling times for SCR. An explanation for this effect arises from the fact that a greater mass of organic matter in the soil retains a greater volume of water, especially during periods without rain. Another factor that may have contributed to this result is the period required for decomposition of the second portion of the sludge compound applied in November. The amount of time may not have been sufficient to release all nutrients. According to the nutrient evaluation conducted by Backes et al. (2013), 67\% of the $\mathrm{N}$ is released within a period of up to 120 days. Meanwhile, Godoy et al. (2007) note the need for basic fertilization for shoot development to begin.

The largest applied dose $\left(40 \mathrm{Mg} \mathrm{ha}^{-1}\right)$ provided a maximum coverage rate (SCR 100\%) at 212 DAA. Backes et al. (2009), in their study to verify non-composted sewage sludge doses in zoysia grass sod production, found that a single application of $40 \mathrm{Mg} \mathrm{ha}^{-1}$ produced the maximum coverage rate at 165 DAA. Meanwhile, in a different study, Backes et al. (2013) evaluated the effects of composted sewage sludge on the production of zoysiagrass and found that a dose of $46.8 \mathrm{Mg} \mathrm{ha}^{-1}$ produced the maximum SCR only at 380 DAA. These results suggest that the addition of a carbon source during the sewage sludge composting process dilutes the nutrients in the sludge, thus requiring a higher dose to reach the maximum SCR.

Plots that received syntetic fertilization (SF) showed a SCR of approximately $21 \%, 12 \%$, $10 \%$ and $29 \%$ lower in comparison to the highest dose of applied sludge. Backes et al. (2013), comparing a dose of $48 \mathrm{Mg} \mathrm{ha}^{-1}$ of sludge with a control (no fertilization), showed a lower SCR by $61 \%$ and $65 \%$ at 45 and 130 DAA, respectively.

At 127 DAA, treatments with SF provided an SCR 2.2\% greater than the highest dose of applied SSC, and at 156 DAA the highest SSC dose showed a $20 \%$ increase over IF (Figure 2). This result can be directly related to the effect of soil moisture, which favors the decomposition of organic matter and slows the release of nutrients with the application of the SSC in comparison to urea. 


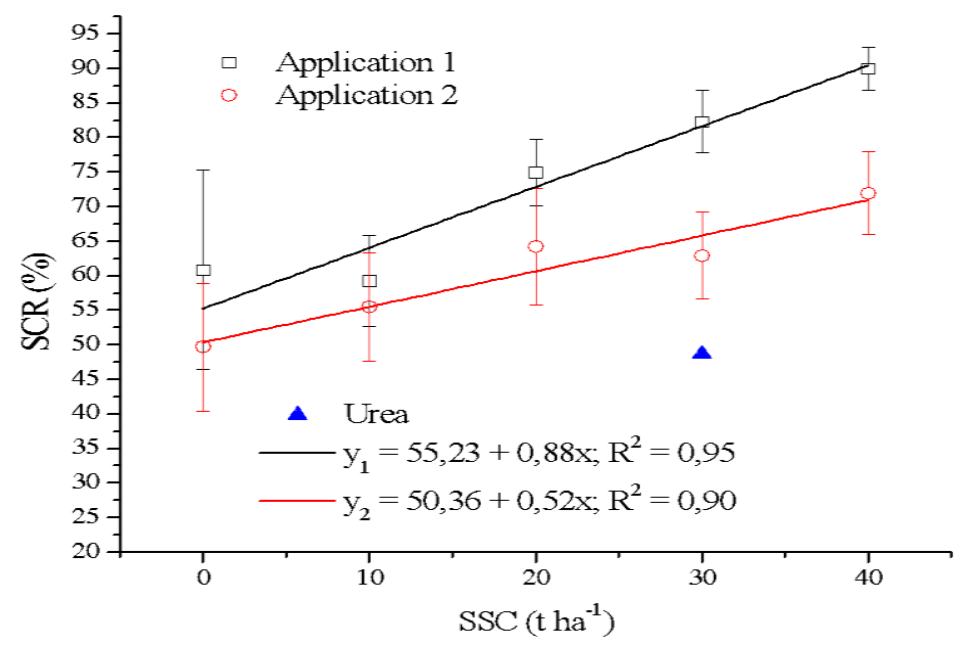

Figure 2. Soil Cover Rate (SCR) for zoysia grass as a function of the sewage sludge compost doses, urea, and methods of application, at 156 days after application (DAA) of sludge compost.

Green color intensity (GCI), represented by the SPAD value, is directly related to the concentration of chlorophyll in the leaves, representing a higher production of carbohydrates and quick rooting of the sod after planting (Christians, 1998). The doses of composted sewage sludge and the two methods of application significantly influenced the GCI at 45 and 93 days after application. At 127 DAA of composted sewage sludge, a significant effect was observed only for the applied doses (Table 3).

Table 3. Means and summary of analysis of variance of green color intensity (GCI) (n=5).

\begin{tabular}{|c|c|c|c|c|c|c|c|c|c|c|}
\hline \multicolumn{11}{|c|}{ Green Color Intensity (SPAD) } \\
\hline & \multicolumn{2}{|c|}{45 DAA } & \multicolumn{3}{|c|}{93 DAA } & \multicolumn{3}{|c|}{127 DAA } & \multicolumn{2}{|c|}{156 DAA } \\
\hline Doses of SSC & \multicolumn{10}{|c|}{ Application } \\
\hline $\mathrm{Mg} \mathrm{ha}^{-1}$ & 1 & 2 & 1 & 2 & Mean & 1 & 2 & Mean & 1 & 2 \\
\hline 0 & $27.9 \mathrm{Ac}$ & $27.0 \mathrm{Aa}$ & 26.9 & 27.4 & $27.1 \mathrm{~b}$ & 26.5 & 26.1 & $26.3 \mathrm{~b}$ & 27.8 & 27.2 \\
\hline 10 & $30.4 \mathrm{Abc}$ & $28.7 \mathrm{Aa}$ & 28.4 & 29.3 & $28.8 \mathrm{ab}$ & 27.6 & 25.9 & $26.7 \mathrm{ab}$ & 26.6 & 25.6 \\
\hline 20 & $31.6 \mathrm{Abc}$ & $28.7 \mathrm{Aa}$ & 28.6 & 27.4 & $28.0 \mathrm{ab}$ & 27.8 & 26.9 & $27.3 \mathrm{ab}$ & 26.8 & 26.7 \\
\hline 30 & 35.0 Aab & $30.7 \mathrm{Aa}$ & 31.5 & 29.2 & $30.3 \mathrm{a}$ & 29.0 & 29.2 & $29.1 \mathrm{ab}$ & 27.7 & 27.1 \\
\hline 40 & $37.0 \mathrm{Aa}$ & $30.5 \mathrm{Ba}$ & 32.4 & 28.8 & $30.6 \mathrm{a}$ & 31.7 & 26.9 & $29.3 \mathrm{a}$ & 29.5 & 28.6 \\
\hline Mean & & & $29.5^{\mathrm{a}}$ & 28.4B & & 28.5 & 27.0 & & & \\
\hline Urea & $27.6 \mathrm{Ac}$ & - & 28.8 & - & 28.8 Aab & 26.4 & - & $26.4 \mathrm{ab}$ & 25.5 & - \\
\hline \multicolumn{11}{|c|}{$\mathrm{p}$} \\
\hline Dose (D) & \multicolumn{2}{|c|}{0.0001} & \multicolumn{3}{|c|}{0.004} & \multicolumn{3}{|c|}{0.016} & \multicolumn{2}{|c|}{0.320} \\
\hline Application (A) & \multirow{2}{*}{\multicolumn{2}{|c|}{$\begin{array}{c}0.0001 \\
0.007\end{array}$}} & \multirow{2}{*}{\multicolumn{3}{|c|}{$\begin{array}{l}0.026 \\
0.221\end{array}$}} & \multicolumn{3}{|c|}{0.071} & \multicolumn{2}{|c|}{0.820} \\
\hline D x A & & & & & & \multicolumn{3}{|c|}{0.119} & \multicolumn{2}{|c|}{0.914} \\
\hline C.V (\%) & \multicolumn{2}{|c|}{. } & \multicolumn{3}{|c|}{7.85} & \multicolumn{3}{|c|}{8.37} & \multicolumn{2}{|c|}{11.23} \\
\hline
\end{tabular}

Means followed by the same lowercase letters in the column and uppercase letters in the rows do not differ statistically based on Tukey test.

1 - Single application; 2 - Split application. 
At 45 DAA, GCI can be expressed as a linear model that increases with an increase in the applied sludge dose: $\left(\mathrm{y}_{1}=27.83+0.23 \mathrm{x}, \mathrm{r}^{2}=0.99\right)$ and $\left(\mathrm{y}_{2}=27.14+0.09 \mathrm{x}, \mathrm{r}^{2}=0.90\right)$, split application and single application, respectively.

We also found that GCI at 45 days after application was greater in relation to the other evaluated time periods, due to a greater release of $\mathrm{N}$ until that date, corroborating the results found by Backes et al. (2010). At 45 DAA, we observed green color indices ranging from 27.9 to 37 SPAD units, which supports the concept that beginning from a $\mathrm{N}$ deficiency situation there is a linear response of GCI with increasing doses (Fig. 2), related to increasing chlorophyll content of the grass (Carvalho et al., 2003). Unlike the results observed for SCR, we found statistical differences between the treatments for doses and application method, with the highest values (35 and 37 SPAD) obtained with a single application of SSC for doses of 30 and $40 \mathrm{Mg}$ $\mathrm{ha}^{-1}$, as shown in Table 3. As the GCI is correlated with levels of N, we can infer that with an applied dose of $30 \mathrm{Mg} \mathrm{ha}^{-1}$, the zoysia grass reached the maximum value of $\mathrm{N}$, and this may indicate an optimal dose for this parameter.

The assessment at 156 DAA did not present statistically different results; however, it was possible to observe differences in soil cover (SCR, presented in Table 2) and, consequently, plant mass. This fact could have generated a uniformity in GCI results, since treatments with a greater dose of composted sludge showed increased plant growth. As such, $\mathrm{N}$ was diluted in the aerial part of the plant, which caused a decrease in concentration in comparison with the control or lower doses of SSC. Beard (1973) observed the effect of dilution on chlorophyll concentration when very high doses of $\mathrm{N}$ were used, leading to a reduced GCI.

GCI varied throughout the experiment, ranging from 27 to 37 SPAD. Our findings indicate that zoysia grass that received high doses of $\mathrm{N}$ achieved a GCI greater than 37 SPAD units at 90, 192, and 296 days after cutting (DAC). However, when no N was applied, the GCI ranged from 22.9 to 28.9 at 124,192 , and 296 DAC.

Our data suggest a significant interaction between dose and application for mean $\mathrm{N}$ leaf concentration at 93 and 156 days after application (Table 4).

Table 4. Means and summary of analysis of variance of foliar leaf $\mathrm{N}$ concentration $(\mathrm{n}=5)$.

\begin{tabular}{lcccc}
\hline \multicolumn{5}{c}{ Foliar leaf N concentration $\left(\mathrm{g} \mathrm{kg}^{-1}\right)$} \\
\hline \multicolumn{5}{c}{$93 \mathrm{DAA}$} \\
\hline Doses of SSC & \multicolumn{5}{c}{ Application } \\
\cline { 2 - 5 } $\mathrm{Mg} \mathrm{ha}^{-1}$ & $156 \mathrm{DAA}$ \\
\hline 0 & $10.39 \mathrm{c}$ & 10.85 & 13.89 & 12.93 \\
10 & $12.19 \mathrm{bc}$ & 11.86 & 12.64 & 10.22 \\
20 & $13.64 \mathrm{bc}$ & 11.52 & 14.74 & 12.74 \\
30 & $14.71 \mathrm{Ab}$ & $11.21 \mathrm{~B}$ & 12.74 & 10.13 \\
40 & $18.95 \mathrm{Aa}$ & $12.81 \mathrm{~B}$ & 15.03 & 11.72 \\
\hline Urea & $10.21 \mathrm{c}$ & - & 11.68 \\
\hline \multicolumn{5}{c}{$\mathrm{p}$} \\
\hline Dose (D) & \multicolumn{5}{c}{-} \\
Application (A) & 0.001 & 0.505 \\
D x A & 0.001 & 0.058 \\
\hline C.V (\%) & 0.001 & 0.937 \\
\hline
\end{tabular}

Means followed by the same lowercase letters in the column and uppercase letters in the rows do not differ statistically based on Tukey test.

1 - Single application; 2 - Split application. 
We observed a linear increase in the $\mathrm{N}$ concentration in leaf blades $(\mathrm{y}=9.59+0.23 \mathrm{x}$, $\left.\mathrm{R}^{2}=0.97\right)$, reaching a maximum value of $18.95 \mathrm{~g} \mathrm{~kg}^{-1}$ at 93 DAA with a single dose treatment of $40 \mathrm{Mg} \mathrm{ha}^{-1}$ composted sewage sludge (Table 4). Experiments performed in the field and in greenhouses, with the application of in natura and composted sewage sludge, also showed a linear increase in nitrogen concentration in leaf blades (Backes et al., 2010; Tester, 1989).

The maximum value found for $\mathrm{N}$ is slightly below the ideal range of 20 to $24 \mathrm{~g} \mathrm{~kg}^{-1}$, as suggested by Mills and Jones (1996). Backes et al. (2010), studying the effects of in natura sewage sludge, found a $\mathrm{N}$ concentration of $28 \mathrm{~g} \mathrm{~kg}^{-1}$ at 105 DAA.

At $156 \mathrm{DAA}$, with the dose of $40 \mathrm{Mg} \mathrm{ha}^{-1}$, we found a $\mathrm{N}$ concentration in the leaf blade of $15.03 \mathrm{~g} \mathrm{~kg}^{-1}$, which provided the highest SCR of 90\%. At 105 DAA, Backes et al. (2009) found that a foliar leaf $\mathrm{N}$ concentration of $17 \mathrm{~g} \mathrm{~kg}^{-1}$ provided more than $95 \%$ of SCR and at 165 DAA the concentration range was from 19 to $22 \mathrm{~g} \mathrm{~kg}^{-1}$.

From the results, we can infer that, due to the dilution effect, there is a tendency toward a decrease in the nutrient concentration in the leaf throughout the cycle, where a redistribution of $\mathrm{N}$ occurs with an increase in the total plant mass. The management of the lawn including the trimming and removal of cuttings, and the consequent removal of nutrients, also explains the reduction in concentration of $\mathrm{N}$ at $156 \mathrm{DAA}$. For this study, a dose of $30 \mathrm{Mg} \mathrm{ha}^{-1}$ can be considered optimum, since the increase in SPAD value of approximately 5\% does not justify increasing the dose to $40 \mathrm{Mg} \mathrm{ha}^{-1}$, considering the costs of production.

\section{CONCLUSIONS}

A $30 \mathrm{Mg} \mathrm{ha}^{-1}$ dose of sewage sludge compost is the most suitable for sod production.

A divided application of sewage sludge compost is not recommended.

Sewage sludge compost used in the production of zoysia grass had beneficial effects and the use of SSC in zoysia grass sod production can substitute urea fertilization.

\section{ACKNOWLEDGEMENTS}

This study was supported by the Coordination for the Improvement of Higher Education Personnel (CAPES, Brazil). We would also like to thank the company Tera Ambiental for financing the project.

\section{REFERENCES}

ANGLE, J. S.; WOLF, D. C.; HALL, J. R. Turfgrass growth aided by sludge compost. BioCycle, v. 22, p. 40-43, 1981.

BACKES, C.; SANTOS, A. J. M.; GODOY, L. J. G.; VILLAS BÔAS, R. L.; OLIVEIRA, M. R.; OLIVEIRA, F. C. Doses de lodo de esgoto compostado em produção de tapete de grama esmeralda imperial. Revista Brasileira de Ciência do Solo, v. 37, n. 5, p. 14021414, 2013. http://dx.doi.org/10.1590/S0100-06832013000500029

BACKES, C.; BÔAS, V.; LYRA, R.; LIMA, C. P. D.; GODOY, L. J. G. D.; BÜLL, L. T. et al. Leaf nitrogen nutritional status of zoysia grass evaluated by nitrogen concentration, chlorophyll meter and digital image, in sewage sludge fertilized areas. Bragantia, v. 69, n. 3, p. 661-668, 2010. http://dx.doi.org/10.1590/S0006-87052010000300018

BACKES, C.; BULL, L.T.; GODOY, L. J. G.; VILLAS BÔAS, R. L.; LIMA, C. P.; PIRES, E. C. Uso de lodo de esgoto na produção de tapetes de grama esmeralda. Ciência Rural, v. 39, p. 1045-1050, 2009. http://dx.doi.org/10.1590/S0103-84782009000400014 
BEARD, J. B. Turfgrass: science and culture. Englewood Cliffs: Prentice-Hall, 1973. 235 p.

CARVAlHO, M. A. C. de; FURLANI JUNIOR, E.; ARF, O.; SÁ, M. E.; PAULINO, H. B.; BUZETTI, S. Doses e épocas de aplicação de nitrogênio e teores foliares deste nutriente e de clorofila em feijoeiro. Revista Brasileira de Ciência do Solo, v. 27, p. 445-450, 2003. https://doi.org/10.1590/S0100-06832003000300006

CHRISTIANS, N. E. Fundamental of turfgrass management. Chelsea: Arbor Press, 1998. $301 \mathrm{p}$.

CONSELHO NACIONAL DO MEIO AMBIENTE - CONAMA (Brasil). Resolução n. 375, de 29 de agosto de 2006. Diário Oficial [da] União, seção 1, 30 agosto 2006.

CORRADI, I. C.; DE MATOS, A. T.; DE MATOS, M. P.; BORGES, A. C.; AQUINO, J. M. G. L. Degradação do lodo de esgoto sanitário compostado quando disposto no solo. Engenharia Agrícola, v. 36, n. 5, 2016.

CUNHA, A. R.; MARTINS, D. Classificação climática para os municípios de Botucatu e São $\begin{array}{llllllll}\text { Manuel, SP. Irriga, } & \text { v. } 14, \quad \text { n. } & 1, & \text { p. } & 1-11,\end{array}$ https://doi.org/10.15809/irriga.2009v14n1p1-11

DE MARIA, I. C.; KOCSSI, M. A.; DECHEN, S. C. F. Agregação do solo em área que recebeu lodo de Esgoto. Bragantia, v. 66, n. 2, p. 291-298, 2007.

EMBRAPA. Centro Nacional de Pesquisa de Solos-CNPS. Sistema brasileiro de classificação de solos. Brasília: Embrapa-SPI; Rio de Janeiro: Embrapa-CNPS, 2006. 306 p.

GODOY, L. J. G. et al. Doses de nitrogênio e potássio na produção de grama esmeralda. Ciência e Agrotecnologia, v. 31, n. 5, p. 1326-1332, 2007.

GRAMA LEGAL NATIONAL ASSOCIATION. Produção de grama. 2017. Available in: http//www.gramalegal.com. Access: March 10, 2018.

GRIFFITH, S.; BERO, N.; STIER, J.; OBEAR, G.; RUIS, S.; SOLDAT, D. Biosolids as an Alternative Fertilizer for Kentucky Bluegrass Sod Production in Wisconsin. Crop $\begin{array}{llllll}\text { Science, } & \text { v. } & 57, & \text { Suppl1, } & \text { p. } & \text { S-227-S-237, }\end{array}$ http://dx.doi.org/10.2135/cropsci2016.05.0367

GURGEL, R. A. G. Principais espécies e variedades de grama. In: SIMPOSIO SOBRE GRAMADOS, 1., 2003, Botucatu. Produção, implantação e manutenção: anais[...] Botucatu: UNESP, Faculdade de Ciências Agronômicas, 2003.

KIEHL, E. J. Fertilizantes orgânicos. Piracicaba: Ceres,1985. 492 p.

LI, D.; FANG, W.; HAN, L. Nitrogen fertilization influences shear strength and quality of Kentucky bluegrass sod grown on clay. Agronomy Journal, v. 103, p. 751-755, 2011. http://dx.doi.org/10.2134/agronj2010.0470

MALAVOLTA, E.; VITTI, G. C.; OLIVEIRA, S. A. Avaliação do estado nutricional das plantas: princípios e aplicações. 2. ed. Piracicaba: POTAFOS, 1997. 317p.

MEHROTRA, A.; KUNDU, K.; SREEKRISHNAN, T. R. Decontamination of heavy metal laden sewage sludge with simultaneous solids reduction using thermophilic sulfur and ferrous oxidizing species. Journal of Environmental Management, v. 167, p. 228-235, 2016. https://doi.org/10.1016/j.jenvman.2015.11.004 
MILLS, H. A.; JONES, J. B. Jr. Plant analysis handbook II: a practical sampling, preparation, analysis and interpretation guide. Athens: MicroMacro, 1996. $456 \mathrm{p}$.

PAREDES FILHO, M. V. Compostagem de lodo de esgoto para uso agrícola. Revista Agroambiental, v. 3, n. 3, p.73-80, 2011.

PETERSON, K.; SHONKWILER ARNOLD, K.; BREMER, D. Custom Light Box for Digital Image Turfgrass Analysis. K- State Turfgrass Research Report of Progress 1035, p. 89-91, 2011.

RASHAD, F. M.; SALEH, W. D.; MOSELHY, M. A. Bioconversion of rice straw and certain agro-industrial wastes to amendments for organic farming systems: 1. Composting, quality, stability and maturity indices. Bioresource Technology, v. 101, n. 15, p. 59525960, 2010. https://doi.org/10.1016/j.biortech.2010.02.103

SCHNELL, R.W.; VIETOR, D. M.; WHITE, R. H.; PROVIN, T. L.; MUNSTER, C. L. Effects of composted biosolids and nitrogen on turfgrass establishment, sod properties, and nutrient export at harvest. HortScience, v. 44, p. 1746 -1750, 2009.

SINGH, R. P.; AGRAWAL, M. Potential benefits and risks of land application of sewage $\begin{array}{llllll}\text { sludge. Waste } & \text { Management, v. 28, p. 347-358, } 2008 .\end{array}$ https://doi.org/10.1016/j.wasman.2006.12.010

SINGH, R. P.; AGRAWAL, M. Use of sewage sludge as fertilizer supplement for Abelmoschus esculentus plants: physiological, biochemical and growth responses. International Journal of Environment and Waste Management, v. 3, p. 91-106, 2009.

TESFAMARIAM, T. H.; ANNANDALE, J. G.; STEYN, J. M.; STIRZAKER, M. J. Exporting large volumes of municipal sewage sludge through turfgrass sod production. Journal of $\begin{array}{llllll}\text { Environmental Quality, } & \text { v. } & 38, & \text { p. }\end{array}$ http://dx.di.org/10.2134/jeq2008.0397

TESTER, C. F. Tall fescue growth in greenhouse, growth chamber, and field plots amended with sludge compost and fertilizer. Soil Science, v. 148, p. 452-458, 1989.

TURFGRASS PRODUCERS INTERNATIONAL. Turfgrass: functional, recreational e aesthetic. Turf Resource Center, 2002. Available in: http//www.turfgrass sod.org/trc/statistics.html. Access: March 10, 2018. 